\title{
Low-Flow Characteristics and Discharge Profiles for Selected Streams in the Neuse River Basin, North Carolina
}

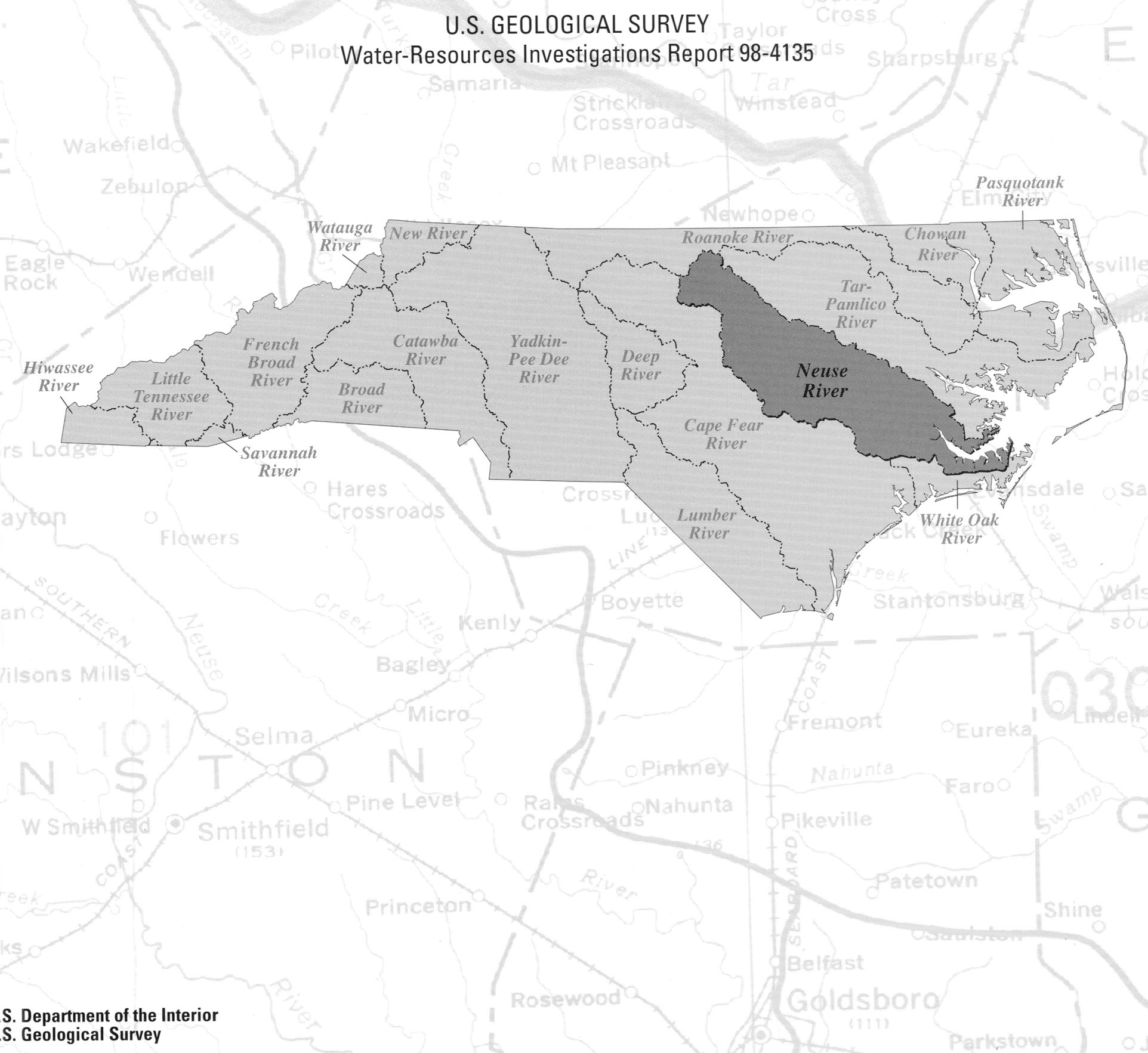




\section{GLOSSARY}

Base flow. The contribution of flow to a stream from ground water or spring discharge.

Climatic year. A continuous 12-month period during which a complete annual cycle occurs. In low-flow analyses in North Carolina, the climatic year typically is from April 1 through March 31, designated by the calendar year in which the climatic year begins. For example, the 1996 climatic year is the period from April 1, 1996, to March 31, 1997. The year begins and ends during the period of increased flows so that all flows during a single dry season are included in annual values for that year.

Continuous-record gaging station. A site on a stream where continuous records of gage height are collected and for which discharge records are computed.

Drainage area. The drainage area of a stream at a specified location is that area, measured in a horizontal plane, which is enclosed by a drainage divide.

Gage height. The water-surface elevation referenced to an arbitrary gage datum, often used interchangeably with the term "stage."

Low flow. Base flow or sustained fair-weather flow.

Partial-record measuring site. A site on a stream where periodic discharge measurements are collected, usually for a period of years. The data collected at partial-record sites are often correlated with data at nearby continuousrecord gaging stations to estimate low-flow characteristics at the partialrecord sites.

Recurrence interval. The average interval of time within which the magnitude of an extreme event can be expected to be equaled or exceeded once. The primary recurrence intervals used in this report are 2 years and 10 years. For example, if the 7-day, 10-year low-flow discharge is 5 cubic feet per second $\left(\mathrm{ft}^{3} / \mathrm{s}\right)$, then the annual minimum average discharge for a 7 -consecutive-day period would be $5 \mathrm{ft}^{3} / \mathrm{s}$ or lower, on average, 1 time in 10 years, 5 times in 50 years, or 10 times in 100 years. While recurrence intervals indicate the frequency of occurrence for a particular hydrologic event, it should be noted that the event could occur more than once in a given year, in consecutive years, or not at all during the period specified by the recurrence interval.

Unit flow. Value of flow expressed in units of volume per time per square-mile drainage area. In this report, unit flow is expressed as cubic feet per second per square mile $\left[\left(\mathrm{ft}^{3} / \mathrm{s}\right) / \mathrm{mi}^{2}\right]$.

Water year. The 12-month period October 1 through September 30, designated by the calendar year in which the period ends. For example, the 1996 water year is the period from October 1, 1995, to September 30, 1996. Average discharge and flow-duration data are computed using the water-year time frame.

Zero-flow day. Day in which no flow occurred at a continuous-record gaging station as evidenced by a daily mean discharge of zero. 


\section{Low-flow Characteristics and Discharge Profiles for Selected Streams in the Neuse River Basin, North Carolina}

By J. Curtis Weaver

\section{U.S. GEOLOGICAL SURVEY}

Water-Resources Investigations Report 98-4135

Prepared in cooperation with the

Division of Water Quality of the North Carolina Department of Environment and Natural Resources

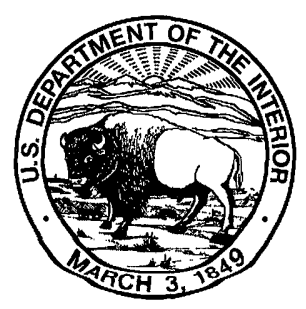




\section{U.S. DEPARTMENT OF THE INTERIOR \\ BRUCE BABBITT, Secretary}

U.S. GEOLOGICAL SURVEY

Thomas J. Casadevall, Acting Director

The use of firm, trade, and brand names in this report is for identification purposes only and does not constitute endorsement by the U.S. Government.

For additional information write to:

District Chief

U.S. Geological Survey

3916 Sunset Ridge Road

Raleigh, NC 27607-6416
Copies of this report can be purchased from:

U.S. Geological Survey

Branch of Information Services

Box 25286, Federal Center

Denver, CO 80225-0286 


\section{CONTENTS}

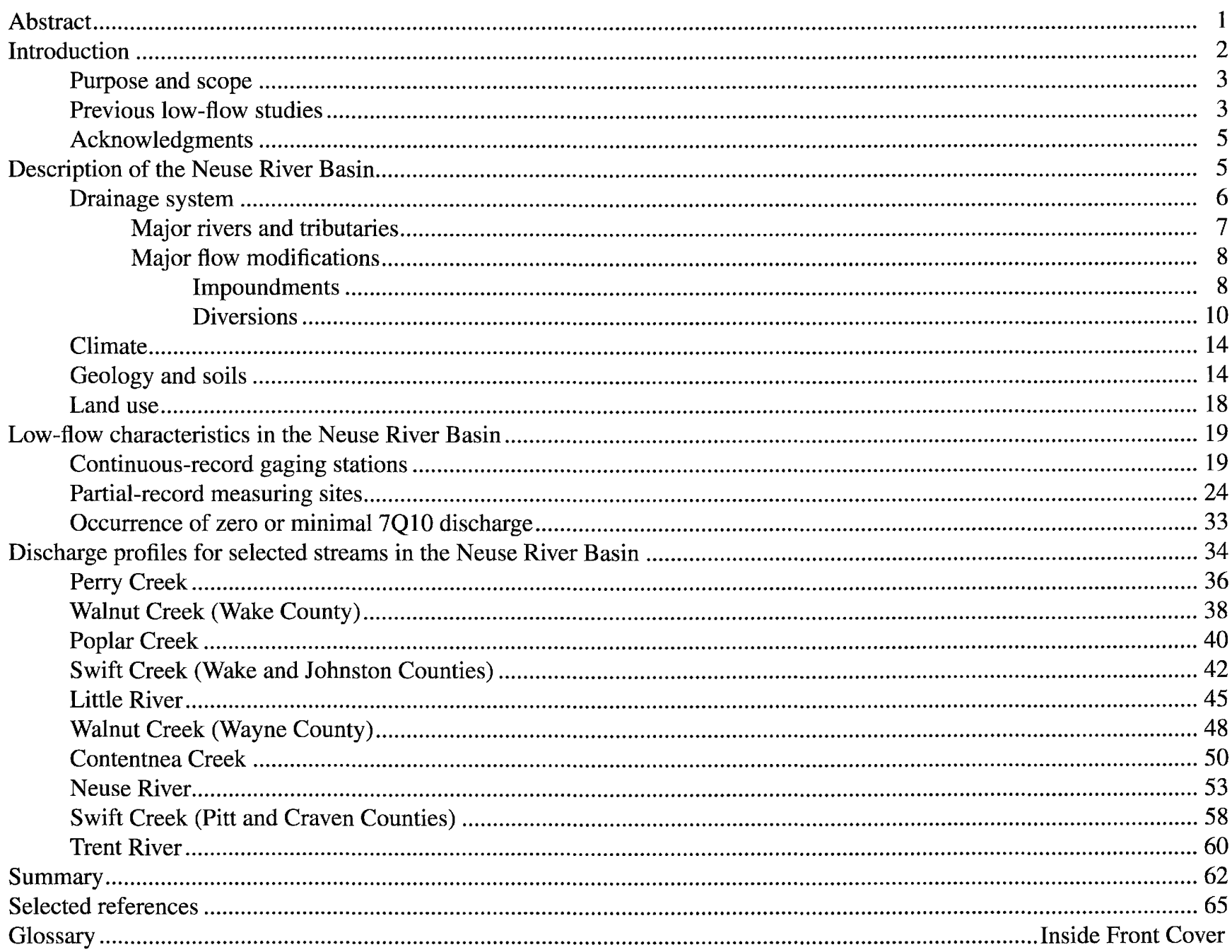

\section{PLATE}

1. Map showing continuous-record gaging stations and partial-record measuring sites, profiled streams, and occurrence of zero- or minimal-7Q10 discharges in the Neuse River Basin in North Carolina In Pocket

\section{FIGURES}

1-2. Maps showing:

1. Locations of major river basins, the Neuse River Basin, and physiographic provinces

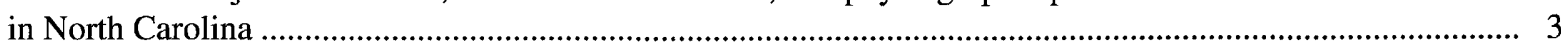

2. Hydrologic areas of similar potential to sustain low flows in North Carolina...............................................

3. Graph showing flow-duration curves for the Little River near Orange Factory (site 51) and Nahunta Swamp near Shine (site 432)

4-6. Maps showing:

4. Hydrologic units in the Neuse River Basin, North Carolina.................................................................

5. Average annual (A) temperature and (B) precipitation in the Neuse River Basin, 1961-90............................ 15

6. (A) Geology and (B) soil hydrologic groups in the Neuse River Basin, North Carolina ................................. 16 
7-19. Graphs showing:

7. Low-flow frequency curve of annual minimum 7-day discharges using log-Pearson Type III frequency distribution at Middle Creek near Clayton (site 284)

8. Correlation of concurrent discharge at partial-record site at Mill Creek near Cox Mill (site 307) and at the index site at Little Coharie Creek near Roseboro (Cape Fear River Basin)

9.-18. Relation of river miles to (A) drainage area and (B) low-flow discharges for:

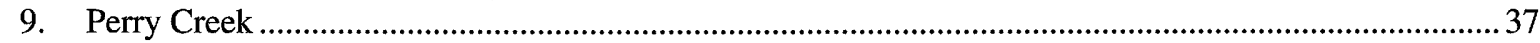

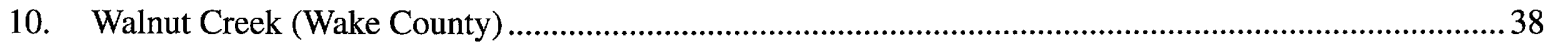

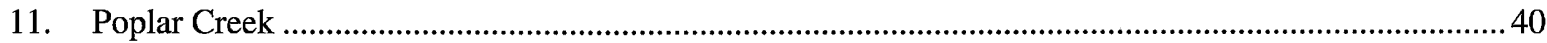

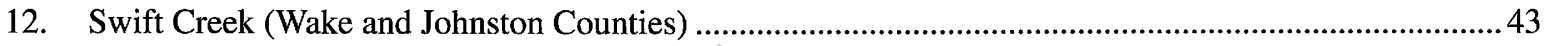

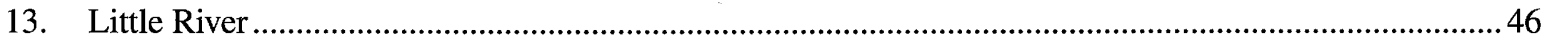

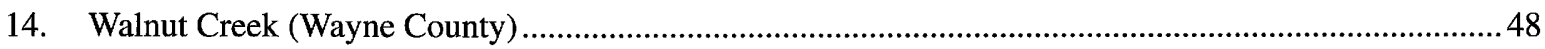

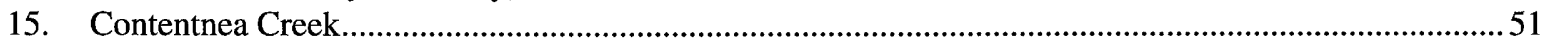

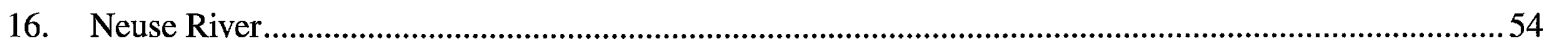

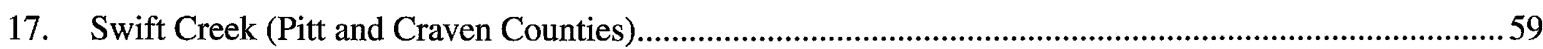

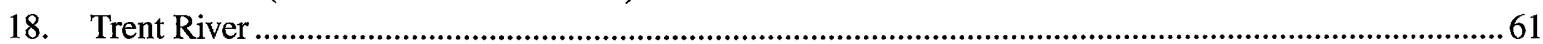

\section{TABLES}

1. Code, name, and drainage area of USGS hydrologic units in the Neuse River Basin, North Carolina

2. Summary of selected flow modifications by surface-water withdrawals and point-source discharges to streams in the Neuse River Basin, 1996.

3. Soil hydrologic groups in the Neuse River Basin, North Carolina ...................................................................17

4. Areas and percentages of land-use categories in the Neuse River Basin, North Carolina ............................................. 18

5. Summary of continuous-record gaging stations and partial-record measuring sites in the Neuse River Basin in North Carolina where records of gage height and streamflow were collected.

6-7. Magnitude and frequency of annual low-flow characteristics at selected:

6. Continuous-record gaging stations in the Neuse River Basin, North Carolina ...................................................20

7. Partial-record measuring sites in the Neuse River Basin, North Carolina .........................................................25

8. Low-flow characteristics for partial-record measuring sites and regional equations in Hydrologic Area 5 within the Neuse River Basin, North Carolina 
CONVERSION FACTORS, TEMPERATURE, VERTICAL DATUM, AND ACRONYMS

\begin{tabular}{|c|c|c|}
\hline Multiply & By & To obtain \\
\hline \multicolumn{3}{|c|}{ Length } \\
\hline inch (in.) & 25.4 & millimeter \\
\hline foot (ft) & 0.3048 & meter \\
\hline mile $(\mathrm{mi})$ & 1.609 & kilometer \\
\hline \multicolumn{3}{|c|}{ Area } \\
\hline acre & 4,047 & square meter \\
\hline acre & 0.4047 & hectare \\
\hline square mile $\left(\mathrm{mi}^{2}\right)$ & 2.590 & square kilometer \\
\hline \multicolumn{3}{|c|}{ Flow } \\
\hline gallon per minute (gal/min) & 0.06309 & liter per second \\
\hline million gallons per day (Mgal/d) & 0.04381 & cubic meter per second \\
\hline cubic foot per second $\left(\mathrm{ft}^{3} / \mathrm{s}\right)$ & 0.02832 & cubic meter per second \\
\hline $\begin{array}{l}\text { cubic foot per second per square mile } \\
\qquad\left[\left(\mathrm{ft}^{3} / \mathrm{s}\right) / \mathrm{mi}^{2}\right]\end{array}$ & 0.01093 & cubic meter per second per square kilometer \\
\hline
\end{tabular}

Temperature: In this report, temperature is given in degrees Fahrenheit $\left({ }^{\circ} \mathrm{F}\right)$, which can be converted to degrees Celsius $\left({ }^{\circ} \mathrm{C}\right)$ by using the following equation:

$$
{ }^{\circ} \mathrm{C}=5 / 9\left({ }^{\circ} \mathrm{F}-32\right)
$$

Sea level: In this report, "sea level" refers to the National Geodetic Vertical Datum of 1929 (NGVD of 1929)—a geodetic datum derived from a general adjustment of the first-order level nets of both the United States and Canada, formerly called Sea Level Datum of 1929.

\section{Acronyms:}

$\begin{array}{ll}\text { DWQ } & \text { Division of Water Quality } \\ \text { GIRAS } & \text { geographic information retrieval and analysis system } \\ \text { GIS } & \text { geographic information system } \\ \text { HA } & \text { hydrologic area } \\ \text { MOVE. } 1 & \text { Maintenance of Variance Extension } \\ \text { NPDES } & \text { National Pollution Discharge Elimination System } \\ \text { TM } & \text { Thematic Mapper } \\ \text { USEPA } & \text { U.S. Environmental Protection Agency } \\ \text { USGS } & \text { U.S. Geological Survey }\end{array}$





\title{
Low-Flow Characteristics and Discharge Profiles for Selected Streams in the Neuse River Basin, North Carolina
}

\author{
By J. Curtis Weaver
}

\section{ABSTRACT}

An understanding of the magnitude and frequency of low-flow discharges is an important part of evaluating surface-water resources and planning for municipal and industrial economic expansion. Low-flow characteristics are summarized in this report for 50 continuousrecord gaging stations and 113 partial-record measuring sites in the Neuse River Basin in North Carolina. Records of discharge collected through the 1996 water year were used in the analyses. Flow characteristics included in the summary are (1) average annual unit flow; (2) 7Q10 low-flow discharge, the minimum average discharge for a 7-consecutive-day period occurring, on average, once in 10 years; (3) 30Q2 low-flow discharge; (4) W7Q10 low-flow discharge, similar to 7Q10 discharge except that only flow during November through March is considered; and (5) 7Q2 lowflow discharge.

The potential for sustained base flows is relatively low in the upper and lower ends of the Neuse River Basin compared to the central part of the basin. Most soils in the upper part of the basin are derived from rocks of the Triassic basin.

Typically, these soils tend to be poorly drained due to the presence of clay, which combined with the lower average rainfall amounts in the basin limits the infiltration of water to surficial aquifers for release as sustained base flow during drought conditions. Among sites in the upper part of the basin having zero 7Q10 discharges, the drainage areas range from less than 0.01 to about 44 square miles. For sites in this area having non-zero 7Q10 discharges, the average 7Q10 unit low flow is about 0.005 cubic foot per second per square mile. Therefore, sites with drainage areas less than about 10 square miles could be expected to have zero or minimal 7Q10 discharges (less than 0.05 cubic foot per second).

In the lower part of the basin, the presence of poorly drained soils in combination with land slopes having little or no relief also serves to limit the potential for sustained base flows. On tributaries that drain to the Neuse River downstream from its confluence with Contentnea Creek, eight sites having drainage areas ranging from 2.5 to 27 square miles were determined to have zero 7Q10 discharges. For sites in this area having non-zero 7Q10 discharges, the average 7Q10 unit low flow is about 0.01 cubic foot per second per square mile. Therefore, sites with drainage areas less than about 5 square miles could be expected to have zero or minimal 7Q10 discharges (less than 0.05 cubic foot per second).

In the central part of the basin where moderately and well-drained soils are predominant, sites having 7Q10 discharges of zero were noted on a more widespread basis and across a large range in drainage area. Drainage areas ranged from about 1 to nearly 82 square miles. Where the predominant factor at sites in the upper and lower ends of the study area is poorly drained soils, the magnitudes of low flows in the central section appear to be affected by a combination of factors that include soils, degree of terrain slope, and drainage area. 
Drainage area and low-flow discharge profiles are presented for 10 streams in the Neuse River Basin; these profiles reflect a wide range in subbasin size, characteristics, and streamflow conditions. The selected streams are Perry Creek, Walnut Creek (Wake County), Poplar Creek, Swift Creek (Wake and Johnston Counties), Little River, Walnut Creek (Wayne County), Contentnea Creek, the Neuse River, Swift Creek (Pitt and Craven Counties), and the Trent River. The drainage-area profiles show downstream increases in basin size. At the mouths of streams profiled, the drainage areas range from 9 square miles to about 5,600 square miles. Low-flow discharge profiles for each stream include 7Q10, 30Q2, W7Q10, and 7Q2 discharges with contributions from major tributaries included. In the lower reaches of the Neuse River and Swift Creek (Pitt and Craven Counties) as well as much of the Trent River, lowflow discharges consist of ground-water discharge from the Castle Hayne aquifer, the most productive of the 10 aquifers in North Carolina in terms of yield, a factor attributed to the extensive occurrence of porous limestone in the aquifer.

\section{INTRODUCTION}

The need for a better understanding of low-flow hydrology and for improved techniques in determining low-flow characteristics of streams has become more critical as demands for sustained, high-quality water supplies and effective waste assimilation have increased. The simultaneous occurrence of these higher demands and recent droughts in North Carolina have increased awareness of the importance of determining low-flow characteristics.

Low flow, also referred to as base flow or sustained fair-weather flow, is composed largely of ground-water discharge from aquifers into streams. Discharges from aquifers have large spatial and temporal variations that are highly dependent on topographic, geologic, and climatic conditions in a drainage basin. The high variability of such conditions across North Carolina-and sometimes even within a drainage basin or along the same stream-results in a complex low-flow hydrology. Moreover, the characterization of low-flow hydrology is further complicated by withdrawals, point-source discharges, impoundments, and development within the drainage basin. Low flows in North Carolina typically occur at the conclusion of the growing season in late summer and early autumn, following maximum use of ground water by crops and other plants. Additionally, higher temperatures during the summer and early autumn seasons cause increased human consumption of water which, in turn, causes a higher demand for withdrawals from streams and reservoirs.

An understanding of low-flow characteristics is crucial in the evaluation of water-supply potential and reservoir-release requirements, the determination of wastewater discharges to streams, and the maintenance of aquatic habitats in streams. Where sufficient records of discharge are available at continuous- and partialrecord sites, application of statistical techniques, such as those described by Riggs (1972), forms the basis for determining low-flow characteristics. However, the number of sites for which sufficient record exists to determine low-flow characteristics is far outnumbered by those locations where little or no record is available for developing low-flow estimates.

Low-flow characteristics are defined by a set of statistically derived discharge values having an associated duration and recurrence interval (or probability of occurrence). For example, the 7-day, 10-year low-flow discharge (hereafter referred to as $7 \mathrm{Q} 10$ discharge) is the annual lowest mean streamflow over a 7-consecutive-day period which, on average, will be exceeded in 9 out of 10 years. Stated another way, the probability is 10 percent (the inverse of the recurrence interval) that the lowest average 7-consecutive-day flow in any year will be less than the 7Q10 discharge (Giese and Mason, 1993). If the 7Q10 discharge is 5 cubic feet per second $\left(\mathrm{ft}^{3} / \mathrm{s}\right)$, then the annual minimum average discharge for a 7-consecutive-day period would be $5 \mathrm{ft}^{3} / \mathrm{s}$ or lower, on average, 1 time in 10 years, 5 times in 50 years, or 10 times in 100 years.

In North Carolina, other low-flow statistics used by State regulatory agencies in determining permitting limits for withdrawals from and discharges to streams include the 30Q2, W7Q10, and 7Q2 discharges. The W7Q10 discharge, or "winter 7Q10," is defined in a similar manner as the 7Q10 discharge except that only flow during the months of November through March is considered in the analysis.

In 1991, the Division of Water Quality (DWQ, formerly the Division of Environmental Management) of the North Carolina Department of Environment and 
Natural Resources, began using a basinwide approach in its assessment and management of water quality and, in particular, permitting of point-source discharges.

This approach is being applied sequentially to each of the 17 major river basins in the State (fig. 1) so that all point-source discharges in a basin are permitted simultaneously. The process is repeated for each basin at 5-year intervals. In conjunction with the basinwide approach, the U.S. Geological Survey (USGS), in cooperation with the DWQ, has conducted studies to define low-flow characteristics and develop flow profiles for selected streams in a number of river basins (Weaver, 1996, 1997).

\section{Purpose and Scope}

This report presents low-flow characteristics for streams in the Neuse River Basin in North Carolina. Low-flow characteristics at existing stream-gaging stations are summarized, and drainage area and lowflow discharge profiles for selected streams in the Neuse River Basin are presented. Descriptions of a number of basin characteristics, such as impoundments, flow diversions, climate, geology, soils, and land use, are included along with a discussion of their effects on low flows.

Low-flow characteristics are summarized for 50 continuous-record gaging stations and for 113 partialrecord measuring sites; statistics include the average annual unit flow and the 7Q10, 30Q2, W7Q10, and
7Q2 discharges. Although the period of record varies from site to site, records of discharge collected through the 1996 water year were used in the analyses for this report. The number of zero-flow days and discharge measurements for continuous- and partial-record sites, respectively, also are included.

Drainage area and low-flow discharge profiles are presented for 10 selected streams in the Neuse River Basin. The 10 streams were identified by DWQ from a list of streams that were prioritized on the basis of water-quality issues being addressed as well as basin characteristics being represented. The streams drain areas that reflect a wide range of basin size, characteristics, and streamflow conditions. The selected streams include Perry Creek, Walnut Creek (Wake County), Poplar Creek, Swift Creek (Wake and Johnston Counties), Little River, Walnut Creek (Wayne County), Contentnea Creek, the Neuse River, Swift Creek (Pitt and Craven Counties), and the Trent River. Discharge profiles show the relation of 7Q10,30Q2, W7Q10, and 7Q2 discharges to river mileage for the streams.

\section{Previous Low-flow Studies}

Prior to World War II, low-flow characteristics of North Carolina streams were determined only for sites operated as continuous-record gaging stations. With the economic expansion after World War II, the USGS began to receive an increasing number of requests for

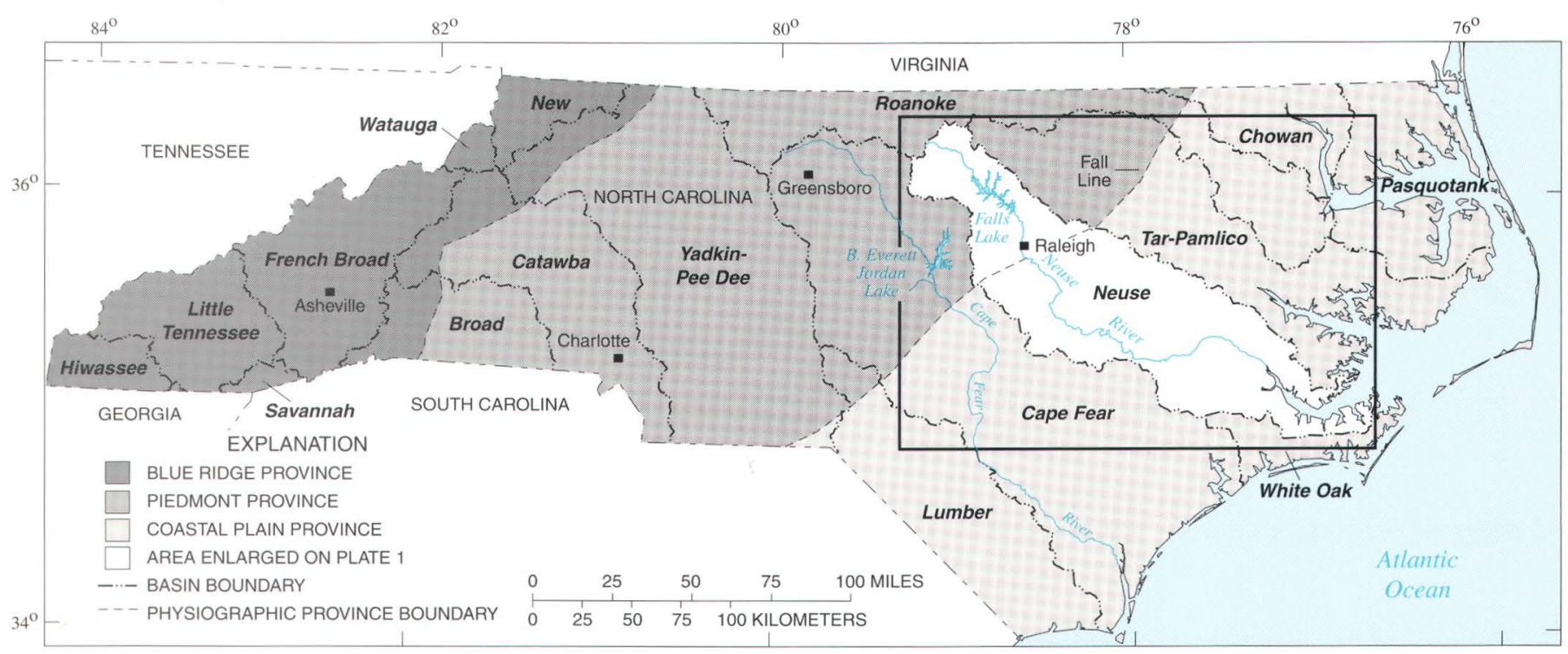

Figure 1. Locations of major river basins, the Neuse River Basin, and physiographic provinces in North Carolina. 
hydrologic information for sites where no data previously had been collected (Yonts, 1971). Thus, the USGS expanded its data-collection program in the late 1940 's to include partial-record measuring sites where discharge measurements were made on a periodic basis. Discharge measurements made under base-flow conditions along with observations of zero flow became the foundation of data used in the initial assessments of low-flow characteristics of streams in North Carolina. With data available from the network of partial-record measuring sites, the USGS began to respond to requests for low-flow characteristics on a site-specific basis, including those for ungaged sites.

Estimates of low-flow discharges continue to be provided, upon request, to other government agencies and private corporations. These estimates are used in assessing the capacity of streams to receive wastewater discharges and to provide withdrawals for water supply. Estimates generally are provided on a sitespecific basis with little consideration of previously determined low-flow statistics upstream or downstream from the site identified in the request. In some instances, for a given stream, this has led to inconsistencies in estimates of low-flow discharges for adjacent sites.
A limited number of studies have been conducted to investigate low flows for streams in North Carolina. Goddard (1963) presented low-flow characteristics for many continuous-record gaging stations in North Carolina, along with drainage area and 7Q10 discharge profiles developed for selected mainstem rivers. Yonts (1971) reported base-flow measurements made at over 2,200 continuous-record gaging stations and partial-record measuring sites throughout the State.

Giese and Mason (1993) evaluated low-flow characteristics at 122 continuous-record gaging stations and 396 partial-record measuring sites with drainage areas between 1 and 400 square miles $\left(\mathrm{mi}^{2}\right)$ and streamflows unaffected by regulation or diversions. Sites were characterized on the basis of similarity in their ranges of low-flow discharges and potential to sustain base flow. Ten hydrologic areas (HA's) were delineated, and regression equations, which related low flows to basin characteristics, were derived to determine flow characteristics at ungaged sites (fig. 2). Equations for only 4 of the 10 areas-HA10, representing the mountains and western Piedmont; HA3, the Sand Hills; and HA5 and HA9, the eastern and central Piedmont, respectively — had standard

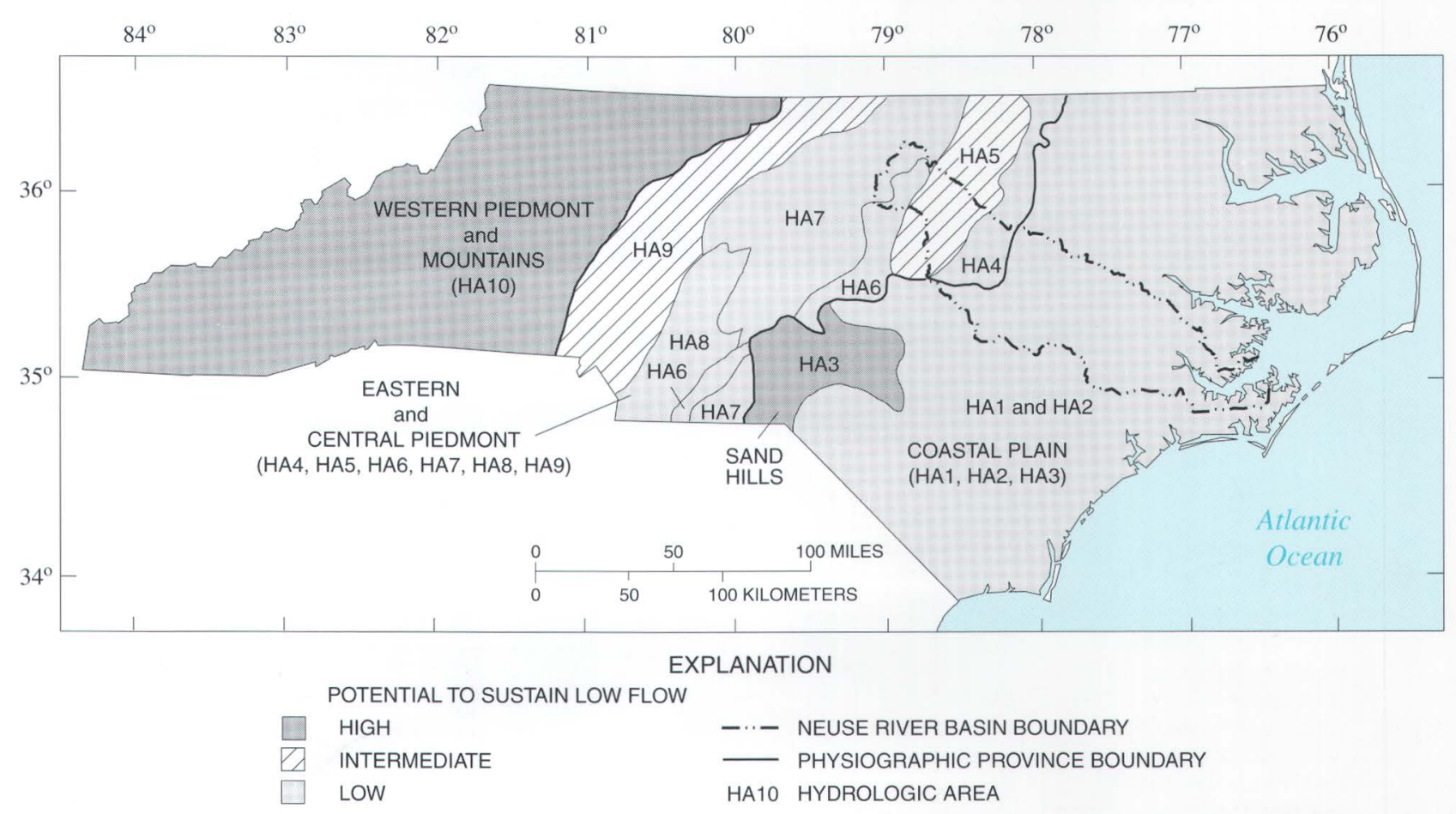

Figure 2. Hydrologic areas (HA's) of similar potential to sustain low flows in North Carolina (modified from Giese and Mason, 1993). 
errors that were considered small enough to permit use of the equations in estimating low-flow characteristics at the ungaged sites. The large standard errors computed for equations in the remaining HA's reflect the complex relation between low-flow hydrology and geologic, topographic, and climatic factors. High standard errors for low-flow regression equations also were reported in a 1970 comprehensive study of low flows in which 47 USGS Districts participated (each District representing the State in which it is located) (Riggs, 1973). Some Districts reported standard errors well in excess of 100 percent, and others were unable to derive useful low-flow relations.

Evett (1994) investigated the effects of urbanization and land-use changes on low flows. Negative trends in low flows were detected from data at selected continuous-record gaging stations in the Asheville, Charlotte, Greensboro, and Raleigh municipalities (fig. 1) as well as gaging stations in nearby rural areas. While the conclusions tended to support the investigation's hypothesis of decreasing low flows with increasing urbanization, Evett (1994) described the results as being statistically inconclusive.

Weaver (1996) conducted a study of low-flow characteristics in the Roanoke River Basin as part of the DWQ's program of basinwide assessment and management of water quality in major river basins in North Carolina. Low-flow characteristics were summarized for 82 streamflow sites in North Carolina (79 sites) and Virginia (3 sites), and profiles of drainage area and low-flow discharge were developed for 10 selected streams that vary widely in basin size, characteristics, and streamflow conditions. The streams included were Town Fork Creek, Hogans Creek, Mayo River, Buffalo Creek, Smith River, Country Line Creek, Dan River, Marlowe Creek, Hyco River, and Roanoke River. Drainage-area profiles show increases in drainage areas as streams travel their course within the basin. At the mouths, drainage areas for profiled streams range from $22 \mathrm{mi}^{2}$ to about $9,700 \mathrm{mi}^{2}$. Lowflow discharges for each stream include 7Q10, 30Q2, W7Q10, and 7Q2 discharges in a continuous profile, and contributions from major tributaries also are included.

Weaver (1997) also investigated low-flow characteristics in the Deep River Basin in the central Piedmont Province of North Carolina. The Deep River drains slightly more than $1,440 \mathrm{mi}^{2}$ and is tributary to the Cape Fear River, a major river whose basin is located immediately south of the Neuse River Basin (fig. 1). Low-flow characteristics were summarized for 7 continuous-record gaging stations and 23 partialrecord measuring sites. Drainage-area and low-flow discharge profiles were developed for the Deep River and are presented in a similar manner to those for the Roanoke River Basin (Weaver, 1996). The methods used for this study are the same as those previously used by Weaver $(1996,1997)$, and the presentation of results is similar to the previous presentation of results for the Roanoke and Deep Rivers.

\section{Acknowledgments}

The author acknowledges the staffs of the North Carolina Divisions of Water Quality and Water Resources for their assistance in compiling information about point-source discharge permits, water withdrawals, and impoundments. Likewise, additional information concerning flow diversions provided by many superintendents and operators at local watertreatment plants, as well as wastewater-treatment facilities in the Neuse River Basin, was helpful in the assessment of flow modifications on low-flow characteristics.

Finally, the author gratefully acknowledges the contributions of Mr. Steve Carlson and Mr. Gerald Strickland, of the U.S. Geological Survey, to the investigation of low-flow characteristics in the Neuse River Basin. Mr. Carlson's research into and efforts in compiling information about the geology and soils in the basin are the basis of much of the discussion on this subject. Mr. Strickland's development of the drainagearea profiles presented in this report are the foundation of the corresponding low-flow discharge profiles developed by the author.

\section{DESCRIPTION OF THE NEUSE RIVER BASIN}

The Neuse River Basin drains an area of about $5,600 \mathrm{mi}^{2}$ in parts of central eastern North Carolina (Seaber and others, 1987). The headwaters of the Neuse River begin in Orange and Person Counties, and the river flows in a general southeasterly direction through the Piedmont and Coastal Plain Provinces before entering the Pamlico Sound near Maw Point in Pamlico County (pl. 1). The nature of the drainage system within the Neuse River Basin varies greatly from the headwaters to the mouth. 
Ground elevations in the Neuse River Basin decrease from northwest to southeast. Average elevations range from approximately 650 to 800 feet (ft) above sea level along the basin boundary in Orange and Person Counties to near sea level at New Bern and points downstream. The highest elevation in the Neuse River Basin is nearly $900 \mathrm{ft}$ above sea level near the drainage area divide south of Roxboro in Person County (pl. 1).

The Neuse River Basin includes parts of 6 of the 10 hydrologic areas (HA's) identified by Giese and Mason (1993; fig. 2). The areas of the basin within the HA's delineated for the central and eastern Piedmont have varying levels of potential for sustaining base flow during droughts (fig. 2). Median 7Q10 discharges for streams in HA7, HA6, HA5, and HA4 are 0.005, 0.0, 0.065 , and 0.0 cubic feet per second per square mile $\left([\mathrm{ft} / \mathrm{s}] / \mathrm{mi}^{2}\right)$, respectively. Giese and Mason (1993) identified a correlation between the potential to sustain base flow and well yields reported by Daniel (1989), who related rock type to well yields. Thus, these HA's were delineated primarily on the basis of geology. The HA having the lowest potential for sustained base flow is HA6, defined by Giese and Mason (1993) as the Triassic basin HA. Numerous sites that lie within HA6 in the Neuse River Basin were determined to have no potential for sustained base flows. The eastern areas of the Neuse River Basin are in HA1 and HA2 in the Coastal Plain and have low potential to sustain base flow in streams. Median 7Q10 discharges for sites in HA's 1 and 2 are 0.0 and $0.006\left(\mathrm{ft}^{3} / \mathrm{s}\right) / \mathrm{mi}^{2}$, respectively (Giese and Mason, 1993). Low topographic relief results in low hydraulic gradients in the water table and provides little potential to move ground water toward streams.

The effects of geologic and climatic factors at sites having different sustained base flows can be seen in the flow-duration curves for two sites having identical drainage areas in the study area (fig. 3). Base flows for the gaging station at Nahunta Swamp near Shine (site 432, pl. 1) are higher than those at the gaging station on Little River near Orange Factory (site 51, pl. 1). During the 1962-96 water years, flows at site 432 were $6.5 \mathrm{ft}^{3} / \mathrm{s}$ or greater 95 percent of the time, whereas flows at site 51 were $1.5 \mathrm{ft}^{3} / \mathrm{s}$ or greater 95 percent of the time. Differences between base flows at the two sites increase as the exceedence level increases. Site 51 is located in HA7, the Carolina Slate Belt HA, which is characterized by the presence of metavolcanic and metaigneous rocks (Giese and

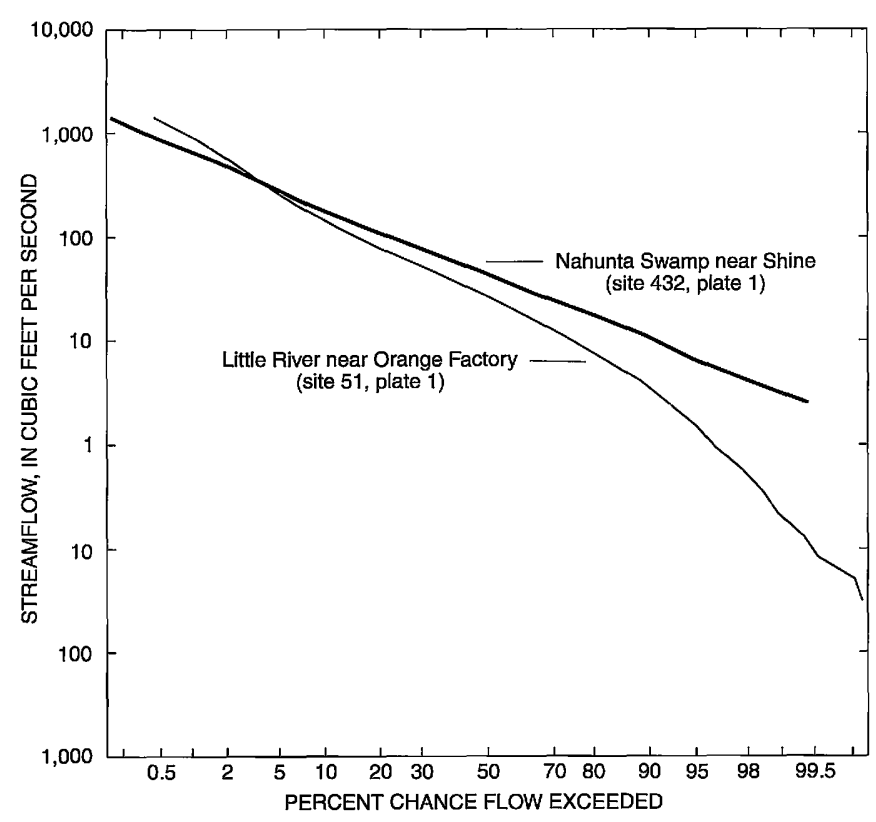

Figure 3. Flow-duration curves for the Little River near Orange Factory (site 51) and Nahunta Swamp near Shine (site 432).

Mason, 1993). These rocks are described as being among the lowest-yielding units and have low values (median 7Q10 discharge of $0.005\left[\mathrm{ft}^{3} / \mathrm{s}\right] / \mathrm{mi}^{2}$ ) for lowflow characteristics when compared to sites in other HA's. Site 432 is in HA1 (clay soils) and HA2 (sandy soils) where the geology is defined by alternating layers of sand, silt, clay, and limestone (Giese and Mason, 1993). Average annual rainfall amounts in the Nahunta Swamp Basin in Wayne and Greene Counties are approximately 4 inches (in.) greater than those in the Little River Basin in Orange and Durham Counties (pl. 1). The individual effects of geologic and climatic factors that contribute to the overall determination of base flows cannot be quantified separately at either site. However, the likely presence of sandy soils in combination with higher rainfall amounts apparently results in higher base flows at site 432 than at site 51 .

\section{Drainage System}

The Neuse River Basin consists of four subbasins, hydrologic units 03020201 to 03020204 , as defined in the USGS National Water Data Network system of hydrologic units (Seaber and others, 1987) (fig. 4; table 1). The cumulative drainage area of the four subbasins is about $5,600 \mathrm{mi}^{2}$, which differs from the nearly $6,200 \mathrm{mi}^{2}$ identified by the DWQ in their basinwide assessment of water quality (North Carolina 


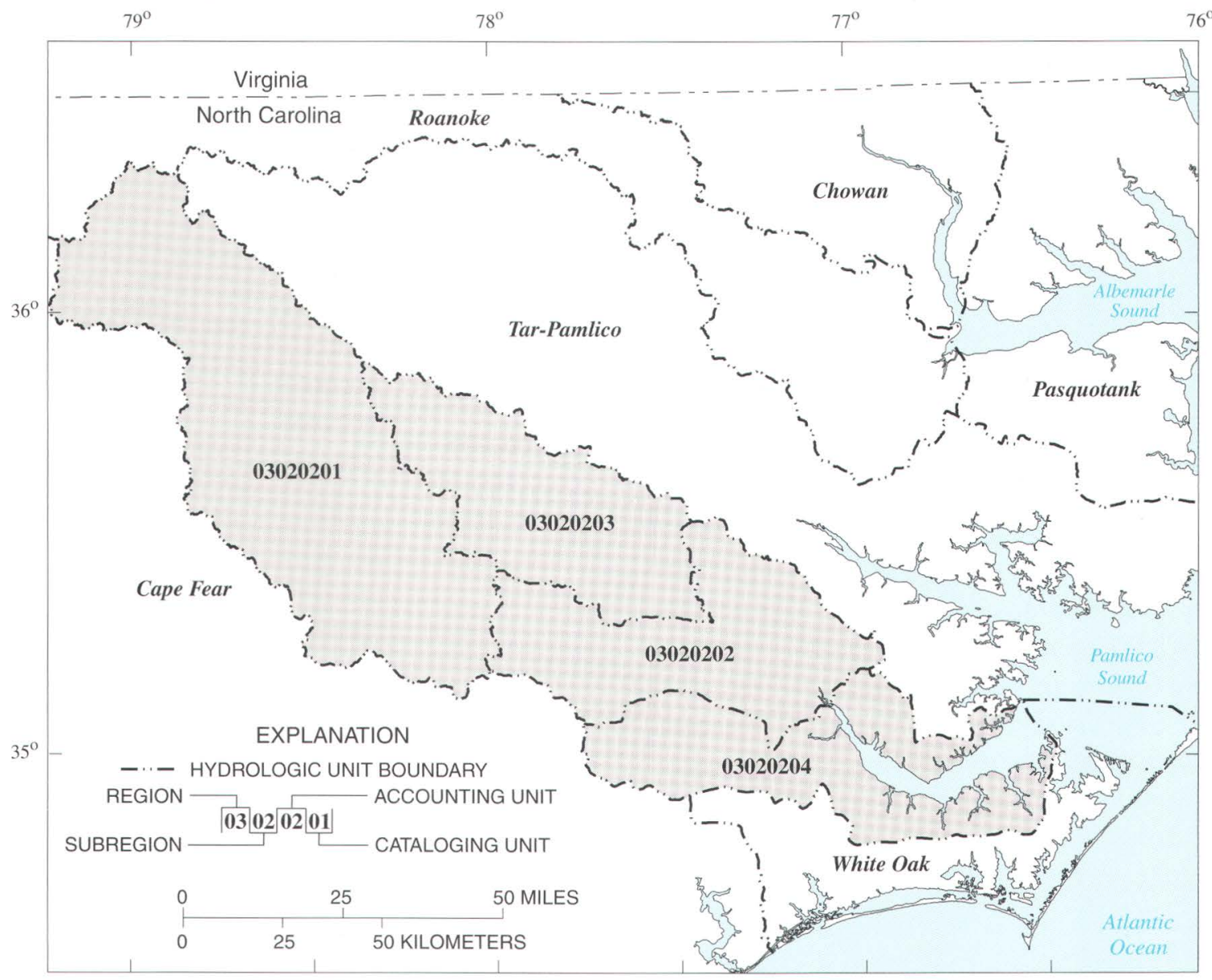

Figure 4. Hydrologic units in the Neuse River Basin, North Carolina.

Table 1. Code, name, and drainage area of USGS hydrologic units in the Neuse River Basin, North Carolina (from Seaber and others, 1987)

[USGS, U.S. Geological Survey; $\mathrm{mi}^{2}$, square mile]

\begin{tabular}{ccc}
\hline $\begin{array}{c}\text { USGS } \\
\text { hydrologic } \\
\text { unit code } \\
\text { (fig. 4) }\end{array}$ & Name & $\begin{array}{c}\text { Drainage } \\
\text { area } \\
\left(\mathbf{m i}^{\mathbf{2}} \mathbf{)}\right.\end{array}$ \\
\hline 03020201 & Upper Neuse [River] & 2,380 \\
03020202 & Middle Neuse [River] & 1,080 \\
03020203 & Contentnea [Creek] & 1,010 \\
03020204 & Lower Neuse [River] & 1,120 \\
\hline & Total & 5,590 \\
\hline
\end{tabular}

Department of Environment, Health, and Natural Resources, 1993). The difference reflects boundary delineations used by the USGS and DWQ in the lower end of the basin. The study area for the Neuse River
Basin is defined in this report by the four USGS hydrologic units (fig. 4). Records of streamflow in these areas are used to determine the low-flow characteristics presented in this report.

\section{Major Rivers and Tributaries}

The Neuse River, the mainstem in the Neuse River Basin, begins as the West Fork Eno River in northern Orange County in the Piedmont of North Carolina. The river becomes the Neuse at the confluence of the Eno and Flat Rivers in Durham County and flows in a general southeasterly direction through the Coastal Plain toward New Bern, in Craven County, and drains into the Pamlico Sound near Maw Point (pl. 1). In 1983, the confluence of the Eno and Flat Rivers was submerged in Falls Lake, and the Neuse River has since been commonly regarded as starting in Wake County at Falls Lake dam. Much of the Neuse River Basin is characterized by the rolling and 
hilly topography of the headwaters, which gradually changes to gentle, rolling terrain with little relief, then to nearly level land surfaces in the Coastal Plain.

The length of the Neuse River is nearly 270 miles (mi) from New Bern to the headwaters of the West Fork Eno River; the length of the river from New Bern to Falls Lake dam is approximately $190 \mathrm{mi}$ (pl. 1). The drainage area of the Neuse River Basin is about 5,600 $\mathrm{mi}^{2}$ and includes the Neuse River estuary (Seaber and others, 1987; table 1). At New Bern, where the Neuse River changes from riverine to estuarine, the drainage area of the river is nearly $4,500 \mathrm{mi}^{2}$. Major tributaries to the Neuse River include the Flat River $\left(175 \mathrm{mi}^{2}\right)$ in Person and Durham Counties; Crabtree Creek $\left(146 \mathrm{mi}^{2}\right)$ and Walnut Creek $\left(46 \mathrm{mi}^{2}\right)$ in Wake County; Swift Creek (289 $\left.\mathrm{mi}^{2}\right)$ in Wake and Johnston Counties; Little River $\left(317 \mathrm{mi}^{2}\right)$ in Wake, Johnston, and Wayne Counties; Contentnea Creek $\left(1,010 \mathrm{mi}^{2}\right)$ in Wilson and Greene Counties, Swift Creek $\left(330 \mathrm{mi}^{2}\right)$ in Pitt and Craven Counties; and the Trent River $\left(519 \mathrm{mi}^{2}\right)$ in Lenoir and Jones Counties.

Tides from the Pamlico Sound affect flows in the lower reaches of the Neuse River and in other streams in the lower part of the basin. The actual extent of tidal effects in streams has not been identified (Giese and others, 1985). However, gage height and streamflow records from recently installed gaging stations on the Neuse River, Swift Creek in Pitt and Craven Counties, and the Trent River are beginning to give a better understanding of the flow dynamics in the lower reaches. At the partial-record measuring site on the Neuse River near Fort Barnwell (site 460, pl. 1; operated as a continuous-record gaging station since October 1996), streamflow records show no evidence of "negative" or reverse flow. However, continual shifts in the stage-discharge rating suggest the probability of backwater effects from tides; that is, streamflow decreases in response to incoming tides. At the gaging stations on Swift Creek at NC 43 near Streets Ferry (site 477, pl. 1) and on the Trent River at Pollocksville (site 500, pl. 1), flows in both upstream and downstream directions have been observed, indicating the presence of tidal flows at these locations. At the long-term gaging stations on the Neuse River at Kinston (site 361, pl. 1) and on the Trent River near Trenton (site 494, pl. 1), streamflow records do not show any effects from tides.

\section{Major Flow Modifications}

Previous discussions have alluded to the complex nature of low-flow hydrology due to geologic, topographic, and climatic factors. An additional complexity in the determination of low-flow characteristics results from the existence of major flow modifications. These modifications can be classified in two general categories-impoundments and diversions of flow. The ongoing addition and, in some instances, removal of these modifications result in continual changes to the low-flow characteristics.

\section{Impoundments}

Impoundments result from the construction of dams on streams and are used to store water for a variety of purposes, including supply, recreation, irrigation, and cooling water. The effects of impoundments on downstream low-flow characteristics vary because of changes in streamflow patterns that result from storage, diversions of water (for supply purposes) that commonly occur within the impoundments, and to a smaller extent, evaporation from the impoundments. Post-impoundment flow durations for downstream flows, particularly below major impoundments, are generally different from pre-impoundment conditions. The most common, and usually most obvious, change in flow durations for streams downstream from impoundments is the reduction in peak flood discharges observed in post-impoundment flows. In a similar manner, some impoundments-particularly those operating under minimum flow releases-serve to augment downstream flows during droughts and thus increase low flows observed below the dam relative to pre-impoundment conditions.

Approximately 550 impoundments with dams having structural heights exceeding $15 \mathrm{ft}$ were identified in the study area (North Carolina Department of Environment, Health, and Natural Resources, unpub. data, 1993). A map showing the dams' locations, generated by using a geographic information system (GIS) coverage of the State's inventory of dams, indicates that the vast majority of dams are in the Upper Neuse River Basin (hydrologic unit 03020201). The topography of stream channels and adjacent floodplains in this hydrologic unit provide more suitable locations for building dams. Many are privately owned impoundments having relatively small surface areas at the spillway level. These impoundments primarily are used as (1) farm ponds, which provide water for irrigation and help reduce 
sediment discharges to streams; (2) recreational lakes at campgrounds and park facilities; or (3) landscape features (ponds) in developed areas.

A number of impoundments in the Neuse River Basin cause widespread inundation of the river valley immediately upstream from the dam. The impoundment having the largest surface area is Falls Lake (12,490 acres) in Wake, Durham, and Granville Counties (pl. 1); the length of the lake at normal pool is nearly $22 \mathrm{mi}$ (North Carolina Department of Environment, Health, and Natural Resources, 1992). Other major impoundments in the study area having surface areas exceeding 200 acres are Little River Reservoir (530 acres) and Lake Michie (508 acres) in Durham County; Lake Butner (374 acres) in Granville County; Lake Crabtree (520 acres), Lake Wheeler (550 acres), and Lake Benson (440 acres) in Wake County; and Buckhorn Reservoir (750 acres) and Wiggins Mill Reservoir (200 acres) in Wilson County. These lakes, owned and operated by nearby municipalities, are primarily used for water supply, flood control, and recreation.

The effect of impoundments on downstream flows is usually determined by minimum flow releases assigned to the dam. Minimum flow releases can occur in one of two forms: (1) a release based on operations that involve the opening and closing of gates at the dam to adjust the amount of discharge, or (2) a release based on the structural characteristics of the dam's flowrelease system, such as a riser-barrel orifice commonly found in smaller impoundments. Not all impoundments in the Neuse River Basin have been assigned minimum flow releases. At Falls Lake, the minimum flow release varies by season from $65 \mathrm{ft}^{3} / \mathrm{s}$ during the winter months to $100 \mathrm{ft}^{3} / \mathrm{s}$ during the summer months. In addition to minimum releases at the dam, flow releases also are adjusted in order to meet target discharges at the longterm gaging station on the Neuse River near Clayton (site 248, pl. 1). These target flows are $184 \mathrm{ft}^{3} / \mathrm{s}$ and $254 \mathrm{ft}^{3} / \mathrm{s}$ during the winter and summer months, respectively.

The presence of minimum flow releases at other smaller impoundments varies across the Neuse River Basin. Variations in the presence of minimum flow releases at smaller impoundments within the basin apparently reflect the age of the dam more than any other factor (James Mead, Division of Water Resources, oral commun., 1997). Increased awareness of environmental concerns during the past few decades has resulted in revised procedures for assessing the effects of dams on downstream flows. The impoundments at Little River Reservoir and Lake Crabtree are two such examples; both dams were constructed in the mid-1980's.

At Little River Reservoir in Durham County, minimum flow releases currently are set at $6 \mathrm{ft}^{3} / \mathrm{s}$ and $2 \mathrm{ft}^{3} / \mathrm{s}$ during the periods December 1 to May 31 and June 1 to November 31, respectively (George Carter, City of Durham, oral commun., 1997). However, no minimum release is specified for nearby Lake Michie, built in the mid-1920's and similar in size to Little River Reservoir. At Lake Crabtree in Wake County, a flow-release mechanism in the dam currently results in a minimum release of approximately $2.6 \mathrm{ft}^{3} / \mathrm{s}$ (Robert Williams, Natural Resources Conservation Service, oral commun., 1997). However, no minimum releases have been assigned to nearby Lake Wheeler or Lake Benson, two small impoundments built in Wake County in 1957 and 1925, respectively, and similar in size to Lake Crabtree.

Other impoundments also operate under varying minimum-release requirements. At Buckhorn Reservoir in Wilson County on Contentnea Creek, the minimum release is $1.3 \mathrm{ft}^{3} / \mathrm{s}$ (James Mead, Division of Water Resources, written commun., 1998).

Downstream on Contentnea Creek at Wiggins Mill Reservoir in Wilson County, no minimum flow releases are required; however, the City of Wilson maintains a minimum flow release of about $1.0 \mathrm{ft}^{3} / \mathrm{s}$ below Wiggins Mill Reservoir.

Milburnie Dam on the Neuse River near Raleigh is the only dam in the Neuse River Basin operated for hydroelectric-power production. No minimum flow release has been assigned at Milburnie Dam (James Mead, Division of Water Resources, written commun., 1998). However, the dam is required to operate in a "run-of-river" mode; that is, flows upstream and downstream from the structure must be approximately equal.

Attempts to understand changes in flow patterns brought about as a result of impoundments often focus on changes that occur after a dam has been constructed because once constructed, most dams become permanent fixtures. In the Neuse River, however, removal of the Quaker Neck Dam (pl. 1) in Wayne County began in December 1997 for the purposes of opening upstream reaches of the Neuse River and its tributaries to fish migration and spawning (The News and Observer, Raleigh, N.C., December 18, 1997). The changes, if any, in low-flow characteristics of the Neuse 
River currently are unknown and are likely better understood pending continued data collection at longterm downstream gaging stations (sites 344,$361 ;$ pl. 1 ). Similarly, a dam located on the Little River at a stateowned hospital facility near Goldsboro was removed in Spring 1998 to improve fish migration and spawning in upstream reaches (W.L. Yonts, Division of Water Resources, written commun., 1998).

\section{Diversions}

Diversions that occur as withdrawals or pointsource discharges have the effect of immediately altering downstream low flows by an amount equal to the diversion rate. Withdrawals are commonly made by municipalities and by some major industries.

Additionally, some withdrawals are made by farms for agricultural and livestock operations. The State of North Carolina currently requires registration of withdrawals that equal or exceed 1 million gallons per day (Mgal/d) (approximately $1.5 \mathrm{ft}^{3} / \mathrm{s}$ ). A total of 65 registered withdrawals were identified within the Neuse River Basin (Thomas Irving, Division of Water Resources, written commun., 1997). Knowledge of low-flow characteristics is important when withdrawals are being made because the State requires that decreased flows downstream from the withdrawals must be sufficient to sustain downstream uses during drought conditions, including the assimilation of treated effluent.

Point-source discharges into streams are permitted through the issuance of National Pollution Discharge Elimination System (NPDES) permits. In North Carolina as well as in other States, permits that set limits for discharges of treated effluent are based, in part, on the 7Q10 discharge. Similar to withdrawals, flows upstream from the discharge point must be sufficient to assimilate the treated effluent while maintaining other uses of the stream. As of 1998, DWQ has issued 185 NPDES permits for point-source discharges within the Neuse River Basin (Charles Weaver, Division of Water Quality, oral commun., 1998). The number of NPDES permits continuously evolves as a result of the addition and rescission of permitted discharges in the basin. Within the Neuse River Basin, 28 permit holders (21 municipal, 7 industrial) are designated by the DWQ as major dischargers. Major dischargers generally are defined as facilities discharging more than $1 \mathrm{Mgal} / \mathrm{d}$ or facilities having discharges that include high levels of toxicants or metals.
Data describing major withdrawals and pointsource discharges in the study area were obtained from the different State agencies that monitor flow diversions. For selected facilities, average surfacewater withdrawals and point-source discharges reported for calendar year 1996 were compiled into a summary that lists the magnitudes of streamflow changes in the affected streams (table 2). In most instances, point-source discharges were paired with a corresponding surface-water withdrawal on the same stream, often a short distance upstream from the discharge point. The NPDES permit number and permitted flow rate assigned to the permit also are listed for each facility.

Some of the facilities that discharge into streams do not obtain water through surface-water withdrawals. Rather, withdrawals are made from ground-water wells (primarily in the Coastal Plain) or are transferred from other facilities. An additional form of withdrawal listed with the State agencies is that made by large mining operations, which remove ground water from mining pits as part of the quarry operation. In the study area, withdrawals by numerous quarry operations in Durham, Wake, Johnston, and Wilson Counties were registered with the State. However, these are not listed in table 2 because withdrawal and point-source discharge rates are not documented. Also not listed in table 2 are withdrawals and point-source discharges for a number of farming or agricultural-research operations that withdraw water primarily for irrigation purposes. Most of these withdrawals are from groundwater wells or small ponds located on property owned by the operations.

In the Neuse River Basin, the largest withdrawal and, correspondingly, the largest point-source discharge are made by the City of Raleigh for municipal supply purposes. In 1996, the city withdrew an average of $43.0 \mathrm{Mgal} / \mathrm{d}$ from the Neuse River via Falls Lake and discharged an average $33.9 \mathrm{Mgal} / \mathrm{d}$ into the Neuse River just upstream from the Johnston County line. Other significant withdrawals are made by the Cities of Durham and Goldsboro. The 1996 average withdrawal for Durham represents the sum of the withdrawals made from Lake Michie and Little River Reservoir (table 2). The significant difference between the average withdrawal (27.6 Mgal/d) and point-source discharge (9.4 Mgal/d) by the City of Durham is a result of an interbasin transfer to the Cape Fear River Basin (fig. 1; table 2). The average point-source discharge $(8.7 \mathrm{Mgal} / \mathrm{d})$ by the City of Goldsboro is 
Table 2. Summary of selected flow modifications by surface-water withdrawals and point-source discharges to streams in the Neuse River Basin, 1996

[Mgal/d, million gallons per day ( $1 \mathrm{Mgal} / \mathrm{d}$ is equivalent to approximately 1.5 cubic feet per second); NPDES, National Pollution Discharge Elimination System; N/A, not applicable; UT, unnamed tributary; WWTP, wastewater-treatment plant; N/D, not documented. For streams profiled in this report, river miles to the nearest tenth are listed in parentheses beside stream names]

\begin{tabular}{|c|c|c|c|c|c|c|c|c|}
\hline County & Facility name & Purpose & Source of withdrawal & 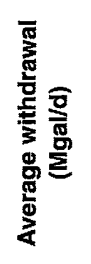 & $\begin{array}{l}\text { Destination of } \\
\text { point-source } \\
\text { discharge }\end{array}$ & 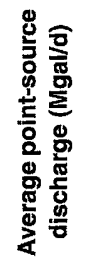 & $\begin{array}{l}\text { NPDES } \\
\text { permit } \\
\text { number }\end{array}$ & 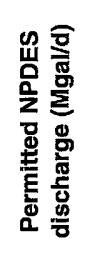 \\
\hline Orange & $\begin{array}{l}\text { Orange-Alamance } \\
\text { Water System }\end{array}$ & Public water supply & $\begin{array}{l}\text { Eno River (via Corpora- } \\
\text { tion Lake, } \\
\text { mile 298.2) }\end{array}$ & 0.84 & $\begin{array}{l}\text { Eno River } \\
\quad \text { (mile 298.1) }\end{array}$ & 0.02 & NC0082759 & 0.05 \\
\hline Orange & Town of Hillsborough & Public water supply & $\begin{array}{c}\text { Eno River (via Lake Ben } \\
\text { Johnson, mile 296.6) }\end{array}$ & 1.6 & $\begin{array}{l}\text { Eno River } \\
\quad \text { (mile 292.9) }\end{array}$ & 1.3 & NC0026433 & 3.0 \\
\hline Granville & $\begin{array}{l}\text { John Umstead } \\
\text { Hospital (Butner) }\end{array}$ & Public water supply & $\begin{array}{l}\text { Knap of Reeds Creek } \\
\text { (via Lake Butner, also } \\
\text { known as Holt } \\
\text { Reservoir) }\end{array}$ & 2.2 & $\begin{array}{c}\text { Knap of Reeds } \\
\text { Creek }^{\mathrm{a}}\end{array}$ & 2.2 & NC0026824 & 3.5 \\
\hline Granville & Town of Creedmoor & Public water supply & $\begin{array}{l}\text { Ledge Creek } \\
\quad \text { (via Lake Rogers) }\end{array}$ & .28 & $\mathrm{~N} / \mathrm{A}^{\mathrm{b}}$ & $\mathrm{N} / \mathrm{A}^{\mathrm{b}}$ & $\mathrm{N} / \mathrm{A}^{\mathrm{b}}$ & $\mathrm{N} / \mathrm{A}^{\mathrm{b}}$ \\
\hline Durham & City of Durham & Public water supply & $\begin{array}{l}\text { Flat River } \\
\text { (8.2 Mgal/d via } \\
\text { Lake MIchie) } \\
\text { Little River } \\
\text { (19.4 Mgal/d via } \\
\text { Little River Reser- } \\
\text { voir) }\end{array}$ & 27.6 & Ellerbee Creek & 9.4 & $\mathrm{NC} 0023841^{\mathrm{c}}$ & 20.0 \\
\hline Wake & $\begin{array}{l}\text { Heater Utilities } \\
\quad \text { (Wildwood Green) }\end{array}$ & Public water supply & Ground-water wells & N/A & $\begin{array}{l}\text { UT Lower } \\
\text { Barton Creek }\end{array}$ & .05 & NC0063614 & .1 \\
\hline Wake & Town of Wake Forest & Public water supply & Smith Creek ${ }^{\mathrm{d}}$ & .56 & $\begin{array}{l}\text { Neuse River } \\
\quad \text { (mile 227.7) }\end{array}$ & .87 & NC0030759 & 6.0 \\
\hline Wake & $\begin{array}{l}\text { Heater Utilities } \\
\text { (Beachwood) }\end{array}$ & Public water supply & $\begin{array}{l}\text { Transfer from City of } \\
\text { Raleigh }\end{array}$ & N/A & $\begin{array}{l}\text { Neuse River } \\
\quad \text { (mile 217.5) }\end{array}$ & .01 & NC0060577 & .1 \\
\hline \multirow[t]{2}{*}{ Wake } & \multirow[t]{2}{*}{ Town of Cary } & \multirow[t]{2}{*}{ Public water supply } & \multirow{2}{*}{$\begin{array}{l}\text { Jordan Lake } \\
\text { (Cape Fear River } \\
\text { Basin) }\end{array}$} & \multirow[t]{2}{*}{$\mathrm{N} / \mathrm{A}^{\mathrm{e}}$} & $\begin{array}{l}\text { Crabtree Creek } \\
\text { (North WWTP) }\end{array}$ & 3.7 & NC0048879 & 4.45 \\
\hline & & & & & $\begin{array}{l}\text { Middle Creek } \\
\quad \text { (South WWTP) }\end{array}$ & 4.2 & NC0065102 & 6.4 \\
\hline Wake & $\begin{array}{l}\text { Carolina Water Service } \\
\text { (Ashley Hill) }\end{array}$ & Public water supply & Ground-water wells & N/A & $\begin{array}{l}\text { Poplar Creek } \\
\text { (mile 2.2) }\end{array}$ & .03 & NC0051322 & .125 \\
\hline Wake & City of Raleigh & Public water supply & $\begin{array}{l}\text { Neuse River (via Falls } \\
\text { Lake, mile 233.0) }\end{array}$ & 43.0 & $\begin{array}{l}\text { Neuse River } \\
\quad \text { (mile 208.8) }\end{array}$ & 33.9 & NC0029033 & 60.0 \\
\hline Johnston & Town of Clayton & Public water supply & $\begin{array}{l}\text { Transfer from Johnston } \\
\text { County }\end{array}$ & $\mathrm{N} / \mathrm{A}$ & Little Creek & .95 & $\mathrm{NC} 0025453$ & 1.5 \\
\hline Wake & Town of Apex & Public water supply & $\begin{array}{l}\text { Jordan Lake } \\
\text { (Cape Fear River } \\
\text { Basin) }\end{array}$ & $\mathrm{N} / \mathrm{A}^{\mathrm{e}}$ & UT Middle Creek & 1.1 & NC0064050 & 1.8 \\
\hline Wake & $\begin{array}{l}\text { Town of Fuquay } \\
\text { Varina } \\
\text { (proposed WWTP) }\end{array}$ & Public water supply & $\begin{array}{l}\text { Transfer from City of } \\
\text { Raleigh and } \\
\text { Harnett County }\end{array}$ & N/A & Terrible Creek & .06 & NC0066516 & 6.0 \\
\hline Johnston & Johnston County & Public water supply & $\begin{array}{l}\text { Neuse River } \\
\quad \text { (mile 190.0) }\end{array}$ & $3.5^{\mathrm{f}}$ & $\begin{array}{l}\text { Neuse River } \\
\quad \text { (mile 183.3) }\end{array}$ & 3.1 & $\mathrm{NC} 0030716$ & 4.5 \\
\hline Johnston & Town of Smithfield & Public water supply & $\begin{array}{l}\text { Neuse River (mile } \\
\text { 185.7) }\end{array}$ & 4.0 & $\mathrm{~N} / \mathrm{A}^{\mathrm{g}}$ & $N / A^{g}$ & $N / A^{g}$ & $\mathrm{~N} / \mathrm{A}^{\mathrm{g}}$ \\
\hline
\end{tabular}


Table 2. Summary of selected flow modifications by surface-water withdrawals and point-source discharges to streams in the Neuse River Basin, 1996-Continued

[Mgal/d, million gallons per day (1 Mgal/d is equivalent to approximately 1.5 cubic feet per second); NPDES, National Pollution Discharge Elimination System; N/A, not applicable; UT, unnamed tributary; WWTP, wastewater-treatment plant; N/D, not documented. For streams profiled in this report, river miles to the nearest tenth are listed in parentheses beside stream names]

\begin{tabular}{|c|c|c|c|c|c|c|c|c|}
\hline County & Facility name & Purpose & Source of withdrawal & 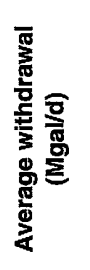 & $\begin{array}{l}\text { Destination of } \\
\text { point-source } \\
\text { discharge }\end{array}$ & 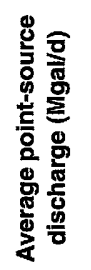 & $\begin{array}{l}\text { NPDES } \\
\text { permit } \\
\text { number }\end{array}$ & 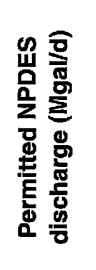 \\
\hline Johnston & Town of Benson & Public water supply & $\begin{array}{l}\text { Transfer from Johnston } \\
\text { County }\end{array}$ & N/A & Hannah Creek & 1.3 & NC0020389 & 1.5 \\
\hline Johnston & Town of Kenly & Public water supply & $\begin{array}{l}\text { Transfer from Johnston } \\
\text { County }\end{array}$ & N/A & $\begin{array}{l}\text { Little River } \\
\quad \text { (mile 35.7) }\end{array}$ & .46 & NC0064891 & .52 \\
\hline Johnston & Town of Princeton & Public water supply & $\begin{array}{l}\text { Transfer from Johnston } \\
\text { County }\end{array}$ & N/A & $\begin{array}{l}\text { Little River } \\
\quad \text { (mile 22.4) }\end{array}$ & .19 & NC0026662 & .275 \\
\hline Wayne & Wayne County & Public water supply & Ground-water wells & N/A & $\begin{array}{l}\text { Neuse River } \\
\text { (Genoa WWTP, } \\
\text { mile 132.8) }\end{array}$ & .11 & NC0030392 & .4 \\
\hline Wayne & $\begin{array}{l}\text { Carolina Power and } \\
\text { Light }\end{array}$ & Cooling water & $\begin{array}{l}\text { Neuse River } \\
\quad \text { (mile 144.8) }\end{array}$ & $\mathrm{N} / \mathrm{D}^{\mathrm{h}}$ & $\begin{array}{l}\text { Neuse River } \\
\text { (mile 144.8) }\end{array}$ & $\mathrm{N} / \mathrm{D}^{\mathrm{h}}$ & NC0003417 & $\mathrm{N} / \mathrm{D}^{\mathrm{h}}$ \\
\hline Wayne & City of Goldsboro & Public water supply & $\begin{array}{l}\text { Neuse Riveri } \\
\quad \text { (mile 136.7) }\end{array}$ & 6.3 & $\begin{array}{l}\text { Neuse River } \\
\text { (mile 131.1) }\end{array}$ & $8.7^{\mathrm{j}}$ & NC0023949 & 10.1 \\
\hline Lenoir & Town of La Grange & Public water supply & Ground-water wells & N/A & Moseley Creek & .56 & NC0021644 & .75 \\
\hline Lenoir & City of Kinston & Public water supply & Ground-water wells & N/A & $\begin{array}{c}\text { Neuse River } \\
\text { (Peachtree } \\
\text { WWTP, } \\
\text { mile 84.4) } \\
\text { (Northside } \\
\text { WWTP, } \\
\text { mile 78.0) }\end{array}$ & $\begin{array}{l}5.1 \\
1.6\end{array}$ & $\begin{array}{l}\text { NC0020541 } \\
\text { NC0024236 }\end{array}$ & $\begin{array}{l}6.75 \\
4.5\end{array}$ \\
\hline Lenoir & DuPont (Kinston) & Manufacturing & Ground-water wells & N/A & $\begin{array}{l}\text { Neuse River } \\
\quad \text { (mile 73.8) }\end{array}$ & 1.4 & NC0003760 & 3.6 \\
\hline Wake & Town of Zebulon & Public water supply & Little River (mile 67.8) & .54 & $\begin{array}{l}\text { UT Moccasin } \\
\text { Creek }\end{array}$ & $.96^{\mathrm{k}}$ & NC0079316 & 1.85 \\
\hline Wilson & City of Wilson & Public water supply & $\begin{array}{l}\text { Contentnea Creek } \\
\text { (5.5 Mgal/d via } \\
\text { Wiggins Mill Reser- } \\
\text { voir, mile } 78.0 \text { ) } \\
\text { Toisnot Swamp } \\
\text { (2.4 Mgal/d via } \\
\text { Toisnot Lake) }\end{array}$ & 7.9 & $\begin{array}{l}\text { Contentnea Creek } \\
\text { (mile 75.0) }\end{array}$ & $10.3^{1}$ & NC0023906 & 12.0 \\
\hline Wilson & Town of Stantonsburg & Public water supply & Ground-water wells & N/A & $\begin{array}{l}\text { Contentnea Creek } \\
\text { (mile 57.0) }\end{array}$ & .30 & NC0057606 & .375 \\
\hline Greene & Town of Snow Hill & Public water supply & Ground-water wells & N/A & $\begin{array}{l}\text { Contentnea Creek } \\
\text { (mile 31.1) }\end{array}$ & .25 & NC0020842 & .25 \\
\hline Greene & $\begin{array}{l}\text { Maury Sanitary Land } \\
\text { District }\end{array}$ & Public water supply & Ground-water wells & N/A & $\begin{array}{l}\text { Contentnea Creek } \\
\text { (mile 21.8) }\end{array}$ & .16 & NC0061492 & .225 \\
\hline Greene & Town of Walstonburg & Public water supply & Ground-water wells & N/A & Thompson Swamp & .06 & NC0020362 & .138 \\
\hline Greene & Town of Farmville & Public water supply & Ground-water wells & N/A & $\begin{array}{l}\text { Little Contentnea } \\
\text { Creek }\end{array}$ & 1.8 & NC0029572 & 3.5 \\
\hline Lenoir & $\begin{array}{l}\text { Contentnea Sewerage } \\
\text { District }\end{array}$ & Public water supply & Ground-water wells & N/A & $\begin{array}{l}\text { Contentnea Creek } \\
\text { (mile 2.1) }\end{array}$ & 1.8 & NC0032077 & 2.85 \\
\hline
\end{tabular}


Table 2. Summary of selected flow modifications by surface-water withdrawals and point-source discharges to streams in the Neuse River Basin, 1996-Continued

[Mgal/d, million gallons per day ( $1 \mathrm{Mgal} / \mathrm{d}$ is equivalent to approximately 1.5 cubic feet per second); NPDES, National Pollution Discharge Elimination System; N/A, not applicable; UT, unnamed tributary; WWTP, wastewater-treatment plant; N/D, not documented. For streams profiled in this report, river miles to the nearest tenth are listed in parentheses beside stream names]

\begin{tabular}{|c|c|c|c|c|c|c|c|c|}
\hline County & Facility name & Purpose & Source of withdrawal & 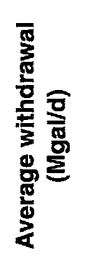 & $\begin{array}{l}\text { Destination of } \\
\text { point-source } \\
\text { discharge }\end{array}$ & 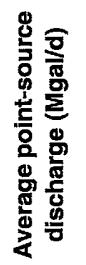 & $\begin{array}{c}\text { NPDES } \\
\text { permit } \\
\text { number }\end{array}$ & 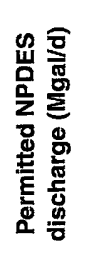 \\
\hline Craven & $\begin{array}{l}\text { Weyerhaeuser } \\
\text { (New Bern) }\end{array}$ & Industrial & Neuse River (mile 51.6) & 20.0 & $\begin{array}{l}\text { Neuse River } \\
\text { (mile 46.3) }\end{array}$ & 19.4 & NC0003191 & 32.0 \\
\hline Craven & $\begin{array}{l}\text { Craven County Wood } \\
\text { Energy }\end{array}$ & Cooling water & Ground-water wells & $\mathrm{N} / \mathrm{A}$ & Bachelor Creek & .22 & NC0075281 & .425 \\
\hline Craven & Town of Vanceboro & Public water supply & Ground-water wells & $\mathrm{N} / \mathrm{A}$ & Mauls Swamp & .14 & NC0031828 & .25 \\
\hline Craven & City of New Bern & Public water supply & Ground-water wells & N/A & $\begin{array}{l}\text { Neuse River } \\
\quad \text { (mile 40.4) }\end{array}$ & 3.2 & NC0025348 & 4.7 \\
\hline Craven & Town of River Bend & Public water supply & Ground-water wells & $\mathrm{N} / \mathrm{A}$ & $\begin{array}{l}\text { Trent River } \\
\quad \text { (mile 7.1) }\end{array}$ & .14 & NC0030406 & .33 \\
\hline Craven & $\begin{array}{l}\text { CWS Systems, Inc. } \\
\text { (NE Craven } \\
\text { Utilities) }\end{array}$ & Public water supply & Ground-water wells & N/A & $\begin{array}{l}\text { Neuse River } \\
\quad \text { (mile 31.0) }\end{array}$ & .24 & NC0033111 & .60 \\
\hline Craven & City of Havelock & Public water supply & Ground-water wells & N/A & $\begin{array}{l}\text { East Prong Slocum } \\
\text { Creek }\end{array}$ & 1.3 & $\mathrm{NC} 0021253$ & 1.5 \\
\hline Craven & $\begin{array}{l}\text { USMC Air Station } \\
\text { (Cherry Point) }\end{array}$ & Public water supply & Ground-water wells & N/A & Slocum Creek & 2.3 & NC0003816 & 3.6 \\
\hline Pamlico & Oriental WWTP & Public water supply & Ground-water wells & $\mathrm{N} / \mathrm{A}$ & Smith Creek & .12 & NC0057011 & .10 \\
\hline
\end{tabular}

${ }^{\text {a }}$ Prior to current NPDES permit, facility discharged to nearby Picture Creek under NPDES permit NC0058416 (permitted flow 0.1 Mgal/d).

${ }^{b}$ Wastewater from Creedmoor treated and released by wastewater-treatment facility operated by John Umstead Hospital (Butner).

${ }^{c}$ City of Durham also has wastewater-treatment plant that discharges to New Hope Creek in Cape Fear River Basin under separate NPDES permit.

${ }^{\mathrm{d}}$ Town of Wake Forest also obtains water via transfer from the City of Raleigh.

${ }^{\mathrm{e}}$ Towns of Cary and Apex jointly operate a water-treatment plant that withdraws water from B. Everett Jordan Lake in the Cape Fear River Basin. Apex receives up to 23 percent of the daily withdrawal; average daily withdrawal from Jordan Lake in 1996 was $10.5 \mathrm{Mgal} / \mathrm{d}$.

${ }^{\mathrm{f}}$ Water-treatment plant opened in September 1996. Maximum treatment capacity is $4.0 \mathrm{Mgal} / \mathrm{d}$; estimated average withdrawal of $3.5 \mathrm{Mgal} / \mathrm{d}$ is based on observations of plant operations since the facility opened (James Davis, Johnston County water-treatment plant, oral commun., 1997). Facility distributes water to nearby small municipalities, which treat their own wastewater.

${ }^{\mathrm{g}}$ Wastewater from Smithfield treated and released by wastewater-treatment facility operated by Johnston County.

${ }^{\mathrm{h}}$ No records are available to determine average flow diversions by Carolina Power and Light at this powerplant in Wayne County. Pumps used for making withdrawals are capable of pulling nearly $32 \mathrm{Mgal} / \mathrm{d}$ when operated full-time in the summer seasons, and average point-source discharge is typically about $3 \mathrm{Mgal} / \mathrm{d}$ (H. Sideras, Carolina Power and Light, oral commun., 1997).

i City of Goldsboro also withdraws from the Little River (mile 4.0) on an emergency basis.

$\mathrm{j}$ While the City of Goldsboro treats some wastewater from some smaller nearby entities, much of the difference between the average withdrawal and point-source discharge is attributed to infiltration of rainfall runoff into the pipe network that drains to the wastewater-treatment plant system.

${ }^{\mathrm{k}}$ Beginning in June 1996, the Town of Zebulon purchased water from the City of Raleigh; the higher value for average point-source discharge reflects the treatment of wastewater withdrawn from the Little River and purchased from Raleigh.

${ }^{1}$ Wastewater from nearby Black Creek and Lucama treated and released by wastewater-treatment facility operated by City of Wilson.

higher than the average withdrawal $(6.3 \mathrm{Mgal} / \mathrm{d})$ reported for 1996 (table 2). While this difference is partly attributed to treatment of waste received from nearby smaller municipalities, part of the difference is attributed to infiltration of rainfall runoff into the pipe network that drains to the treatment facility. The largest nonmunicipal withdrawal occurs in Craven County-an average of $20 \mathrm{Mgal} / \mathrm{d}$ was withdrawn from the Neuse River in 1996 by the Weyerhaeuser Company for industrial use (table 2). 


\section{Climate}

The climate in the Neuse River Basin, as throughout most of North Carolina, consists of long, hot, humid summers and short, mild winters with brief periods of more moderate, milder conditions during the spring and autumn seasons. The average annual temperature (1961-90) in the study area ranges from $58^{\circ} \mathrm{F}$ in the headwaters of the Neuse River Basin to about $62^{\circ} \mathrm{F}$ in the area of the basin near the mouth of the Neuse River near Maw Point (fig. 5A). Records collected by the National Weather Service at selected observation stations in and near the study area indicate that the average temperature ranges from a minimum of about $40^{\circ} \mathrm{F}$ in January to a maximum of about $78^{\circ} \mathrm{F}$ in July (National Oceanic and Atmospheric

Administration, 1996). In all areas of the Neuse River Basin, temperature extremes in the summer reach levels exceeding $90^{\circ} \mathrm{F}$ for long periods of consecutive days.

Average annual precipitation (1961-90) at selected observation stations in and around the study area ranges from nearly 44 in. in the headwaters of the basin to 52 in. near the mouth of the Neuse River near Maw Point (fig. 5B). The higher temperatures and more abundant moisture in the Coastal Plain reflect the moderating effects exerted by the Atlantic Ocean on the climate in that region (Kopec and Clay, 1975). On a monthly basis, the highest amounts of rainfall occur during July and August. Minimum monthly rainfall averages indicate that the lowest amounts of rainfall generally occur during April at the observation stations in the upper half of the Neuse River Basin, and the lowest amounts occur during October and November at stations in the lower half of the basin. Most rainfall occurring during the warmer months comes from isolated, convective-type storms that arise in the late afternoons and evenings as a result of daytime heating. Rainfall occurring during cooler months is from more organized frontal storms that cover broad areas of the region.

Since 1900, there have been seven major droughts in North Carolina (Zembrzuski and others, 1991). The drought of longest duration affecting streams in the Neuse River Basin occurred during 1950-57 when low flows having a recurrence interval between 30 and 90 years were observed across the State. At the USGS gaging station at Flat River at Bahama (site 74, pl. 1) in Durham County, the lowest daily mean discharge $\left(0.27 \mathrm{ft}^{3} / \mathrm{s}\right)$ and instantaneous discharge $\left(0.23 \mathrm{ft}^{3} / \mathrm{s}\right)$ were recorded on September 24 , and 26, 1968, respectively, for the period of record (July 1925 to September 1994) (U.S. Geological Survey, 1961-96, published annually). Other nearrecord low flows occurred at long-term gaging stations on the Eno River (site 20, pl. 1), Middle Creek (site 284, pl. 1), and Contentnea Creek (site 439, pl. 1) in the fall of 1954 during the 1950-57 drought. Notable droughts affecting streams in the study area also occurred during 1966-71 and 1985-88 (Zembrzuski and others, 1991).

\section{Geology and Soils}

Diverse geology and soils in the Neuse River Basin have varying degrees of effects on the potential for sustained base flows. The geology indirectly affects the potential for sustained base flow through the soils, or overburden, into which the underlying rock units are transposed through the processes of physical and chemical weathering. The extent of fractures in underlying rocks also may be an indicator of the potential to sustain base flow. Because the fractures are conduits for water, a rock unit having an abundance of fractures has a higher degree of storage capacity than does a unit having fewer fractures. In a similar manner, soils that exhibit higher degrees of permeability allow for greater movement of water between surficial aquifers and stream channels than do soils with low permeabilities that limit water movement.

Geology in the Neuse River Basin can be divided into two general regions which roughly correspond to the Piedmont and Coastal Plain Provinces. Most of the study area within the Piedmont is underlain by belts of metamorphic and metavolcanic rocks ranging in age from late Proterozoic to early Paleozoic (North Carolina Geological Survey, 1985). These underlying rocks include granite, granitic gneiss, schist, slate, and phyllite (fig. 6A). The noted exception is the Triassic (early Mesozoic) basin across parts of Wake, Durham, and Granville Counties that is underlain by basalt and fine-grained sedimentary rocks, which include sandstone, siltstone, and shale. These rocks have been characterized as having low porosity and permeabilities (Brown, 1988). The lower permeabilities characteristic of soils derived from Triassic basin rocks support a lower potential for sustained base flows compared to those of the older igneous and metamorphic bedrock. As discussed further in later sections of this report, many sites within 

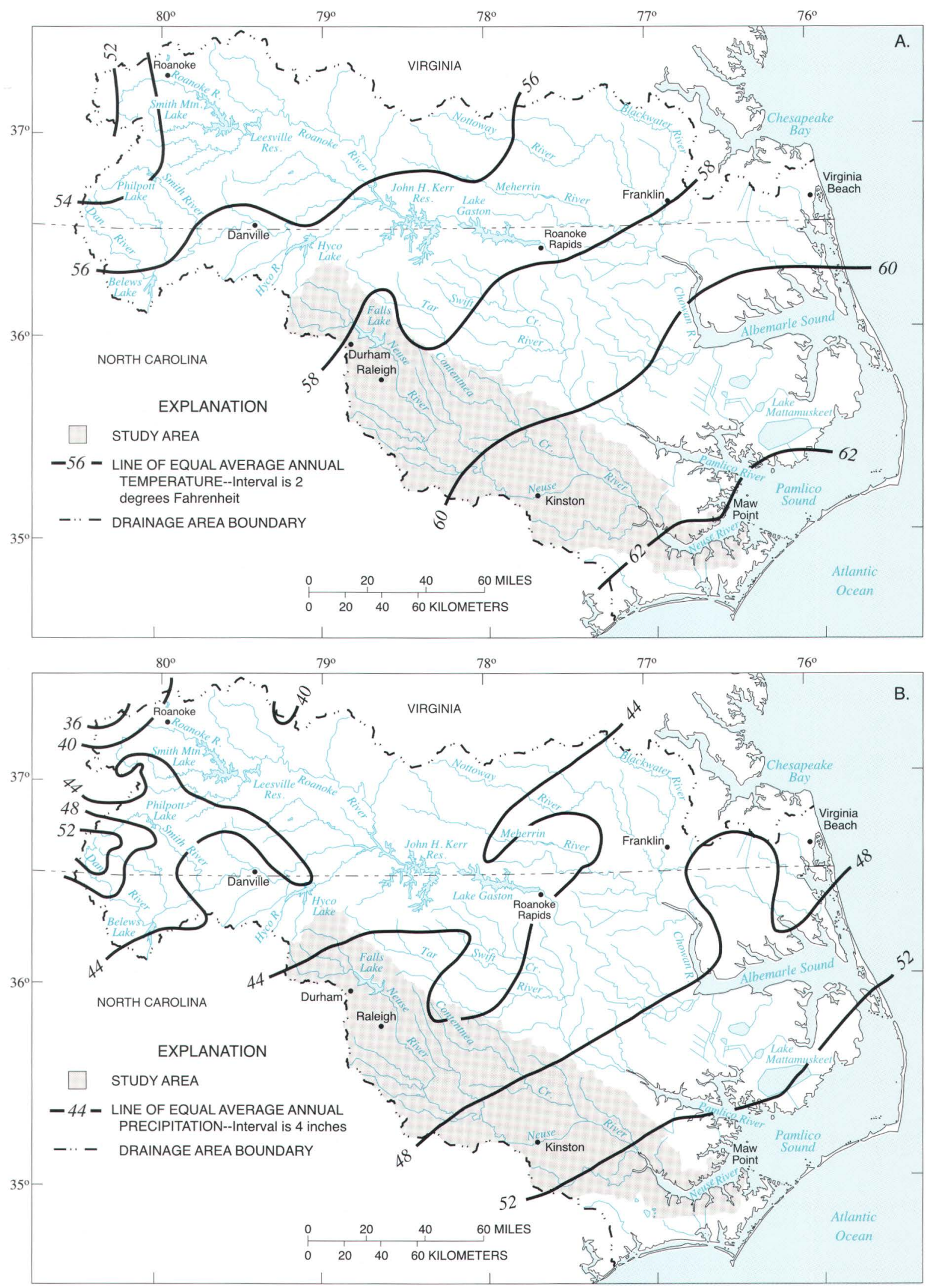

Figure 5. Average annual (A) temperature and (B) precipitation in the Neuse River Basin, 1961-90 (modified from McMahon and Lloyd, 1995). 

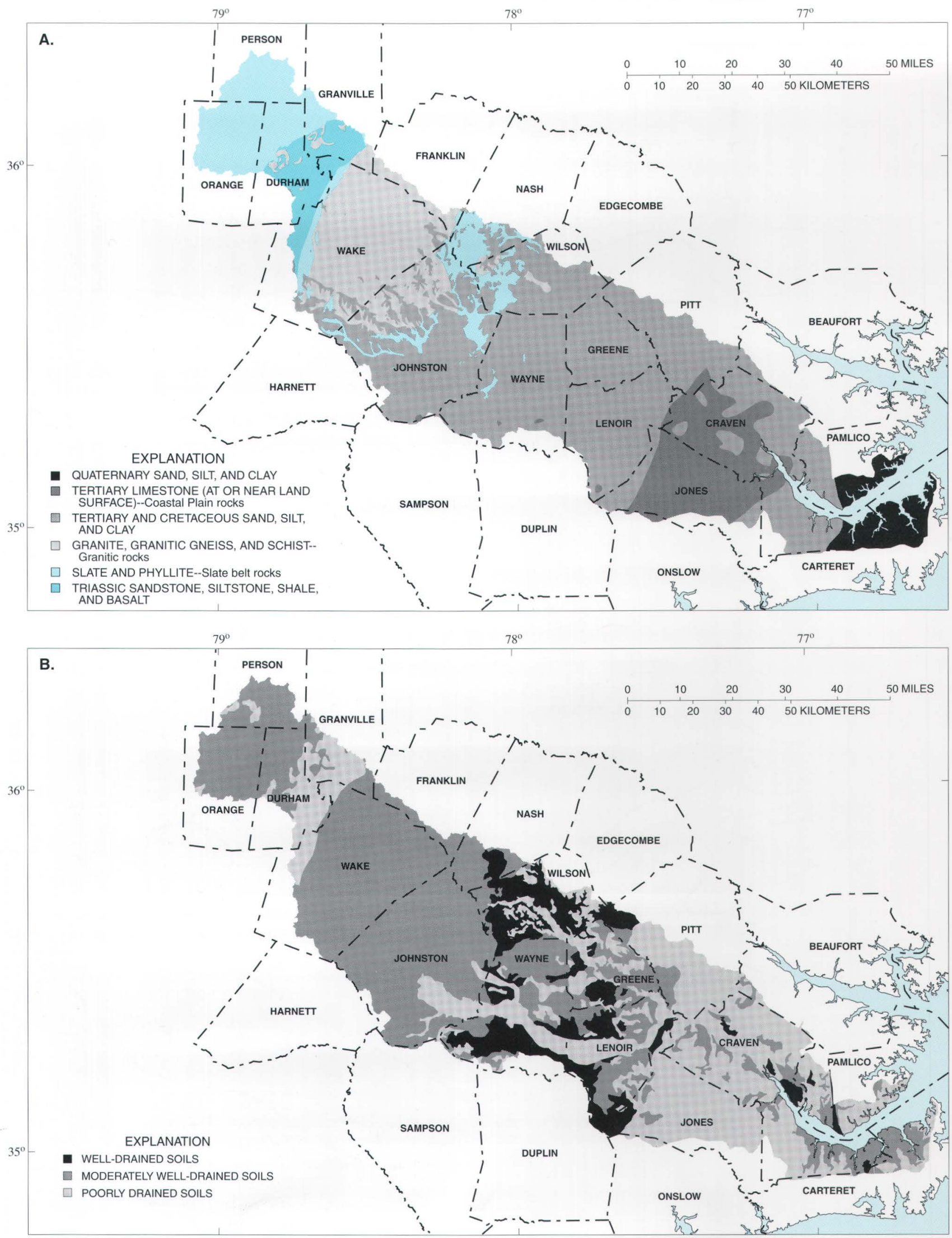

Figure 6. (A) Geology and (B) soil hydrologic groups in the Neuse River Basin, North Carolina (modified from McMahon and Lloyd, 1995). 
the Triassic basin were determined to have 7Q10 discharges equal to zero flow.

The transition from the Piedmont to the Coastal Plain occurs in central Johnston County and western Wilson County, and surface features are initially dissected and rolling with a gradual change from well drained and gently rolling to flat surfaces. In the Coastal Plain, most of the basin is underlain by unconsolidated sediments of Cretaceous to Tertiary age. These sediments are composed of alternating layers of sand, silt, and clay (North Carolina Geological Survey, 1985) (fig. 6A). The Yorktown and Duplin Formations are two dominant geologic units in this area; other units present to a lesser extent include the Peedee, Castle Hayne, and River Bend Formations. A small segment of the basin, lying along the eastern end of the Coastal Plain near the mouth of the Neuse River, is underlain by sediments of Quaternary age, and includes layers of sand, silt, and clay (North Carolina Geological Survey, 1985) (fig. 6A).

Soil surveys conducted by the U.S. Department of Agriculture in the counties within the Neuse River Basin have resulted in the identification of numerous soils associations, or groups of soils having similar characteristics (U.S. Department of Agriculture, various soil surveys, 1912-95). The identification of a predominant soils association throughout the study area is difficult because of the evolving classification methods used in the county soil surveys. However, some soil characteristics that are common among the associations can be recognized, as discussed below.

In the Piedmont, soil associations are moderate to well drained with increasing slopes toward the western edges of the Neuse River Basin. These soils are firm, weathered clay loams derived from igneous and sedimentary bedrock (U.S. Department of Agriculture, various soil surveys, 1912-95). Soils derived from shale and sandstone bedrock of the Triassic basin also occur in this area of the basin. The White StoreCreedmoor association is the predominant soils association from the Triassic basin. The low permeability of the underlying bedrock apparently overrides any drainage characteristic of this soils association and results in a lower potential for sustained base flows relative to the potential in areas occupied by older, weathered clay loams. In the Coastal Plain, the most extensive soils association consists of poorly drained loams, usually along interstream divides having slopes of less than 1 percent (U.S. Department of Agriculture, various soil surveys,
1912-95). In the upper Coastal Plain in Johnston, Wilson, Wayne, and Greene Counties, soils associations contain some moderately drained soils with slightly higher slopes than those in the lower Coastal Plain (U.S. Department of Agriculture, 1994, 1983, 1974b, and 1980, respectively).

Data compiled from Tant and others (1974) indicate that most of the upper half of the study area is covered by soils that are moderately well drained (table 3; fig. 6B). Exceptions to this include areas of Wake, Durham, and Granville Counties where soils from the Triassic basin are poorly drained. The soil hydrologic groups and associated minimum infiltration rates of soils provide an indicator of the water storage within the overburden (Musgrave and Holtan, 1964). Because base flow is defined as sustained flow from ground water or springs, and has no surface-runoff component, the streams in the study area that are covered by moderately well-drained soils will have a high potential for sustained flow during dry conditions, assuming all other factors are equal. Streams in areas underlain by poorly drained soils would be expected to

Table 3. Soil hydrologic groups in the Neuse River Basin, North Carolina [compiled from Musgrave and Holtan (1964) and Tant and others (1974); adapted from McMahon and Lloyd (1995)]

$\left[\mathrm{mi}^{2}\right.$, square mile. Soil characteristics and minimum infiltration rates for soil hydrologic groups are described in table footnotes. Sections of the study area not included (approx. $150 \mathrm{mi}^{2}$ ) are those covered by some of the water bodies and those with unknown soil hydrologic groups. Differences in total drainage area from those listed in other tables reflect differences in scale of map and accuracy of methods used by source to compute areas]

\begin{tabular}{|c|c|c|c|c|c|}
\hline \multicolumn{2}{|c|}{ Well drained } & \multicolumn{2}{|c|}{$\begin{array}{l}\text { Moderately } \\
\text { well drained }\end{array}$} & \multicolumn{2}{|c|}{ Poorly drained } \\
\hline $\begin{array}{c}\text { Soil } \\
\text { group }\end{array}$ & $\begin{array}{l}\text { Area } \\
\left(\mathrm{mi}^{2}\right)\end{array}$ & $\begin{array}{l}\text { Soil } \\
\text { group }\end{array}$ & $\begin{array}{l}\text { Area } \\
\left(\mathrm{mi}^{2}\right)\end{array}$ & $\begin{array}{l}\text { Soil } \\
\text { group }\end{array}$ & $\begin{array}{l}\text { Area } \\
\left(\mathrm{mi}^{2}\right)\end{array}$ \\
\hline $\mathrm{A}^{\mathrm{a}}$ & 579 & $\mathrm{~A} / \mathrm{C}$ & 235 & $\mathrm{~A} / \mathrm{D}$ & 113 \\
\hline \multirow[t]{4}{*}{$\mathrm{A} / \mathrm{B}$} & 46 & $\mathrm{~B}^{\mathrm{b}}$ & 2,124 & $\mathrm{~B} / \mathrm{D}$ & 1,325 \\
\hline & & $\mathrm{B} / \mathrm{C}$ & 443 & $\mathrm{C}^{\mathrm{c}}$ & 33 \\
\hline & & & & $\mathrm{C} / \mathrm{D}$ & 241 \\
\hline & & & & $\mathrm{D}^{\mathrm{d}}$ & 311 \\
\hline
\end{tabular}

${ }^{a}$ Soil Group A—Deep sands, deep loesses, and aggregated soils having minimum infiltration rates of approximately 0.30 to 0.45 inch per hour.

${ }^{\mathrm{b}}$ Soil Group B-Shallow loess and sandy loam soils having minimum infiltration rates of approximately 0.15 to 0.30 inch per hour.

${ }^{\mathrm{c}}$ Soil Group C-Clay loams, shallow sandy loams, soils low in organic matter, and soils high in clay content having minimum infiltration rates of approximately 0.05 to 0.15 inch per hour.

${ }^{\mathrm{d}}$ Soil Group D - Swelling soils, heavy plastic clays, and certain saline soils having minimum infiltration rates of approximately 0 to 0.05 inch per hour. 
have low potential for sustained flows during dry periods. In the lower half of the study area, many of the soils are characterized as poorly drained. Moderately and poorly drained soils occupy nearly 37 and 52 percent, respectively, of the study area. The only occurrences of well-drained soils in the study area (11 percent) are in the central part where these welldrained soils are interspersed with moderately and poorly drained soils (fig. 6B).

\section{Land Use}

Land-use information for the study area was obtained from the U.S. Environmental Protection Agency (USEPA) land-cover information developed from remotely sensed data collected using the Landsat Thematic Mapper (TM) sensor (Vogelmann and others, 1998). The USEPA land-cover information was compiled from aerial photographs taken primarily during the spring seasons of 1991, 1992, and 1993. Information is processed into 15 land-use classes that have been established for eventual development of a consistent and generalized land-cover data base for all of the United States (Vogelmann and others, 1998). In the Neuse River Basin, 6 general categories were identified from the 15 land-use classes in the study area (table 4).

Land use in the Neuse River Basin is mostly rural. Slightly more than 71 percent of the study area is classified as agricultural or forested (table 4). Five percent of the study area is developed land and includes the largest municipalities in the study area-the urban areas of Raleigh in Wake County and Durham in Durham County. Other municipalities within the study area include, from northwest to southeast, Hillsborough in Orange County, Apex and Cary in Wake County, Wilson in Wilson County, Goldsboro in Wayne County, Kinston in Lenoir County, and New Bern in Craven County (pl. 1). Much of the percentage
Table 4. Areas and percentages of land-use categories in the Neuse River Basin, North Carolina

$\left[\mathrm{mi}^{2}\right.$, square mile. Differences in total drainage area from those listed in other tables reflect differences in scale of map and accuracy of methods used by source to compute areas]

\begin{tabular}{|c|c|c|}
\hline \multirow[t]{2}{*}{ Land-use category } & \multicolumn{2}{|c|}{$\begin{array}{l}\text { Extent and percentage o } \\
\text { study area covered by } \\
\text { land-use category a }\end{array}$} \\
\hline & $\left(\mathrm{mi}^{2}\right)$ & (percent) \\
\hline Developed (includes urban areas) & 285 & 5.0 \\
\hline Agricultural & 1,669 & 29.5 \\
\hline Forested & 2,367 & 42.0 \\
\hline Water & 239 & 4.2 \\
\hline Wetlands & 1,030 & 18.2 \\
\hline $\begin{array}{l}\text { Barren (includes quarries, gravel } \\
\text { pits, and transitional areas such as } \\
\text { clear-cut areas) }\end{array}$ & 64 & 1.1 \\
\hline Total & 5,654 & 100.0 \\
\hline
\end{tabular}

${ }^{a}$ From U.S. Environmental Protection Agency land-cover data set (Vogelmann and others, 1998).

shown in table 4 for water ( 4.2 percent) consists of the Neuse River estuary, which begins at New Bern. Other water bodies, such as Little River Reservoir, Lake Michie, Falls Lake, Buckhorn Reservoir, and other smaller impoundments in the Neuse River Basin, account for less than 1 percent of the study area. Wetlands occupy more than 18 percent of the study area and occur primarily in the lower Coastal Plain of the study area.

Land use in much of North Carolina has evolved considerably since the early 1980's. Prior to the Landsat TM data (Vogelmann and others, 1998), the USGS geographic information retrieval and analysis system (GIRAS) was the most recent and comprehensive land-use data available to permit a quantitative assessment of changes in land use within the Neuse River Basin. Information in the GIRAS data base was compiled from aerial photographs taken 
during the late 1970's and mid-1980's (Mitchell and others, 1977). In a similar manner as that completed by McMahon and Lloyd (1995), land-use data in the Neuse River Basin from the GIRAS data base were compared with more recent land-use information from the Landsat TM. However, comparisons between similar categories in the data bases are limited as a result of patterns in percentage changes which conflict with actual observed changes occurring in the Neuse River Basin. For example, comparison of the earlier data base with more recent land-use data indicates a reduction in the percentage of developed land as opposed to observed increases in developed land with the most significant changes occurring in the upper parts of the basin in the Raleigh and Durham municipalities. Population growth in these areas since the mid-1980's has resulted in the widespread conversion of agricultural and forested areas to developed land cover. Also unlikely is the significant percentage increase (from 7 to 18 percent) in wetlands that is suggested by differences in the two data bases. The changes in the percentage of wetlands and other land-use categories likely reflect the methods and resolution of techniques used in compiling the information for each data base.

\section{LOW-FLOW CHARACTERISTICS IN THE NEUSE RIVER BASIN}

Low-flow characteristics were determined for selected gaging stations in the Neuse River Basin. Historical records of gage height and streamflow from 508 sites were compiled (pl. 1); streamflow records were examined (table 5, p. 68-101) for selection of sites where low-flow characteristics could be determined. Records of discharge collected through the 1996 water year were used. Of the 508 sites, 40 were continuous-record gaging stations, 448 were partialrecord measuring sites, and 20 were sites having a combination of continuous- and partial-record discharges. The period of record varies from site to site. The low-flow characteristics for selected sites in the Neuse River Basin are presented in this section.

\section{Continuous-Record Gaging Stations}

Low-flow characteristics based on continuous records of discharge were developed for 50 sites - 35 of the 40 continuous-record gaging stations and 15 of the 20 sites that have both continuous- and partialrecord discharges. Most of these sites were analyzed by using frequency curves (Riggs, 1972); a small number required other graphical correlation techniques, as explained below. The magnitude and frequency of low flows for the continuous-record gaging stations are shown in table 6. Not all sites having continuous records could be used to determine low-flow characteristics. Of the 40 sites having continuousrecord discharges only, low-flow characteristics were not included in table 6 for five sites. Among these five sites, two sites $(55,260)$ are affected by significant regulation upstream from the site, site 477 is significantly affected by tides, site 485 has records of gage height only, and discharge records for site 50 were combined with records at downstream site 51 to develop a long-term set of records for use in determining low-flow characteristics. Of the 20 sites having both continuous- and partial-record discharges, low-flow characteristics likewise were not included in table 6 for five sites. Site 99 is affected by significant diversions upstream from the site, site 210 is located just upstream from another site (212) for which lowflow characteristics were published, site 254 had records of medium- and high-range discharges, site 500 is significantly affected by tides, and low-flow characteristics for site 236 were determined from records of partial-record discharges. 
Table 6. Magnitude and frequency of annual low-flow characteristics at selected continuous-record gaging stations in the Neuse River Basin, North Carolina

$\left[\mathrm{mi}^{2}\right.$, square mile; climatic years, the annual period from April 1 to March 31 and identified by the year in which the period begins; $\left(\mathrm{ft}^{3} / \mathrm{s}\right) / \mathrm{mi}^{2}$, cubic foot per second per square mile; $\mathrm{ft}^{3} / \mathrm{s}$, cubic foot per second; SR, secondary road; PR, gaging station having less than 10 years record of daily mean discharge, treated as a partial-record site where low-flow characteristics were developed by using correlation techniques; $U$, unregulated flow; $C$, estimates based on correlation techniques; <, less than; G, estimates based on best-fit curves developed graphically from the log-Pearson analyses; R, regulated flow; LP, estimates based on log-Pearson frequency distribution; N/A, not available]

\begin{tabular}{|c|c|c|c|c|c|c|c|c|c|c|c|c|c|}
\hline \multirow{2}{*}{ 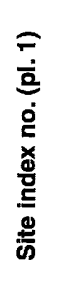 } & \multirow{2}{*}{ 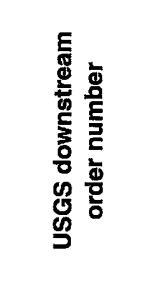 } & \multirow[b]{2}{*}{ Station name } & \multirow{2}{*}{ 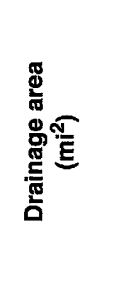 } & \multirow{2}{*}{ 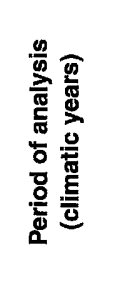 } & \multicolumn{2}{|c|}{$\begin{array}{c}\text { Number of } \\
\text { observed } \\
\text { days of flow }\end{array}$} & \multirow{2}{*}{ 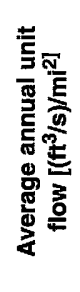 } & \multicolumn{4}{|c|}{$\begin{array}{l}\text { Low-flow characteristics } \\
\qquad\left(\mathrm{ft}^{3} / \mathrm{s}\right)\end{array}$} & \multirow[b]{2}{*}{$\frac{\bar{z}}{\underline{L}}$} & \multirow{2}{*}{ 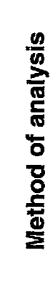 } \\
\hline & & & & & 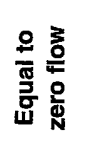 & 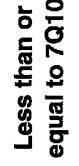 & & 응 & ฮี & $\begin{array}{l}\frac{0}{0} \\
\frac{5}{5}\end{array}$ & ญี & & \\
\hline 9 & 02084903 & $\begin{array}{l}\text { Sevenmile Creek tributary at } \\
\text { SR } 1120 \text { near Buckhorn }\end{array}$ & 1.34 & PR & 9 & 9 & 0.9 & 0 & 0 & 0 & 0 & $\mathrm{U}$ & $\mathrm{C}$ \\
\hline 10 & 02084904 & $\begin{array}{l}\text { Sevenmile Creek tributary at } \\
\text { I-85 near Miles }\end{array}$ & .004 & PR & 336 & 336 & .9 & 0 & 0 & 0 & 0 & $\mathrm{U}$ & $\mathrm{C}$ \\
\hline 11 & 02084905 & $\begin{array}{l}\text { Sevenmile Creek tributary at } \\
\text { SR } 1144 \text { near Miles }\end{array}$ & 1.57 & PR & $0^{\mathrm{a}}$ & 0 & .9 & 0 & $<.05$ & $<.05$ & 0 & $\mathrm{U}$ & $\mathrm{C}$ \\
\hline 13 & 02084908 & $\begin{array}{l}\text { Sevenmile Creek tributary at } \\
\text { I- } 85 \text { near Efland }\end{array}$ & .29 & PR & 140 & 140 & .9 & 0 & 0 & 0 & 0 & $\mathrm{U}$ & $\mathrm{C}$ \\
\hline 14 & 02084909 & Sevenmile Creek near Efland & 14.1 & $1988-95$ & 41 & 41 & 1.0 & 0 & .2 & .3 & .06 & $\mathrm{U}$ & G \\
\hline 20 & 02085000 & Eno River at Hillsborough & 66.0 & $\begin{array}{c}1928-70 \\
1986-95\end{array}$ & 0 & 267 & 1.0 & .5 & 5.3 & 2.2 & 3.2 & $\mathrm{R}^{\mathrm{b}}$ & LP \\
\hline 36 & 02085070 & Eno River near Durham & 141 & $1964-95$ & 0 & 62 & .9 & .7 & 7.2 & 4.3 & 4.1 & $\mathbf{R}^{\mathrm{b}}$ & LP \\
\hline 51 & 02085220 & $\begin{array}{l}\text { Little River near Orange } \\
\text { Factory }^{\mathrm{c}}\end{array}$ & 80.4 & $1962-95^{d}$ & 10 & 351 & .9 & .07 & 4.0 & 1.5 & 2.0 & $\mathrm{U}$ & LP \\
\hline 52 & 0208524090 & $\begin{array}{l}\text { Mountain Creek at SR } 1617 \\
\text { near Bahama }\end{array}$ & 8.0 & PR & 0 & 0 & 1.2 & $<.05$ & .2 & .06 & .1 & $\mathrm{U}$ & $\mathrm{C}$ \\
\hline 74 & 02085500 & Flat River at Bahama ${ }^{c}$ & 149 & $1926-95$ & 0 & 287 & 1.0 & 1.0 & 8.2 & 2.5 & 4.7 & $\mathrm{U}$ & LP \\
\hline 76 & 02086000 & Dial Creek near Bahama $^{c}$ & 4.76 & $\begin{array}{c}1926-70 \\
1990\end{array}$ & 539 & 539 & .9 & 0 & .3 & .1 & .2 & $\mathrm{U}$ & LP \\
\hline 84 & 02086500 & Flat River at dam near Bahama & 168 & $\begin{array}{c}1928-58 \\
1962-65 \\
1983-90\end{array}$ & 32 & 246 & .9 & .05 & 5.0 & .3 & 2.1 & $\mathbf{R}^{\mathrm{e}}$ & LP \\
\hline 85 & 0208650112 & $\begin{array}{l}\text { Flat River tributary near } \\
\text { Willardville }\end{array}$ & 1.14 & PR & 326 & 326 & 1.1 & 0 & $<.05$ & 0 & 0 & $\mathrm{U}$ & $\mathrm{C}$ \\
\hline 89 & 02086624 & $\begin{array}{l}\text { Knap of Reeds Creek near } \\
\text { Butner }\end{array}$ & 43.0 & $1983-94$ & 0 & 14 & 1.0 & 1.4 & 3.2 & 3.1 & 2.4 & $\mathrm{R}^{\mathrm{b}}$ & LP \\
\hline 103 & 02087000 & Neuse River near Northside & 535 & $1928-79$ & 0 & 179 & 1.0 & 10.0 & 44.8 & 18.3 & 29.0 & $R^{f}$ & LP \\
\hline 105 & 0208700780 & $\begin{array}{l}\text { Little Lick Creek above } \\
\text { SR } 1814 \text { near Oak Grove }\end{array}$ & 10.1 & 1983-94 & 0 & 0 & 1.1 & $0^{\mathrm{g}}$ & $\mathrm{N} / \mathrm{A}^{\mathrm{g}}$ & N/A & $\mathrm{N} / \mathrm{A}^{\mathrm{g}}$ & $\mathrm{U}$ & LP \\
\hline 119 & 02087052 & Smith Creek at Grissom & 6.23 & PR & 0 & 0 & 1.0 & .1 & 1.0 & 1.0 & .6 & $\mathrm{U}$ & $\mathrm{C}$ \\
\hline 135 & 02087183 & Neuse River near Falls & 771 & $\begin{array}{l}1971-78 \\
1984-95\end{array}$ & $\begin{array}{l}0 \\
0\end{array}$ & $\begin{array}{r}37 \\
6\end{array}$ & $\begin{array}{r}1.1 \\
.8\end{array}$ & $\begin{array}{l}15.0 \\
57.9\end{array}$ & $\begin{array}{l}48.8 \\
86.3\end{array}$ & $\begin{array}{l}29.8 \\
56.3\end{array}$ & $\begin{array}{l}32.7 \\
82.6\end{array}$ & $\begin{array}{l}\mathrm{R}^{\mathrm{b}} \\
\mathrm{R}^{\mathrm{h}}\end{array}$ & $\begin{array}{l}\text { G } \\
\text { LP }\end{array}$ \\
\hline 144 & 02087190 & $\begin{array}{l}\text { Neuse River at U.S. Hwy } 1 \text { near } \\
\text { Neuse }\end{array}$ & 792 & PR & 0 & 10 & 1.1 & 12.6 & 51.9 & 27.9 & 33.3 & $\mathrm{R}^{\mathrm{b}}$ & $\mathrm{C}$ \\
\hline 153 & 0208721055 & $\begin{array}{l}\text { Perry Creek at SR } 2012 \text { near } \\
\text { Millbrook }\end{array}$ & 2.43 & PR & 1 & 32 & 1.1 & .2 & .6 & .4 & .4 & $\mathrm{U}$ & $\mathrm{C}$ \\
\hline
\end{tabular}


Table 6. Magnitude and frequency of annual low-flow characteristics at selected continuous-record gaging stations in the Neuse River Basin, North Carolina-Continued

$\left[\mathrm{mi}^{2}\right.$, square mile; climatic years, the annual period from April 1 to March 31 and identified by the year in which the period begins; $\left(\mathrm{ft}^{3} / \mathrm{s}\right) / \mathrm{mi}^{2}$, cubic foot per second per square mile; $\mathrm{ft}^{3} / \mathrm{s}$, cubic foot per second; SR, secondary road; PR, gaging station having less than 10 years record of daily mean discharge, treated as a partial-record site where low-flow characteristics were developed by using correlation techniques; $U$, unregulated flow; $\mathrm{C}$, estimates based on correlation techniques; <, less than; G, estimates based on best-fit curves developed graphically from the log-Pearson analyses; R, regulated flow; LP, estimates based on $\log$-Pearson frequency distribution; N/A, not available]

\begin{tabular}{|c|c|c|c|c|c|c|c|c|c|c|c|c|c|}
\hline \multirow{2}{*}{ 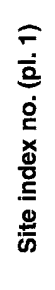 } & \multirow{2}{*}{ 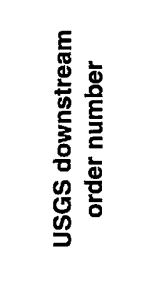 } & \multirow[b]{2}{*}{ Station name } & \multirow{2}{*}{ 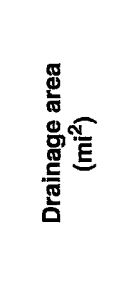 } & \multirow{2}{*}{ 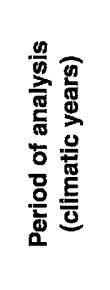 } & \multicolumn{2}{|c|}{$\begin{array}{c}\text { Number of } \\
\text { observed } \\
\text { days of flow }\end{array}$} & \multirow{2}{*}{ 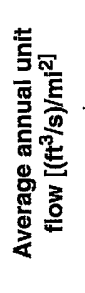 } & \multicolumn{4}{|c|}{$\begin{array}{l}\text { Low-flow characteristics } \\
\qquad\left(\mathrm{ft}^{3} / \mathrm{s}\right)\end{array}$} & \multirow[b]{2}{*}{$\frac{3}{4}$} & \multirow{2}{*}{$\begin{array}{l}\frac{0}{02} \\
\frac{0}{20} \\
\frac{\pi}{\pi} \\
\frac{\pi}{0} \\
\frac{0}{0} \\
\frac{5}{0} \\
\frac{0}{2}\end{array}$} \\
\hline & & & & & 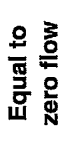 & 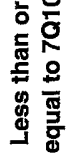 & & 웅 & すूँ & $\frac{0}{0}$ & סี & & \\
\hline 154 & 0208721290 & Perry Creek tributary at Neuse & 1.07 & PR & $0^{\mathrm{a}}$ & 0 & 1.1 & 0 & 0.1 & 0.05 & 0.05 & $\mathrm{U}$ & $\mathrm{C}$ \\
\hline 188 & 0208726005 & $\begin{array}{l}\text { Crabtree Creek at SR } 1649 \text { near } \\
\quad \text { Raleigh }\end{array}$ & 76 & PR & 11 & 13 & .9 & .3 & 3.7 & 1.7 & 1.9 & $R^{i}$ & $\mathrm{C}$ \\
\hline 212 & 02087324 & $\begin{array}{l}\text { Crabtree Creek at U.S. } 1 \text { at } \\
\text { Raleigh }\end{array}$ & 121 & PR & 5 & 12 & 1.2 & 2.0 & 13.0 & 7.8 & 7.9 & $\mathrm{R}^{\mathrm{i}}$ & $\mathrm{C}$ \\
\hline 216 & 0208732810 & $\begin{array}{l}\text { Marsh Creek at SR } 2030 \text { at } \\
\text { Millbrook }\end{array}$ & 1.44 & PR & 0 & 0 & 1.1 & $<.05$ & .3 & .2 & .1 & $\mathrm{U}$ & $\mathrm{C}$ \\
\hline 220 & 0208732885 & Marsh Creek near New Hope & 6.84 & $1986-95$ & 0 & 12 & 1.4 & .3 & 1.5 & .9 & .8 & $\mathrm{U}$ & LP \\
\hline 248 & 02087500 & Neuse River near Clayton & 1,150 & $\begin{array}{l}1928-78 \\
1984-95\end{array}$ & $\begin{array}{l}0 \\
0\end{array}$ & $\begin{array}{r}110 \\
41\end{array}$ & $\begin{array}{r}1.0 \\
.9\end{array}$ & $\begin{array}{l}70.0 \\
148\end{array}$ & $\begin{array}{l}195 \\
249\end{array}$ & $\begin{array}{l}139 \\
170\end{array}$ & $\begin{array}{l}141 \\
215\end{array}$ & $\begin{array}{l}\mathrm{R}^{\mathrm{b}} \\
\mathrm{R}^{\mathrm{h}}\end{array}$ & $\begin{array}{l}\text { LP } \\
\text { LP }\end{array}$ \\
\hline 284 & 02088000 & Middle Creek near Clayton ${ }^{c}$ & 83.5 & $1940-95$ & 19 & 99 & 1.1 & .3 & 9.0 & 4.5 & 4.4 & $\mathrm{U}$ & LP \\
\hline 311 & 02088315 & $\begin{array}{l}\text { Beaverdam Creek near } \\
\text { Grantham }\end{array}$ & 5.01 & PR & 64 & 64 & 1.2 & $<.05$ & .2 & .2 & .1 & $\mathrm{U}$ & $\mathrm{C}$ \\
\hline 330 & 02088470 & Little River near Kenly & 191 & $1965-88$ & 0 & 19 & 1.0 & 1.6 & 13.1 & 12.3 & 8.0 & $\mathbf{R}^{\mathrm{b}}$ & LP \\
\hline 335 & 02088500 & Little River near Princeton & 232 & $1930-95$ & 0 & 151 & 1.1 & 2.5 & 22.7 & 16.6 & 12.8 & $\mathbf{R}^{\mathrm{b}}$ & LP \\
\hline 341 & 02088682 & $\begin{array}{l}\text { Big Ditch at Retha Street at } \\
\text { Goldsboro }\end{array}$ & 2.17 & PR & 16 & 16 & 1.2 & $<.05$ & .3 & .2 & .2 & $\mathrm{U}$ & $\mathrm{C}$ \\
\hline 344 & 02089000 & Neuse River near Goldsboro & 2,399 & $\begin{array}{l}1930-78 \\
1984-95\end{array}$ & $\begin{array}{l}0 \\
0\end{array}$ & $\begin{array}{r}97 \\
671\end{array}$ & $\begin{array}{l}1.1 \\
1.0\end{array}$ & $\begin{array}{l}120 \\
207\end{array}$ & $\begin{array}{l}380 \\
400\end{array}$ & $\begin{array}{l}220 \\
256\end{array}$ & $\begin{array}{l}282 \\
316\end{array}$ & $\begin{array}{l}\mathbf{R}^{b} \\
\mathbf{R}^{h}\end{array}$ & $\begin{array}{l}\text { LP } \\
\text { LP }\end{array}$ \\
\hline 351 & 02089216 & Daileys Creek near Liddell & 3.80 & PR & 0 & 0 & 1.2 & .4 & 1.4 & 1.1 & 1.2 & $\mathrm{U}$ & $\mathrm{C}$ \\
\hline 352 & 02089222 & Bear Creek near Parkstown & 4.27 & PR & 15 & 15 & 1.2 & 0 & .2 & .08 & .09 & $\mathrm{U}$ & $\mathrm{C}$ \\
\hline 355 & 02089252 & Bear Creek at Mays Store & 57.7 & PR & 0 & 0 & 1.1 & 7.9 & 19.0 & 15.0 & 14.3 & $\mathrm{U}$ & $\mathrm{C}$ \\
\hline 361 & 02089500 & Neuse River at Kinston & 2,692 & $\begin{array}{l}1930-78 \\
1984-95\end{array}$ & $\begin{array}{l}0 \\
0\end{array}$ & $\begin{array}{r}123 \\
12\end{array}$ & $\begin{array}{l}1.1 \\
1.0\end{array}$ & $\begin{array}{l}200 \\
250\end{array}$ & $\begin{array}{l}520 \\
550\end{array}$ & $\begin{array}{l}340 \\
360\end{array}$ & $\begin{array}{l}405 \\
430\end{array}$ & $\begin{array}{l}R^{b} \\
R^{h}\end{array}$ & $\begin{array}{l}\text { LP } \\
\text { LP }\end{array}$ \\
\hline 386 & 02090380 & Contentnea Creek near Lucama & 161 & $1965-95$ & 0 & 41 & 1.0 & .3 & 10.6 & 3.8 & 5.0 & $\mathbf{R}^{\mathrm{b}}$ & LP \\
\hline 393 & 02090500 & Contentnea Creek near Wilson & 237 & $1930-53$ & 0 & 79 & 1.0 & .3 & 17.0 & 2.5 & 9.0 & $\mathbf{R}^{\mathrm{j}}$ & LP \\
\hline 397 & 02090512 & $\begin{array}{l}\text { Hominy Swamp at Phillips } \\
\text { Street at Wilson }\end{array}$ & 7.92 & PR & $0^{\mathrm{a}}$ & 0 & 1.1 & 0 & .07 & $<.05$ & $<.05$ & $\mathrm{U}$ & $\mathrm{C}$ \\
\hline 411 & 02090625 & Turner Swamp near Eureka ${ }^{\mathrm{c}}$ & 2.10 & $1969-86$ & 0 & 76 & 1.0 & .3 & .5 & .3 & .4 & $\mathrm{U}$ & LP \\
\hline 430 & 0209096970 & Moccasin Run near Patetown & 1.89 & $1988-95$ & 0 & 33 & 1.5 & .1 & .4 & .4 & .2 & $\mathrm{U}$ & G \\
\hline 432 & 02091000 & Nahunta Swamp near Shine & 80.4 & $1954-95$ & 0 & 131 & 1.0 & 2.6 & 11.7 & 10.0 & 7.7 & $\mathrm{U}$ & LP \\
\hline 439 & 02091500 & Contentnea Creek at Hookerton & 733 & $1929-95$ & 0 & 161 & 1.1 & 30.1 & 94.6 & 57.5 & 67.3 & $\mathrm{R}^{\mathrm{b}}$ & LP \\
\hline 451 & 02091700 & $\begin{array}{l}\text { Little Contentnea Creek near } \\
\text { Farmville }\end{array}$ & 93.3 & $1957-86$ & 0 & 59 & 1.2 & .1 & 4.0 & 1.3 & 1.7 & $\mathrm{U}$ & LP \\
\hline
\end{tabular}


Table 6. Magnitude and frequency of annual low-flow characteristics at selected continuous-record gaging stations in the Neuse River Basin, North Carolina-Continued

$\left[\mathrm{mi}^{2}\right.$, square mile; climatic years, the annual period from April 1 to March 31 and identified by the year in which the period begins; $\left(\mathrm{ft}^{3} / \mathrm{s}\right) / \mathrm{mi}^{2}, \mathrm{cubic}$ foot per second per square mile; $\mathrm{ft}^{3} / \mathrm{s}$, cubic foot per second; SR, secondary road; PR, gaging station having less than 10 years record of daily mean discharge, treated as a partial-record site where low-flow characteristics were developed by using correlation techniques; U, unregulated flow; $\mathrm{C}$, estimates based on correlation techniques; <, less than; G, estimates based on best-fit curves developed graphically from the log-Pearson analyses; R, regulated flow; LP, estimates based on log-Pearson frequency distribution; N/A, not available]

\begin{tabular}{|c|c|c|c|c|c|c|c|c|c|c|c|c|c|}
\hline \multirow{2}{*}{ 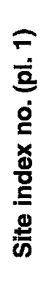 } & \multirow{2}{*}{ 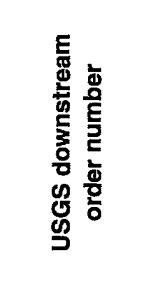 } & \multirow[b]{2}{*}{ Station name } & \multirow{2}{*}{ 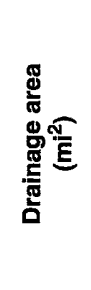 } & \multirow{2}{*}{ 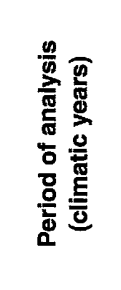 } & \multicolumn{2}{|c|}{$\begin{array}{l}\text { Number of } \\
\text { observed } \\
\text { days of flow }\end{array}$} & \multirow{2}{*}{ 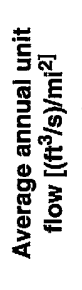 } & \multicolumn{4}{|c|}{$\begin{array}{l}\text { Low-flow characteristics } \\
\qquad\left(\mathrm{ft}^{3} / \mathrm{s}\right)\end{array}$} & \multirow{2}{*}{$\begin{array}{l}\text { 흔 } \\
\frac{1}{4}\end{array}$} & \multirow{2}{*}{ 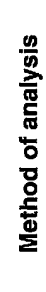 } \\
\hline & & & & & 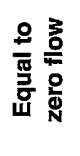 & 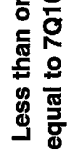 & & $\frac{0}{g}$ & శ్ & $\begin{array}{l}\frac{0}{0} \\
5\end{array}$ & ชี & & \\
\hline 470 & 02091960 & Creeping Swamp near Calico ${ }^{c}$ & 9.8 & PR & 443 & 443 & 1.1 & 0 & 0 & 0 & 0 & $\mathrm{U}$ & $\mathrm{C}$ \\
\hline 471 & 02091970 & $\begin{array}{l}\text { Creeping Swamp near } \\
\text { Vanceboro }^{c}\end{array}$ & 27 & $1971-84$ & 602 & 602 & 1.3 & 0 & 0 & 0 & 0 & $\mathrm{U}$ & LP \\
\hline 472 & 02092000 & Swift Creek near Vanceboro & 182 & $1950-88^{\mathrm{k}}$ & 59 & 199 & 1.1 & 2.1 & 11.2 & 6.2 & 7.5 & $\mathbf{U}$ & LP \\
\hline 475 & 02092020 & $\begin{array}{l}\text { Palmetto Swamp near } \\
\text { Vanceboro }^{c}\end{array}$ & 24.2 & PR & 126 & 126 & 1.1 & 0 & 0 & 0 & 0 & $\mathbf{U}$ & $\mathrm{C}$ \\
\hline 494 & 02092500 & Trent River near Trenton & 168 & $1951-95$ & 0 & 99 & 1.1 & 1.4 & 8.4 & 3.5 & 4.8 & $\mathrm{U}$ & LP \\
\hline 504 & 0209257120 & $\begin{array}{l}\text { W.P. Brice Creek below } \\
\text { SR } 1101 \text { near Riverdale }\end{array}$ & 11.2 & PR & 33 & 89 & 1.2 & .3 & 2.0 & 1.2 & 1.2 & $\mathbf{U}$ & $\mathrm{C}$ \\
\hline
\end{tabular}

${ }^{\text {a }}$ No daily mean discharges equal to zero were observed during the period of record available for low-flow analyses at this site. However, low-flow analyses at this site indicate that the $7 \mathrm{Q} 10$ discharge is zero.

${ }^{b}$ Low-flow characteristics reflect effects of some minor regulation and/or diurnal fluctuation during periods of low flow caused by industries and/or small impoundments upstream from the station. At some sites, low-flow characteristics may reflect the effects of diversions upstream from the station.

${ }^{\mathrm{c}}$ Low-flow characteristics previously published in Giese and Mason (1993). Where different, estimates in this report supersede the previous estimates.

${ }^{\mathrm{d}}$ Period of analysis is based on combined daily mean discharges at continuous-record stations 02085220 (site 51, Sept. 1961-Sept. 1987) and 0208521324 (site 50, Oct. 1987-Sept. 1996).

${ }^{\text {e }}$ Site immediately downstream from dam at Lake Michie; low-flow characteristics reflect flow releases from the dam.

${ }^{f}$ Flows at site during period of record were regulated by Lake Michie and reflective of other flow diversions, including an interbasin transfer to the Cape Fear River Basin.

${ }^{\mathrm{g}}$ Estimates of low-flow characteristics limited to 7Q10 discharge. Prior to November 1994, streamflows affected by NPDES discharge into Little Lick Creek from wastewater-treatment plant upstream from station. The $7 \mathrm{Q} 10$ discharge of zero is estimated on the basis of low-flow characteristics for downstream partial-record site at 02087010 (site 107) having drainage area of $19.4 \mathrm{mi}^{2}$ (see table 7).

${ }^{\mathrm{h}}$ Low-flow characteristics reflect effects of regulation of flows by Falls Lake in Wake County.

${ }^{\mathrm{i}}$ Low-flow characteristics based on streamflow data were adjusted for the effects of an NPDES discharge into Crabtree Creek below the dam at Lake Crabtree and upstream from the station; however, low-flow characteristics reflect effects of regulation by Lake Crabtree.

${ }^{\mathrm{j}}$ Low-flow characteristics reflect effects of regulation by Wiggins Mill Reservoir and withdrawals made by City of Wilson from the reservoir during the period of analysis. Because of increases in average withdrawals, low-flow characteristics likely do not reflect current low-flow characteristics, which cannot be determined. Correspondingly, low-flow characteristics for this site were not used in development of low-flow profiles for Contentnea Creek.

${ }^{\mathrm{k}}$ Channel was canalized in 1954 from a point 12.2 miles upstream to a point 2.5 miles downstream from the gaging station. 
Estimates of low-flow discharges for continuousrecord gaging stations having more than 10 years of record were developed by using frequency curves (Riggs, 1972) (fig. 7). The curves depict the relation between recurrence interval and the lowest average annual discharge for a specified number of days at a gaging station. Frequency curves were developed for annual (climatic year) 7-day and 30-day lowest average discharges as well as for the winter (November through March) 7-day lowest average discharge and then fitted with the log-Pearson Type III frequency distribution. The computed log-Pearson distribution generally corresponds closely to the distribution of annual low flows for sites having long-term periods of record (fig. 7). The method of analysis for these sites is denoted as "LP" in table 6. For sites 14, 135 (records prior to regulation by Falls Lake), and 430, which have short-term records of 8 to 10 years, analyses using the log-Pearson Type III frequency distribution yielded best-fit curves, which were developed graphically from the Weibull plots. The method of analysis for these sites is denoted as " $G$ " in table 6 . The remaining gaging stations having less than 10 years of record, and usually less than 5 years, were treated as partial-record measuring sites using the methods of correlation (described below and denoted as " $\mathrm{C}$ " in table 6).
Seven gaging stations in the study area have records of daily mean discharge on the Neuse River; low-flow characteristics are presented in table 6 for six of the seven stations. The low-flow characteristics at four stations (sites 135, 248, 344, and 361) are presented for pre- and post-regulation flow conditions associated with the presence of Falls Lake, the largest impoundment in the study area. Falls Lake was constructed in the late 1970's and early 1980's. A common base period, the 1984-95 climatic years (April 1, 1984-March 31, 1996), was used to analyze post-regulation discharges at these sites. For analyses of pre-regulation discharges, the available period of record up through the 1978 climatic year (ending March 31, 1979) was used at these same sites and at two additional sites (103 and 144), which were discontinued before the construction of Falls Lake. Low-flow characteristics could not be determined at one station (site 254 at Smithfield) because records of discharge prior to October 1970 are limited to medium and high streamflows. Analyses of the remaining years of streamflow record at site 254 did not produce reliable estimates of low flows for either pre- or postregulation periods.

Where low-flow characteristics at the Neuse River gaging stations are listed in table 6 for pre- and

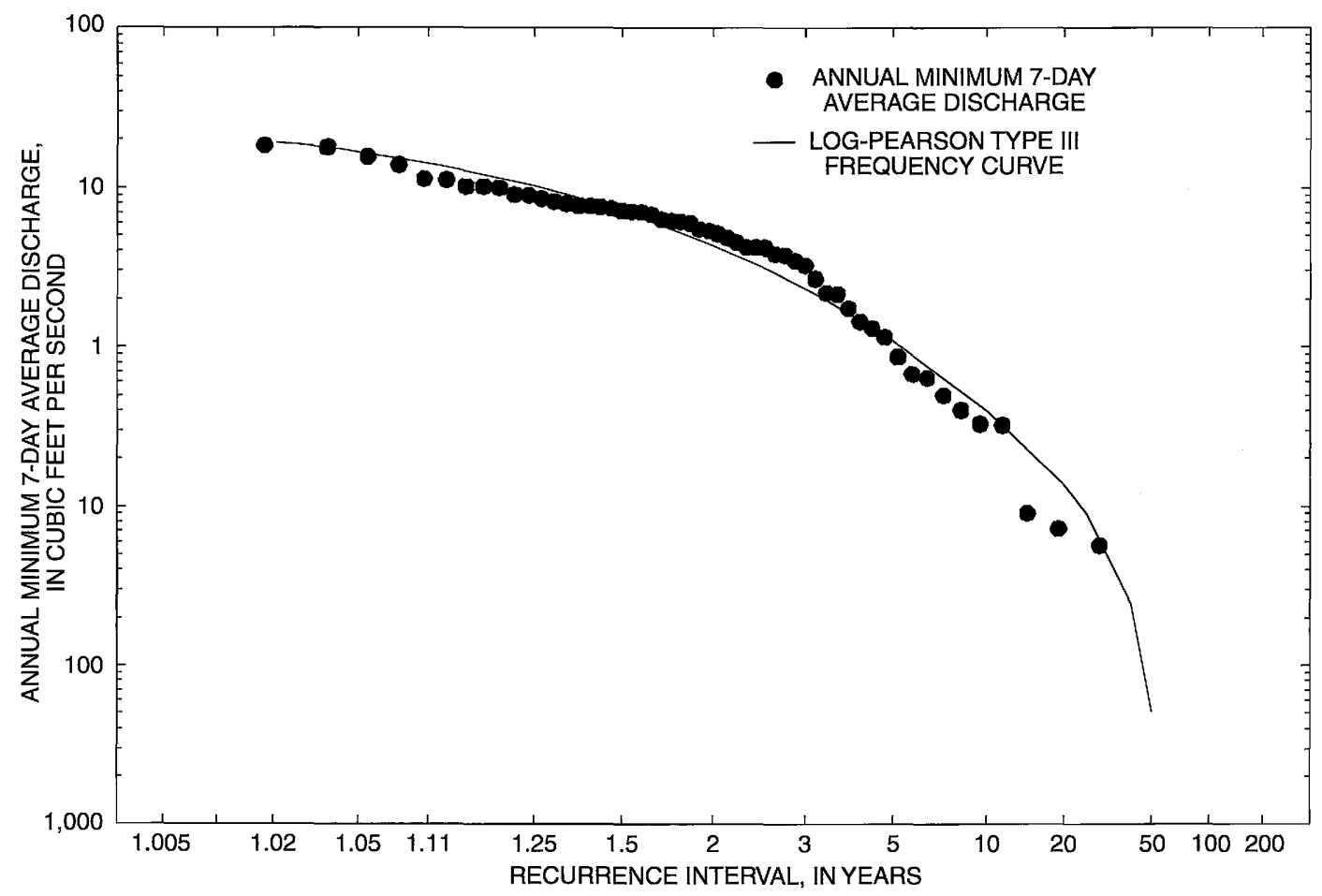

Figure 7. Low-flow frequency curve of annual minimum 7-day discharges using log-Pearson Type III frequency distribution at Middle Creek near Clayton (site 284). 
post-regulation periods (sites $135,248,344$, and 361), only the values for post-regulation flow conditions are used in the discharge profiles presented in this report. Pre-regulation values are listed for comparison purposes only and are intended to provide a means of quantifying the effects of Falls Lake on downstream flows. The effects are most significant at site 135, immediately downstream from the dam, with increases in the low-flow discharges ranging from 80 to nearly 300 percent (table 6). Downstream from the dam, as the ratio of drainage area at a given site to drainage area at the dam increases, the effects of regulation become less significant when compared to pre-regulation conditions. At site 361 at Kinston, where the drainagearea ratio is nearly 3.5 , increases between pre- and post-regulation low flows range from 10 to 30 percent.

The common base period (1984-95) used for a number of sites on the Neuse River downstream from Falls Lake was not applied to the analyses of low flows at other gaging stations. While this period reflects flow conditions in the Neuse River since the construction of Falls Lake, it does not realistically represent a sufficient period of time for use in low-flow analyses at other gaging stations where longer-term records of discharge are available. A number of sites have records of discharge during severe droughts of the 1950's and 1960 's, periods when many record low flows were set. Thus, except for sites where the period of analysis indicated in table 6 is 1984-95 climatic years, low-flow characteristics reflect the available periods of record.

Twenty-two continuous-record gaging stations having less than 10 years of record were treated as partial-record measuring sites for the analysis of lowflow characteristics; the method of analysis is denoted by " $C$ " in table 6 , and the period of analysis is denoted as "PR." Daily mean discharges at these sites were correlated with concurrent flows at nearby long-term continuous-record gaging stations where low-flow characteristics are known. At these sites, available periods of record were used in the correlations.

The presence of upstream regulation and/or diversions in flows is denoted as " $R$ " in table 6; where flows at a gaging station are largely regarded as being unaffected by human-induced flow modifications during the period of record, the flow is denoted as " $U$." By definition, the term "regulation" refers to the artificial manipulation of the flow in a stream (Langbein and Iseri, 1960), an effect only achieved by the presence of a dam having a flow-release system that can be operated to adjust the magnitudes of flow in the stream. In this report, the low-flow characteristics at gaging stations where the flow has been denoted as " $R$ " in table 6 also may reflect the effects of diversions and/or diurnal fluctuations caused by industries and/or small impoundments upstream from the station. Gaging stations denoted as " $R$ " are footnoted to clarify the type of effects on the low-flow characteristics. Lowflow characteristics for the regulated sites can be considered valid as long as these effects of regulation and/or diversions continue to exist.

For sites downstream from flow diversions, no efforts were made to adjust the records of daily mean discharges for changes in flow caused by withdrawals from and point-source discharges to streams. Records of daily flow diversions necessary for making proper adjustments to USGS streamflow records usually are unavailable. In most instances, only annual average flow diversions can be obtained. However, beyond the daily fluctuations in flow diversions, overall average withdrawals and point-source discharges have increased during the past few decades as a result of development and population increases. Thus, efforts to adjust streamflow records at USGS gaging stations on the basis of average flow diversions could result in unreliable estimates of low-flow characteristics. The exception to this occurred at two gaging stations on Crabtree Creek (sites 188 and 212; table 6) in Wake County. Preliminary low-flow analyses at these two sites depicted significant increases in unit low flows between the two locations. With available daily records of point-source discharges from the northern wastewater-treatment facility for the Town of Cary, daily mean discharges at these sites were adjusted to remove the effects of the flow inputs. Discharges from the Town of Cary include flows from an interbasin transfer because Cary's water supply is Jordan Lake in the Cape Fear River Basin (table 2, fig. 1). The lowflow characteristics listed at these two sites reflect the adjusted discharges and, hence, the flow is denoted as " $U$ " in table 6.

\section{Partial-Record Measuring Sites}

Using the techniques discussed by Riggs (1972), low-flow characteristics were determined for 112 of the 448 sites in the Neuse River Basin identified as having partial-record data and for 1 of the 20 combined sites that have both continuous- and partial-record discharges (table 7). Sites having 10 or more discharge measurements were included in the analyses of low- 
Table 7. Magnitude and frequency of annual low-flow characteristics at selected partial-record measuring sites in the Neuse River Basin, North Carolina

$\left[\mathrm{mi}^{2}\right.$, square mile; water years, the annual period from October 1 to September 30 and identified by the year in which the period ends; $\left(\mathrm{ft}^{3} / \mathrm{s}\right) / \mathrm{mi}^{2}$, cubic foot per second per square mile; $\mathrm{ft}^{3} / \mathrm{s}$, cubic foot per second; <, less than; SR, secondary road; N/A, not available]

\begin{tabular}{|c|c|c|c|c|c|c|c|c|c|c|c|}
\hline \multirow{2}{*}{ 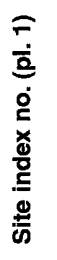 } & \multirow{2}{*}{ 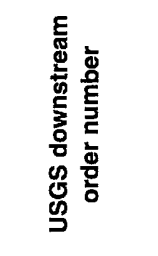 } & \multirow[b]{2}{*}{ Station name } & \multirow{2}{*}{ 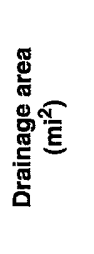 } & \multirow{2}{*}{$\begin{array}{l}\text { Period of } \\
\text { record } \\
\text { (water years) }\end{array}$} & \multicolumn{2}{|c|}{$\begin{array}{l}\text { Number of } \\
\text { measure- } \\
\text { ments }\end{array}$} & \multirow{2}{*}{ 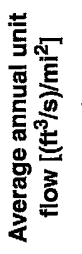 } & \multicolumn{4}{|c|}{$\begin{array}{l}\text { Low-flow characteristics } \\
\qquad\left(\mathrm{ft}^{3} / \mathrm{s}\right)\end{array}$} \\
\hline & & & & & $\frac{3}{0}$ & $\begin{array}{l}\text { 흔 } \\
\frac{0}{\frac{0}{\pi}} \\
\text { N }\end{array}$ & & 号 & ช્๊ & $\frac{0}{0}$ & ฐู \\
\hline 4 & 02084812 & $\begin{array}{l}\text { East Fork Eno River near Cedar } \\
\text { Grove }^{\mathrm{a}}\end{array}$ & 11.46 & $\begin{array}{l}1958,1964,1966, \\
1968\end{array}$ & 4 & 0 & 0.9 & 0.2 & 1.5 & 0.9 & 1.0 \\
\hline 5 & 02084890 & Eno River near Carr ${ }^{\mathrm{a}}$ & 26.7 & $\begin{array}{l}1954-55,1958, \\
1960-64,1966, \\
1968,1970,1986- \\
87\end{array}$ & $21^{b}$ & 0 & .9 & .2 & 3.0 & 2.0 & 1.8 \\
\hline 18 & 02084916 & $\begin{array}{l}\text { Eno River at water-supply intake } \\
\text { near Hillsborough }\end{array}$ & 60.4 & $\begin{array}{l}1954-55,1958 \\
1968,1974-75\end{array}$ & 9 & 0 & .9 & .4 & 4.5 & 1.9 & 2.7 \\
\hline 22 & 02085006 & Cates Creek near Hillsborough ${ }^{\mathrm{a}}$ & 4.18 & $\begin{array}{l}1954-55,1968 \\
1970,1973-74\end{array}$ & 10 & 2 & .9 & $<.05$ & .1 & $<.05$ & .06 \\
\hline 35 & 02085059 & Crooked Creek near Durham & 4.56 & $\begin{array}{l}1958,1964,1966, \\
1968\end{array}$ & 4 & 1 & 1.0 & 0 & 0 & 0 & 0 \\
\hline 39 & 02085114 & Forrest Creek near Cedar Grove & .62 & $\begin{array}{l}1954,1964,1966, \\
1968,1972-73\end{array}$ & 10 & 2 & .9 & 0 & $<.05$ & 0 & 0 \\
\hline 40 & 02085118 & Forrest Creek near Schley & 3.00 & $\begin{array}{l}1954,1968,1972- \\
73\end{array}$ & 10 & 2 & .9 & 0 & $<.05$ & 0 & 0 \\
\hline 42 & 02085130 & $\begin{array}{l}\text { South Fork Little River near Quail } \\
\text { Roost }^{\mathrm{a}}\end{array}$ & 38.2 & $\begin{array}{l}1954,1958,1961- \\
68\end{array}$ & 24 & 0 & 1.0 & .1 & 2.5 & .8 & 1.4 \\
\hline 45 & 02085190 & $\begin{array}{l}\text { North Fork Little River tributary } \\
\text { near Rougemont }\end{array}$ & 1.00 & $1953,1961-76$ & $22^{\mathrm{c}}$ & 4 & .9 & 0 & 0 & 0 & 0 \\
\hline 47 & 02085201 & Buffalo Creek near Rougemont & 5.48 & $\begin{array}{l}1958,1964,1966, \\
1968\end{array}$ & 4 & 3 & .9 & 0 & 0 & 0 & 0 \\
\hline 48 & 02085210 & $\begin{array}{l}\text { North Fork Little River near Orange } \\
\text { Factory }^{\mathrm{a}}\end{array}$ & 29.7 & $1954,1961-68$ & 23 & 1 & 1.0 & $<.05$ & .7 & .2 & .3 \\
\hline 54 & 0208524950 & Little River tributary at Fairntosh & .86 & $1994-96^{\mathrm{d}}$ & 28 & 0 & 1.0 & 0 & 0 & 0 & 0 \\
\hline 56 & 02085262 & Little River near Weaver ${ }^{\mathrm{a}, \mathrm{e}}$ & 104 & $\begin{array}{l}1954,1958,1964, \\
1966,1968,1970\end{array}$ & 6 & 0 & .9 & .2 & 5.8 & 3.7 & 3.4 \\
\hline 58 & 02085302 & South Flat River near Hurdle Mills & 6.22 & $1974-76,1978-84$ & 31 & 1 & 1.0 & 0 & .1 & .08 & .08 \\
\hline 69 & 02085390 & North Flat River at Timberlake ${ }^{a}$ & 33.0 & $\begin{array}{l}1958,1964-68 \\
1970\end{array}$ & 15 & 0 & .9 & .2 & 1.8 & 1.1 & 1.3 \\
\hline 70 & 02085413 & Deep Creek near Surl & 11.6 & $\begin{array}{l}1958,1964,1966, \\
1968\end{array}$ & 4 & 3 & .9 & 0 & 0 & 0 & 0 \\
\hline 72 & 02085430 & Deep Creek near Moriah ${ }^{\mathrm{a}}$ & 32.5 & $\begin{array}{l}1958,1963-68 \\
1970\end{array}$ & 17 & 4 & 1.0 & 0 & .2 & 0 & 0 \\
\hline 75 & 02085810 & Muddy Branch at Bahama & .64 & $\begin{array}{l}1961-66,1968 \\
1970\end{array}$ & 23 & 5 & .9 & 0 & 0 & 0 & 0 \\
\hline 77 & 02086101 & Horner Ford Creek at Bahama & .28 & $\begin{array}{l}1961-64,1968 \\
1970\end{array}$ & 9 & 2 & .9 & 0 & 0 & 0 & 0 \\
\hline 78 & 02086121 & $\begin{array}{l}\text { Horner Ford Creek tributary near } \\
\text { Bahama }\end{array}$ & .28 & $1961-64,1970$ & 8 & 3 & .9 & 0 & 0 & 0 & 0 \\
\hline 79 & 02086275 & Dry Creek near Bahama ${ }^{a}$ & 1.24 & $\begin{array}{l}1961-64,1966 \\
1968,1970\end{array}$ & 10 & 5 & 1.0 & 0 & 0 & 0 & 0 \\
\hline
\end{tabular}


Table 7. Magnitude and frequency of annual low-flow characteristics at selected partial-record measuring sites in the Neuse River Basin, North Carolina-Continued

$\left[\mathrm{mi}^{2}\right.$, square mile; water years, the annual period from October 1 to September 30 and identified by the year in which the period ends; $\left(\mathrm{ft}^{3} / \mathrm{s}\right) / \mathrm{mi}^{2}$, cubic foot per second per square mile; $\mathrm{ft}^{3} / \mathrm{s}$, cubic foot per second; <, less than; SR, secondary road; N/A, not available]

\begin{tabular}{|c|c|c|c|c|c|c|c|c|c|c|c|}
\hline \multirow{2}{*}{ 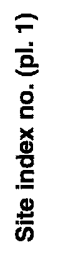 } & \multirow{2}{*}{ 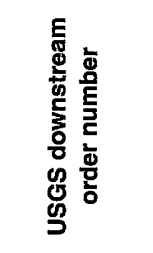 } & \multirow[b]{2}{*}{ Station name } & \multirow{2}{*}{ 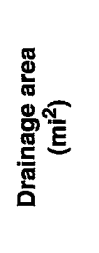 } & \multirow{2}{*}{$\begin{array}{c}\text { Period of } \\
\text { record } \\
\text { (water years) }\end{array}$} & \multicolumn{2}{|c|}{$\begin{array}{l}\text { Number of } \\
\text { measure- } \\
\text { ments }\end{array}$} & \multirow{2}{*}{ 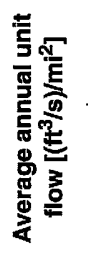 } & \multicolumn{4}{|c|}{$\begin{array}{l}\text { Low-flow characteristics } \\
\qquad\left(\mathrm{ft}^{3} / \mathrm{s}\right)\end{array}$} \\
\hline & & & & & 흔 & $\begin{array}{l}\text { ż } \\
\text { 은 } \\
\frac{9}{9} \\
\text { N }\end{array}$ & & 웅 & ఫ્ల & $\frac{0}{\frac{0}{0}}$ & ฮี \\
\hline 80 & 02086287 & Dry Creek tributary near Bahama & 0.24 & $\begin{array}{l}1961-64,1966 \\
1968,1970\end{array}$ & 10 & 3 & 0.9 & 0 & 0 & 0 & 0 \\
\hline 81 & 02086291 & $\begin{array}{l}\text { Dry Creek tributary no. } 2 \text { near } \\
\text { Bahama }\end{array}$ & 2.08 & $\begin{array}{l}1961-64,1966 \\
1968,1970\end{array}$ & 10 & 6 & .9 & 0 & 0 & 0 & 0 \\
\hline 82 & 02086300 & Rocky Creek near Bahama & 2.30 & $\begin{array}{l}1958,1961-64 \\
1966,1968,1970\end{array}$ & 11 & 1 & .9 & 0 & 0 & 0 & 0 \\
\hline 83 & 02086351 & Rocky Creek tributary near Bahama & .50 & $\begin{array}{l}1961-64,1968 \\
1970\end{array}$ & 9 & 7 & .9 & 0 & 0 & 0 & 0 \\
\hline 86 & 02086570 & Knap of Reeds Creek near Butner & 29.9 & $\begin{array}{l}1954-55,1958 \\
1961-66,1968-69\end{array}$ & 34 & 1 & .9 & .07 & 1.4 & .5 & .7 \\
\hline 107 & 02087010 & Little Lick Creek near Redwood ${ }^{a}$ & 19.4 & $\begin{array}{l}1954,1958,1964- \\
68,1970,1972-73\end{array}$ & 23 & 9 & 1.0 & 0 & .1 & 0 & 0 \\
\hline 112 & 02087024 & $\begin{array}{l}\text { Ledge Creek tributary no. } 2 \text { near } \\
\text { Northside }\end{array}$ & 3.86 & $\begin{array}{l}1958,1961,1964 \\
1968,1970\end{array}$ & 6 & 6 & 1.0 & 0 & 0 & 0 & 0 \\
\hline 118 & 02087046 & $\begin{array}{l}\text { Robertson Creek at NC } 56 \text { near } \\
\text { Creedmoor }\end{array}$ & 9.28 & $\begin{array}{l}1954,1958,1968 \\
1970\end{array}$ & 6 & 5 & 1.0 & 0 & 0 & 0 & 0 \\
\hline 121 & 02087060 & Beaverdam Creek near Creedmoor ${ }^{a}$ & 44.2 & $\begin{array}{l}1954-55,1957-59 \\
1968,1970\end{array}$ & 19 & 7 & 1.1 & 0 & 1.1 & .2 & .5 \\
\hline 124 & 02087080 & New Light Creek near Purnell & 19.2 & $\begin{array}{l}1954-58,1968 \\
1970\end{array}$ & 18 & 0 & 1.0 & 1.6 & 3.8 & 2.4 & 3.1 \\
\hline 125 & 02087120 & Upper Barton Creek near Bayleaf & 12.4 & $\begin{array}{l}1952,1954-58 \\
1968,1970\end{array}$ & 19 & 0 & 1.0 & .5 & 3.1 & 1.7 & 1.9 \\
\hline 127 & 02087160 & Lower Barton Creek near Bayleaf & 13.1 & $\begin{array}{l}1951-54,1958 \\
1968\end{array}$ & 20 & 0 & 1.0 & 1.5 & 3.3 & 2.5 & 2.7 \\
\hline 131 & 02087175 & Horse Creek near Wake Forest & 21.2 & $\begin{array}{l}1949-55,1958-59 \\
1963,1968\end{array}$ & 28 & 0 & 1.0 & 3.6 & 7.9 & 6.0 & 6.4 \\
\hline 136 & 0208718385 & $\begin{array}{l}\text { Hattels Branch at NC } 96 \text { at } \\
\text { Youngsville }\end{array}$ & .1 & $1972-75$ & 9 & 1 & 1.0 & 0 & 0 & 0 & 0 \\
\hline 140 & 02087187 & $\begin{array}{l}\text { Richland Creek at NC } 98 \text { at Wake } \\
\text { Forest }^{\mathrm{a}}\end{array}$ & 7.66 & $1972-74$ & 6 & 0 & 1.1 & .5 & 2.2 & 1.6 & 1.5 \\
\hline 141 & 02087188 & Richland Creek near Forestville & 10.5 & $\begin{array}{l}1954-55,1968 \\
1972-74\end{array}$ & 11 & 0 & 1.1 & .8 & 2.7 & 1.9 & 1.8 \\
\hline 146 & 02087194 & Austin Creek at Wake Forest ${ }^{\mathrm{a}}$ & 3.98 & $1958-59,1968$ & 3 & 0 & 1.1 & .1 & 1.6 & .7 & .8 \\
\hline 159 & 02087220 & $\begin{array}{l}\text { Harris Creek near Wake } \\
\text { Crossroads }^{\mathrm{a}}\end{array}$ & 9.85 & $1954-59,1961-64$ & 22 & 0 & 1.1 & 1.0 & 3.2 & 2.3 & 2.1 \\
\hline 162 & 02087229 & Neuse River near Raleigh & 877 & $\begin{array}{l}1927,1954-55 \\
1974\end{array}$ & 9 & 0 & 1.1 & $39^{f}$ & 130 & 86 & 88 \\
\hline 164 & 0208723280 & $\begin{array}{l}\text { Crabtree Creek at SR } 1615 \text { near } \\
\text { Cary }\end{array}$ & 3.83 & 1973-74 & 6 & 2 & 1.1 & $0^{\mathrm{g}}$ & $\mathrm{N} / \mathrm{A}^{\mathrm{g}}$ & $\mathrm{N} / \mathrm{A}^{\mathrm{g}}$ & $\mathrm{N} / \mathrm{A}^{\mathrm{g}}$ \\
\hline 168 & 02087236 & Crabtree Creek at Morrisville & 14.7 & $\begin{array}{l}1932,1961-62 \\
1968,1972-74\end{array}$ & 10 & 4 & 1.1 & $0^{\mathrm{g}}$ & $N / A^{g}$ & $\mathrm{~N} / \mathrm{A}^{\mathrm{g}}$ & $\mathrm{N} / \mathrm{A}^{\mathrm{g}}$ \\
\hline 169 & 0208723750 & Licks Creek near Morrisville & .3 & $1972-75$ & 8 & 4 & 1.1 & 0 & 0 & 0 & 0 \\
\hline
\end{tabular}


Table 7. Magnitude and frequency of annual low-flow characteristics at selected partial-record measuring sites in the Neuse River Basin, North Carolina-Continued

$\left[\mathrm{mi}^{2}\right.$, square mile; water years, the annual period from October 1 to September 30 and identified by the year in which the period ends; $\left(\mathrm{ft}^{3} / \mathrm{s}\right) / \mathrm{mi}^{2}, \mathrm{cubic}$ foot per second per square mile; $\mathrm{ft}^{3} / \mathrm{s}$, cubic foot per second; <, less than; SR, secondary road; N/A, not available]

\begin{tabular}{|c|c|c|c|c|c|c|c|c|c|c|c|}
\hline \multirow{2}{*}{ 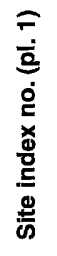 } & \multirow{2}{*}{ 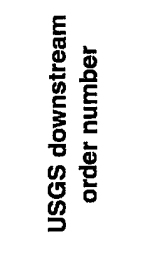 } & \multirow[b]{2}{*}{ Station name } & \multirow{2}{*}{ 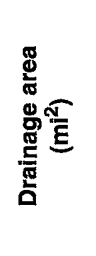 } & \multirow{2}{*}{$\begin{array}{c}\text { Period of } \\
\text { record } \\
\text { (water years) }\end{array}$} & \multicolumn{2}{|c|}{$\begin{array}{c}\text { Number of } \\
\text { measure- } \\
\text { ments }\end{array}$} & \multirow{2}{*}{ 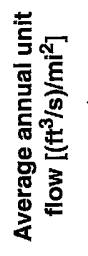 } & \multicolumn{4}{|c|}{$\begin{array}{l}\text { Low-flow characteristics } \\
\qquad\left(\mathrm{ft}^{3} / \mathrm{s}\right)\end{array}$} \\
\hline & & & & & $\frac{3}{\bar{z}}$ & $\begin{array}{l}\frac{3}{0} \\
\frac{0}{2} \\
\text { 윰 } \\
\text { N }\end{array}$ & & $\frac{0}{2}$ & ণั & $\frac{9}{0}$ & वี \\
\hline 171 & 02087238 & Stirrup Iron Creek at Nelson & 7.09 & $\begin{array}{l}1958,1962,1966 \\
1968\end{array}$ & 4 & 4 & 1.1 & 0 & 0 & 0 & 0 \\
\hline 176 & 02087246 & Little Brier Creek near Nelson & 8.58 & $\begin{array}{l}1955,1962,1968 \\
1970\end{array}$ & 6 & 4 & 1.1 & 0 & 0 & 0 & 0 \\
\hline 177 & 02087249 & Stirrup Iron Creek near Morrisville & 25.4 & $\begin{array}{l}1961-62,1968, \\
1972-74\end{array}$ & 10 & 3 & 1.1 & 0 & $<.05$ & 0 & 0 \\
\hline 178 & 02087251 & Crabtree Creek near Cary ${ }^{\mathrm{a}}$ & 52.2 & $\begin{array}{l}1961-62,1968 \\
1982-92,1995-96\end{array}$ & 50 & 0 & 1.1 & .2 & 1.2 & .8 & .8 \\
\hline 195 & 02087270 & Hare Snipe Creek near Millbrook ${ }^{\mathrm{a}}$ & 7.22 & $1961-68,1970$ & 17 & 0 & 1.0 & .2 & 1.2 & .8 & .7 \\
\hline 199 & 02087275 & $\begin{array}{l}\text { Crabtree Creek at U.S. Hwy } 70 \text { at } \\
\text { Raleigh }\end{array}$ & 97.6 & $\begin{array}{l}1932,1942,1947 \\
1949-50,1952-56 \\
1958,1960-63 \\
1968,1973,1978\end{array}$ & 43 & 0 & 1.1 & .4 & 5.0 & 2.4 & 2.6 \\
\hline 200 & 02087290 & Mine Creek near Millbrook $^{\mathrm{a}}$ & 8.87 & $\begin{array}{l}1951-55,1958 \\
1961-62,1968\end{array}$ & 17 & 0 & 1.1 & .8 & 3.2 & 2.4 & 2.4 \\
\hline 209 & 02087320 & Big Branch near Millbrook ${ }^{\mathrm{a}}$ & 3.78 & $\begin{array}{l}1951-55,1958 \\
1961-62,1968\end{array}$ & 17 & 0 & 1.1 & .7 & 1.8 & 1.4 & 1.4 \\
\hline 236 & 02087359 & $\begin{array}{l}\text { Walnut Creek at Sunnybrook Road } \\
\text { at Raleigh }\end{array}$ & 29.4 & $1973-75$ & $12^{\mathrm{h}}$ & 0 & 1.1 & .3 & 7.0 & 4.5 & 4.5 \\
\hline 240 & 02087370 & Big Branch near Garner & 11.8 & $\begin{array}{l}1953-58,1960 \\
1970,1972-73, \\
1976,1979-80\end{array}$ & 30 & 0 & 1.1 & .5 & 2.6 & 1.9 & 1.8 \\
\hline 245 & 02087410 & Poplar Creek near Knightdale ${ }^{\mathrm{a}}$ & 8.83 & $\begin{array}{l}1954-58,1960 \\
1963,1970\end{array}$ & 14 & 0 & 1.1 & .9 & 3.2 & 2.5 & 2.4 \\
\hline 256 & 02087580 & Swift Creek near Apex & 21.0 & $\begin{array}{l}1958,1961-71 \\
1992-95\end{array}$ & 57 & 0 & 1.1 & 0 & .4 & .1 & .1 \\
\hline 258 & 0208758450 & $\begin{array}{l}\text { Dutchmans Branch near McCullers } \\
\text { Crossroads }\end{array}$ & 5.23 & $1987-92$ & 16 & 0 & 1.1 & 0 & .1 & $<.05$ & $<.05$ \\
\hline 262 & 02087610 & Swift Creek near McCullers ${ }^{\mathrm{a}}$ & $55.2^{\mathrm{i}}$ & $1932,1949-53$ & 16 & 0 & 1.1 & .1 & 4.9 & 2.9 & 2.6 \\
\hline 266 & 0208772185 & Swift Creek near Drug Store & 86.6 & $1984-97$ & 40 & 1 & 1.1 & .3 & 7.0 & 3.6 & 3.5 \\
\hline 268 & 02087761 & Little Creek above Clayton & 3.84 & $\begin{array}{l}1954-55,1958 \\
1971,1986\end{array}$ & 9 & 1 & 1.1 & 0 & .3 & .2 & .1 \\
\hline 274 & 02087885 & $\begin{array}{l}\text { Middle Creek at Durham and } \\
\text { Southern Railway near Apex }\end{array}$ & .70 & $1973-76,1979-80$ & 13 & 1 & 1.1 & 0 & 0 & 0 & 0 \\
\hline 283 & 0208796545 & $\begin{array}{l}\text { Terrible Creek at SR } 1404 \text { at Five } \\
\text { Points }\end{array}$ & 4.92 & 1973-75 & 9 & 1 & 1.1 & 0 & .1 & $<.05$ & $<.05$ \\
\hline 285 & 02088030 & Middle Creek near Smithfield & 129.4 & $\begin{array}{l}1949-56,1958 \\
1974,1976,1978 \\
1980-83\end{array}$ & 48 & 0 & 1.1 & .6 & 16.0 & 8.0 & 7.9 \\
\hline 286 & 0208807310 & Black Creek near Willow Springs & 3.87 & $\begin{array}{l}1973-74,1978, \\
1980\end{array}$ & 9 & 2 & 1.1 & 0 & $<.05$ & $<.05$ & 0 \\
\hline 288 & 02088090 & Black Creek near Four Oaks ${ }^{\mathrm{a}}$ & 81.9 & $\begin{array}{l}1949-55,1958-59 \\
1974-75\end{array}$ & 19 & 1 & 1.1 & 0 & 0.3 & $<0.05$ & $<0.05$ \\
\hline
\end{tabular}


Table 7. Magnitude and frequency of annual low-flow characteristics at selected partial-record measuring sites in the Neuse River Basin, North Carolina-Continued

$\left[\mathrm{mi}^{2}\right.$, square mile; water years, the annual period from October 1 to September 30 and identified by the year in which the period ends; $\left(\mathrm{ft}^{3} / \mathrm{s}\right) / \mathrm{mi}^{2}, \mathrm{cubic}$ foot per second per square mile; $\mathrm{ft}^{3} / \mathrm{s}$, cubic foot per second; <, less than; SR, secondary road; N/A, not available]

\begin{tabular}{|c|c|c|c|c|c|c|c|c|c|c|c|}
\hline \multirow{2}{*}{  } & \multirow{2}{*}{ 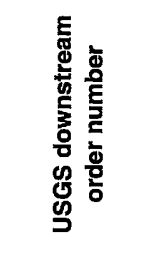 } & \multirow[b]{2}{*}{ Station name } & \multirow{2}{*}{ 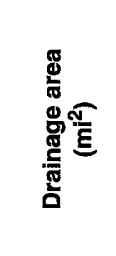 } & \multirow{2}{*}{$\begin{array}{c}\text { Period of } \\
\text { record } \\
\text { (water years) }\end{array}$} & \multicolumn{2}{|c|}{$\begin{array}{l}\text { Number of } \\
\text { measure- } \\
\text { ments }\end{array}$} & \multirow{2}{*}{ 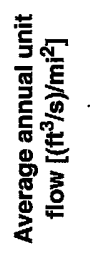 } & \multicolumn{4}{|c|}{$\begin{array}{l}\text { Low-flow characteristics } \\
\qquad\left(\mathrm{ft}^{3} / \mathrm{s}\right)\end{array}$} \\
\hline & & & & & $\frac{\bar{z}}{4}$ & 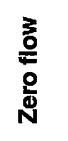 & & 웅 & ชี & $\begin{array}{l}0 \\
\frac{0}{5} \\
5\end{array}$ & ฮี \\
\hline 301 & 02088240 & Hannah Creek near Blackman & 34.7 & $1957-65$ & 14 & 3 & 1.1 & $0^{\mathrm{g}}$ & $\mathrm{N} / \mathrm{A}^{\mathrm{g}}$ & $\mathrm{N} / \mathrm{A}^{\mathrm{g}}$ & $\mathrm{N} / \mathrm{A}^{\mathrm{g}}$ \\
\hline 307 & 02088275 & Mill Creek near Cox Mill ${ }^{\mathrm{a}}$ & 185 & $\begin{array}{l}1954,1958,1965- \\
68,1971,1974 \\
1976,1978-84\end{array}$ & $43^{j}$ & 0 & 1.2 & .7 & 15.7 & 10.7 & 7.0 \\
\hline 310 & 02088310 & Buck Swamp near Dudley ${ }^{\mathrm{a}}$ & 15.5 & $1949-59$ & 22 & 1 & 1.2 & $<.05$ & 1.8 & 1.2 & 6 \\
\hline 315 & 02088332 & Neuse River near Stevens Mill & 2,024 & $\begin{array}{l}1963-64,1974 \\
1976,1978,1980- \\
84\end{array}$ & 40 & 0 & 1.0 & $160^{f}$ & 310 & 200 & 245 \\
\hline 320 & 0208837825 & $\begin{array}{l}\text { Little River at U.S. } 401 \text { near Harris } \\
\text { Crossroads }\end{array}$ & 8.33 & 1974-76, 1979 & 6 & 0 & 1.1 & .1 & .5 & .5 & .4 \\
\hline 321 & 02088380 & Cedar Fork near Rolesville & 4.41 & $\begin{array}{l}1960-64,1966 \\
1968\end{array}$ & 15 & 0 & 1.1 & $<.05$ & .5 & .3 & .2 \\
\hline 324 & 02088415 & $\begin{array}{l}\text { Little River at NC Highway } 42 \text { at } \\
\text { Hares Crossroads }\end{array}$ & 104 & $1969-72$ & 11 & 0 & 1.1 & 1.1 & 8.9 & 8.3 & 5.4 \\
\hline 326 & 02088434 & $\begin{array}{l}\text { Buffalo Creek at Poole Road near } \\
\text { Wendell }^{\mathrm{a}}\end{array}$ & 15.8 & $\begin{array}{l}1955,1958,1972- \\
74\end{array}$ & 9 & 1 & 1.1 & .2 & 1.5 & .9 & .9 \\
\hline 329 & 02088465 & Buffalo Creek near Bagley & 58.5 & $\begin{array}{l}1954,1958,1965- \\
68,1971\end{array}$ & 9 & 1 & 1.1 & .3 & 3.3 & 2.8 & 2.0 \\
\hline 331 & 02088480 & Little Buffalo Creek near Kenly ${ }^{a}$ & 9.34 & $1965-68,1971$ & 7 & 4 & 1.1 & 0 & 0 & 0 & 0 \\
\hline 338 & 0208858110 & Little River at NC 581 near Asylum & 284 & $1974,1976,1978$ & 6 & 0 & 1.1 & 4.6 & 31.7 & 24.1 & 19.2 \\
\hline 345 & 02089020 & Stoney Creek at Goldsboro & 21.6 & $1949-55,1957-58$ & 21 & 0 & 1.2 & .3 & 2.2 & 1.2 & 1.3 \\
\hline 348 & 02089116 & Neuse River near Whitehall & 2,471 & $1972-73$ & 9 & 0 & 1.1 & $175^{\mathrm{f}}$ & 450 & 300 & 363 \\
\hline 349 & 02089120 & Walnut Creek near Best ${ }^{\mathrm{k}}$ & 9.71 & $1955-63$ & 16 & 0 & 1.2 & .7 & 2.4 & 2.0 & 1.8 \\
\hline 354 & 02089240 & Bear Creek near La Grange ${ }^{a}$ & 49.2 & $\begin{array}{l}1954-66,1968, \\
1970\end{array}$ & 23 & 0 & 1.1 & 6.3 & 11.3 & 9.3 & 9.0 \\
\hline 360 & 02089380 & Falling Creek at Falling Creek & 45.4 & 1949-55, 1957 & 19 & 0 & 1.2 & 1.7 & 5.8 & 4.1 & 4.0 \\
\hline 362 & 02089580 & Deep Run at Deep Run ${ }^{\mathrm{a}}$ & 6.1 & $\begin{array}{l}1949-54,1956-57 \\
1966\end{array}$ & 18 & 0 & 1.1 & .2 & 1.4 & .8 & .8 \\
\hline 363 & 02089620 & Southwest Creek near Woodington & 37.7 & $1956-57,1959-66$ & 16 & 1 & 1.2 & .3 & 3.1 & 2.2 & 1.6 \\
\hline 368 & 02089690 & Stonyton Creek near Graingers ${ }^{\mathrm{a}}$ & 36 & $\begin{array}{l}1954,1956-57 \\
1965-68,1970-71\end{array}$ & 14 & 1 & 1.1 & $<.05$ & .6 & .2 & .2 \\
\hline 369 & 02089730 & Mosley Creek near Grifton & 45.7 & $\begin{array}{l}1954-55,1957 \\
1964-68,1971\end{array}$ & 10 & 1 & 1.2 & .1 & .9 & .4 & .5 \\
\hline 372 & 02089946 & Moccasin Creek near Zebulon ${ }^{\mathrm{a}}$ & 29.8 & $\begin{array}{l}1950-54,1957-58 \\
1963,1966\end{array}$ & 20 & 1 & 1.1 & .09 & 2.6 & 1.4 & 1.2 \\
\hline 384 & 02090360 & Turkey Creek near Connor & 74.2 & $\begin{array}{l}1958,1965-68 \\
1971-73\end{array}$ & $13^{b}$ & 1 & 1.1 & .05 & 1.8 & .8 & .6 \\
\hline 395 & 02090507 & $\begin{array}{l}\text { Hominy Swamp at SR } 1321 \text { at } \\
\text { Wilson }\end{array}$ & 1.5 & $1969-70,1972-73$ & 7 & 1 & 1.1 & $0^{\mathrm{g}}$ & $\mathrm{N} / \mathrm{A}^{\mathrm{g}}$ & $\mathrm{N} / \mathrm{A}^{\mathrm{g}}$ & $\mathrm{N} / \mathrm{A}^{\mathrm{g}}$ \\
\hline 396 & 02090509 & $\begin{array}{l}\text { Hominy Swamp at U.S. 264A at } \\
\text { Wilson }\end{array}$ & 5.35 & $1969-70,1972-73$ & 9 & 2 & 1.1 & 0 & 0.09 & 0 & $<0.05$ \\
\hline
\end{tabular}


Table 7. Magnitude and frequency of annual low-flow characteristics at selected partial-record measuring sites in the Neuse River Basin, North Carolina-Continued

$\left[\mathrm{mi}^{2}\right.$, square mile; water years, the annual period from October 1 to September 30 and identified by the year in which the period ends; $\left(\mathrm{ft}^{3} / \mathrm{s}\right) / \mathrm{mi}^{2}$, cubic foot per second per square mile; $\mathrm{ft}^{3} / \mathrm{s}$, cubic foot per second; <, less than; SR, secondary road; N/A, not available]

\begin{tabular}{|c|c|c|c|c|c|c|c|c|c|c|c|}
\hline \multirow{2}{*}{ 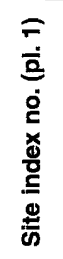 } & \multirow{2}{*}{ 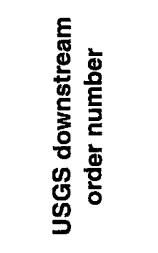 } & \multirow[b]{2}{*}{ Station name } & \multirow{2}{*}{ 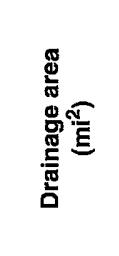 } & \multirow{2}{*}{$\begin{array}{l}\text { Period of } \\
\text { record } \\
\text { (water years) }\end{array}$} & \multicolumn{2}{|c|}{$\begin{array}{l}\text { Number of } \\
\text { measure- } \\
\text { ments }\end{array}$} & \multirow{2}{*}{ 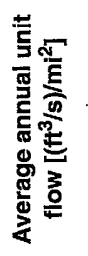 } & \multicolumn{4}{|c|}{$\begin{array}{l}\text { Low-flow characteristics } \\
\qquad\left(\mathrm{ft}^{3} / \mathrm{s}\right)\end{array}$} \\
\hline & & & & & $\frac{3}{4}$ & $\begin{array}{l}\frac{3}{0} \\
\frac{0}{2} \\
\text { 융 } \\
\text { N }\end{array}$ & & 웅 & ఫ્ & $\frac{0}{0}$ & ฮี \\
\hline 406 & 02090580 & Black Creek near Black Creek & 32.1 & $1955-59,1961-64$ & 17 & 6 & 1.1 & 0 & .2 & .05 & 0 \\
\hline 408 & 02090590 & Great Swamp near Black Creek & 38.8 & $\begin{array}{l}1958,1965-68 \\
1971\end{array}$ & 9 & 0 & 1.1 & 0 & .3 & .09 & $<.05$ \\
\hline 410 & 02090620 & Aycock Swamp near Stantonsburg & 11.5 & $\begin{array}{l}1958,1965-68 \\
1971\end{array}$ & 9 & 0 & 1.1 & 0 & .4 & .2 & .07 \\
\hline 413 & 02090634 & $\begin{array}{l}\text { Contentnea Creek near } \\
\text { Stantonsburg }\end{array}$ & 389 & $\begin{array}{l}1969-70,1972-74 \\
1978,1980-85\end{array}$ & 32 & 0 & 1.1 & 2.6 & 23.5 & 12.4 & 12.4 \\
\hline 417 & 02090720 & Toisnot Swamp near New Hope & 30 & $\begin{array}{l}1932,1954,1957- \\
59,1961-64,1969\end{array}$ & 19 & 0 & 1.1 & 2.5 & 5.2 & 4.7 & 4.0 \\
\hline 427 & 02090960 & Nahunta Swamp near Pikeville & 19 & $1957,1961-73$ & 22 & 0 & 1.2 & .6 & 2.6 & 2.2 & 1.7 \\
\hline 431 & 02090980 & The Slough near Saulston & 21.3 & $1957,1960-66$ & 12 & 0 & 1.2 & .8 & 3.6 & 3.1 & 2.4 \\
\hline 433 & 02091040 & Nahunta Swamp near Snow Hill & 90 & $\begin{array}{l}1949-54,1957 \\
1967-68\end{array}$ & 20 & 0 & 1.2 & 2.8 & 13.5 & 11.5 & 8.7 \\
\hline 435 & 02091241 & $\begin{array}{l}\text { Contentnea Creek at U.S. } 258 \text { at } \\
\text { Snow Hill }\end{array}$ & 694 & $\begin{array}{l}1969-70,1972-74 \\
1978,1980\end{array}$ & 10 & 0 & 1.2 & 25.8 & 88.2 & 51.7 & 61.2 \\
\hline 437 & 02091480 & Rainbow Creek near Glenfield & 12 & $1954-57,1960-65$ & $13^{!}$ & 0 & 1.2 & 1.4 & 2.8 & 2.2 & 2.3 \\
\hline 441 & 02091544 & Wheat Swamp near Hugo ${ }^{a}$ & 20.5 & $1956-57$ & 4 & 1 & 1.2 & .3 & 1.8 & 1.3 & 1.2 \\
\hline 443 & 02091574 & Contentnea Creek near Hugo & 789 & $\begin{array}{l}1956-57,1969-70 \\
1973-74\end{array}$ & 10 & 0 & 1.1 & 33.1 & 107 & 64.3 & 75.5 \\
\hline 449 & 02091664 & $\begin{array}{l}\text { Little Contentnea Creek at NC } 121 \\
\text { near Farmville }\end{array}$ & 55.1 & $\begin{array}{l}1956,1969-70 \\
1972,1974\end{array}$ & 10 & 0 & 1.2 & $<.05$ & 1.7 & .5 & .6 \\
\hline 456 & 02091740 & $\begin{array}{l}\text { Little Contentnea Creek at } \\
\text { Scuffleton }\end{array}$ & 172 & $\begin{array}{l}1956-57,1965-66 \\
1969-70,1980\end{array}$ & 14 & 0 & 1.2 & .2 & 10.0 & 2.9 & 4.0 \\
\hline 460 & 02091814 & Neuse River near Fort Barnwell & 3,900 & $\begin{array}{l}1970,1972-73, \\
1976,1978,1980- \\
82,1985-91 \\
1995-96\end{array}$ & 30 & 0 & 1.1 & 400 & 855 & 570 & 675 \\
\hline 461 & 02091820 & Core Creek near Fort Barnwell & 59 & $1949-58$ & 22 & 0 & 1.1 & .5 & 2.3 & 1.2 & 1.5 \\
\hline 468 & 02091910 & Swift Creek near Coxville & 78.2 & $\begin{array}{l}1956-57,1960-70 \\
1974-75\end{array}$ & 27 & 0 & 1.1 & .2 & 3.2 & 1.0 & 1.2 \\
\hline 486 & 0209218190 & $\begin{array}{l}\text { Trent River at NC } 11 \text { near Deep } \\
\quad \text { Run }\end{array}$ & 3.2 & $1974-76,1980-84$ & 34 & 1 & 1.2 & .1 & .5 & .3 & .3 \\
\hline 490 & 02092230 & Joshua Creek near Combs Fork & 12.1 & $1965-68,1970-71$ & 9 & 1 & 1.2 & $0^{\mathrm{g}}$ & $\mathrm{N} / \mathrm{A}^{\mathrm{g}}$ & $\mathrm{N} / \mathrm{A}^{\mathrm{g}}$ & $\mathrm{N} / \mathrm{A}^{\mathrm{g}}$ \\
\hline 492 & 02092290 & Rattlesnake Branch near Comfort & 2.5 & $\begin{array}{l}1954,1957,1961- \\
71\end{array}$ & $14^{\mathrm{c}}$ & 2 & 1.3 & $0^{\mathrm{g}}$ & $N / A^{g}$ & $\mathrm{~N} / \mathrm{A}^{\mathrm{g}}$ & $N / A^{g}$ \\
\hline 496 & 02092520 & Vine Swamp near Kinston & 6.30 & $\begin{array}{l}1954,1957,1961- \\
71\end{array}$ & $13^{\mathrm{c}}$ & 2 & 1.2 & $0^{\mathrm{g}}$ & $\mathrm{N} / \mathrm{A}^{\mathrm{g}}$ & $N / A^{g}$ & $\mathrm{~N} / \mathrm{A}^{\mathrm{g}}$ \\
\hline 497 & 02092540 & $\begin{array}{l}\text { Beaver Creek near Phillips } \\
\text { Crossroads }\end{array}$ & 33 & $\begin{array}{l}1956-57,1960-68 \\
1970\end{array}$ & 20 & 0 & 1.2 & .2 & 1.1 & .4 & .5 \\
\hline 498 & 02092549 & Musselshell Creek near Trenton & 9.7 & $\begin{array}{l}1954,1957,1965- \\
68,1970-71\end{array}$ & 10 & 1 & 1.2 & $<0.05$ & 1.8 & 0.9 & 0.8 \\
\hline
\end{tabular}


Table 7. Magnitude and frequency of annual low-flow characteristics at selected partial-record measuring sites in the Neuse River Basin, North Carolina-Continued

$\left[\mathrm{mi}^{2}\right.$, square mile; water years, the annual period from October 1 to September 30 and identified by the year in which the period ends; $\left(\mathrm{ft}^{3} / \mathrm{s}\right) / \mathrm{mi}^{2}, \mathrm{cubic}$ foot per second per square mile; $\mathrm{ft}^{3} / \mathrm{s}$, cubic foot per second; <, less than; SR, secondary road; N/A, not available]

\begin{tabular}{|c|c|c|c|c|c|c|c|c|c|c|c|}
\hline \multirow{2}{*}{ 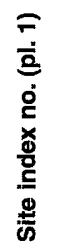 } & \multirow{2}{*}{ 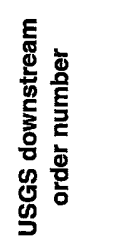 } & \multirow[b]{2}{*}{ Station name } & \multirow{2}{*}{ 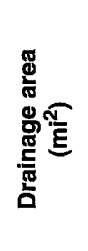 } & \multirow{2}{*}{$\begin{array}{c}\text { Period of } \\
\text { record } \\
\text { (water years) }\end{array}$} & \multicolumn{2}{|c|}{$\begin{array}{c}\text { Number of } \\
\text { measure- } \\
\text { ments }\end{array}$} & \multirow{2}{*}{ 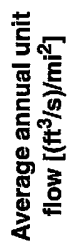 } & \multicolumn{4}{|c|}{$\begin{array}{l}\text { Low-flow characteristics } \\
\qquad\left(\mathrm{ft}^{3} / \mathbf{s}\right)\end{array}$} \\
\hline & & & & & $\frac{3}{\frac{3}{4}}$ & $\begin{array}{l}\frac{3}{0} \\
\frac{0}{6} \\
\text { o } \\
\text { N }\end{array}$ & & 응 & ซี & $\begin{array}{l}\frac{0}{0} \\
\frac{5}{3}\end{array}$ & ฐี \\
\hline 505 & 02092590 & Upper Broad Creek near Olympia & 21 & $1950-54,1956-59$ & 14 & 6 & 1.2 & $0^{\mathrm{g}}$ & $\mathrm{N} / \mathrm{A}^{\mathrm{g}}$ & $\mathrm{N} / \mathrm{A}^{\mathrm{g}}$ & $\mathrm{N} / \mathrm{A}^{\mathrm{g}}$ \\
\hline 506 & 02092620 & $\begin{array}{l}\text { Upper Broad Creek tributary near } \\
\text { Grantsboro }\end{array}$ & 3.0 & $1957-58,1961-73$ & $15^{\mathrm{c}}$ & I & 1.2 & $0^{\mathrm{g}}$ & $N / A^{g}$ & $\mathrm{~N} / \mathrm{A}^{\mathrm{g}}$ & $\mathrm{N} / \mathrm{A}^{\mathrm{g}}$ \\
\hline
\end{tabular}

${ }^{a}$ Low-flow characteristics previously published in Giese and Mason (1993). Where different, estimates in this report supersede the previous estimates.

${ }^{b}$ Low-flow characteristics based on combined partial-record measurements at 02084890 (site 5) and 02084896 (site 6). Initially, 25 measurements are available in the combined record of discharges; however, four measurements were made on concurrent dates resulting in 21 measurements used in the analyses. Discharges at site 6 were adjusted by drainage area prior to analyses.

${ }^{\mathrm{c}}$ Record of measurements consists mostly of crest-gage (flood) discharges, which limit the determination of estimates for all low-flow characteristics. At site 45 , record of four zero-flow discharges in combination with small drainage basin $\left(1.00 \mathrm{mi}^{2}\right)$ suggests that all low-flow characteristics are zero flow. At other indicated sites, only zero-flow $7 \mathrm{Q} 10$ discharge can be estimated.

${ }^{\mathrm{d}}$ Discharge measurements were made in conjunction with water-quality sampling at site.

e Site now inundated by impoundment; low-flow characteristics represent pre-impoundment conditions.

${ }^{\mathrm{f}}$ Low-flow characteristics reflect pre-impoundment flow conditions prior to regulation by Falls Lake upstream from station.

g Estimates for all low-flow characteristics cannot be determined based on available data; however, multiple observations of zero flow at site or zeroflow 7Q10 discharge at downstream site allow estimate of zero-flow 7Q10 at indicated site.

${ }^{\mathrm{h}}$ Site operated as continuous-record gaging station since May 1996. Low-flow characteristics based on combined partial-record measurements at 02087359 (site 236) and 02087355 (site 233).

${ }^{\mathrm{i}}$ Drainage area revised to $41.8 \mathrm{mi}^{2}$ (table 5 ) when site and road were relocated upstream from a tributary draining to original location. Original drainage area used when performing flow analyses. Low-flow characteristics reflect streamflow conditions prior to construction of Lake Wheeler.

${ }^{\mathrm{j}}$ Low-flow characteristics based on combined partial-record measurements at 02088270 (site 306) and 02088275 (site 307).

${ }^{\mathrm{k}}$ Site now in backwater of dam located 0.5 mile downstream; low-flow characteristics represent flow conditions prior to existence of dam.

${ }^{1}$ Low-flow characteristics based on combined partial-record measurements at 02091480 (site 437) and 02091486 (site 438).

flow characteristics, as well as sites where low-flow characteristics previously have been published or for which knowledge of low-flow discharges were necessary in the development of discharge profiles.

Discharge measurements at the partial-record measuring sites were plotted with concurrent flows at nearby index sites, typically continuous-record gaging stations where low-flow characteristics had been determined (fig. 8). Correlation plots were then examined to determine if a relation exists between the concurrent flows. Index sites for possible use in the correlation analysis of concurrent flows were selected by using several factors, including proximity of the partial-record and index sites, as well as similarity in such basin characteristics as drainage area and topography.

Defining the relation between concurrent flows is usually based on either statistical techniques or graphical interpretation whereby visually fitted lines are drawn between the concurrent flows (Riggs, 1972). In this investigation, both statistical and graphical methods were used to establish the relation between the concurrent flows. When applying the statistical method, the Maintenance of Variance Extension (MOVE.1) technique was used as opposed to the leastsquares regression technique, which has been shown to provide biased estimates of low-flow characteristics (Stedinger and Thomas, 1985). As a general rule, computed MOVE. 1 relations having correlation coefficients greater than 0.8 were used to derive the estimates of low flows. For cases in which the correlation coefficient was less than 0.8 or the relation was nonlinear, visually fit correlations were applied to more adequately describe the relation between concurrent flows.

At most partial-record measuring sites, correlations of the discharge measurements with concurrent flows at multiple index sites yielded several 


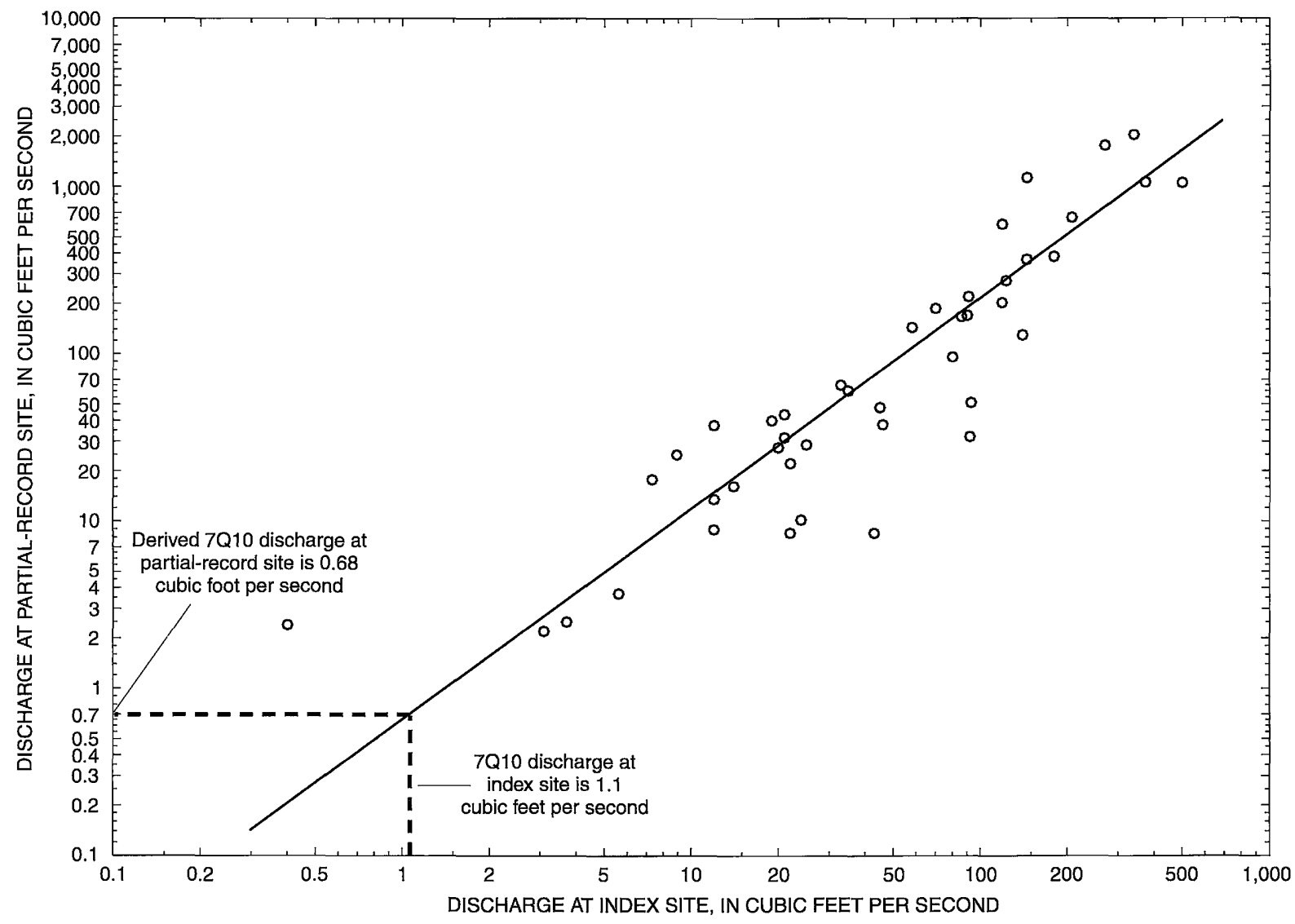

Figure 8. Correlation of concurrent discharge at partial-record site at Mill Creek near Cox Mill (site 307) and at the index site at Little Coharie Creek near Roseboro (Cape Fear River Basin).

relations from which estimates of low-flow discharges could be determined. From each relation, estimates of low-flow discharges were derived from the individual correlation plot. Thus, to determine overall estimates of low-flow discharges (7Q10, 30Q2, W7Q10, and 7Q2) for each partial-record measuring site, individual estimates derived from each correlation were averaged. However, individually derived estimates from poor correlations, where visually fit lines could not be established or otherwise were deemed suspect, were not included in the average for overall estimates.

Low-flow characteristics for the partial-record measuring sites reflect unregulated conditions with the exception of one site on the Neuse River. Low-flow discharges listed for site 460 during the period following the 1982 water year reflect regulated conditions from Falls Lake (table 7). However, because the ratio of drainage area at site 460 to that at the dam is slightly greater than 5.0, the effects of regulation may be nonexistent. Additionally, backwater effects from tidal influences downstream from site 460 may also affect flows. For the remaining partial-record measuring sites listed in table 7 , the presence of minor regulation and/or flow diversions in the record of discharge measurements is not documented. However, discharge measurements at some of these sites most likely reflect some effects of flow modifications, particularly at such streams as Crabtree Creek, Swift Creek (Wake County), Little River, and Contentnea Creek.

As previously discussed, the Neuse River Basin includes parts of 6 of the 10 HA's identified by Giese and Mason (1993). Regional equations are available for computing low-flow characteristics at sites within HA5. Giese and Mason (1993) identified HA5 as part of the Raleigh Belt, a zone of metamorphic and intrusive rocks which includes a predominance of felsic metaigneous, felsic gneiss, and schist rock units. Further, they noted that streams in HA5 have higher unit low flows than those in the surrounding HA's of the Coastal Plain (HA1 and HA2) and the eastern and central Piedmont (HA4 and HA6). Low-flow 
characteristics based on the regional equations for HA5 are computed by using the drainage area for the site of interest, and Giese and Mason (1993) reported that the standard errors of estimates range from 49 percent (30Q2 equation) to 92 percent (7Q10 equation).

Low-flow characteristics based on regional equations at 10 partial-record measuring sites in HA5 in the Neuse River Basin and analysis of partial-record data as previously outlined (table 7) are presented in table 8. Differences between the regional estimates and data estimates vary among the 10 sites listed. Five of the 10 sites $(146,159,200,209$, and 245) have regional estimates that are lower than the data estimates. The remaining five sites have higher regional estimates than the data estimates; the most significant differences, ranging from nearly 600 to 700 percent, are noted at site 178 on Crabtree Creek. For most sites, differences between the low-flow characteristics can be attributed to the general nature of residual errors associated with use of a statistical regression to compute estimates. At site 178 on Crabtree Creek, however, use of the HA5 regional equations does not account for part of the basin's presence within the adjacent HA6 (Triassic basin). As depicted on the map of hydrologic areas by Giese and Mason (1993), site 178 occurs within HA5. However, the headwaters of this $52.2-\mathrm{mi}^{2}$ basin begin in HA6, a factor which is not reflected in the regional estimates but is reflected in the lower data estimates. Still, the regional equations provided by Giese and Mason (1993) are useful for computing estimates at locations where no other data are available to assess low-flow characteristics. Further, their conclusions regarding relatively higher unit low flows in the part of HA5 that lies within the Neuse River Basin are confirmed by the increased unit low flows from Durham and western Wake Counties to central and eastern Wake County.

Table 8. Low-flow characteristics for partial-record measuring sites and regional equations in Hydrologic Area 5 (HA5) (Giese and Mason, 1993) within the Neuse River Basin, North Carolina

$\left[\mathrm{mi}^{2}\right.$, square mile; water years, the annual period from October 1 to September 30 and identified by the year in which the period ends; $\mathrm{ft}^{3} / \mathrm{s}$, cubic foot per second. First line of low-flow characteristics are those listed in table 7 for the indicated site. The second line of low-flow characteristics are based on the regional equations (computed to two significant figures) presented for HA5 in Giese and Mason (1993)]

\begin{tabular}{|c|c|c|c|c|c|c|c|c|}
\hline \multirow{2}{*}{ 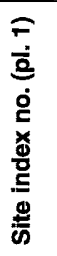 } & \multirow{2}{*}{ 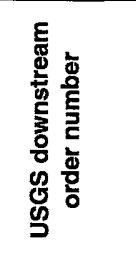 } & \multirow[b]{2}{*}{ Station name } & \multirow[b]{2}{*}{ 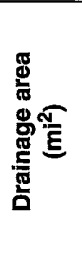 } & \multirow[b]{2}{*}{$\begin{array}{c}\text { Period of } \\
\text { record } \\
\text { (water years) }\end{array}$} & \multicolumn{4}{|c|}{$\begin{array}{l}\text { Low-flow characteristics } \\
\left(\mathrm{ft}^{3} / \mathrm{s}\right)\end{array}$} \\
\hline & & & & & $\frac{0}{0}$ & ซ్ల & $\frac{0}{\frac{0}{0}}$ & ฮั \\
\hline 140 & 02087187 & Richland Creek at NC 98 at Wake Forest & 7.66 & $1972-74$ & $\begin{array}{l}0.5 \\
.58\end{array}$ & $\begin{array}{l}2.2 \\
1.7\end{array}$ & $\begin{array}{l}1.6 \\
1.3\end{array}$ & $\begin{array}{l}1.5 \\
1.2\end{array}$ \\
\hline 146 & 02087194 & Austin Creek at Wake Forest & 3.98 & $1958-59,1968$ & $\begin{array}{l}.1 \\
.41\end{array}$ & $\begin{array}{l}1.6 \\
1.0\end{array}$ & $\begin{array}{l}.7 \\
.80\end{array}$ & $\begin{array}{l}.8 \\
.74\end{array}$ \\
\hline 159 & 02087220 & Harris Creek near Wake Crossroads & 9.85 & $1954-59,1961-64$ & $\begin{array}{l}1.0 \\
.66\end{array}$ & $\begin{array}{l}3.2 \\
2.1\end{array}$ & $\begin{array}{l}2.3 \\
1.6\end{array}$ & $\begin{array}{l}2.1 \\
1.5\end{array}$ \\
\hline 178 & 02087251 & Crabtree Creek near Cary & 52.2 & $\begin{array}{l}1961-62,1968,1982- \\
92,1995-96\end{array}$ & $\begin{array}{r}.2 \\
1.6\end{array}$ & $\begin{array}{l}1.2 \\
8.4\end{array}$ & $\begin{array}{r}.8 \\
6.1\end{array}$ & $\begin{array}{r}.8 \\
5.5\end{array}$ \\
\hline 195 & 02087270 & Hare Snipe Creek near Millbrook & 7.22 & $1961-68,1970$ & $\begin{array}{l}.2 \\
.56\end{array}$ & $\begin{array}{l}1.2 \\
1.6\end{array}$ & $\begin{array}{r}.8 \\
1.3\end{array}$ & $\begin{array}{r}.7 \\
1.2\end{array}$ \\
\hline 200 & 02087290 & Mine Creek near Millbrook & 8.87 & $\begin{array}{l}1951-55,1958,1961- \\
\quad 62,1968\end{array}$ & $\begin{array}{l}.8 \\
.62\end{array}$ & $\begin{array}{l}3.2 \\
1.9\end{array}$ & $\begin{array}{l}2.4 \\
1.5\end{array}$ & $\begin{array}{l}2.4 \\
1.4\end{array}$ \\
\hline 209 & 02087320 & Big Branch near Millbrook & 3.78 & $\begin{array}{l}1951-55,1958,1961- \\
\quad 62,1968\end{array}$ & $\begin{array}{l}.7 \\
.40\end{array}$ & $\begin{array}{c}1.8 \\
.96\end{array}$ & $\begin{array}{c}1.4 \\
.77\end{array}$ & $\begin{array}{c}1.4 \\
.71\end{array}$ \\
\hline 245 & 02087410 & Poplar Creek near Knightdale & 8.83 & $\begin{array}{l}1954-58,1960,1963, \\
1970\end{array}$ & $\begin{array}{l}.9 \\
.62\end{array}$ & $\begin{array}{l}3.2 \\
1.9\end{array}$ & $\begin{array}{l}2.5 \\
1.5\end{array}$ & $\begin{array}{l}2.4 \\
1.4\end{array}$ \\
\hline 262 & 02087610 & Swift Creek near McCullers & 55.2 & $1932,1949-53$ & $\begin{array}{r}.1 \\
1.6\end{array}$ & $\begin{array}{l}4.9 \\
8.8\end{array}$ & $\begin{array}{l}2.9 \\
5.2\end{array}$ & $\begin{array}{l}2.6 \\
4.7\end{array}$ \\
\hline 326 & 02088434 & $\begin{array}{l}\text { Buffalo Creek at Poole Road near } \\
\text { Wendell }\end{array}$ & 15.8 & $1955,1958,1972-74$ & $\begin{array}{l}.2 \\
.85\end{array}$ & $\begin{array}{l}1.5 \\
3.1\end{array}$ & $\begin{array}{r}.9 \\
2.4\end{array}$ & $\begin{array}{r}.9 \\
2.2\end{array}$ \\
\hline
\end{tabular}




\section{Occurrence of Zero or Minimal 7Q10 Discharge}

Estimated 7Q10 discharges at 61 of the 163 sites were determined to be zero (tables 6, 7). In addition to the sites having zero 7Q10 discharge, 11 sites have 7Q10 discharges reported to be less than $0.05 \mathrm{ft}^{3} / \mathrm{s}$. In a previous report on the low-flow characteristics in the Roanoke River Basin, Weaver (1996) defined minimal 7Q10 discharges as those reported to be less than $0.1 \mathrm{ft}^{3} / \mathrm{s}$, a threshold used by Giese and Mason (1993) in their reporting of low-flow characteristics for streams in North Carolina. In this report, minimal 7Q10 discharges have been re-defined to a lower threshold of $0.05 \mathrm{ft}^{3} / \mathrm{s}$, the minimum flow allowed by DWQ in its evaluation of NPDES permits.

When the sites in the Neuse River Basin were arranged in order of ascending drainage area, there was no clear indication of a maximum drainage area below which 7Q10 discharges are generally zero. The sites having zero or minimal 7Q10 discharges were combined and plotted on a map to determine what other factors, if any, may account for the low potential to sustain base flow. Estimates of zero or minimal 7Q10 discharges occur in two general sections of the study area-in the upper end of the Neuse River Basin in Orange, Person, Durham, Granville, and western Wake Counties and in the lower end of the study area in Jones, Craven, Pamlico, and Pitt Counties. In the central section of the study area, occurrences of zero or minimal 7Q10 discharges were noted, though in a more scattered pattern than in the upper and lower ends of the basin. The areas of the basin where zero or minimal 7Q10 discharges could be expected for small- to midsize basins are identified on plate 1 (shaded areas).

In the upper end of the study area, the presence of poorly drained soils - that is, soils having low infiltration rates - is a primary factor in numerous occurrences of zero 7Q10 discharges. This part of the study area is composed of tributaries draining to the Neuse River upstream from its confluence with New Light Creek (partially inundated by Falls Lake) downstream of the Wake-Durham County line (pl. 1). Also included in this area are the headwaters of Crabtree Creek, Swift Creek, and Walnut Creek in western Wake County. Not all soils in this upper end of the basin are classified as poorly drained (fig. 6B). Some moderately drained soils occurring in parts of Orange and Person Counties within the Neuse River Basin also are characterized as having infiltration rates in the lower range among the soil hydrologic groups.
An additional factor that may be considered at sites underlain by moderately drained soils in this area is the average annual rainfall amounts which increase from west to east across the basin (fig. 5B). Much of the water that comes in contact with the soils in this area most likely enters the streams as overland runoff and does not infiltrate into surficial aquifers for later release during drought conditions. Among sites having zero 7 Q10 discharges, the drainage areas range from less than $0.01 \mathrm{mi}^{2}$ (site 10) to about $44 \mathrm{mi}^{2}$ (site 121). For sites in this area having non-zero $7 \mathrm{Q} 10$ discharges, the average 7Q10 unit low flow is about $0.005\left(\mathrm{ft}^{3} / \mathrm{s}\right) / \mathrm{mi}^{2}$. Therefore, sites with drainage areas less than about 10 $\mathrm{mi}^{2}$ could be expected to have zero or minimal 7Q10 discharges (less than $0.05 \mathrm{ft}^{3} / \mathrm{s}$ ). Within the HA's delineated by Giese and Mason (1993), the upper end of the study area occurs within HA7 and HA6 (fig. 2) where they reported drainage areas of $3 \mathrm{mi}^{2}$ and $45 \mathrm{mi}^{2}$, respectively, as those drainage areas below which $7 \mathrm{Q} 10$ discharges generally are zero. Giese and Mason's (1993) drainage-area threshold for HA6 is comparable to the range of drainage areas $\left(10.1 \mathrm{mi}^{2}\right.$ to $\left.44.2 \mathrm{mi}^{2}\right)$ for sites $(105,107$, and 121) within the portion of this area underlain by the Triassic basin and which have been observed to have 7Q10 discharges equal to zero.

Likewise, in Jones, Craven, Pamlico, and Pitt Counties in the lower end of the study area, the extensive cover of poorly drained soils and low topographic relief likely accounts for the presence of sites having zero or minimal 7Q10 discharges. For sites in this area having non-zero $7 \mathrm{Q} 10$ discharges, the average 7Q10 unit low flows is about $0.01\left(\mathrm{ft}^{3} / \mathrm{s}\right) / \mathrm{mi}^{2}$. Therefore, sites with drainage areas less than about $5 \mathrm{mi}^{2}$ could be expected to have zero or minimal 7Q10 discharges (less than $0.05 \mathrm{ft}^{3} / \mathrm{s}$ ). The lower end of the study area is within HA1 (clay soils) and HA2 (sandy soils) with soils of HA1 tending to be predominant (Giese and Mason, 1993). For HA1 and HA2, Giese and Mason reported drainage areas of $35 \mathrm{mi}^{2}$ and $2 \mathrm{mi}^{2}$, respectively, as those below which 7Q10 discharges generally are zero. On tributaries which drain to the Neuse River downstream from its confluence with Contentnea Creek (pl. 1), eight sites having drainage areas ranging from $2.5 \mathrm{mi}^{2}$ (site 492) to $27 \mathrm{mi}^{2}$ (site 471) were determined to have zero $7 \mathrm{Q} 10$ discharges. Of these eight sites, six are located on streams tributary to Swift Creek and the Trent River, two large tributaries to the Neuse River in the lower end of the study area. Aside from poorly drained soils, the land-surface slope in the lower part of the Coastal Plain physiographic 
province is also a likely factor in the occurrence of zero or minimal 7Q10 discharges. The presence of little or no relief results in streams that have very little slope for moving flow downstream. This observation is consistent with the conclusions of Giese and Mason (1993) in which streams in the Coastal Plain have very low potential for sustained base flow.

Assessing the occurrence of zero or minimal 7Q10 discharges in the central section of the study area is more complex. This large area is composed of streams draining to the Neuse River between its confluences with New Light Creek (Wake County) and Contentnea Creek (pl. 1). The dominant soils in this area are well and moderately drained (fig. 6B). Even though categorized as moderately drained soils, occurrences of soils having some poor drainage (A/C group, table 3) are present in the Black Creek and Hannah Creek Basins from extreme southern Wake County into southern Johnston County. Other occurrences of poorly drained soils are present along reaches of the Neuse River, Contentnea Creek, and along other smaller streams draining basins known to be swamp terrain. Sites having a 7Q10 discharge of zero and large drainage areas $(288,301,406,408$, and 410) mostly occur in the basins occupied by poorly drained soils or characterized as swamp. Among the sites in this area of moderately and well-drained soils having zero or minimal 7Q10 discharges, drainage areas range from about $1 \mathrm{mi}^{2}$ (site 154) to nearly $82 \mathrm{mi}^{2}$ (site 288, Black Creek subbasin). Because many other sites in this area with drainage areas in this same range have 7Q10 discharges exceeding minimal levels (greater than $0.05 \mathrm{ft}^{3} / \mathrm{s}$ ), it is difficult to identify areas that may be considered "zero-flow" zones. Where poorly drained soils are the predominant factor at sites in the upper and lower ends of the study area, the magnitudes of low flows in the central section appear to be affected by a combined set of factors which include soils, degree of terrain slope, and drainage area.

Assessing the potential for the 7Q10 discharge being zero in the central section of the study area will, for a given site, require an examination of the low-flow characteristics listed for nearby sites (tables 6,7).

\section{DISCHARGE PROFILES FOR SELECTED STREAMS IN THE NEUSE RIVER BASIN}

Discharge profiles of low flows were developed for the Neuse River and selected tributaries to the Neuse River. The tributaries, which vary in basin size and characteristics, include Perry Creek, Walnut Creek (Wake County), Poplar Creek, Swift Creek (Wake and Johnston Counties), Little River, Walnut Creek (Wayne County), Contentnea Creek, Swift Creek (Pitt and Craven Counties), and the Trent River. Drainage-area profiles also were developed for each of these streams to document the relation between basin size and lowflow characteristics.

River miles shown on the profiles were determined by using the USEPA's River Reach Files (Bondelid and others, 1990), which are GIS coverages of rivers and streams. The coverages, digitized from 1:100,000-scale USGS topographic maps, provide a comprehensive representation of the hydrology in a given area. River mileages computed for each stream begin at zero at the mouth and increase upstream toward the headwaters.

Profiles are presented for the 7Q10, 30Q2, W7Q10, and 7Q2 low-flow discharges. Low-flow characteristics (tables 6,7 ) for streams where profiles were developed serve as anchor points in the discharge profiles. These points serve as references for computing other low-flow discharges at upstream and downstream locations. Low-flow discharges at the ungaged locations on the profile were determined by linear interpolation between the nearest upstream and downstream anchor points. Profiles developed for Perry Creek, Poplar Creek, and Walnut Creek (Wayne County) show only one anchor point, and low-flow discharges at the ungaged locations on the profile were 
determined by using the unit low flows for the site at the anchor point. For each of these profiles, comparison of the unit low flows at the anchor point and nearby sites on other streams where low-flow characteristics have been determined yielded favorable comparison and thus provided a basis for using the unit low flows at the anchor point for estimating low flows at the ungaged locations. For the Walnut Creek (Wake County), Swift Creek (Pitt and Craven Counties), and Trent River profiles, low-flow discharges estimated for some sites are not included in the compilation of lowflow characteristics (tables 6, 7). For these cases, available records of discharge were used to estimate low flows to assist in the development of the profiles. While deemed reliable for the purposes of developing profiles, the estimates are not included in the compilation of low-flow characteristics pending confirmation of estimates through collection and analyses of additional records of discharge. Because these estimates are not included in the compilations, anchor points were not used on the low-flow discharge profiles at these sites.

Low flows from tributaries were estimated where the increase in drainage area from a tributary was 5 percent or greater of the drainage area immediately upstream from the tributary. Exceptions to this are for Swift Creek (Pitt-Craven Counties) and Trent River; many sites on tributaries in these basins exhibit zerovalue 7Q10 discharges and, as discussed in later sections, receive ground-water discharge from an underlying aquifer.

Profiles for the Neuse River, Contentnea Creek, Trent River, and both Swift Creeks include actual measurements of discharge obtained synoptically at multiple points along streams. Streamflows at selected locations on these streams were measured in September 1997 during a period of extended dry conditions. The profiles of actual measurements provide a "snapshot" of the conditions when flows in many streams were at or near 30Q2 or 7Q2 discharge conditions. Discharges at unmeasured locations between the measured points are linearly interpolated.

Changes in flow caused by impoundments and instream withdrawals and point-source discharges (table 2) were not noted on the discharge profiles. Where a point-source discharge occurs, the ratio of the discharge amount to the 7Q10 discharge generally is insignificant, except for some of the smaller basins profiled in this report. Furthermore, and more importantly, a point-source discharge usually is preceded by a withdrawal at a nearby upstream location. Analysis of these withdrawals and associated major point-source discharges indicated that the ratio of net loss of flow (between withdrawal and discharge points) to 7Q10 discharge is usually insignificant.

No profiles for Crabtree Creek were developed in this report. Crabtree Creek drains $146 \mathrm{mi}^{2}$ of central Wake County where land-use cover is highly urbanized as a result of growth in the City of Raleigh. Low-flow characteristics are presented for two gaging stations on Crabtree Creek (sites 188 and 212; table 6). Unit low flows between the two gaging stations increase by factors ranging from two to four. This increase in unit low flows reflects the transition from poorly drained soils of the Triassic basin in western Wake County to moderately drained soils weathered from granitic rocks underlying much of central and eastern Wake County (fig. 6). Further, flows in Crabtree Creek include an NPDES point-source discharge having a permitted flow of nearly $7 \mathrm{ft}^{3} / \mathrm{s}(4.45 \mathrm{Mgal} / \mathrm{d})$. The low-flow characteristics presented in table 6 have been adjusted to remove the effects of these point-source discharges and, thus, represent "natural-flow" conditions at the two gaging stations. Provided that streamflow monitoring continues at the two existing gaging stations, a better understanding of the low-flow characteristics in Crabtree Creek will permit a more accurate assessment of the changes in unit low flows in this highly urbanized area and possibly permit future development of discharge profiles for Crabtree Creek. 


\section{Perry Creek}

Perry Creek drains nearly $12 \mathrm{mi}^{2}$ of central Wake County and flows directly into the Neuse River (pl. 1). Land use in this small basin has become urban as a result of rapidly expanding municipal influences from the City of Raleigh. The drainage-area profile was developed for the 3.7-mi reach of Perry Creek between a continuous-record gaging station at site 153 and the mouth of the creek (fig. 9A). The total length of Perry Creek is about $5.7 \mathrm{mi}$. Several unnamed tributaries contribute flow to Perry Creek, and a small number of lakes are located on Perry Creek, the largest of which is Greshams Lake.

Continuous records of streamflow at two gaging stations (sites 153 and 154) were used in the development of low-flow discharge profiles for Perry
Creek (fig. 9B). The 7Q10 discharge at the mouth of Perry Creek is about $0.9 \mathrm{ft}^{3} / \mathrm{s}$. Unit low flows at site 153 are very similar to unit low flows at nearby sites and, thus, were used to develop the estimates of low flows depicted in the profiles. The unit low flows reflect a relatively high potential for sustaining base flows and are characteristic of streams in most of central Wake County, which is underlain by moderately drained soils. The effects of small lakes on low flows in Perry Creek, if any, are not evident from the profiles. No known minimum releases exist for the lake. NPDES records provided by DWQ indicate that a point-source discharge having a permitted flow of nearly $0.04 \mathrm{ft}^{3} / \mathrm{s}$ (0.025 Mgal/d) enters Perry Creek via Greshams Lake. From the profile, the 7Q10 discharge for Perry Creek just upstream from the dam is estimated at about $0.25 \mathrm{ft}^{3} / \mathrm{s}$ (fig. 9B). 

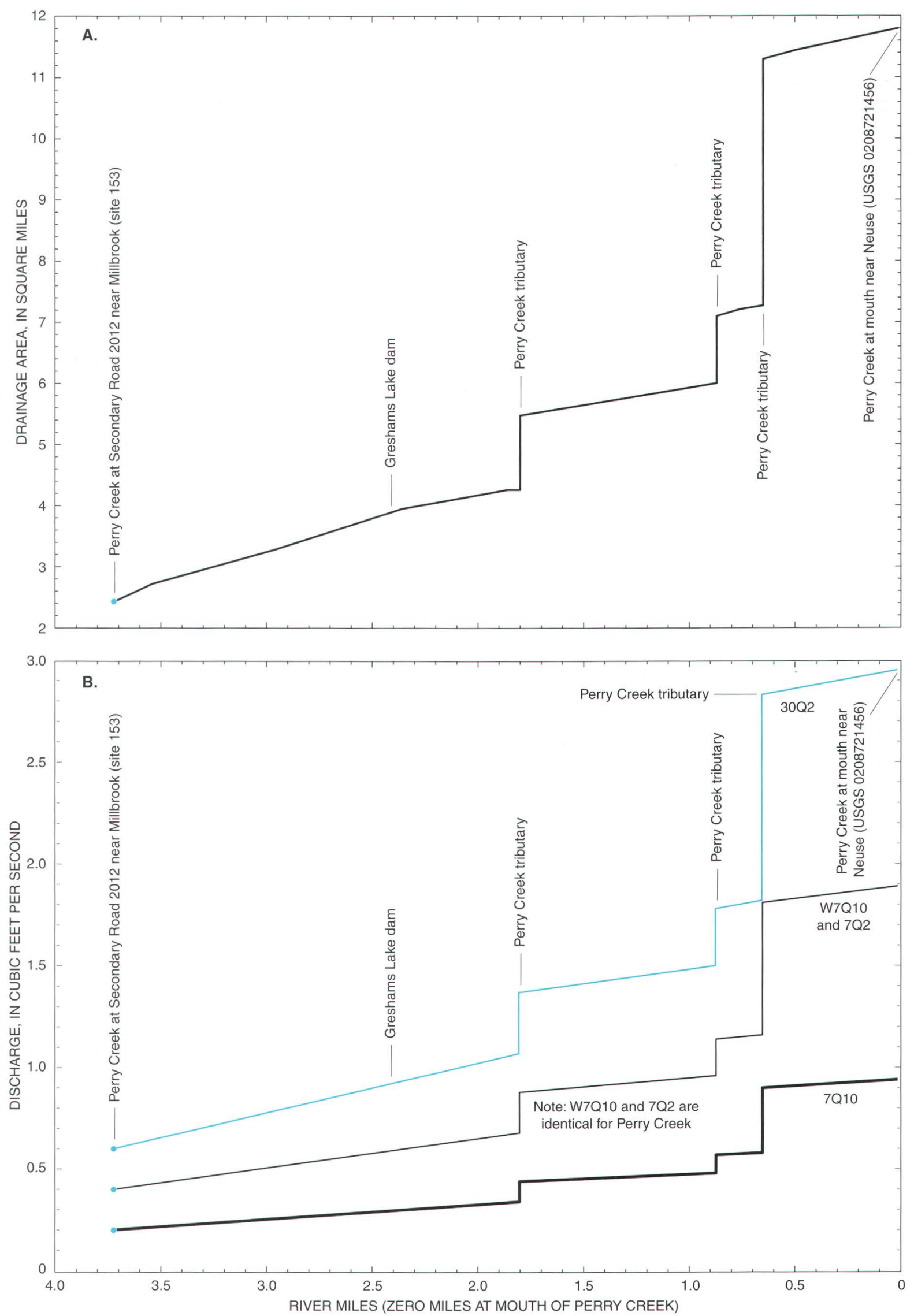

Figure 9. Relation of river miles to (A) drainage area and (B) low-flow discharges for Perry Creek. 


\section{Walnut Creek (Wake County)}

Walnut Creek drains $46 \mathrm{mi}^{2}$ in south-central Wake County and is a tributary of the Neuse River (pl. 1). The drainage-area profile depicts the reach of Walnut Creek between site 224 (river mile 14.9) and the mouth (fig. 10A). Walnut Creek is about $18 \mathrm{mi}$ in total length. Tributaries to Walnut Creek include Simmons Branch, Bushy Branch, Rocky Branch, Wildcat Branch, and Big Branch, which is the largest tributary $\left(12 \mathrm{mi}^{2}\right.$ or about 26 percent of the Walnut Creek Basin). Land use in the basin is mostly urban and suburban because of the stream's location in the Cary and southern Raleigh municipalities.
Partial-record discharges at four sites $(224,228$, 236, and 241) on Walnut Creek were analyzed to determine low-flow characteristics for use in developing discharge profiles. As previously discussed, some low-flow estimates used in the development of profiles are not included in the compilation of low-flow characteristics (tables 6, 7). Estimates for sites 224, 228, and 241 were used only for development of the profiles for Walnut Creek; low-flow characteristics at site 236 are listed in table 7 and denoted by the anchor point on the profiles (fig. 10B).

Low-flow discharge profiles for Walnut Creek represent a stream in which unit low flows change from relatively low to higher values between the headwaters and mouth (fig. 10B). The headwaters of Walnut Creek

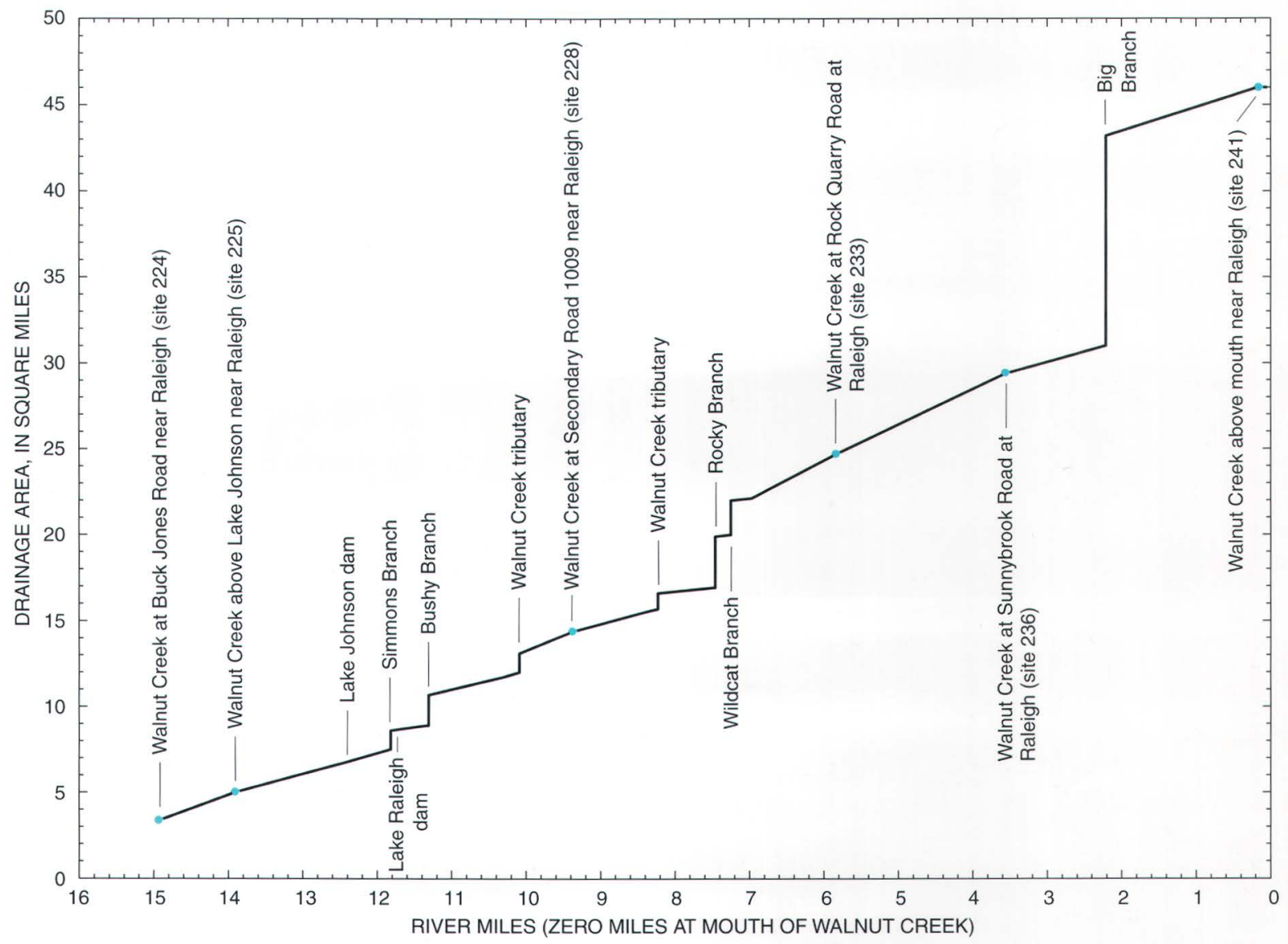

Figure 10A. Relation of river miles to drainage area for Walnut Creek (Wake County). 


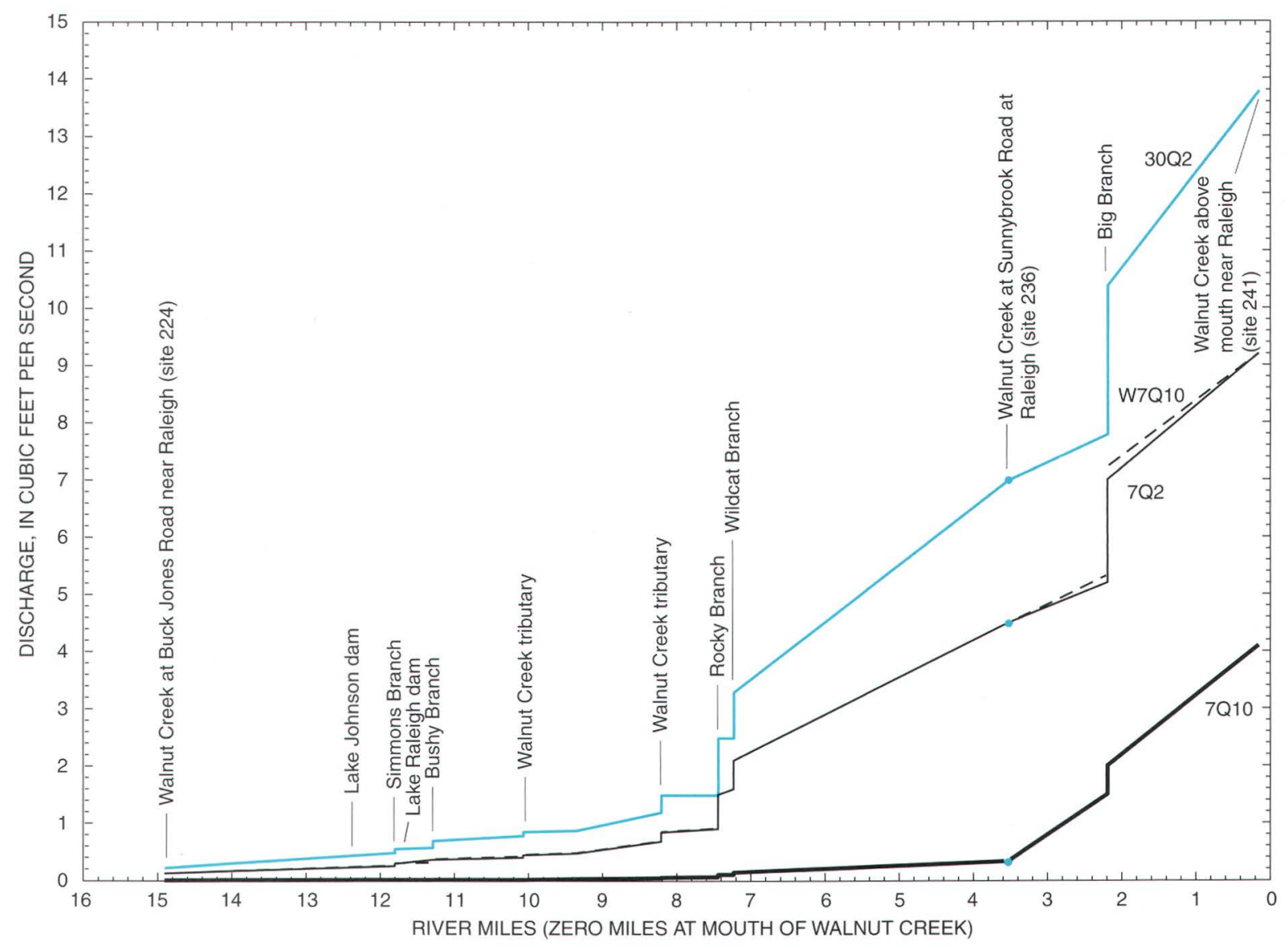

Figure 10B. Relation of river miles to low-flow discharges for Walnut Creek (Wake County).

are close to the boundary between the poorly drained soils of the Triassic basin and the moderately drained soils weathered from granitic rocks underlying much of Wake County (fig. 6). Hence, flows in the upper reaches of Walnut Creek have a relatively low potential for sustained base flows. Lake Johnson and Lake Raleigh, two impoundments with no known minimum release, also are located in the upper reaches of Walnut Creek. As Walnut Creek winds along its course to the mouth, the potential for sustained base flows increases significantly, as depicted in the changing slopes shown on the discharge profiles (fig. 10B). Between site 228 (river mile 9.4) and the mouth, the 7Q10 discharge increases from less than $0.05 \mathrm{ft}^{3} / \mathrm{s}$ to slightly more than $4 \mathrm{ft}^{3} / \mathrm{s}$ (fig. 10B). In this same reach, the drainage area increases from about 14 to $46 \mathrm{mi}^{2}$; this is equivalent to an increase of unit low flows from 0.003 to $0.087\left(\mathrm{ft}^{3} / \mathrm{s}\right) / \mathrm{mi}^{2}$. NPDES records indicate that two point-source discharges enter Walnut Creek in the vicinity of site 233 (pl. 1). However, total permitted flows from these discharges are less than $0.01 \mathrm{ft}^{3} / \mathrm{s}$ compared to the 7Q10 discharge of $0.2 \mathrm{ft}^{3} / \mathrm{s}$ for Walnut Creek at site 233 , estimated from the low-flow profile (fig. 10B). 


\section{Poplar Creek}

Poplar Creek is $9 \mathrm{mi}^{2}$ in basin size at its mouth in southeastern Wake County and enters the Neuse River just upstream from the point where the Neuse River crosses into Johnston County (pl. 1). Poplar Creek is approximately $5.7 \mathrm{mi}$ in total length; the drainage-area profile for this stream shows the increases in basin size from about river mile 4.0 to the mouth (fig. 11A).

Low-flow discharge profiles indicate that Poplar Creek is a stream having relative high potential for sustained base flows (fig. 11B). As with Perry Creek, the unit low flows are attributed to the moderately drained soils weathered from granitic rocks underlying much of Wake County (fig. 6). The unit low flows for partial-record measuring site 245 on Poplar Creek are similar in value to the average of the unit low flows at nearby partial-record measuring sites in Wake County. Hence, the unit low flows at site 245 were used to compute the low-flow characteristics at all locations on Poplar Creek. Records of NPDES point-source discharges identify three permits for discharges into Poplar Creek. The total of the permitted flows is about $0.4 \mathrm{ft}^{3} / \mathrm{s}$ compared to the 7Q10 discharge $\left(0.9 \mathrm{ft}^{3} / \mathrm{s}\right.$, table 7) at site 245 just upstream from the mouth. One point-source discharge has a permitted flow of $0.125 \mathrm{Mgal} / \mathrm{d}$ (nearly $0.2 \mathrm{ft}^{3} / \mathrm{s}$, table 2 ) and is located at site 244. From the low-flow profile, the estimated 7Q10 discharge for Poplar Creek at site 244 is $0.55 \mathrm{ft}^{3} / \mathrm{s}$ (fig. 11B).

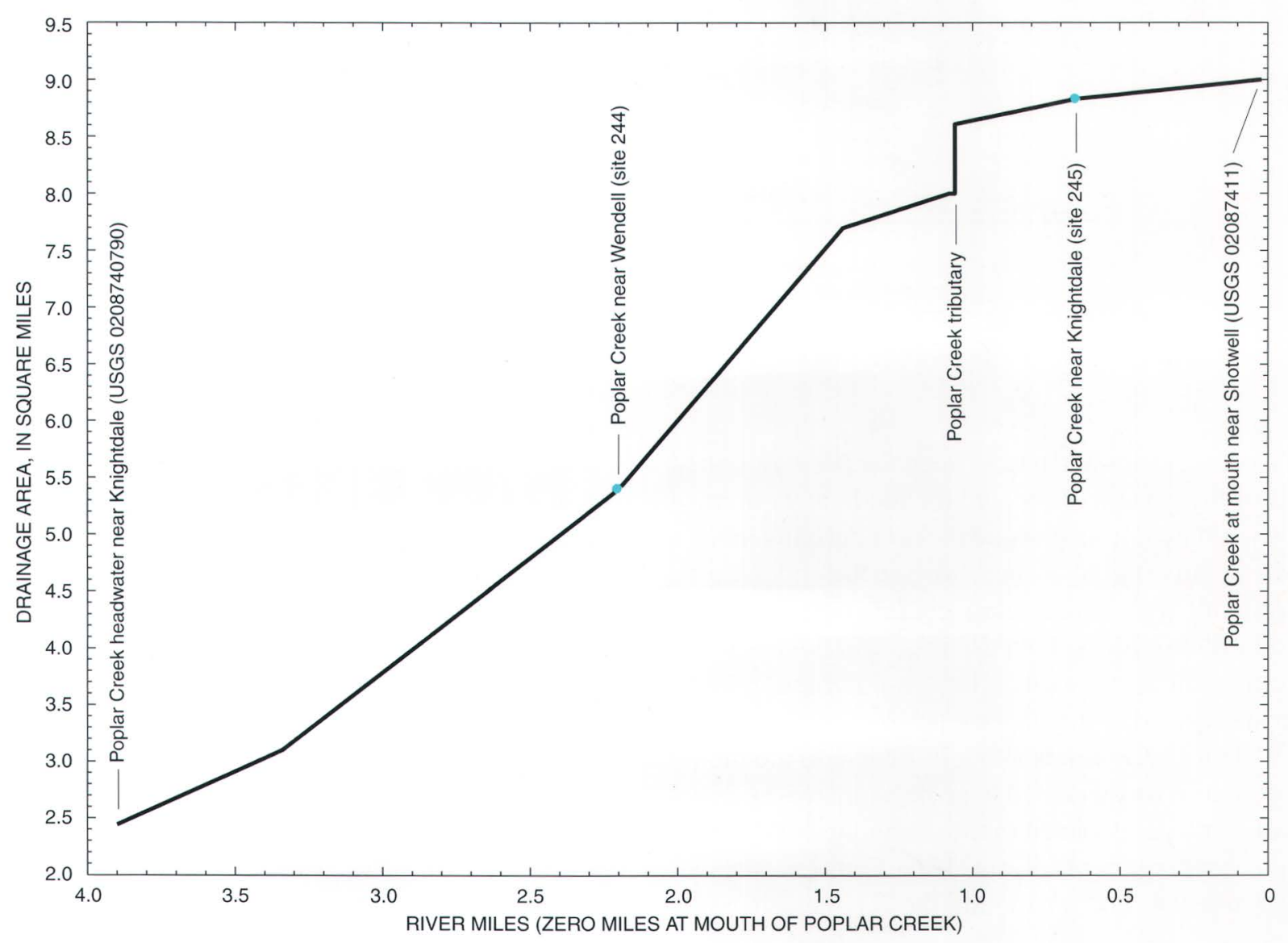

Figure 11A. Relation of river miles to drainage area for Poplar Creek. 


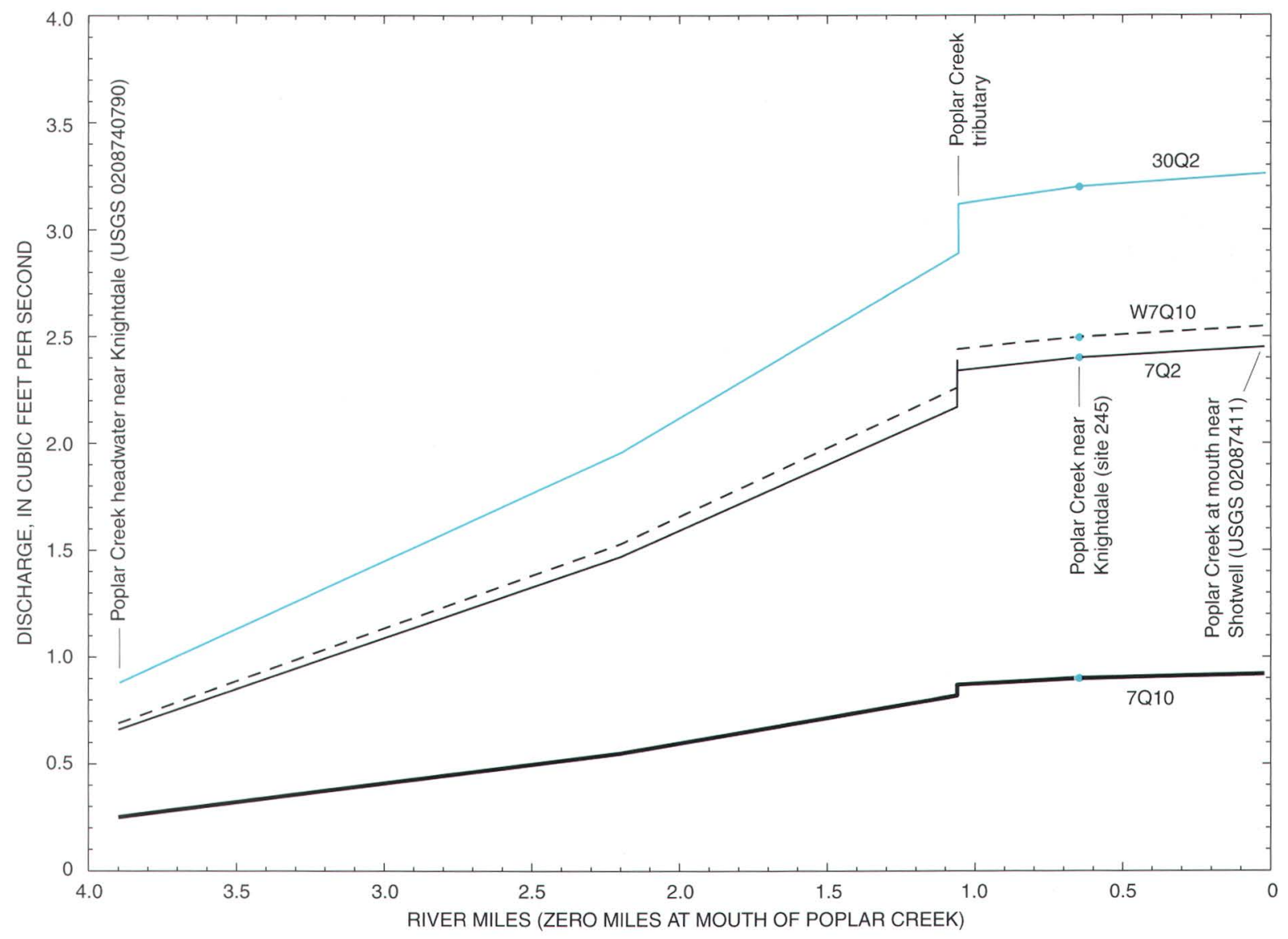

Figure 11B. Relation of river miles to low-flow discharges for Poplar Creek. 


\section{Swift Creek (Wake and Johnston Counties)}

Swift Creek drains parts of southern Wake and Johnston Counties with its headwaters originating between Apex and Cary (pl. 1). At its mouth near Smithfield, where Swift Creek drains into the Neuse River, the drainage area is $289 \mathrm{mi}^{2}$ (fig. 12A). The largest tributary to Swift Creek is Middle Creek, which contributes $132 \mathrm{mi}^{2}$ (45 percent) to Swift Creek just upstream from its mouth. Other tributaries to Swift Creek include White Oak Creek and Little Creek.

Similar to the profiles shown for Walnut Creek in Wake County, the low-flow discharge profiles for Swift Creek indicate that the potential for sustained base flows increases between the headwaters and mouth (fig. 12B). The headwaters of Swift Creek are close to the transitional area between the poorly drained soils of the Triassic basin and the moderately drained soils weathered from granitic rocks underlying much of Wake County (fig. 6). Therefore, flows in the upper reach have almost no potential for sustained 7Q10 discharges. Downstream from Lake Wheeler, low-flow profiles depict increasing flows and apparently reflect an area of relatively higher potential for sustained base flows. Existence of a transition area is further indicated by a profile of actual measurements obtained on September 23, 1997, at selected locations along Swift Creek. At the gaging station below Lake Wheeler (site 260), the measured discharge was $0.03 \mathrm{ft}^{3} / \mathrm{s}$, whereas the discharge measured at downstream site 265 below Lake Benson dam was $6.25 \mathrm{ft}^{3} / \mathrm{s}$ (fig. 12B). In this same reach, the drainage area increases from about 35.8 to $66.3 \mathrm{mi}^{2}$; this is equivalent to an increase of unit low flows from 0.0008 to $0.094\left(\mathrm{ft}^{3} / \mathrm{s}\right) / \mathrm{mi}^{2}$. From site 265 below Lake Benson downstream to other measured sites $(266,273)$, the slope of the measured-discharge profile indicates a small range in variation among the unit low flows, decreasing from about 0.09 to $0.07\left(\mathrm{ft}^{3} / \mathrm{s}\right) / \mathrm{mi}^{2}$.

Lake Wheeler and Lake Benson, which were constructed in 1957 and 1925, respectively (Powell, 1968), are impoundments of Swift Creek in Wake County. Currently, no minimum flow releases are required for either lake (James Mead, Division of Water Resources, written commun., 1998). Flow releases from Lake Wheeler and Lake Benson have not been subjected to active regulation and, thus, the dams operate as "run-of-river" structures. The low-flow profiles indicate that effects on low flows from each impoundment are different. While the dams at each impoundment have similar dimensional characteristics and flow-release capabilities, reductions in downstream flows below Lake Wheeler are more significant than those below Lake Benson.

Examination of daily mean discharges at site 260 below Lake Wheeler indicates numerous occurrences of zero flow. Low-flow characteristics at site 262 , based on discharges obtained prior to the construction of Lake Wheeler and thus not shown on low-flow profiles, further indicate a reduction in unit low flows as a result of the construction of the dam.

Records of NPDES point-source discharges identify four permits for Swift Creek and its tributaries in the vicinities of Lake Wheeler and Lake Benson. The total permitted flows among these permits is about $0.13 \mathrm{ft}^{3} / \mathrm{s}$ compared to the 7Q10 discharge of $0.3 \mathrm{ft}^{3} / \mathrm{s}$ at downstream site 266 near Drug Store (table 7). 


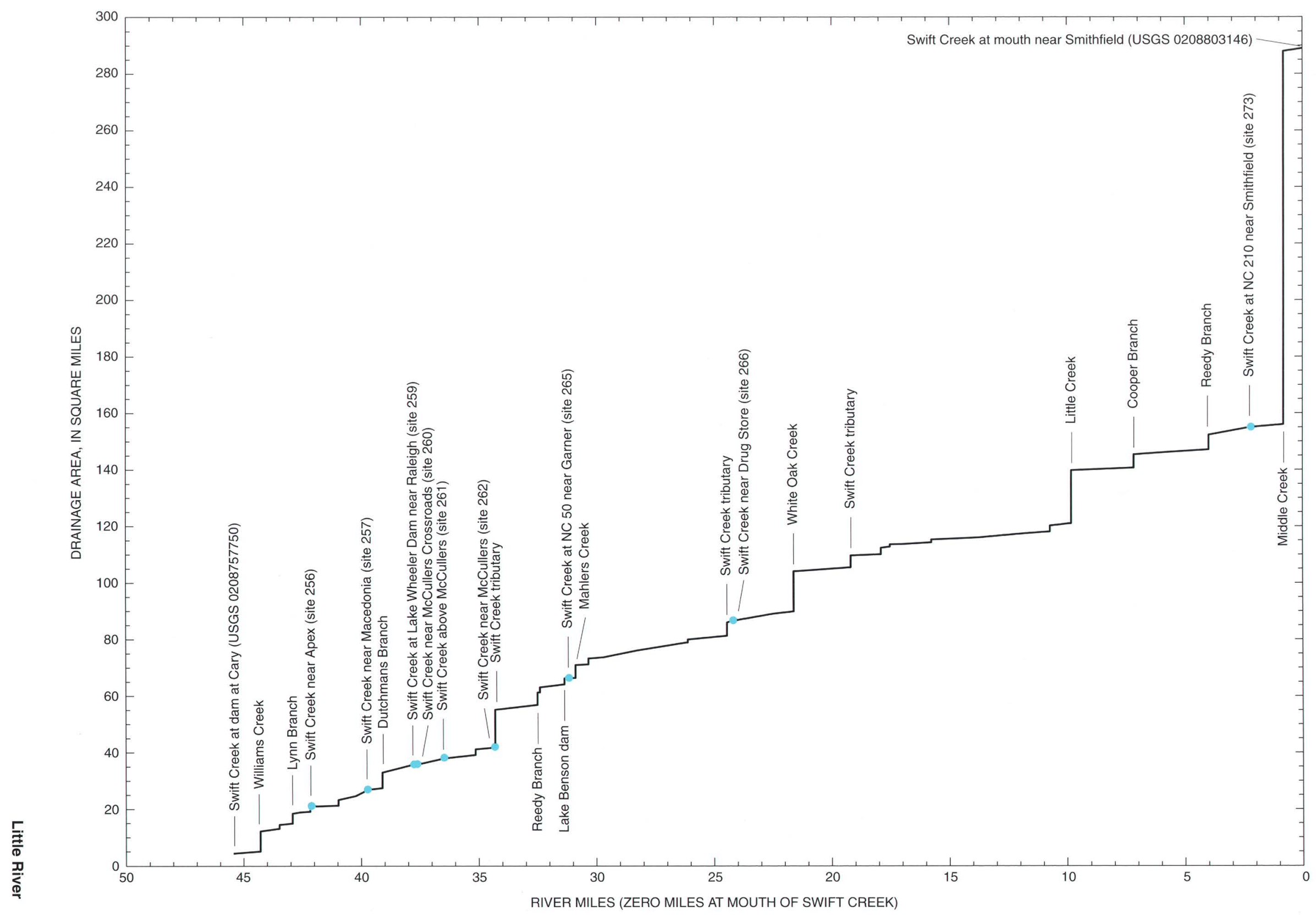

Figure 12A. Relation of river miles to drainage area for Swift Creek (Wake and Johnston Counties). 


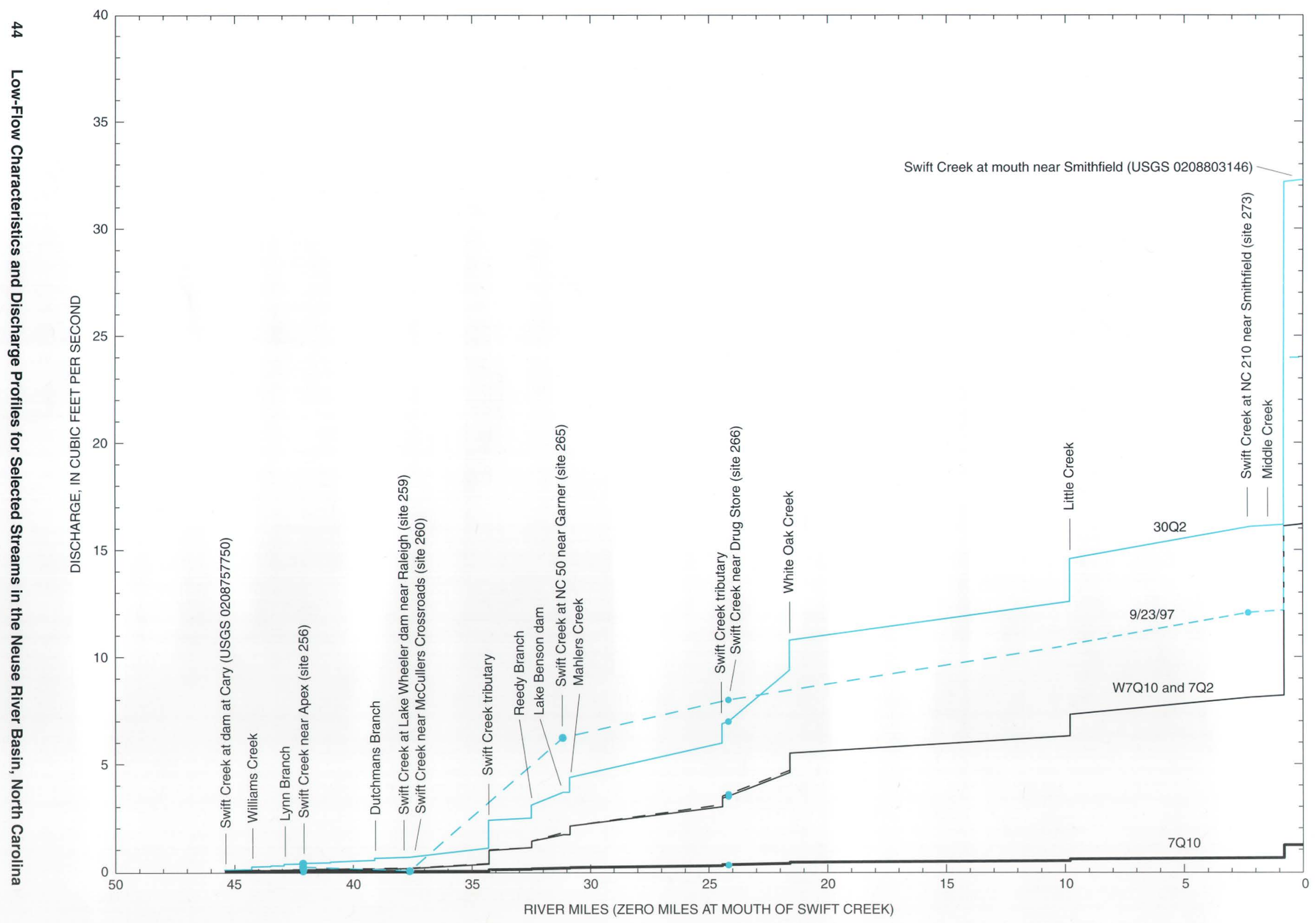

Figure 12B. Relation of river miles to low-flow discharges for Swift Creek (Wake and Johnston Counties). 


\section{Little River}

The Little River is the largest and last major tributary to enter the Neuse River within the upper Neuse River Basin (hydrologic unit 03020201) (fig. 4). About $85 \mathrm{mi}$ in total length, the river winds its way through Franklin, Wake, Johnston, and Wayne Counties before merging with the Neuse River just west of Goldsboro (pl. 1). The drainage area at the mouth is slightly more than $317 \mathrm{mi}^{2}$ (fig. 13A). The largest tributary to the Little River is Buffalo Creek; other significant tributaries include Little Buffalo Creek, Cattail Creek, Little Creek, Spring Branch, and Mill Creek.

Throughout most of its entire reach, the low-flow profiles for Little River reflect unit low flows that result in moderately to highly sustained base flows compared to the profiles for Walnut and Swift Creeks in Wake and Johnston Counties (fig. 13B). Unit low flows for 7Q10 discharges range from about $0.010\left(\mathrm{ft}^{3} / \mathrm{s}\right) / \mathrm{mi}^{2}$ at the headwaters to $0.016\left(\mathrm{ft}^{3} / \mathrm{s}\right) / \mathrm{mi}^{2}$ in the lower reaches just upstream from the mouth. Downstream from the gaging station at site 330 , overall slopes in the profiles increase significantly indicating increases in the unit low flows. The increases are attributed to the river's course through the Fall Line, an area of transition from the Piedmont Province to the Coastal Plain. The Fall Line is characterized by increased occurrences of rock outcrops and variations in channel slopes, which likely correspond to increases in unit low flows in the Little River.

Several small municipalities have flow diversions which occur in the Little River. In 1996, the Town of Zebulon withdrew an average of about 0.54 $\mathrm{Mgal} / \mathrm{d}\left(0.8 \mathrm{ft}^{3} / \mathrm{s}\right.$; table 2) from an impounded reach of the Little River upstream from site 322 (drainage area $55.0 \mathrm{mi}^{2}$, at approximately river mile 68). As indicated by the profile, this average withdrawal is equivalent to the estimated 7Q10 discharge in the reach upstream from this site (fig. 13B). Other flow diversions are point-source discharges from the Towns of Kenly and Princeton. The Town of Kenly is permitted to discharge up to about $0.52 \mathrm{Mgal} / \mathrm{d}\left(0.8 \mathrm{ft}^{3} / \mathrm{s}\right.$; table 2$)$ downstream from site 330 where the $7 \mathrm{Q} 10$ discharge is $1.6 \mathrm{ft}^{3} / \mathrm{s}$ (table 6). Likewise, Princeton is permitted to discharge up to about $0.275 \mathrm{Mgal} / \mathrm{d}\left(0.4 \mathrm{ft}^{3} / \mathrm{s}\right.$, table 2$)$ downstream of site 335 where the $7 \mathrm{Q} 10$ discharge is $2.5 \mathrm{ft}^{3} / \mathrm{s}$ (table 6). 


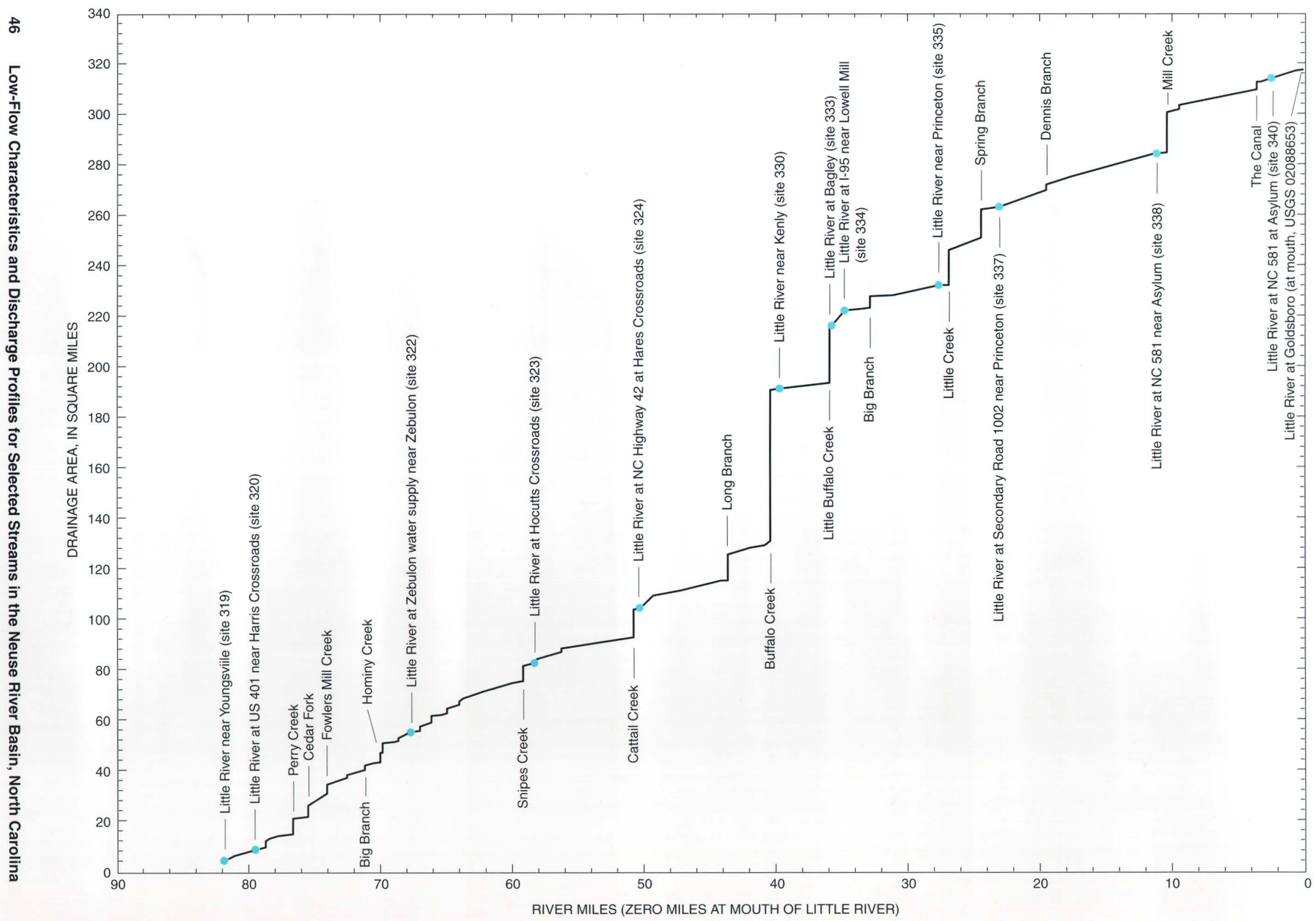

Figure 13A. Relation of river miles to drainage area for the Little River. 


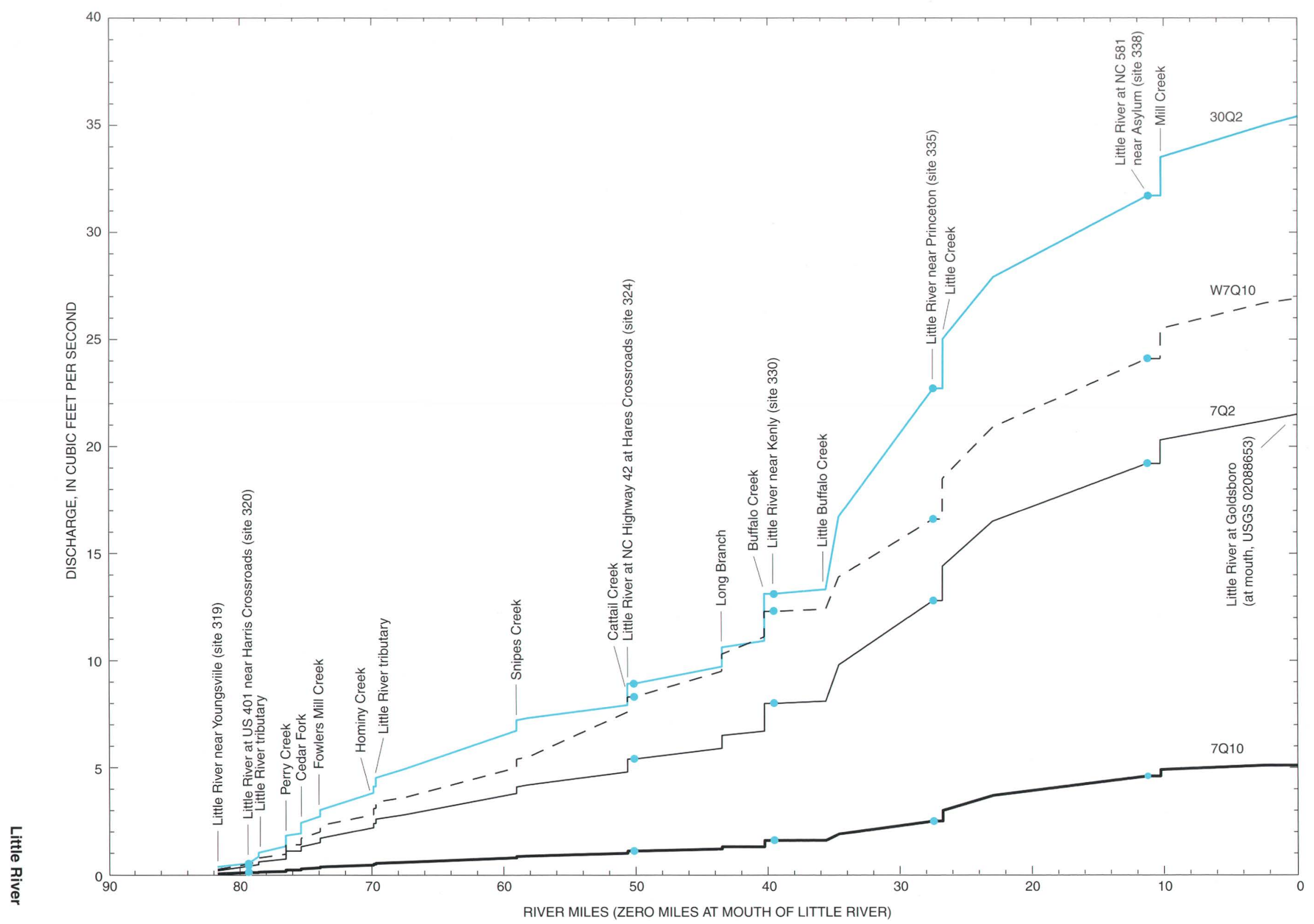

\&

Figure 13B. Relation of river miles to low-flow discharges for the Little River. 


\section{Walnut Creek (Wayne County)}

Walnut Creek drains slightly more than $20 \mathrm{mi}^{2}$ at its mouth where it flows into the Neuse River (pl. 1); the total length of Walnut Creek is about $8.3 \mathrm{mi}$. The drainage-area profile indicates the increases in basin size from river mile 5.5 to the mouth (fig. 14A). Mira Branch, the only tributary for which drainage-area information was available, enters Walnut Creek just downstream from the dam on Lake Wackena, a small impoundment of Walnut Creek.

Unit low flows at site 349 on Walnut Creek were used to determine the low-flow discharges at other locations on the stream (fig. 14B). The discharge measurements used to determine low-flow characteristics at site 349 (table 7) were obtained prior to the construction of Lake Wackena; thus, the lowflow profiles for Walnut Creek reflect the preimpoundment flow conditions in the stream. No minimum flow releases are known to exist for Lake
Wackena, and no further discharge measurements at locations downstream from the dam have been obtained since its construction. Thus, the effects of the impoundment on downstream low flows in Walnut Creek currently cannot be quantified. The average unit low flows at site 349 and other nearby sites in southeastern Wayne County and western Lenoir County were similar in value. The favorable comparison of average unit low flows from other sites to the unit low flows at site 349 suggest that low-flow profiles shown for Walnut Creek are representative of "natural-flow" conditions during droughts. Moderately and well-drained soils are present along Walnut Creek in parts of this subbasin (fig. 6A). According to NPDES records, there is one permitted discharge in the Walnut Creek Basin located downstream from site 350 . The permitted flow for this discharge is less than $0.1 \mathrm{ft}^{3} / \mathrm{s}$ compared to the $7 \mathrm{Q} 10$ discharge $\left(1.5 \mathrm{ft}^{3} / \mathrm{s}\right)$ estimated from the profile for the mouth of Walnut Creek (fig. 14B).

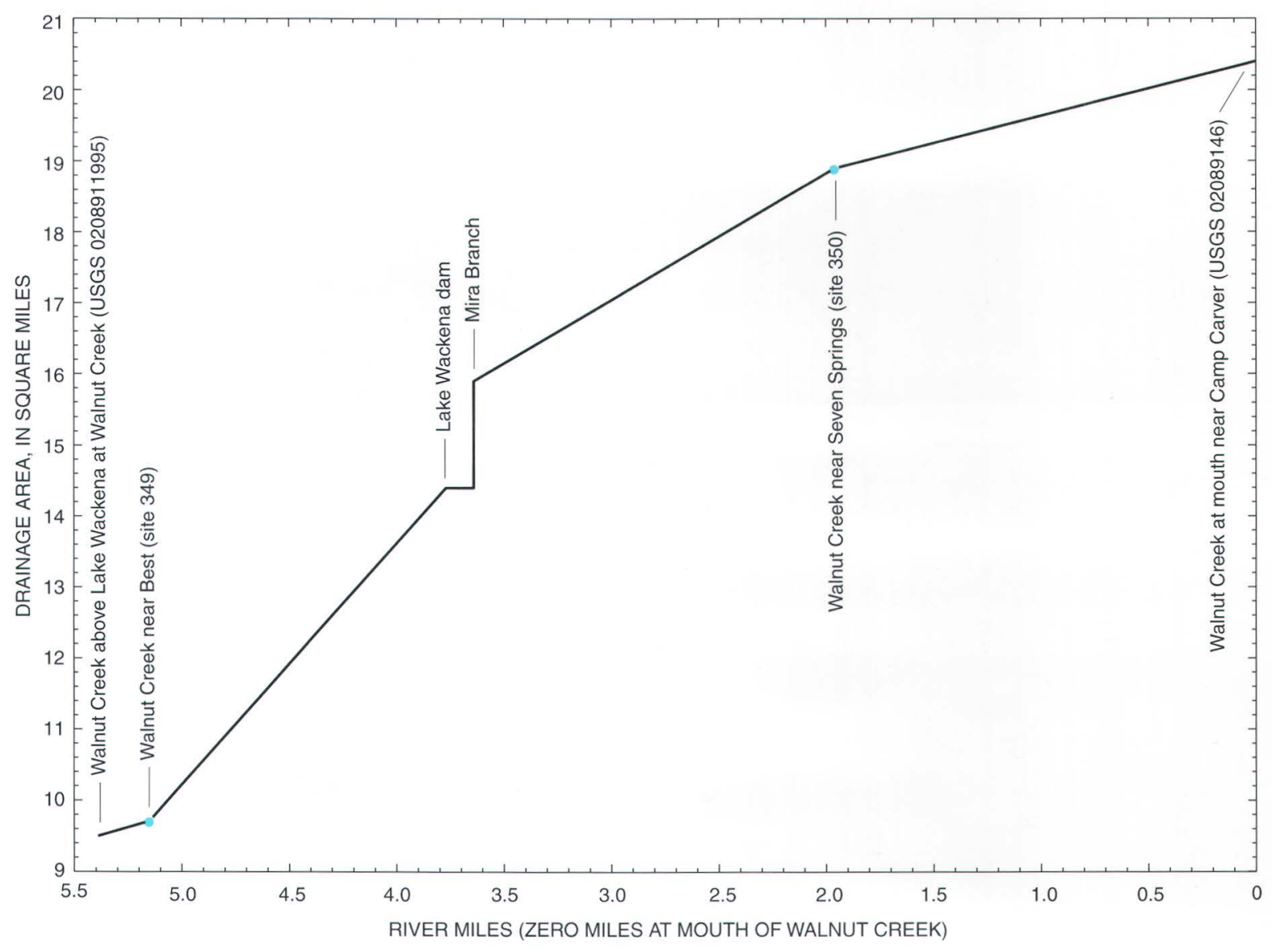

Figure 14A. Relation of river miles to drainage area for Walnut Creek (Wayne County). 


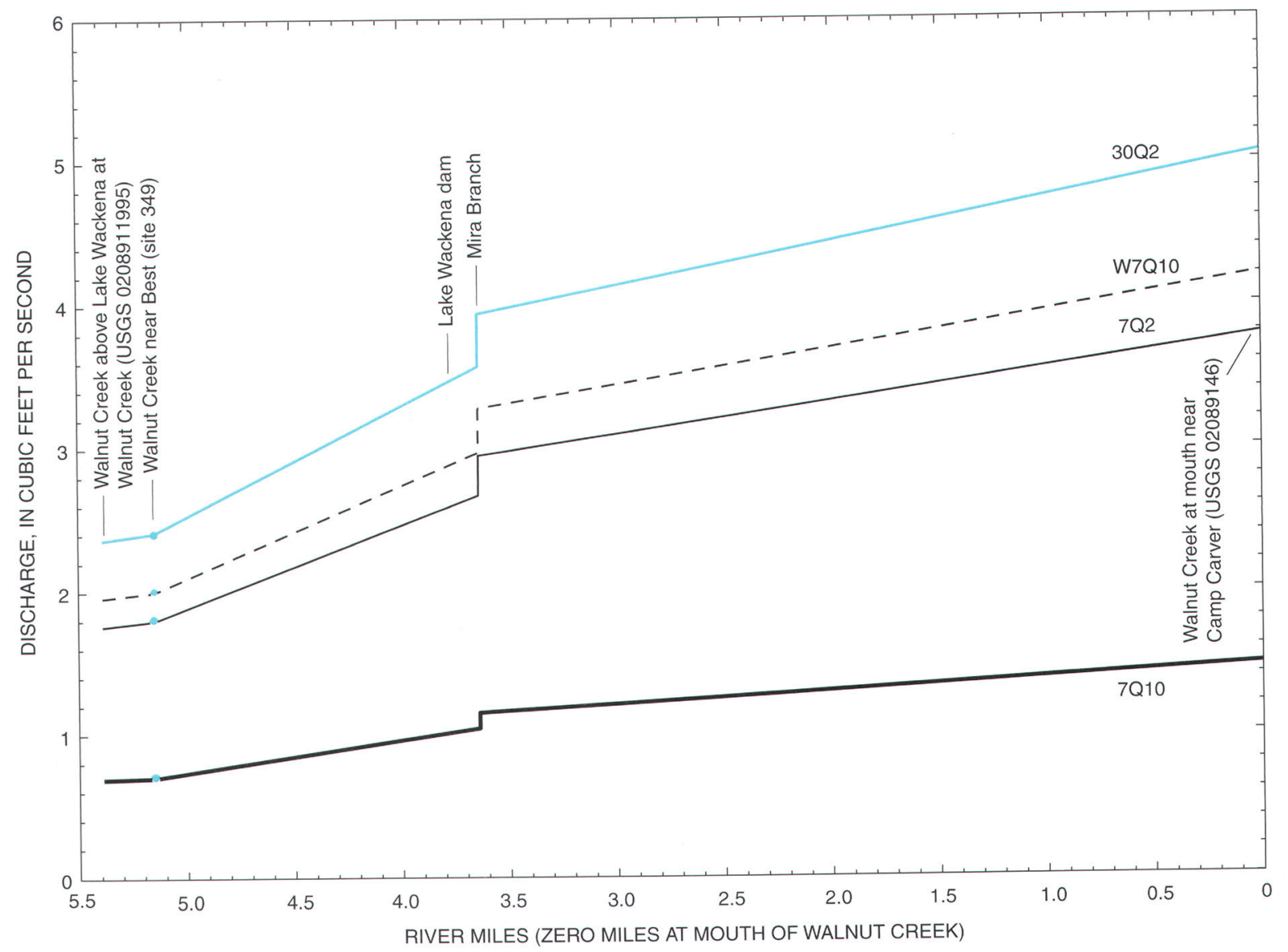

Figure 14B. Relation of river miles to low-flow discharges for Walnut Creek (Wayne County). 


\section{Contentnea Creek}

Contentnea Creek and its tributaries compose hydrologic unit 03020203 (fig. 4). At the mouth where it enters the Neuse River, the drainage area is $1,010 \mathrm{mi}^{2}$ (fig. 15A). Approximately $121 \mathrm{mi}$ in length, Contentnea Creek begins as Moccasin Creek in southern Franklin County. At the confluence of Moccasin Creek and Turkey Creek in Wilson County, the stream becomes known as Contentnea Creek (pl. 1). The largest tributary to Contentnea Creek is Little Contentnea Creek; other significant tributaries include Black Creek, Toisnot Swamp, and Nahunta Swamp. Two impoundments-Buckhorn Reservoir and Wiggins Mill Reservoir-are on Contentnea Creek in Wilson County and result in inundation of the river valley upstream from the dams. Buckhorn Reservoir, constructed in 1976, is the larger of the two reservoirs with a surface area of 750 acres and begins at the confluence of Moccasin Creek and Turkey Creek. Wiggins Mill Reservoir, formed in 1773 and previously known by various other names including Contentnea Lake (Powell, 1968), is located about $16 \mathrm{mi}$ downstream from Buckhorn Reservoir and has a surface area of about 200 acres (North Carolina Department of Environment, Health, and Natural Resources, 1992).

Low-flow profiles indicate the stream can be divided into three reaches, each having distinctly different potentials for sustained base flows (fig. 15B). The first reach is defined by the section of profiles upstream from the dam at Wiggins Mill Reservoir. Slopes of the profiles suggest moderate potentials for sustained base flows from the headwaters of Moccasin Creek to the dam at Wiggins Mill Reservoir. The required minimum release at Buckhorn Reservoir is $1.3 \mathrm{ft}^{3} / \mathrm{s}$; the 7Q10 discharge at the continuous-record gaging station (site 386) downstream from the dam is $0.3 \mathrm{ft}^{3} / \mathrm{s}$ and is based on the full period of record (196595) at the gaging station (table 6). An analysis of the record since the completion of the reservoir in 1976 indicated no difference between the 7Q10 discharge for full period of record at the station and the postregulation period (1977-95). Post-regulation streamflow records at the gaging station below the dam show a number of daily mean discharges less than the required flow release. However, most of these discharges occurred during a drought in 1980-82 that affected streams across the State (Zembrzuski and others, 1991). Minimum-flow releases during extended droughts have been difficult to maintain (James Mead, Division of Water Resources, oral commun., 1998), a reflection of the 7Q10 discharge being significantly less than the required minimum release. No minimumflow releases are required at Wiggins Mill Reservoir although the City of Wilson maintains an open gate at the lower reservoir, which results in a minimum of $1.0 \mathrm{ft}^{3} / \mathrm{s}$ being released downstream (James Mead, Division of Water Resources, written commun., 1998).

The second reach is defined by Contentnea Creek between the dam at Wiggins Mill Reservoir and partial-record measuring site 413 just upstream from Toisnot Swamp near Stantonsburg (fig. 15B). Lowflow discharges at this reach are primarily affected by regulation of flows from Wiggins Mill Reservoir as well as the water-supply withdrawals and corresponding return point-source discharges by the City of Wilson. Withdrawals are made from the reservoir and the point-source discharges occur within 3 mi downstream from the dam (fig. 15B).

Consequently, low-flow profiles between the two diversions do not reflect actual conditions, which include a sudden decrease at the withdrawal location and a corresponding sudden increase at the pointsource discharge. As indicated in table 2, the average return discharge for 1996 by the City of Wilson was $10.3 \mathrm{Mgal} / \mathrm{d}$, compared to the average withdrawal from Contentnea Creek of $5.5 \mathrm{Mgal} / \mathrm{d}$ (plus $2.4 \mathrm{Mgal} / \mathrm{d}$ from Toisnot Lake) for the same period. The higher return discharge reflects the city's treatment of additional wastewater from other smaller municipalities in Wilson County. The increase in net flow between the two diversions is indicated on the profiles by the increase in the low flows in Contentnea Creek immediately below the reservoir (fig. 15B). Downstream from the pointsource discharge, overall slopes shown in the profiles are similar to the first reach. Low-flow discharges at site 393 immediately below the dam are not included on the profiles in this reach because low-flow characteristics are based on flow conditions and withdrawal rates during the 1930-53 period (table 6). Withdrawal rates from the reservoir have increased since that period and no records of discharge are available for determining current low-flow characteristics.

The third reach is Contentnea Creek from its confluence with Toisnot Swamp to the mouth. Lowflow profiles indicate a significant increase in potential for sustained base flows (fig. 15B). Soil hydrologic groups in this area are characterized by a mix of well- 


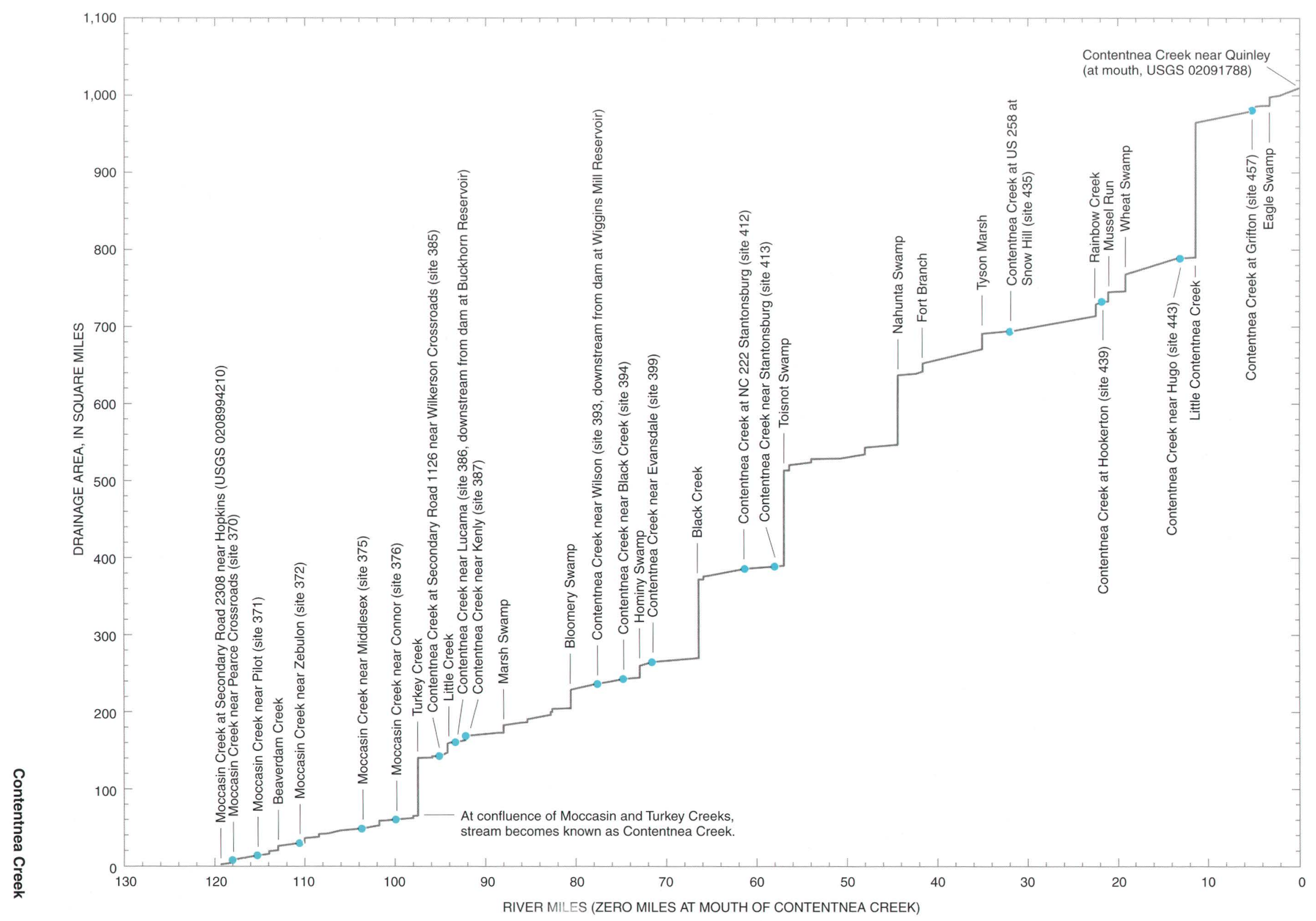

$\stackrel{\text { O }}{ }$ Figure 15A. Relation of river miles to drainage area for Contentnea Creek. 


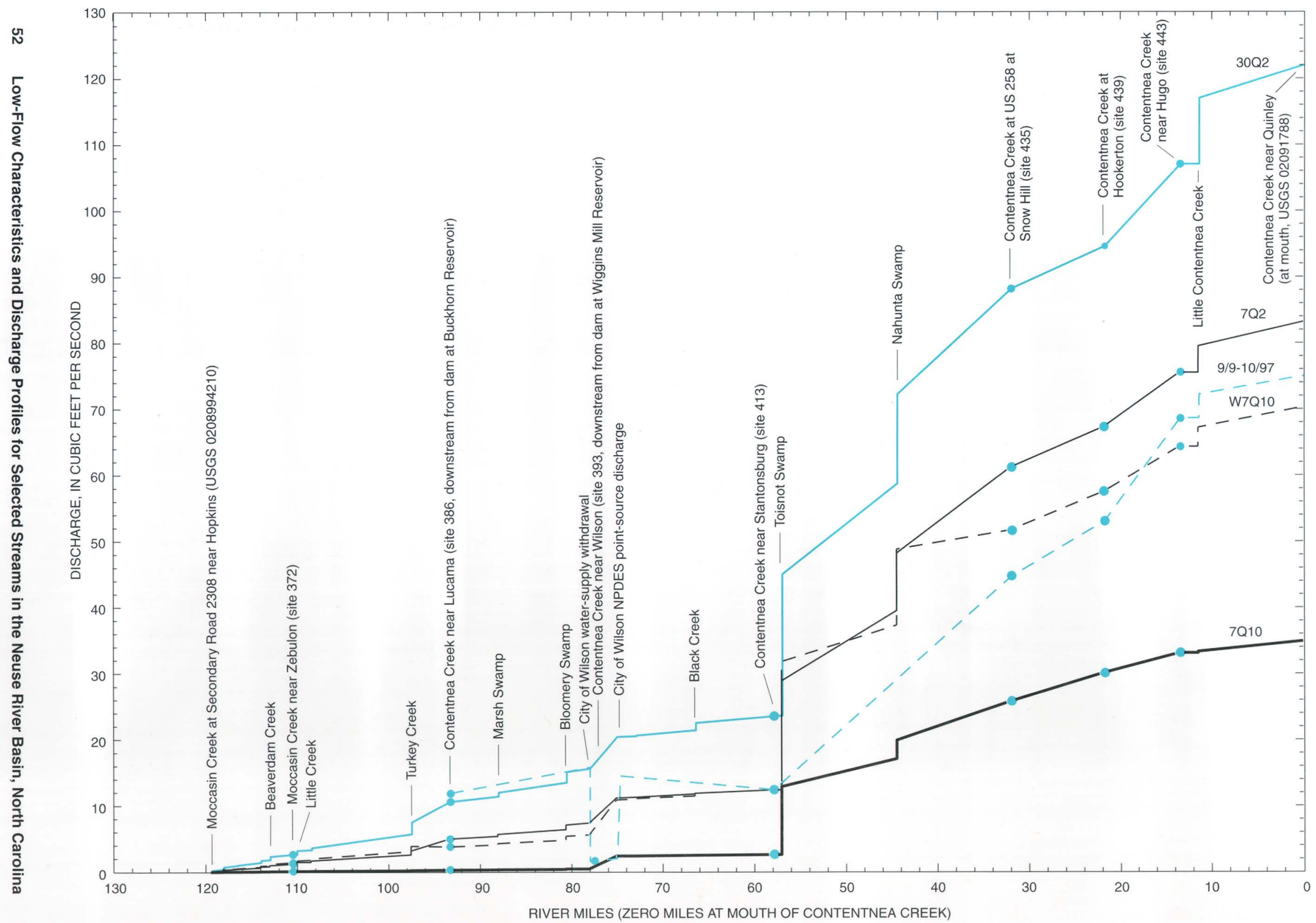

Figure 15B. Relation of river miles to low-flow discharges for Contentnea Creek. 
and moderately drained soils with some poorly drained soils adjacent to the stream channels. The high potential for sustained base flows in the Toisnot Swamp and Nahunta Swamp tributaries contributes to the low flows depicted in this third reach of the Contentnea Creek. Just upstream from the mouth, the low-flow profiles indicate a decrease in potential for sustained base flows, resulting from the relatively lower unit low flows in the flow contributions from Little Contentnea Creek.

In addition to the point-source discharge by the City of Wilson, eight other NPDES point-source discharges in the Contentnea Creek Basin have varying magnitudes of permitted flows and have correspondingly varying effects on the low flows in Contentnea Creek. Five of the eight discharges have permitted flows less than $1.5 \mathrm{ft}^{3} / \mathrm{s}$ each. As suggested by the profiles, the point-source discharge by the Town of Zebulon (permitted flow $1.85 \mathrm{Mgal} / \mathrm{d}$ or nearly $2.9 \mathrm{ft}^{3} / \mathrm{s}$ into Little Creek, tributary of Moccasin Creek) does not appear to significantly affect the low flows in Contentnea Creek. However, the flows of Little Creek, which has a drainage area of $6.2 \mathrm{mi}^{2}$ at its mouth, are likely dominated by this point-source discharge. Conversely, point-source discharges by the Town of Farmville (permitted flow $3.5 \mathrm{Mgal} / \mathrm{d}$ or about $5.4 \mathrm{ft}^{3} / \mathrm{s}$ into Little Contentnea Creek) and by Contentnea Sewerage District (permitted flow $2.85 \mathrm{Mgal} / \mathrm{d}$ or $4.4 \mathrm{ft}^{3} / \mathrm{s}$ into Contentnea Creek) apparently do not comprise a significant portion of the 7Q10 discharge of $33.1 \mathrm{ft}^{3} / \mathrm{s}$ at the partial-record measuring site near Hugo (site 443, table 7).

Discharge measurements at selected locations along Contentnea Creek are profiled to indicate flow conditions along the stream during September 9-10, 1997 (fig. 15B). Included in this profile are the average withdrawal and point-source discharges by the City of Wilson during the same 2-day period. Overall, slopes in the profile of actual measurements roughly parallel the low-flow profiles, particularly between sites 386 and 393 and between sites 413 and 443. These measurements provide a confirmation of the computed low-flow profiles shown for Contentnea Creek. A decrease in discharge is indicated for the reach between the City of Wilson's point-source discharge and partialrecord measuring site 413 near Stantonsburg. Possible explanations for a decrease in flows include irrigation pumping or other normally infrequent withdrawal(s) which may have occurred during the 2-day period.

\section{Neuse River}

Of the three river basins-Tar-Pamlico, Neuse, and Cape Fear River Basins (fig. 1) - that are completely within North Carolina, the Neuse River Basin is the smallest at nearly $5,600 \mathrm{mi}^{2}$, compared to the Tar-Pamlico River Basin at approximately $7,500 \mathrm{mi}^{2}$ and the Cape Fear River Basin at approximately $9,700 \mathrm{mi}^{2}$ (fig. 1; Seaber and others, 1987). The drainage-area profile shows the basin size increases from the headwaters of the West Fork Eno River in Orange County to the mouth of the Neuse River near Maw Point in Pamlico County (fig. 16A). From its headwaters to the mouth, the Neuse River is nearly $310 \mathrm{mi}$ in length. Along its length, the river can be subdivided into three reaches. The first reach is about $46 \mathrm{mi}$ long and consists of the Eno River in Orange and Durham Counties with Little River and Flat River as its two largest tributaries. Where the Eno and Flat Rivers merge to form the Neuse River, the drainage area is $435 \mathrm{mi}^{2}$. In the second reach, $32 \mathrm{mi}$ of the Neuse River is inundated as part of Falls Lake (drainage area $771 \mathrm{mi}^{2}$ at dam), the largest impoundment in the basin. The third reach, $232 \mathrm{mi}$ in length, is the Neuse River between the dam and its mouth near Maw Point. The largest tributary to the Neuse River is Contentnea Creek, which drains $1,010 \mathrm{mi}^{2}$ or 18 percent of the basin. Other large tributaries include Crabtree Creek (146 $\left.\mathrm{mi}^{2}\right)$, Swift Creek $\left(289 \mathrm{mi}^{2}\right)$ in Wake and Johnston Counties, Little River $\left(317 \mathrm{mi}^{2}\right)$, Swift Creek $\left(334 \mathrm{mi}^{2}\right)$ in Pitt and Craven Counties, and the Trent River $\left(519 \mathrm{mi}^{2}\right)$.

Low-flow discharge profiles were developed for the reach of the Neuse River between Falls Lake dam (site 135, drainage area $771 \mathrm{mi}^{2}$ ) and site 460 at Fort Barnwell (drainage area 3,900 $\mathrm{mi}^{2}$ ) (fig. 16B). Lowflow discharges used in the profiles for the long-term continuous-record gaging stations (sites 135, 248, 344, and 361 ; table 6 ) on the Neuse River are based on postregulation flows since the construction of Falls Lake. Low-flow discharges used in the profiles for the partialrecord measuring site at Fort Barnwell (site 460, table 7; operated as a continuous-record gaging station since October 1996) are based on the records of miscellaneous measurements during the 1970-96 water years. Downstream from Fort Barnwell, flows in the river are subject to tidal effects, a factor not readily quantified in low-flow characteristics using available streamflow data and techniques of analysis. 


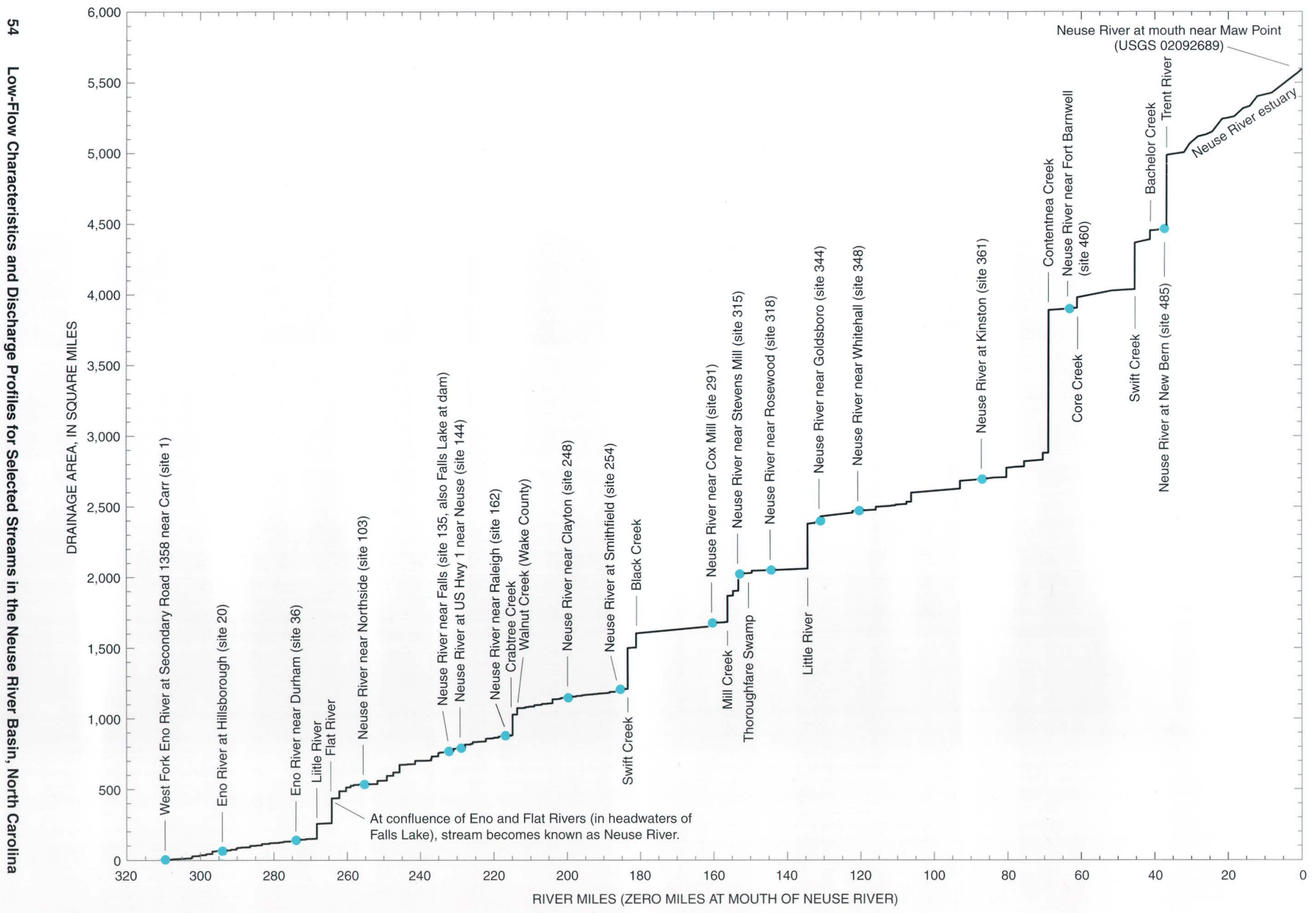

Figure 16A. Relation of river miles to drainage area for the Neuse River. 


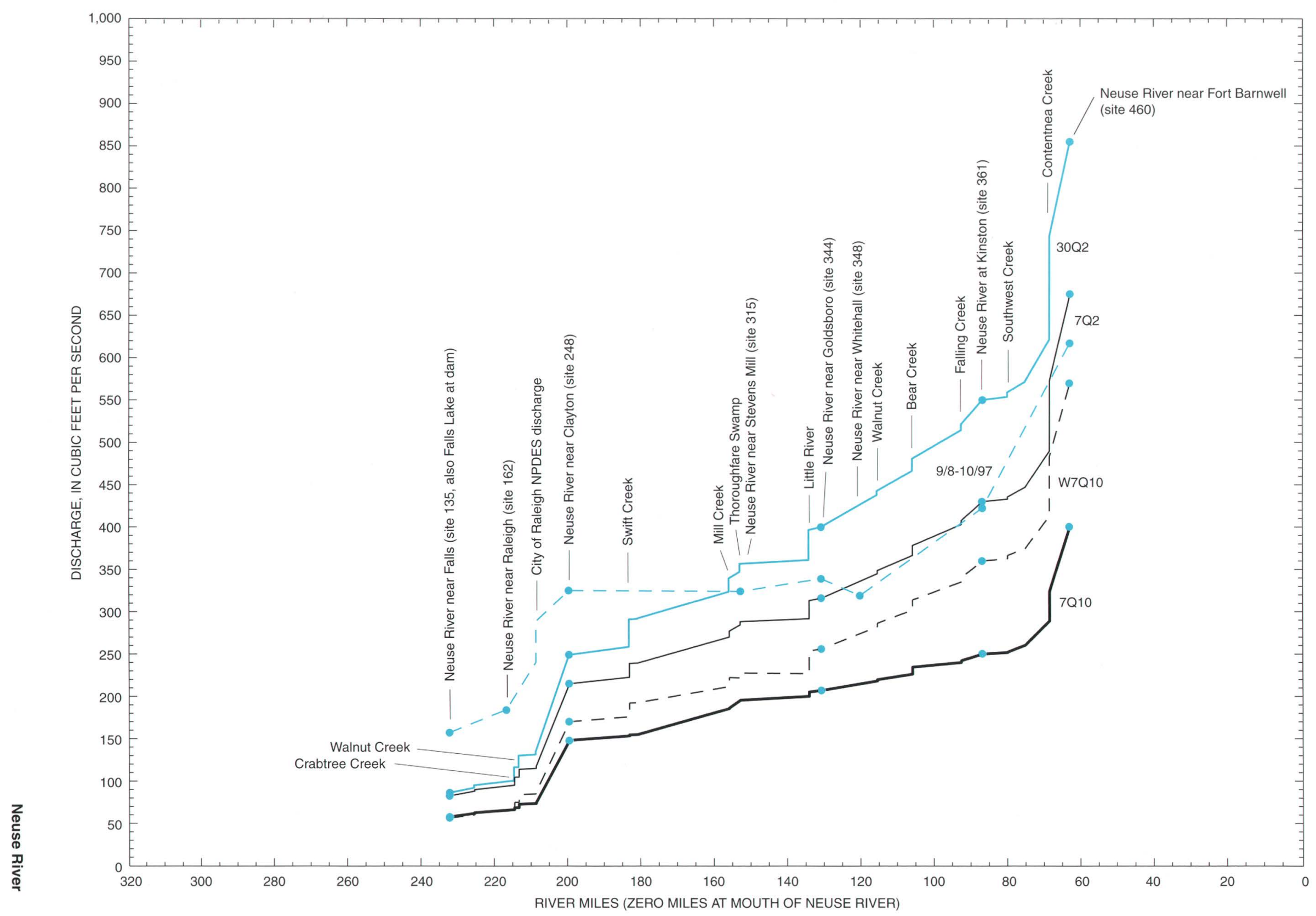

Figure 16B. Relation of river miles to low-flow discharges for the Neuse River. 
The low-flow profiles indicate moderate and steady increases in discharge from Falls Lake dam to Fort Barnwell (fig. 16B). Two sections of the profiles indicate significant and rather sudden increases in lowflow discharges. The first section, between Walnut Creek (Wake County) and the gaging station near Clayton (site 248), includes an NPDES point-source discharge having a permitted flow of $60 \mathrm{Mgal} / \mathrm{d}$ (about $93 \mathrm{ft}^{3} / \mathrm{s}$, table 2). Additionally, tributaries draining to this section of the Neuse River also have relatively high potentials for sustained base flows, attributed to the moderately drained soils weathered from granitic rocks underlying much of Wake County (fig. 6).

The second reach of the Neuse River, for which low-flow profiles indicate significant increases in discharge, occurs between Kinston in Lenoir County and Fort Barnwell in Craven County (fig. 16B) and is about $24 \mathrm{mi}$ in length. Increases in low-flow characteristics between sites 361 and 460 range from 55 to 60 percent (tables 6 and 7). The drainage area increases from 2,692 $\mathrm{mi}^{2}$ (site 361) to about 3,900 $\mathrm{mi}^{2}$ (site 460); most of the increase is associated with Contentnea Creek, which merges with the Neuse River upstream from Fort Barnwell. However, unit low flows at the mouth of Contentnea Creek are much lower relative to the unit low flows at sites 361 and 460 on the Neuse River. For example, the increase in 7Q10 discharge between Kinston and Fort Barnwell is $150 \mathrm{ft}^{3} / \mathrm{s}$, yet only $35 \mathrm{ft}^{3} / \mathrm{s}$ is attributed to Contentnea Creek (fig. 16B). Tributary contributions and the permitted flows from NPDES point-source discharges do not completely account for the increase in 7Q10 discharge between Kinston and Fort Barnwell, indicating the presence of another source of discharge to the Neuse River in this reach.

Winner and Coble (1996) mapped the hydrogeologic framework of aquifers underlying the Coastal Plain of North Carolina. In addition to the surficial aquifer, nine confined aquifers were identified, and their geologic and hydrologic properties were discussed. Results of the mapping indicate direct contact between the Neuse River channel and the Castle Hayne aquifer between Kinston and Fort Barnwell (Winner and Coble, 1996, pl. 18). The Castle Hayne aquifer is described as the most productive of the 10 aquifers in terms of yield, a factor attributed to the extensive occurrence of porous limestone in the aquifer. Throughout much of its thickness, this aquifer has an average composition of 80 to 90 percent permeable material (Winner and Coble, 1996). Thus the sudden increase in discharge shown in low-flow profiles for the Neuse River between Kinston and Fort Barnwell is likely the result of ground-water discharge from the Castle Hayne aquifer directly into the Neuse River. Maps of the Castle Hayne aquifer in Winner and Coble (1996, pl. 18) show that direct contact between the Neuse River and the aquifer extends downstream to a point near the confluence with Swift Creek. Direct contact with this aquifer also is noted in the part of the study area drained by Core Creek, a tributary to the Neuse River just downstream from Fort Barnwell (Winner and Coble, 1996). Therefore, it is likely that the Castle Hayne aquifer contributes flow to the Neuse River for another 10-12 miles downstream from Fort Barnwell.

A profile of actual discharge measurements at selected locations on the Neuse River is included in the low-flow profiles for the Neuse River (fig. 16B). The measurements used to develop this profile were obtained during September 8-10, 1997, a period of base-flow conditions throughout much of the Neuse River Basin. The profile indicates that flow conditions in the Neuse River were above 30Q2-discharge conditions between Falls Lake dam and Mill Creek, the last major tributary in Johnston County. In Wayne County, flows transition to 7Q2-discharge conditions in the remainder of the Neuse River to Fort Barnwell. The slope of the measured profile between Kinston and Fort 
Barnwell increases significantly and provides a confirmation of the slopes for the low-flow profiles. Between Clayton and Goldsboro, the measured profile suggests a loss in flows between several points. Changes in flows resulting from water withdrawals and point-source discharges are not detailed in the profile. Further, the presence of discharges greater than 30Q2flow conditions in the upper reaches of the profile compared to 7Q2 conditions in the lower reaches suggests a change in flows as a result of thunderstorms over parts of the upper Neuse River Basin during the measurement period.

Twenty-four NPDES point-source discharges exist for the Neuse River downstream from Falls Lake dam. Additionally, four water-supply withdrawals (Johnston County, Town of Smithfield, City of Goldsboro, Weyerhaeuser Company) also occur in the Neuse River downstream from Falls Lake. The largest point-source discharge has a permitted flow of $60 \mathrm{Mgal} / \mathrm{d}$ (about $93 \mathrm{ft}^{3} / \mathrm{s}$, table 2) compared to the $7 \mathrm{Q} 10$ discharge $\left(75 \mathrm{ft}^{3} / \mathrm{s}\right)$ estimated from the profiles for the point just downstream from Poplar Creek in Wake County (fig. 16B). Other permitted point-source discharges for Johnston County, City of Goldsboro, City of Kinston (both plants), and the DuPont industrial facility near Kinston have permitted flows of 4.5, 10.1, 11.25 , and $3.6 \mathrm{Mgal} / \mathrm{d}$, respectively (table 2 ). The permitted flows are equivalent to about 7.0, 15.6, 17.4, and $5.6 \mathrm{ft}^{3} / \mathrm{s}$, respectively, compared to the postregulation 7Q10 discharges at the gaging stations at Goldsboro and Kinston (sites 344, 361) of 207 and $250 \mathrm{ft}^{3} / \mathrm{s}$, respectively (table 6). Aside from plant capacities, no limits generally exist for water-supply withdrawals. The largest average withdrawal downstream from Falls Lake dam in 1996 was $20 \mathrm{Mgal} / \mathrm{d}$ (nearly $31 \mathrm{ft}^{3} / \mathrm{s}$, table 2 ). The three watersupply withdrawals by Johnston County, Town of
Smithfield, and City of Goldsboro averaged 3.5, 4.0, and $6.3 \mathrm{Mgal} / \mathrm{d}\left(5.4,6.2\right.$, and $\left.9.7 \mathrm{ft}^{3} / \mathrm{s}\right)$, respectively, during 1996 (table 2).

As part of its assessment and management of water-quality issues, the DWQ uses a flow model for low flows in the Neuse River between Falls Lake dam and New Bern. The model is based on an assumption of steady low-flow conditions for winter (November through March) and summer (April through October) periods. The model allocates the flow in two subreaches of the Neuse River-from Falls Lake dam to the gaging station near Clayton (site 248) and from the Clayton gage to New Bern. In addition to seasonal minimum flow releases $\left(100 \mathrm{ft}^{3} / \mathrm{s}\right.$ in the summer and $65 \mathrm{ft}^{3} / \mathrm{s}$ in the winter) required at Falls Lake dam, flows in the first reach also are allocated so as to maintain target flows at the Clayton gage $\left(254 \mathrm{ft}^{3} / \mathrm{s}\right.$ in the summer and $184 \mathrm{ft}^{3} / \mathrm{s}$ in the winter). The model also incorporates maximum changes caused by flow diversions; the maximum changes reflect permitted flows assigned to NPDES point-source discharges and withdrawals defined by current or future plant capacities for various municipalities.

The USGS discharge profiles are based on analyses of observed discharges at numerous gaging stations and, thus, are hydrologic assessments of the flows at these stations. Effects of daily flow diversions, particularly at long-term gaging stations, are included in the record of discharge collected at the sites.

However, the daily flow diversions usually do not cyal the maximum changes seen in the DWQ models. The DWQ's incorporation of maximum changes caused by flow diversions is consistent with their role in managing and assessing water-quality issues by planning for flow allocations under "worst-case" lowflow conditions, as mandated by State regulations. 


\section{Swift Creek (Pitt and Craven Counties)}

Swift Creek drains about $330 \mathrm{mi}^{2}$ in parts of Pitt and Craven Counties and merges with the Neuse River just north-northwest of New Bern (pl. 1). The drainagearea profile indicates increases in the basin size between site 463 (approximately river mile 43) and the mouth (fig. 17A). Swift Creek is about $45 \mathrm{mi}$ in total length. The largest tributaries to Swift Creek are Clayroot Swamp and Little Swift Creek; other significant tributaries include Fork Swamp, Palmetto Swamp, and Mauls Swamp. As suggested by tributary names, much of the study area drained by Swift Creek is swampy terrain.

The low-flow profiles for Swift Creek depict the flows between Winterville (site 463) and Vanceboro (site 472) (fig. 17B). No estimates of low-flow discharges for the site (477) at Streets Ferry are included in the compilations (tables 6,7 ) or shown on the profiles because less than 2 years of data exist for this site and because the effects of tides on low-flow discharges currently cannot be quantified in analyses. Downstream from the partial-record measuring site (468) near Coxville, profile slopes indicate increases in low-flow discharges. The slopes of the low-flow profiles between Winterville (site 463) and Coxville (site 468) are confirmed by a measured profile on September 9, 1997, for selected locations in this reach of Swift Creek. The measured profile indicates that flows were between 30Q2- and 7Q2-discharge conditions on this date. No measurement was obtained at site 472 near Vanceboro because measuring conditions were unsuitable.

As with the lower reach of Neuse River between Kinston and Fort Barnwell, low-flow profiles for Swift Creek indicate the occurrence of ground-water discharge from underlying aquifers (fig. 17B). Estimates of low flows at gaging stations on Creeping Swamp (tributary to Clayroot Swamp) and Palmetto Swamp (sites 470, 471, and 475) are zero (table 6). Because of the extensive occurrence of poorly drained soils throughout the Swift Creek Basin, other tributary contributions to Swift Creek during low-flow conditions are likely minimal, if not zero.

Correspondingly, no flow contributions from tributaries are shown in these profiles. However, increases in unit low flows between Coxville (site 468) and Vanceboro (site 472) indicate the addition of flow from a source other than tributary contributions or NPDES point-source discharges. This source is most likely ground-water discharge from the surficial aquifer, which is underlain by the Castle Hayne aquifer. Despite the presence of a confining unit between the surficial and Castle Hayne aquifers, Winner and Coble (1996) noted that the potential for significant upward flow of ground water into stream channels still exists.

There are no records of NPDES point-source discharges into Swift Creek. One point-source discharge having a permitted flow of about $0.4 \mathrm{ft}^{3} / \mathrm{s}$ (0.25 Mgal/d) occurs in Mauls Swamp just upstream from its confluence with Swift Creek. 


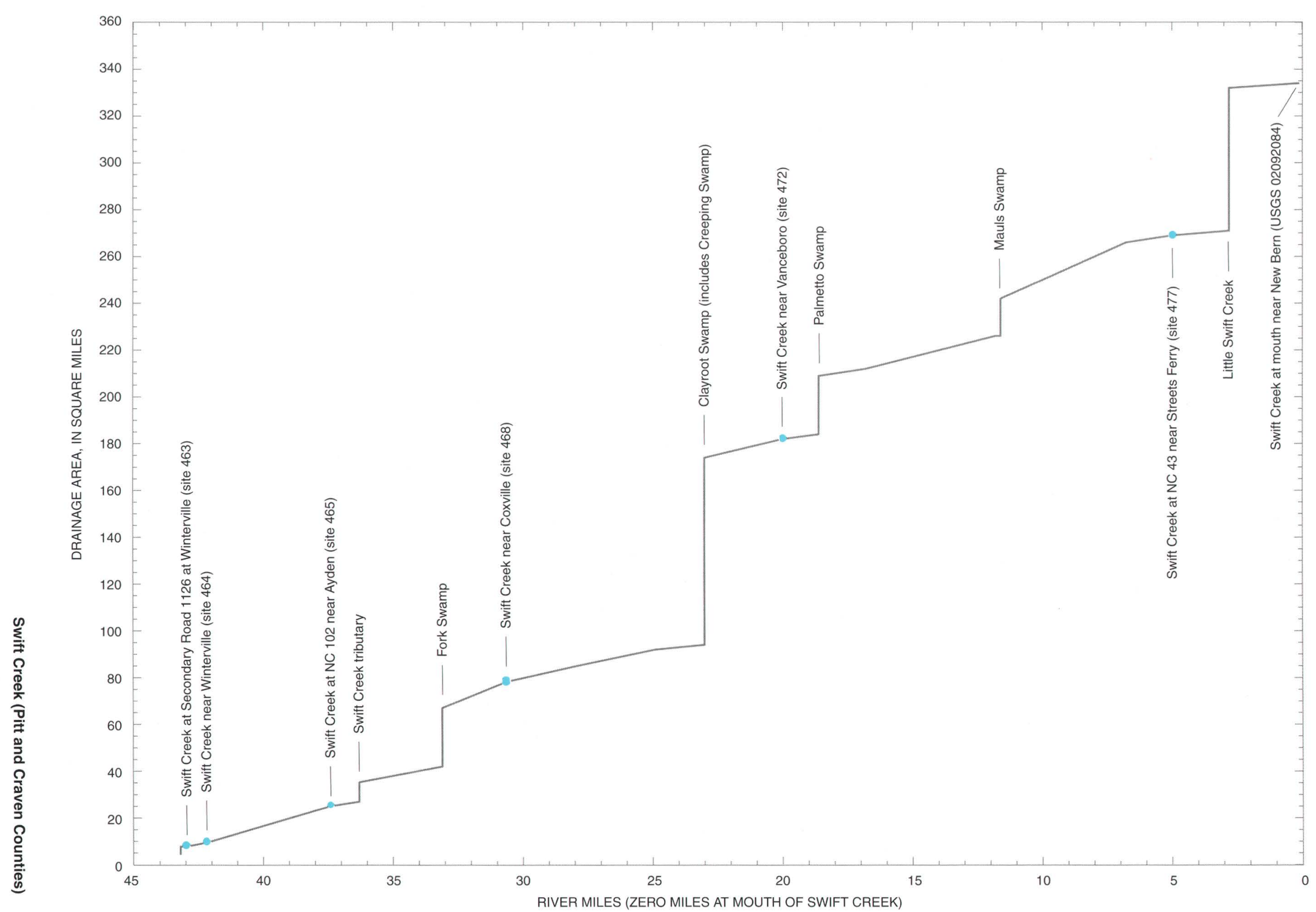

Figure 17A. Relation of river miles to drainage area for Swift Creek (Pitt and Craven Counties). 


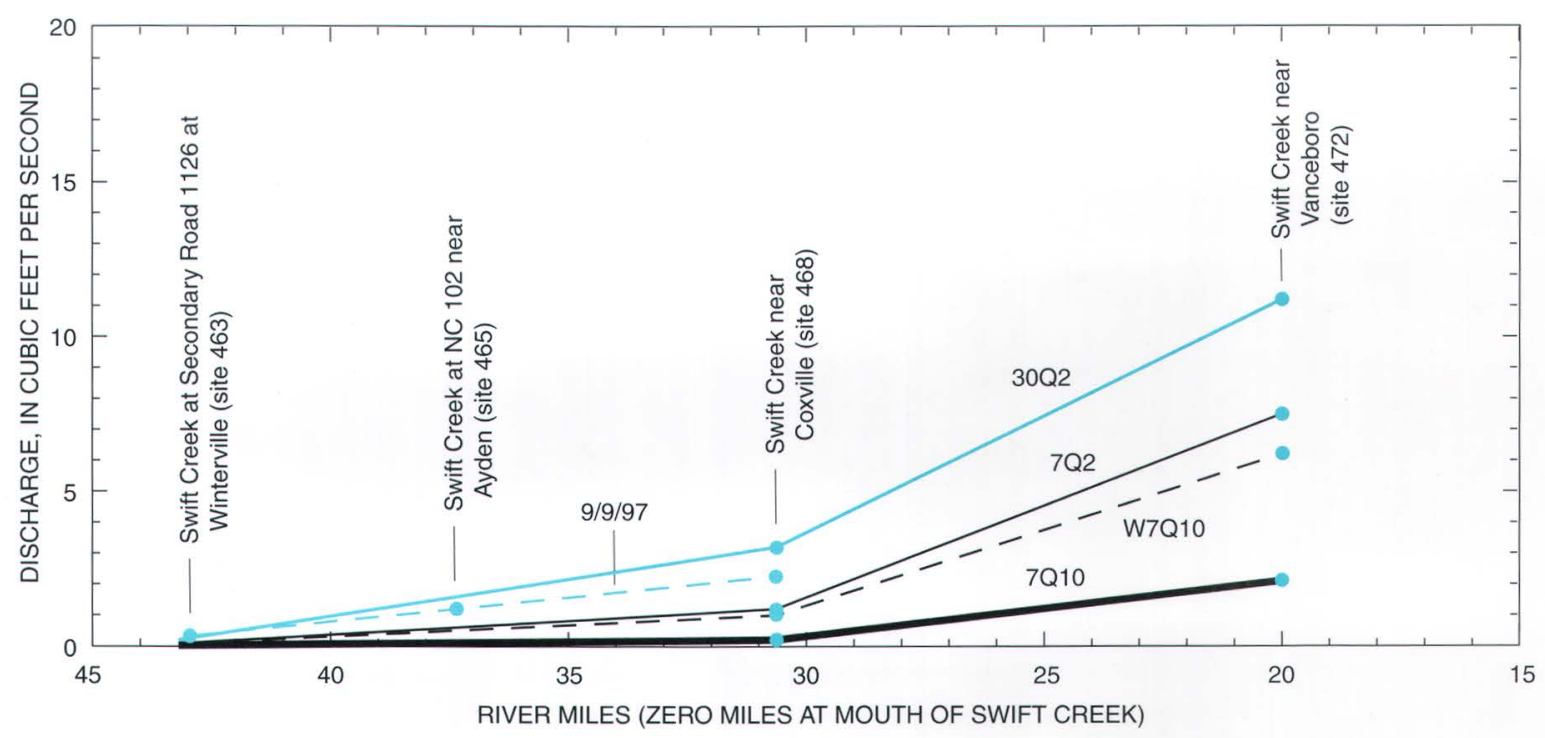

Figure 17B. Relation of river miles to low-flow discharges for Swift Creek (Pitt and Craven Counties).

\section{Trent River}

At the mouth, the Trent River Basin is about 520 $\mathrm{mi}^{2}$ and drains parts of Lenoir, Jones, and Craven Counties (pl. 1). The river drains to the upper reaches of the Neuse River estuary at New Bern. The Trent River is nearly $87 \mathrm{mi}$ in length; drainage areas for the Trent River were profiled from site 486 near Deep Run to the mouth (fig. 18A). Major tributaries to the Trent River include Tuckahoe Creek, Beaver Creek, and Brice Creek.

Low-flow profiles shown for the Trent River are limited to the reach of the river between Deep Run (site 486) and Trenton (site 494) (fig. 18B). Downstream from Trenton, flows gradually become subject to the effects of tides. Similar to that noted for the site on Swift Creek at Streets Ferry (site 477, see preceding section), no estimates of low-flow discharges for the site (500) on Trent River at Pollocksville are included in the compilations (tables 6,7 ) or shown on the profiles. This site also has less than 2 years of data, and as previously discussed, the effects of tides on low-flow discharges cannot be readily quantified using available techniques of low-flow analyses. For the upper reach shown in the profiles, tributaries apparently do not contribute flows to the Trent River during extended drought periods (fig. 18B). This observation is supported by comparison of the low-flow discharges listed in tables 6 and 7 for the sites near Deep Run (486) and Trenton (494); unit low flows decrease significantly between the two sites suggesting that, while the drainage area increases, flow contributions from tributaries are minimal at best. Further support for this observation also is provided by table 7 where the occurrence of zero 7Q10 discharges is noted for a number of sites $(490,492,496)$ tributary to the Trent River.

Although low-flow profiles for the reach downstream from Trenton are currently not available, the Castle Hayne aquifer likely contributes groundwater discharge to the Trent River and some of its tributaries. Winner and Coble (1996, pl. 18) indicated that the Castle Hayne aquifer, the most productive aquifer identified in North Carolina, discharges directly into the Trent River in the form of upward leakage. Between the river's confluence with Tuckahoe Creek and its entry into Craven County, the stream channel cuts into the Castle Hayne aquifer. The effects of ground-water discharge from the Castle Hayne aquifer also appear to affect the low-flow characteristics of some tributaries to the Trent River. The 7Q10 discharges for Beaver Creek (site 497) and Musselshell Creek (site 498) have magnitudes which, relative to other nearby tributaries, may include discharge from the Castle Hayne aquifer (table 7).

There are three permitted point-source discharges having a total permitted flow of about $0.475 \mathrm{Mgal} / \mathrm{d}\left(0.7 \mathrm{ft}^{3} / \mathrm{s}\right)$. Two of the three discharges, including the largest discharge permitted at about $0.33 \mathrm{Mgal} / \mathrm{d}\left(0.5 \mathrm{ft}^{3} / \mathrm{s}\right.$, table 2$)$, are located in tidally affected reaches downstream from Pollocksville. 
ฝәк!บ ұиәдџ

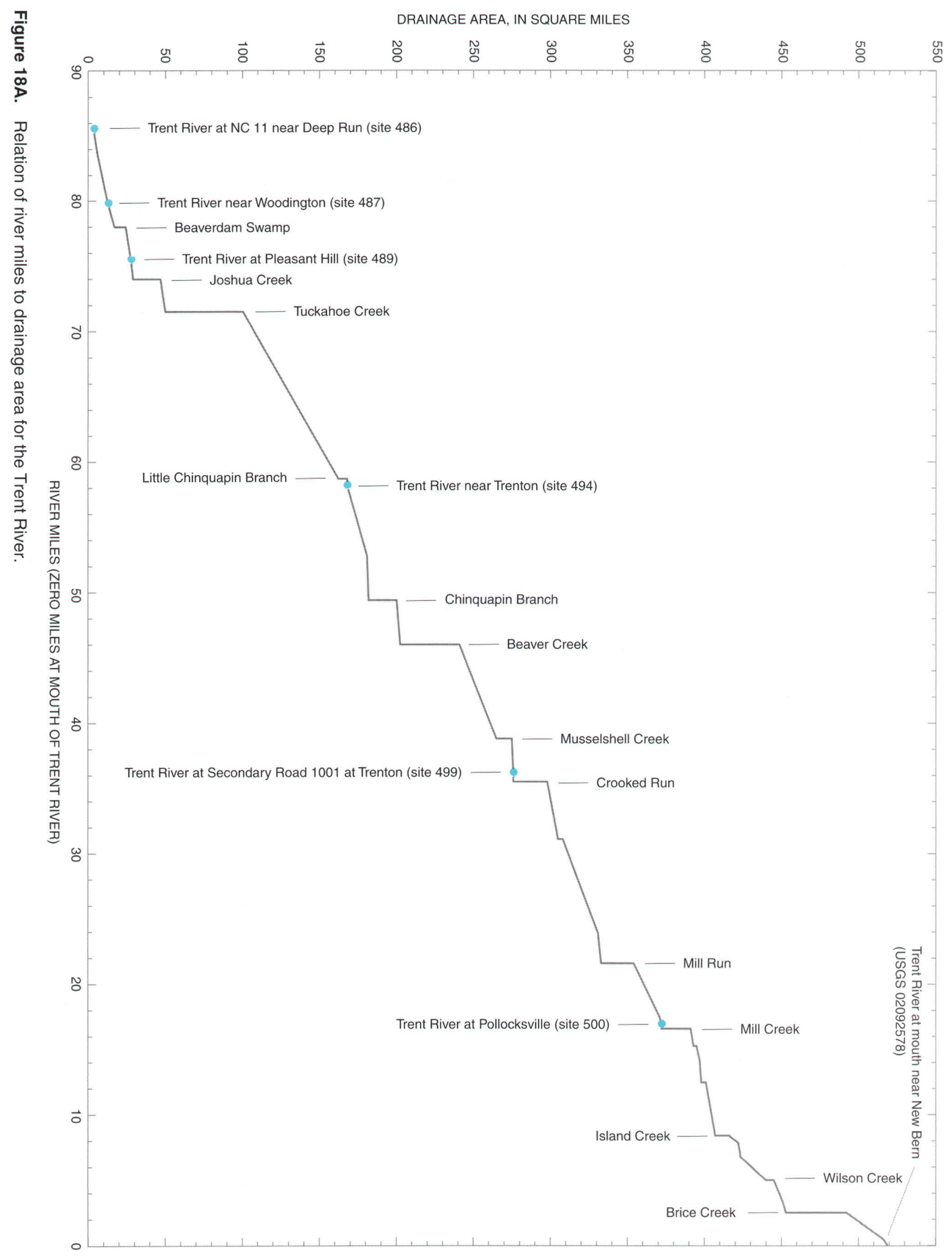




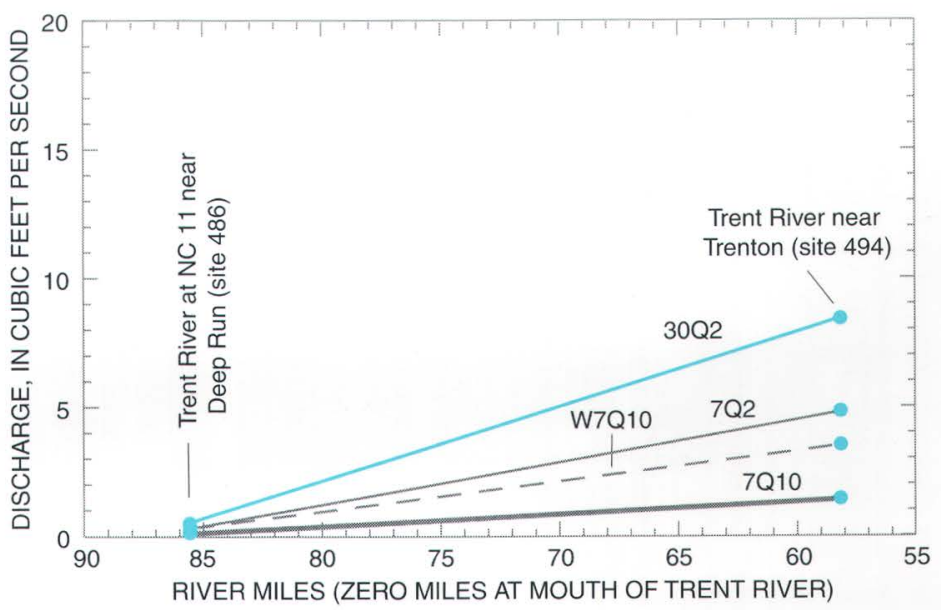

Figure 18B. Relation of river miles to low-flow discharges for the Trent River.

Provided that streamflow monitoring continues at the sites on Swift Creek at Streets Ferry (site 477) and Trent River at Pollocksville (site 500), a better understanding of low-flow characteristics may be possible with additional streamflow data and with the development of techniques for assessing low flows in tidally affected reaches. Additionally, a better understanding may possibly permit future extension of the low-flow profiles in the lower reaches of Swift Creek and the Trent River.

\section{SUMMARY}

This report describes low-flow characteristics for the Neuse River Basin in North Carolina through the 1996 water year and 1995 climatic year. Low-flow characteristics are summarized for a number of existing gaging stations in the study area, and drainage area and low-flow discharge profiles are presented for selected rivers and streams. Estimates of low flows presented in this report were prepared in cooperation with the North Carolina Division of Water Quality (DWQ, formerly known as the Division of Environmental Management) of the Department of Environment and Natural Resources. In 1991, the DWQ began using a basinwide approach in its assessment of water-quality conditions in North Carolina; part of the assessment includes the simultaneous evaluation of National Pollution Discharge Elimination System (NPDES) permits for point-source discharges to streams in the basin. The Neuse River Basin is one of 17 major river basins selected by the DWQ for the purposes of conducting the basinwide assessments.

Located in central eastern North Carolina, the Neuse River drains about $5,600 \mathrm{mi}^{2}$ and is nearly 310 mi between its headwaters (West Fork Eno River) in Orange County and its mouth near Maw Point in Pamlico County. The largest tributary to the Neuse River is Contentnea Creek. The Neuse River Basin is the smallest of the three river basins (Tar-Pamlico, Neuse, and Cape Fear River) that are completely within North Carolina. The upper one-third of the basin is in the Piedmont Province and is characterized by rolling and hilly topography. The lower two-thirds of the basin is in the Coastal Plain and is characterized by a gradual transition from gentle, rolling hills with little relief to nearly level land surfaces.

Selected basin characteristics and their known effects on low-flow characteristics are described in this report. Major flow modifications caused by impoundments and diversions from and into streams in the study area were examined to determine the effects on low-flow characteristics. Nearly 550 impoundments with structural heights exceeding 15 feet were identified in the investigation. The largest impoundment in the basin is Falls Lake, in Wake and Durham Counties, which has a surface area of nearly 12,500 acres. Eight other major impoundments with surface areas exceeding 200 acres exist in the basin. Although the effects of these impoundments on downstream low flows vary, the primary effect is downstream dependence upon the presence of a minimum flow release at the dam. Not all of the major impoundments identified in this report have minimum 
flow releases. Among these impoundments, those constructed since the mid-1980's generally have been assigned minimum releases as a result of the revised procedures for evaluating the effects of dams on downstream flows.

A total of 65 withdrawals exceeding $1 \mathrm{Mgal} / \mathrm{d}$ are registered with the State of North Carolina; most are made by municipalities and major industries for water supply and manufacturing purposes. The State also permits 185 point-source discharges under the NPDES permitting system; 28 are deemed by the State as being major discharges. A number of major withdrawals and point-source discharges can be paired and thus result in negligible effects on low flows. The largest withdrawal and, correspondingly, the largest point-source discharge in the basin is made by the City of Raleigh, which withdrew and discharged an average of 43.0 and $33.9 \mathrm{Mgal} / \mathrm{d}$, respectively, in 1996 . Other significant flow diversions exceeding $5 \mathrm{Mgal} / \mathrm{d}$ were made by the Cities of Durham and Goldsboro. In the Coastal Plain, some facilities that discharge to streams do not make surface-water withdrawals, but rather obtain water supplies from ground water or by transfer from other facilities. Other flow modifications having potentially significant effects on low flows are unknown withdrawals in small to mid-size basins that are not required to register with the State. Often made for irrigation or de-watering (mining) purposes, the cumulative effect of multiple withdrawals, particularly in small to mid-size subbasins that have low potential to sustain base flows, could be to further reduce the availability of flow in nearby streams for assimilating effluent from point-source discharges. Some withdrawals, identified but not documented in this report, include those made at a number of quarry operations or at farming and agricultural-research operations in the basin.

Variability of average rainfall amounts occurring in the Neuse River Basin is partly reflected in the potential to sustain low flows in the study area. Annual rainfall amounts in the lower parts of the basin were about 8 inches higher than in the headwaters. A comparison of two sites-Little River in Durham County and Nahunta Swamp in Greene County-in the basin with identical drainage areas revealed a higher 7Q10 discharge at Nahunta Swamp. Overall, soil hydrologic groups in the subbasins drained by each site were identified as moderately drained. Thus, the higher 7Q10 discharge at Nahunta Swamp likely reflects the higher average annual rainfall at that site.
Available documentation of soils was examined to determine the effects on low flows in the study area. Soil hydrologic groups, when mapped throughout the study area, generally correspond to the potential to sustain base flows. Some soils in parts of the headwaters of the Neuse River Basin, particularly those derived from Triassic basin rocks, are classified as having low infiltration rates and reflect the low potential to sustain base flows for streams in that area. Numerous sites in western Wake County and Durham County have zero or minimal 7Q10 discharges (defined as less than $0.05 \mathrm{ft}^{3} / \mathrm{s}$ ). Many soils in the study area within the lower Coastal Plain also are classified as having low infiltration rates. Similarly, the potential for sustaining base flows at many of the gaging stations in this area is low. Many soils in the central part of the basin are classified as moderately and well drained.

Land use in the basin is mostly rural; slightly over 71 percent is classified as agricultural or forested. Five percent of the basin is urban with Raleigh and Durham in Wake and Durham Counties, respectively, being the largest municipalities in the study area. Wetlands occupy more than 18 percent of the study area, primarily adjacent to streams in the lower parts of the basin in the Coastal Plain. Changes in land use are difficult to quantify because of the methods and resolution of techniques used in compiling information for different land-use data bases. The most notable changes have been the widespread conversion of agricultural and forest covered land to developed land in the Raleigh and Durham municipalities.

Surface-water data were identified and compiled for 508 sites in the study area. Low-flow characteristics (7Q10, 30Q2, W7Q10, and 7Q2) were determined for 163 sites (50 continuous-record and 113 partialrecord). At four gaging stations having continuous records of daily mean discharge on the Neuse River downstream from Falls Lake, a common base period (1984-95 climatic years) was selected for use in determining low-flow characteristics. This period reflects the regulation of flows by Falls Lake since its construction. When unit low flows were plotted on a map of the study area, two general areas of zero or minimal 7Q10 discharges were recognized. A number of sites in the upper part of the basin, as well as many of the sites in lower areas of the Coastal Plain, have zero or minimal 7Q10 discharges. The poorly sustained base flows are reflective of soils having low infiltration rates; little water is stored in the surficial aquifers in these areas which results in little to no water being 
available for release to streams during extended dry periods. Occurrences of zero or minimal 7Q10 discharges in the central part of the basin were noted, though on a more widespread basis. In that area, low flows are more likely affected by a combination of factors (soils, degree of terrain slope, and drainage area), whereas in the upper and lower ends of the basin, the predominant factor in occurrences of zero or minimal 7Q10 discharges is the presence of poorly drained soils.

Drainage area and low-flow discharge profiles were developed for 10 streams and rivers in the study area. Streams profiled in this report include the Neuse River (between Falls Lake and Fort Barnwell) and selected tributaries to the Neuse River. The selected tributaries include Perry Creek, Walnut Creek (Wake County), Poplar Creek, Swift Creek (Wake and Johnston Counties), Little River, Walnut Creek (Wayne County), Contentnea Creek, the Neuse River, Swift Creek (Pitt and Craven Counties), and the Trent River. The low-flow discharge profiles indicate the 7Q10, 30Q2, W7Q10, and 7Q2 discharges. For the Neuse River and selected tributaries, a profile of discharge measurements obtained at multiple points in September 1997 provides a "snapshot" of actual flow conditions during a period of extended dry conditions.

Perry Creek, Poplar Creek, and both Walnut Creeks (Wake County and Wayne County) each drain less than $50 \mathrm{mi}^{2}$. Low-flow characteristics at Perry Creek and Poplar Creek have relatively high potential for sustained base flows as a result of the moderately drained soils weathered from granitic rocks underlying much of Wake County. Similarly, low-flow characteristics in the lower reaches of Walnut Creek in Wake County reflect relatively high potentials for sustained base flows although low flows in its headwaters are not as sustained, most likely a result of its proximity to the Triassic basin, an area that contains poorly drained soils. Low flows in Walnut Creek in Wayne County apparently reflect the presence of moderately and well-drained soils in parts of the subbasin.

Swift Creek (Wake and Johnston Counties) and Little River drain $289 \mathrm{mi}^{2}$ and $317 \mathrm{mi}^{2}$, respectively, of the central part of the Neuse River Basin. Similar to Walnut Creek in Wake County, low-flow discharge profiles for Swift Creek indicate a stream in which the potential for sustained base flows increases between the headwaters and its mouth, a result of transition from poorly drained soils to moderately drained soils.
Discharge profiles for the Little River indicate moderately to highly sustained base flows, particularly in the middle and lower reaches partly as a result of the river's movement through the Fall Line.

Contentnea Creek, the largest tributary to the Neuse River, has a drainage area $1,010 \mathrm{mi}^{2}$ at its mouth. The stream begins as Moccasin Creek and merges with Turkey Creek to become Contentnea Creek. Two impoundments, Buckhorn Reservoir and Wiggins Mill Reservoir, are on Contentnea Creek and affect the low flows on the stream through flow releases from the dams. Overall, low-flow discharge profiles for Contentnea Creek reflect moderate potential for sustained base flow. Infiltration rates for soils in the subbasin and, in particular, along tributary streams in Wilson County are classified as well drained. Some occurrence of poorly drained soils were noted along Contentnea Creek, but the effects of these soils on low flows are apparently superseded by the effects of the well-drained soils. NPDES point-source discharges in the Contentnea Creek subbasin have varying magnitudes of permitted flows and have correspondingly varying effects on the low flows in Contentnea Creek. The most significant effect on base flow occurs on the stream below Wiggins Mill Reservoir where the City of Wilson has a withdrawal and point-source discharge occurring within 3 miles. Higher amounts from the point-source discharge result in an increase in low-flow discharge profiles in the downstream reaches.

Swift Creek (Pitt and Craven Counties) and the Trent River drain $334 \mathrm{mi}^{2}$ and $519 \mathrm{mi}^{2}$, respectively, and are in the lower parts of the study area in the lower Coastal Plain. Most soils in both subbasins are classified as being poorly drained, and numerous zeroand minimal 7Q10 discharges were noted, particularly for tributary streams. Low-flow profiles were not developed for the lower reaches of Swift Creek and the Trent River due to the presence of tidal influences which cannot be readily quantified using available techniques of low-flow analyses. However, groundwater discharge from the underlying Castle Hayne aquifer appears to be a component of the overall flows in these streams despite the absence of contributing flows from tributaries. The Castle Hayne aquifer is composed of permeable material derived from the extensive presence of porous limestone in the aquifer.

The drainage-area profile for the Neuse River shows increases in basin size between the headwaters and its mouth. The low-flow profiles indicate changes 
in low-flow characteristics between Falls Lake and Fort Barnwell. Overall, low-flow profiles show moderate and steady increases in discharge for much of this reach. The most prominent feature noted in the lowflow profiles is the significant and sudden increase in low flows between Kinston (site 361) and Fort Barnwell (site 460). Despite a nearly 45-percent increase in drainage area, tributary contributions do not account for the increase in low flows in this reach. As with nearby Swift Creek and the Trent River, increases in this reach are primarily a result of ground-water discharge from the underlying Castle Hayne aquifer. Effects of regulation by Falls Lake dam can be observed in changes between pre- and post-regulation streamflows as far downstream as Kinston. Twentyfour NPDES point-source discharges were noted for the Neuse River downstream from Falls Lake; additionally, four water-supply withdrawals also occur in that reach.

\section{SELECTED REFERENCES}

Barnes, C.R., 1986, Method for estimating low-flow statistics for ungaged streams in the lower Hudson River Basin, New York: U.S. Geological Survey Water-Resources Investigations Report 85-4070, $22 \mathrm{p}$.

Bingham, R.H., 1985, Low flows and flow duration of Tennessee streams through 1981: U.S. Geological Survey Water-Resources Investigations Report 84-4347, $325 \mathrm{p}$.

Bondelid, T.R., Hanson, S.A., and Taylor, P.L., 1990, Technical description of the reach file: U.S. Environmental Protection Agency RF1/2/3 Draft, $17 \mathrm{p}$.

Brown, C.E., 1988, Determination of rock properties by borehole-geophysical and physical-testing techniques and ground-water quality and movement in the Durham Triassic basin, North Carolina: U.S. Geological Survey Professional Paper 1432, 29 p.

Carter, R.F., Hopkins, E.H., and Perlman, H.A., 1988, Low-flow profiles of the Upper Savannah and Ogeechee Rivers and tributaries in Georgia: U.S. Geological Survey Water-Resources Investigations Report 88-4047, 169 p.

Daniel, C.C., III, 1989, Statistical analysis relating well yield to construction practices and siting of wells in the Piedmont and Blue Ridge Provinces of North Carolina: U.S. Geological Survey Water-Supply Paper 2341-A, $27 \mathrm{p}$.
Daniel, C.C., III, and Payne, R.A., 1990, Hydrogeologic unit map of the Piedmont and Blue Ridge Provinces of North Carolina: U.S. Geological Survey WaterResources Investigations Report 90-4035, 1 sheet, scale 1:500,000.

Evett, J.B., 1994, Effects of urbanization and land-use changes on low stream flow: Raleigh, The University of North Carolina Water Resources Research Institute, Report No. 284, 146 p.

Fenneman, N.M., 1938, Physiography of Eastern United States: New York, McGraw-Hill, 714 p.

Fransen, T., 1991, Hydrology for 1990, in Rulifson, R.A., and Manooch, C.S., III, eds., Roanoke River water flow committee report for 1990: National Ocean and Atmospheric Administration Technical Memorandum NMFS-SEFC-291, p. 139-162.

Giese, G.L., Eimers, J.L., and Coble, R.W., 1997, Simulation of ground-water flow in the Coastal Plain aquifer system of North Carolina: U.S. Geological Survey Professional Paper 1404-M, 142 p.

Giese, G.L., and Mason, R.R., Jr., 1993, Low-flow characteristics of streams in North Carolina: U.S. Geological Survey Water-Supply Paper 2403, $29 \mathrm{p}$.

Giese, G.L., Wilder, H.B., and Parker G.G., Jr., 1985, Hydrology of major estuaries and sounds of North Carolina: U.S. Geological Survey Water-Supply Paper 2221, 108 p.

Goddard, G.C., Jr., 1963, Water-supply characteristics of North Carolina streams: U.S. Geological Survey WaterSupply Paper 1761, 223 p.

Hale, T.W., Hopkins, E.H., and Carter, R.F., 1989, Effects of the 1988 drought on streamflow in Alabama, Georgia, North Carolina, South Carolina, Tennessee, and Virginia: U.S. Geological Survey Water-Resources Investigations Report 89-4212, $102 \mathrm{p}$.

Hayes, D.C., 1991, Low-flow characteristics of streams in Virginia: U.S. Geological Survey Water-Supply Paper 2374, $69 \mathrm{p}$.

Khorram, S., Chesire, H., Siderelis, K., and Nagy, Z., 1991, Mapping and GIS implementation of land use and land cover categories for the Albemarle-Pamlico drainage basin: Raleigh, N.C., Computer Graphics Center, North Carolina State University and the Center for Geographic Information and Analysis, North Carolina Department of Environment, Health, and Natural Resources, $53 \mathrm{p}$.

Kopec, R.J., and Clay, J.W., 1975, Climate and air quality, in Clay, J.W., Orr, D.M., Jr., and Stuart, A.W., eds., North Carolina atlas-Portrait of a changing southern State, 1975: Chapel Hill, University of North Carolina Press, p. 92-111. 
Langbein, W.B., and Iseri, K.T., 1960, General introduction and hydrologic definitions: U.S. Geological Survey Water-Supply Paper 1541-A, 29 p.

Lee, W.D., 1955, The soils of North Carolina-Their formation, identification, and use: North Carolina Agricultural Experiment Station Technical Bulletin No. $115,187 \mathrm{p}$.

McMahon, Gerard, and Lloyd, O.B., Jr., 1995, Water-quality assessment of the Albemarle-Pamlico drainage basin, North Carolina and Virginia-Environmental setting and water-quality issues: U.S. Geological Survey Open-File Report 95-136, 72 p.

Mitchell, W.B., Guptill, S.C., Anderson, K.E., Fegras, R.G., and Hallam, C.A., 1977, GIRAS-A geographic information and retrieval system for handling land use and land cover data: U.S. Geological Survey Professional Paper 1059, $16 \mathrm{p}$.

Musgrave, G.W., 1955, How much of the rain enters the soil? in Water-The yearbook of agriculture, 1955: U.S. Department of Agriculture, p. 151-159.

Musgrave, G.W., and Holtan, H.N., 1964, Infiltration, in Te Chow, Ven, ed., Handbook of applied hydrology-A compendium of water-resources technology: New York, McGraw-Hill, Section 12, p. 12-26.

National Oceanic and Atmospheric Administration, 1996, Climatological data annual summary: North Carolina: National Oceanic and Atmospheric Administration, issued annually.

Nelms, D.L., Harlow, G.E., Jr., and Hayes, D.C., 1995, Baseflow characteristics of streams in the Valley and Ridge, Blue Ridge, and Piedmont physiographic provinces of Virginia: U.S. Geological Survey Open-File Report 95-298, $52 \mathrm{p}$.

North Carolina Department of Environment, Health, and Natural Resources, 1992, North Carolina lake assessment report: Division of Environmental Management, Water Quality Section, Report 92-02, $353 \mathrm{p}$.

North Carolina Department of Environment, Health, and Natural Resources, 1993, Neuse River basin-wide water quality management plan: Division of Environmental Management, $177 \mathrm{p}$.

North Carolina Geological Survey, comp., 1985, Geologic map of North Carolina: North Carolina Department of Natural Resources and Community Development, Division of Land Resources, 1 sheet, scale 1:500,000.

Outlaw, G.S., and Weaver, J.D., 1996, Flow duration and low flows of Tennessee streams through 1992: U.S. Geological Survey Water-Resources Investigations Report 95-4293, $245 \mathrm{p}$.

Powell, W.S., 1968, The North Carolina gazetteer: Chapel Hill, University of North Carolina Press, 561 p.
Riggs, H.C., 1968, Frequency curves: U.S. Geological Survey Techniques of Water-Resources Investigations, book 4, chap. A2, 15 p.

1972, Low-flow investigations: U.S. Geological Survey Techniques of Water-Resources Investigations, book 4, chap. B1, 15 p.

1973, Regional analyses of streamflow characteristics: U.S. Geological Survey Techniques of WaterResources Investigations, book 4, chap. B3, 15 p.

Seaber, P.R., Kapinos, F.P., and Knapp, G.L., 1987, Hydrologic unit maps: U.S. Geological Survey WaterSupply Paper 2294, 63 p.

Stedinger, J.R., and Thomas, W.O., Jr., 1985, Low-flow frequency estimation using base-flow measurements: U.S. Geological Survey Open-File Report 85-95, 22 p.

Strickland, A.G., and Bales, J.D., 1994, Simulation of unsteady flow in the Roanoke River from near Oak City to Williamston: U.S. Geological Survey Water-Supply Paper 2408-A, $34 \mathrm{p}$.

Stuckey, J.L., 1965, North Carolina-Its geology and mineral resources: Raleigh, North Carolina Department of Conservation and Development, $550 \mathrm{p}$.

Tant, P.L., Byrd, H.J., and Horton, R.E., 1974, General soil map of North Carolina: U.S. Department of Agriculture, Soil Conservation Service map, 1 sheet, scale $1: 1,000,000$.

Telis, P.A., 1991, Low-flow and flow-duration characteristics of Mississippi streams: U.S. Geological Survey WaterResources Investigations Report 90-4087, 214 p. 1992, Techniques for estimating 7-day, 10-year lowflow characteristics for ungaged sites on streams in Mississippi: U.S. Geological Survey Water-Resources Investigations Report 91-4130, 143 p.

Terziotti, Silvia, Schrader, T.P., and Treece, M.W., Jr., 1994, Estimated water use, by county, in North Carolina, 1990: U.S. Geological Survey Open-File Report 94-522, $102 \mathrm{p}$.

U.S. Department of Agriculture, 1912, Soil survey of Granville County, North Carolina: Bureau of Soils, $44 \mathrm{p}$.

1970, Soil survey of Wake County, North Carolina:

Soil Conservation Service, 118 p.

1974a, Soil survey of Pitt County, North Carolina:

Soil Conservation Service, $73 \mathrm{p}$.

- 1974b, Soil survey of Wayne County, North

Carolina: Soil Conservation Service, $72 \mathrm{p}$.

1976, Soil survey of Durham County, North

Carolina: Soil Conservation Service, 74 p.

1977a, Soil survey of Lenoir County, North

Carolina: Soil Conservation Service, 66 p.

1977b, Soil survey of Orange County, North

Carolina: Soil Conservation Service, 93 p. 
1980, Soil survey of Greene County, North Carolina:

Soil Conservation Service, $83 \mathrm{p}$.

1981, Soil survey of Jones County, North Carolina:

Soil Conservation Service, $98 \mathrm{p}$.

-1983, Soil survey of Wilson County, North Carolina:

Soil Conservation Service, $112 \mathrm{p}$.

1987, Soil survey of Pamlico County,

North Carolina: Soil Conservation Service,

$133 \mathrm{p}$.

1989a, Soil survey of Craven County,

North Carolina: Soil Conservation Service,

$157 \mathrm{p}$.

1989b, Soil survey of Nash County, North Carolina:

Soil Conservation Service, $127 \mathrm{p}$.

- 1994, Soil survey of Johnston County,

North Carolina: Soil Conservation Service,

$162 \mathrm{p}$.

1995, Soil survey of Person County, North Carolina:

Soil Conservation Service, $160 \mathrm{p}$.

U.S. Geological Survey, 1961-96, Water resources data for

North Carolina: U.S. Geological Survey Water-Data

Report, published annually.

_ 1974, Hydrologic unit map: State of North Carolina: 1 sheet, scale 1:500,000.

Vogelmann, J.E., Sohl, T.L., Campbell, P.V., and Shaw, D.M., 1998, Regional land cover characterization using Landsat Thematic data and ancillary data sources, in Environmental Monitoring and Assessment, v. 51, p. $415-428$.
Weaver, J.C., 1996, Low-flow characteristics and profiles for selected streams in the Roanoke River Basin, North Carolina: U.S. Geological Survey Water-Resources Investigations Report 96-4154, $56 \mathrm{p}$.

1997, Low-flow characteristics and profiles for the Deep River in the Cape Fear River Basin, North Carolina: U.S. Geological Survey Water-Resources Investigations Report 97-4128, 31 p.

Winner, M.D., Jr., and Coble R.W., 1996, Hydrogeologic framework of the North Carolina Coastal Plain: U.S. Geological Survey Professional Paper 1404-I, 106 p., 24 pls. in pocket.

Yonts, W.L., 1971, Low-flow measurements of North Carolina streams: Raleigh, North Carolina Department of Water and Air Resources, $236 \mathrm{p}$.

Yonts, W.L., Giese, G.L., and Hubbard, E.F., 1973, Evaporation from Lake Michie, North Carolina 1961-71: U.S. Geological Survey Water-Resources Investigations $38-73,27 \mathrm{p}$.

Zalants, M.G., 1991, Low-flow frequency and flow duration of selected South Carolina streams through 1987: U.S. Geological Survey Water-Resources Investigations Report 91-4170, $87 \mathrm{p}$.

Zembrzuski, T.J., Jr., Hill, C.L., Weaver, J.C., Coble, R.W., and Gunter, H.C., 1991, North Carolina floods and droughts, in National Water Summary 198889-Hydrologic events and floods and droughts: U.S. Geological Survey Water-Supply Paper 2375, p. $425-434$. 
Table 5. Summary of continuous-record gaging stations and partial-record measuring sites in the Neuse River Basin in North Carolina where records of gage height 5 and streamflow were collected

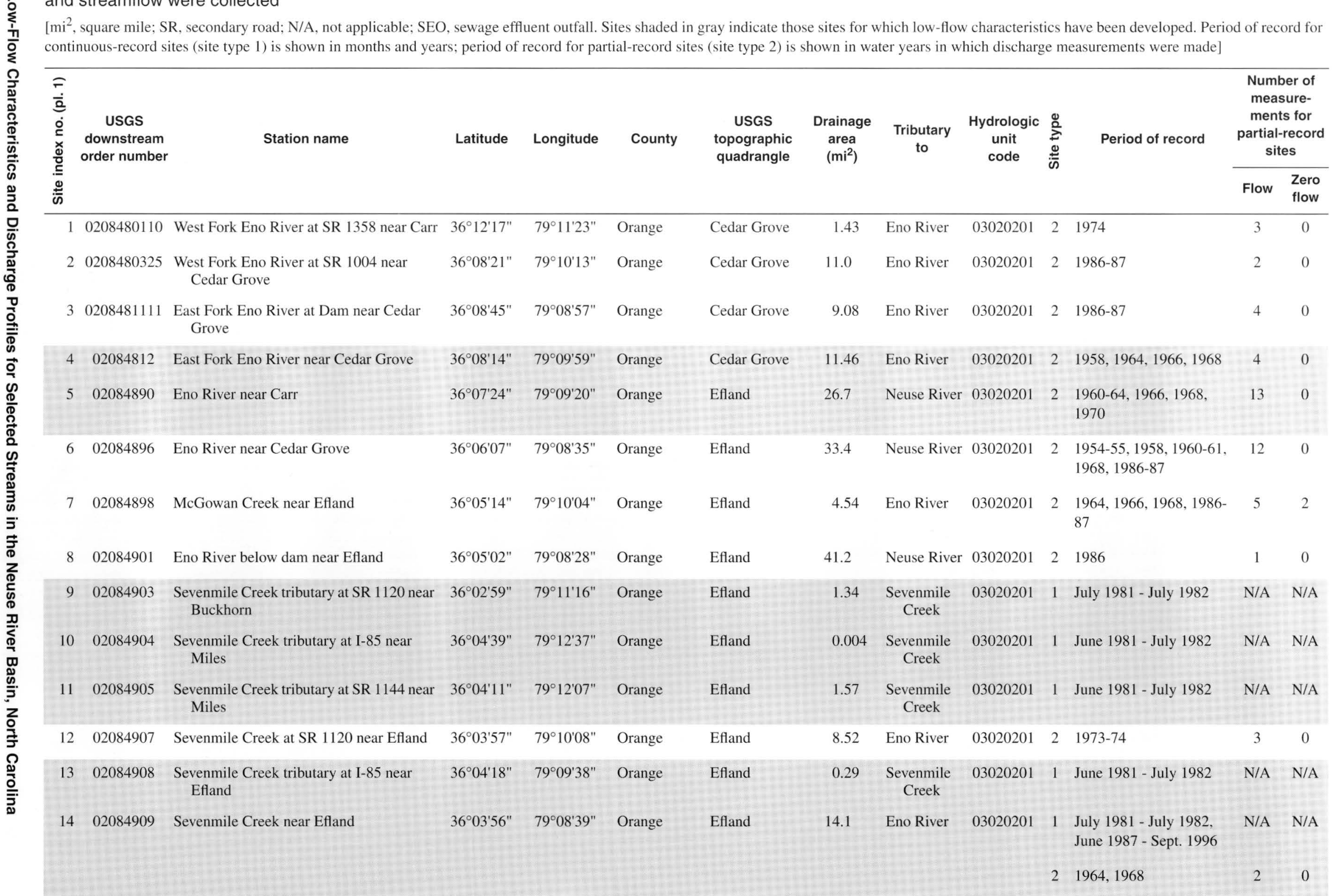


Table 5. Summary of continuous-record gaging stations and partial-record measuring sites in the Neuse River Basin in North Carolina where records of gage height and streamflow were collected-Continued

$\left[\mathrm{mi}^{2}\right.$, square mile; SR, secondary road; N/A, not applicable; SEO, sewage effluent outfall. Sites shaded in gray indicate those sites for which low-flow characteristics have been developed. Period of record for continuous-record sites (site type 1) is shown in months and years; period of record for partial-record sites (site type 2) is shown in water years in which discharge measurements were made]

\begin{tabular}{|c|c|c|c|c|c|c|c|c|c|c|c|c|c|}
\hline \multirow{2}{*}{ 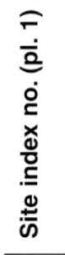 } & \multirow[t]{2}{*}{$\begin{array}{l}\text { USGS } \\
\text { downstream } \\
\text { order number }\end{array}$} & \multirow[t]{2}{*}{ Station name } & \multirow[t]{2}{*}{ Latitude } & \multirow[t]{2}{*}{ Longitude } & \multirow[t]{2}{*}{ County } & \multirow[t]{2}{*}{$\begin{array}{c}\text { USGS } \\
\text { topographic } \\
\text { quadrangle }\end{array}$} & \multirow[t]{2}{*}{$\begin{array}{l}\text { Drainage } \\
\text { area } \\
\left(\mathrm{mi}^{2}\right)\end{array}$} & \multirow[t]{2}{*}{$\begin{array}{l}\text { Tributary } \\
\text { to }\end{array}$} & \multirow[t]{2}{*}{$\begin{array}{l}\text { Hydrologic } \\
\text { unit } \\
\text { code }\end{array}$} & \multirow[t]{2}{*}{$\begin{array}{l}\stackrel{0}{2} \\
\frac{0}{0} \\
\stackrel{0}{0}\end{array}$} & \multirow[t]{2}{*}{ Period of record } & \multicolumn{2}{|c|}{$\begin{array}{c}\text { Number of } \\
\text { measure- } \\
\text { ments for } \\
\text { partial-recorc } \\
\text { sites }\end{array}$} \\
\hline & & & & & & & & & & & & Flow & $\begin{array}{l}\text { Zero } \\
\text { flow }\end{array}$ \\
\hline 15 & 02084910 & Rocky Run near Hillsborough & $36^{\circ} 03^{\prime} 44^{\prime \prime}$ & $79^{\circ} 08^{\prime} 15^{\prime \prime}$ & Orange & Efland & 2.53 & $\begin{array}{l}\text { Sevenmile } \\
\text { Creek }\end{array}$ & 03020201 & 2 & $1964,1968,1986-87$ & 4 & 0 \\
\hline 16 & 02084911 & Sevenmile Creek near Hillsborough & $36^{\circ} 04^{\prime} 14^{\prime \prime}$ & $79^{\circ} 08^{\prime} 09^{\prime \prime}$ & Orange & Efland & 17.1 & Eno River & 03020201 & 2 & $1954,1958,1968$ & 3 & 1 \\
\hline 17 & 0208491175 & Eno River at dam near Hillsborough & $36^{\circ} 04^{\prime} 15^{\prime \prime}$ & $79^{\circ} 071^{\prime} 51^{\prime \prime}$ & Orange & Efland & 59.9 & Neuse River & 03020201 & 2 & 1986 & 1 & 0 \\
\hline 18 & 02084916 & $\begin{array}{l}\text { Eno River at water-supply intake near } \\
\text { Hillsborough }\end{array}$ & $36^{\circ} 04^{\prime} 13^{\prime \prime}$ & $79^{\circ} 07^{\prime} 47^{\prime \prime}$ & Orange & Efland & 60.4 & Neuse River & 03020201 & 2 & $\begin{array}{l}1954-55,1958,1968 \\
1974-75\end{array}$ & 9 & 0 \\
\hline 19 & 02084917 & Eno River tributary no. 2 at Hillsborough & $36^{\circ} 03^{\prime} 35^{\prime \prime}$ & $79^{\circ} 07^{\prime} 53^{\prime \prime}$ & Orange & Efland & 1.42 & Eno River & 03020201 & 2 & 1964, 1968 & 2 & 1 \\
\hline 20 & 02085000 & Eno River at Hillsborough & $36^{\circ} 04^{\prime} 18^{\prime \prime}$ & $79^{\circ} 05^{\prime} 49^{\prime \prime}$ & Orange & Hillsborough & 66.0 & Neuse River & 03020201 & 1 & $\begin{array}{l}\text { Oct. } 1927 \text { - Sept. } 1971 \text {, } \\
\text { Oct. } 1985 \text { - Sept. } 1996\end{array}$ & N/A & $\mathrm{N} / \mathrm{A}$ \\
\hline 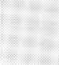 & & & & & & & & & & 2 & 1973 & 4 & 0 \\
\hline 21 & 0208500575 & Cates Creek at SR 1200 near Hillsborough & $36^{\circ} 03^{\prime} 42^{\prime \prime}$ & $79^{\circ} 05^{\prime 2} 27^{\prime \prime}$ & Orange & Hillsborough & 4.45 & Eno River & 03020201 & 2 & 1973-74 & 4 & 0 \\
\hline 22 & 02085006 & Cates Creek near Hillsborough & $36^{\circ} 03^{\prime} 55^{\prime \prime}$ & $79^{\circ} 05^{\prime} 14^{\prime \prime}$ & Orange & Hillsborough & 4.18 & Eno River & 03020201 & 2 & $\begin{array}{l}1954-55,1968,1970 \\
1973-74\end{array}$ & 10 & 2 \\
\hline 23 & 02085011 & Eno River at U.S. 70 near Hillsborough & $36^{\circ} 04^{\prime} 32^{\prime \prime}$ & $79^{\circ} 04^{\prime} 17^{\prime \prime}$ & Orange & Hillsborough & 73.2 & Neuse River & 03020201 & 2 & $1972-73$ & 3 & 0 \\
\hline 24 & 0208501550 & Eno River at SR 1561 near Hillsborough & $36^{\circ} 05^{\prime} 06^{\prime \prime}$ & $79^{\circ} 03^{\prime} 43^{\prime \prime}$ & Orange & Hillsborough & 82.5 & Neuse River & 03020201 & 2 & 1973 & 5 & 0 \\
\hline 25 & 02085016 & Eno River near Schley & $36^{\circ} 04^{\prime} 45^{\prime \prime}$ & $79^{\circ} 00^{\prime} 28^{\prime \prime}$ & Orange & Hillsborough & 99.4 & Neuse River & 03020201 & 2 & $\begin{array}{l}\text { 1954-55, 1964, 1966, } \\
1968,1973\end{array}$ & 9 & 0 \\
\hline 26 & 02085020 & Stony Creek tributary near Hillsborough & $36^{\circ} 03^{\prime} 01^{\prime \prime}$ & $79^{\circ} 02^{\prime} 14^{\prime \prime}$ & Orange & Hillsborough & 0.8 & Stony Creek & 03020201 & 2 & $1959,1961-71$ & 12 & 0 \\
\hline 27 & 02085028 & Stony Creek at University & $36^{\circ} 02^{\prime} 18^{\prime \prime}$ & $79^{\circ} 02^{\prime} 05^{\prime \prime}$ & Orange & Hillsborough & 6.61 & Eno River & 03020201 & 2 & 1964, 1966 & 2 & 0 \\
\hline 28 & 02085029 & $\begin{array}{l}\text { Stony Creek tributary at SR } 1712 \text { at } \\
\text { University }\end{array}$ & $36^{\circ} 02^{\prime} 39^{\prime \prime}$ & $79^{\circ} 01^{\prime} 35^{\prime \prime}$ & Orange & Hillsborough & 1.33 & Stony Creek & 03020201 & 2 & 1973-74 & 4 & 0 \\
\hline 29 & 02085034 & Eno River near University & $36^{\circ} 02^{\prime} 47^{\prime \prime}$ & $79^{\circ} 00^{\prime} 40^{\prime \prime}$ & Orange & Hillsborough & 113 & Neuse River & 03020201 & 2 & $1973,1976,1978,1980$ & 9 & 0 \\
\hline 30 & 0208503880 & Eno River at SR 1568 near University & $36^{\circ} 02^{\prime} 42^{\prime \prime}$ & $78^{\circ} 59^{\prime} 23^{\prime \prime}$ & Orange & $\begin{array}{r}\text { Northwest } \\
\text { Durham }\end{array}$ & $120^{\mathrm{a}}$ & Neuse River & 03020201 & 2 & 1973,1975 & 3 & 0 \\
\hline
\end{tabular}




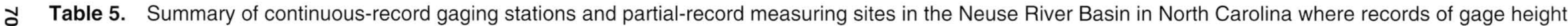
and streamflow were collected-Continued

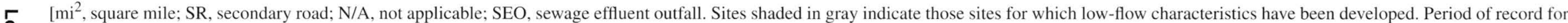
continuous-record sites (site type 1) is shown in months and years; period of record for partial-record sites (site type 2) is shown in water years in which discharge measurements were made]

\begin{tabular}{|c|c|c|c|c|c|c|c|c|c|c|c|c|c|}
\hline \multirow{2}{*}{ 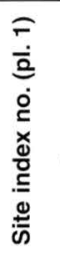 } & \multirow[t]{2}{*}{$\begin{array}{c}\text { USGS } \\
\text { downstream } \\
\text { order number }\end{array}$} & \multirow[t]{2}{*}{ Station name } & \multirow[t]{2}{*}{ Latitude } & \multirow[t]{2}{*}{ Longitude } & \multirow[t]{2}{*}{ County } & \multirow[t]{2}{*}{$\begin{array}{c}\text { USGS } \\
\text { topographic } \\
\text { quadrangle }\end{array}$} & \multirow[t]{2}{*}{$\begin{array}{c}\text { Drainage } \\
\text { area } \\
\left(\mathrm{mi}^{2}\right)\end{array}$} & \multirow[t]{2}{*}{$\begin{array}{l}\text { Tributary } \\
\text { to }\end{array}$} & \multirow[t]{2}{*}{$\begin{array}{l}\text { Hydrologic } \\
\text { unit } \\
\text { code }\end{array}$} & \multirow[t]{2}{*}{\begin{tabular}{l}
0 \\
$\sum_{2}^{0}$ \\
\multirow{2}{0}{} \\
के
\end{tabular}} & \multirow[t]{2}{*}{ Period of record } & \multicolumn{2}{|c|}{$\begin{array}{l}\text { Number of } \\
\text { measure- } \\
\text { ments for } \\
\text { partial-record } \\
\text { sites }\end{array}$} \\
\hline & & & & & & & & & & & & Flow & $\begin{array}{l}\text { Zero } \\
\text { flow }\end{array}$ \\
\hline 31 & 02085039 & Eno River near Huckleberry Spring & $36^{\circ} 03^{\prime} 37^{\prime \prime}$ & $78^{\circ} 58^{\prime} 42^{\prime \prime}$ & Durham & $\begin{array}{l}\text { Northwest } \\
\text { Durham }\end{array}$ & 121 & Neuse River & 03020201 & 2 & 1973-75, 1978 & 5 & 0 \\
\hline 32 & 0208503930 & $\begin{array}{l}\text { Eno River at SR } 1403 \text { near Huckleberry } \\
\text { Spring }\end{array}$ & $36^{\circ} 03^{\prime} 45^{\prime \prime}$ & $78^{\circ} 57^{\prime} 45^{\prime \prime}$ & Durham & $\begin{array}{r}\text { Northwest } \\
\text { Durham }\end{array}$ & 124.2 & Neuse River & 03020201 & 2 & 1973-74 & 3 & 0 \\
\hline 33 & 02085049 & Eno River at SR 1003 near Durham & $36^{\circ} 04^{\prime} 18^{\prime \prime}$ & $78^{\circ} 56^{\prime} 06^{\prime \prime}$ & Durham & $\begin{array}{l}\text { Northwest } \\
\text { Durham }\end{array}$ & $130^{\mathrm{a}}$ & Neuse River & 03020201 & 2 & $1973-75$ & 4 & 0 \\
\hline 34 & 02085056 & $\begin{array}{l}\text { Warren Creek tributary near Huckleberry } \\
\text { Spring }\end{array}$ & $36^{\circ} 03^{\prime} 19^{\prime \prime}$ & $78^{\circ} 56^{\prime} 09^{\prime \prime}$ & Durham & Durham North & $0.9^{\mathrm{a}}$ & $\begin{array}{l}\text { Warren } \\
\text { Creek }\end{array}$ & 03020201 & 2 & 1973-74 & 3 & 0 \\
\hline 35 & 02085059 & Crooked Creek near Durham & $36^{\circ} 04^{\prime} 38^{\prime \prime}$ & $78^{\circ} 55^{\prime} 04^{\prime \prime}$ & Durham & $\begin{array}{r}\text { Northwest } \\
\text { Durham }\end{array}$ & 4.56 & Neuse River & 03020201 & 2 & $1958,1964,1966,1968$ & 4 & 1 \\
\hline \multirow[t]{2}{*}{36} & 02085070 & Eno River near Durham & $36^{\circ} 04^{\prime} 20^{\prime \prime}$ & $78^{\circ} 54^{\prime} 30^{\prime \prime}$ & Durham & $\begin{array}{r}\text { Northwest } \\
\text { Durham }\end{array}$ & 141 & Neuse River & 03020201 & 1 & Aug. 1963 - Sept. 1996 & N/A & N/A \\
\hline & & & & & & & & & & 2 & 1963 & 1 & 0 \\
\hline 37 & 02085079 & Eno River near Weaver & $36^{\circ} 04^{\prime} 19^{\prime \prime}$ & $78^{\circ} 51^{\prime} 47^{\prime \prime}$ & Durham & $\begin{array}{l}\text { Northeast } \\
\text { Durham }\end{array}$ & 148 & Neuse River & 03020201 & 2 & $\begin{array}{l}1954-55,1958,1968 \\
1972-74,1976,1978- \\
80^{b}, 1983-87,1989-96\end{array}$ & 167 & 2 \\
\hline 38 & 02085111 & South Fork Little River near Caldwell & $36^{\circ} 09^{\prime} 27^{\prime \prime}$ & $79^{\circ} 00^{\prime} 58^{\prime \prime}$ & Orange & Caldwell & 22.7 & Little River & 03020201 & 2 & $1958,1964,1966,1968$ & 4 & 0 \\
\hline 39 & 02085114 & Forrest Creek near Cedar Grove & $36^{\circ} 08^{\prime} 18^{\prime \prime}$ & $79^{\circ} 0628^{\prime \prime}$ & Orange & Caldwell & 0.62 & $\begin{array}{l}\text { South Fork } \\
\text { Little } \\
\text { River }\end{array}$ & 03020201 & 2 & $\begin{array}{l}\text { 1954, 1964, 1966, 1968, } \\
1972-73\end{array}$ & 10 & 2 \\
\hline 40 & 02085118 & Forrest Creek near Schley & $36^{\circ} 08^{\prime} 21^{\prime \prime}$ & $79^{\circ} 04^{\prime} 53^{\prime \prime}$ & Orange & Caldwell & 3.00 & $\begin{array}{l}\text { South Fork } \\
\text { Little } \\
\text { River }\end{array}$ & 03020201 & 2 & $1954,1968,1972-73$ & 10 & 2 \\
\hline 41 & 02085124 & Forrest Creek near Hillsborough & $36^{\circ} 08^{\prime} 24^{\prime \prime}$ & $79^{\circ} 01^{\prime} 30^{\prime \prime}$ & Orange & Caldwell & 7.32 & $\begin{array}{l}\text { South Fork } \\
\text { Little } \\
\text { River }\end{array}$ & 03020201 & 2 & $1954,1958,1968$ & 4 & 1 \\
\hline 42 & 02085130 & South Fork Little River near Quail Roost & $36^{\circ} 08^{\prime} 44^{\prime \prime}$ & $78^{\circ} 57^{\prime} 44^{\prime \prime}$ & Durham & Rougemont & 38.2 & Little River & 03020201 & 2 & $1954,1958,1961-68$ & 24 & 0 \\
\hline 43 & 02085134 & $\begin{array}{l}\text { South Fork Little River near Orange } \\
\text { Factory }\end{array}$ & $36^{\circ} 08^{\prime} 57^{\prime \prime}$ & $78^{\circ} 56^{\prime} 50^{\prime \prime}$ & Durham & Rougemont & 39.0 & Little River & 03020201 & 2 & 1964 & 1 & 0 \\
\hline
\end{tabular}


Table 5. Summary of continuous-record gaging stations and partial-record measuring sites in the Neuse River Basin in North Carolina where records of gage height and streamflow were collected-Continued

$\left[\mathrm{mi}^{2}\right.$, square mile; SR, secondary road; N/A, not applicable; SEO, sewage effluent outfall. Sites shaded in gray indicate those sites for which low-flow characteristics have been developed. Period of record for continuous-record sites (site type 1) is shown in months and years; period of record for partial-record sites (site type 2) is shown in water years in which discharge measurements were made]

\begin{tabular}{|c|c|c|c|c|c|c|c|c|c|c|c|c|c|}
\hline \multirow{2}{*}{ 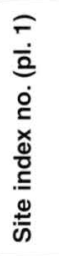 } & \multirow[t]{2}{*}{$\begin{array}{c}\text { USGS } \\
\text { downstream } \\
\text { order number }\end{array}$} & \multirow[t]{2}{*}{ Station name } & \multirow[t]{2}{*}{ Latitude } & \multirow[t]{2}{*}{ Longitude } & \multirow[t]{2}{*}{ County } & \multirow[t]{2}{*}{$\begin{array}{c}\text { USGS } \\
\text { topographic } \\
\text { quadrangle }\end{array}$} & \multirow[t]{2}{*}{$\begin{array}{c}\text { Drainage } \\
\text { area } \\
\left(\mathrm{mi}^{2}\right)\end{array}$} & \multirow[t]{2}{*}{$\begin{array}{l}\text { Tributary } \\
\text { to }\end{array}$} & \multirow[t]{2}{*}{$\begin{array}{l}\text { Hydrologic } \\
\text { unit } \\
\text { code }\end{array}$} & \multirow[t]{2}{*}{$\sum_{\substack{0 \\
\vdots}}^{\infty}$} & \multirow[t]{2}{*}{ Period of record } & \multicolumn{2}{|c|}{$\begin{array}{c}\text { Number of } \\
\text { measure- } \\
\text { ments for } \\
\text { partial-record } \\
\text { sites }\end{array}$} \\
\hline & & & & & & & & & & & & Flow & $\begin{array}{l}\text { Zero } \\
\text { flow }\end{array}$ \\
\hline 44 & 02085169 & North Fork Little River near Caldwell & $36^{\circ} 11^{\prime} 03^{\prime \prime}$ & $79^{\circ} 01^{\prime} 26^{\prime \prime}$ & Orange & Caldwell & 13.3 & Little River & 03020201 & 2 & $1958,1964,1966,1968$ & 4 & 1 \\
\hline 45 & 02085190 & $\begin{array}{l}\text { North Fork Little River tributary near } \\
\text { Rougemont }\end{array}$ & $36^{\circ} 11^{\prime} 41^{\prime \prime}$ & $79^{\circ} 00^{\prime} 43^{\prime \prime}$ & Orange & Caldwell & 1.00 & $\begin{array}{l}\text { North Fork } \\
\text { Little } \\
\text { River }\end{array}$ & 03020201 & 2 & $1953,1961-76$ & 22 & 4 \\
\hline 46 & 02085196 & North Fork Little River near Schley & $36^{\circ} 10^{\prime} 50^{\prime \prime}$ & $78^{\circ} 58^{\prime} 31^{\prime \prime}$ & Orange & Rougemont & 20.3 & Little River & 03020201 & 2 & $1958,1964,1966,1968$ & 4 & 1 \\
\hline 47 & 02085201 & Buffalo Creek near Rougemont & $36^{\circ} 11^{\prime} 05^{\prime \prime}$ & $78^{\circ} 57^{\prime} 04^{\prime \prime}$ & Durham & Rougemont & 5.48 & $\begin{array}{l}\text { North Fork } \\
\text { Little } \\
\text { River }\end{array}$ & 03020201 & 2 & 1958, 1964, 1966, 1968 & 4 & 3 \\
\hline 48 & 02085210 & $\begin{array}{l}\text { North Fork Little River near Orange } \\
\text { Factory }\end{array}$ & $36^{\circ} 09^{\prime} 48^{\prime \prime}$ & $78^{\circ} 566^{\prime \prime}$ & Durham & Rougemont & 29.7 & Little River & 03020201 & 2 & $1954,1961-68$ & 23 & 1 \\
\hline 49 & 0208521240 & Little River tributary near Fox Run & $36^{\circ} 08^{\prime} 34^{\prime \prime}$ & $78^{\circ} 55^{\prime} 26^{\prime \prime}$ & Orange & Rougemont & 0.43 & Little River & 03020201 & 2 & 1986 & 1 & 1 \\
\hline 50 & 0208521324 & $\begin{array}{l}\text { Little River at SR } 1461 \text { near Orange } \\
\quad \text { Factory }\end{array}$ & $36^{\circ} 08^{\prime} 30^{\prime \prime}$ & $78^{\circ} 55^{\prime} 10^{\prime \prime}$ & Durham & Rougemont & 78.2 & Eno River & 03020201 & 1 & Oct. 1987 - Sept. 1996 & N/A & N/A \\
\hline 51 & 02085220 & Little River near Orange Factory & $36^{\circ} 08^{\prime} 20^{\prime \prime}$ & $78^{\circ} 54^{\prime} 24^{\prime \prime}$ & Durham & Rougemont & 80.4 & Eno River & 03020201 & 1 & Sept. 1961 - Sept. 1987 & N/A & N/A \\
\hline & & & & & & & & & & 2 & $1930,1954-59,1961$ & 19 & 0 \\
\hline 52 & 0208524090 & Mountain Creek at SR 1617 near Bahama & $36^{\circ} 08^{\prime} 58^{\prime \prime}$ & $78^{\circ} 53^{\prime} 49^{\prime \prime}$ & Durham & Rougemont & 8.0 & Little River & 03020201 & 1 & Oct. 1994 - Sept. 1996 & N/A & N/A \\
\hline 53 & 02085241 & Mountain Creek near Orange Factory & $36^{\circ} 08^{\prime} 42^{\prime \prime}$ & $78^{\circ} 53^{\prime} 32^{\prime \prime}$ & Durham & Durham North & 8.47 & Little River & 03020201 & 2 & $1958,1964,1966,1968$ & 4 & 1 \\
\hline 54 & 0208524950 & Little River tributary at Fairntosh & $36^{\circ} 06^{\prime} 56^{\prime \prime}$ & $78^{\circ} 51^{\prime} 30^{\prime \prime}$ & Durham & $\begin{array}{l}\text { Northeast } \\
\text { Durham }\end{array}$ & 0.86 & Little River & 03020201 & 2 & $1994-96^{\mathrm{C}}$ & 28 & 0 \\
\hline 55 & 0208524975 & $\begin{array}{l}\text { Little River below Little River tributary at } \\
\text { Fairntosh }\end{array}$ & $36^{\circ} 06^{\prime} 46^{\prime \prime}$ & $78^{\circ} 51^{\prime} 35^{\prime \prime}$ & Durham & $\begin{array}{l}\text { Northeast } \\
\text { Durham }\end{array}$ & 98.9 & Neuse River & 03020201 & 1 & Oct. 1995 - Sept. 1996 & N/A & N/A \\
\hline 56 & 02085262 & Little River near Weaver & $36^{\circ} 04^{\prime} 56^{\prime \prime}$ & $78^{\circ} 51^{\prime} 25^{\prime \prime}$ & Durham & $\begin{array}{l}\text { Northeast } \\
\text { Durham }\end{array}$ & 104 & Eno River & 03020201 & 2 & $\begin{array}{l}1954,1958,1964,1966, \\
1968,1970\end{array}$ & 6 & 0 \\
\hline 57 & 02085284 & Eno River near Willardville & $36^{\circ} 05^{\prime} 31^{\prime \prime}$ & $78^{\circ} 49^{\prime} 27^{\prime \prime}$ & Durham & $\begin{array}{l}\text { Northeast } \\
\text { Durham }\end{array}$ & 259 & Neuse River & 03020201 & 2 & $1954,1964,1968$ & 3 & 0 \\
\hline 58 & 02085302 & South Flat River near Hurdle Mills & $36^{\circ} 17^{\prime} 40^{\prime \prime}$ & $79^{\circ} 03^{\prime} 54^{\prime \prime}$ & Person & Hurdle Mills & 6.22 & Flat River & 03020201 & 2 & $1974-76,1978-84$ & 31 & 1 \\
\hline
\end{tabular}




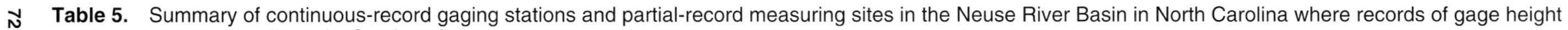
and streamflow were collected-Continued

\begin{tabular}{|c|c|c|c|c|c|c|c|c|c|c|c|c|c|}
\hline \multirow{2}{*}{ 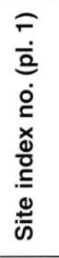 } & \multirow[t]{2}{*}{$\begin{array}{c}\text { USGS } \\
\text { downstream } \\
\text { order number }\end{array}$} & \multirow[t]{2}{*}{ Station name } & \multirow[t]{2}{*}{ Latitude } & \multirow[t]{2}{*}{ Longitude } & \multirow[t]{2}{*}{ County } & \multirow[t]{2}{*}{$\begin{array}{c}\text { USGS } \\
\text { topographic } \\
\text { quadrangle }\end{array}$} & \multirow[t]{2}{*}{$\begin{array}{c}\text { Drainage } \\
\text { area } \\
\left(\mathrm{mi}^{2}\right)\end{array}$} & \multirow[t]{2}{*}{$\begin{array}{l}\text { Tributary } \\
\text { to }\end{array}$} & \multirow[t]{2}{*}{$\begin{array}{l}\text { Hydrologic } \\
\text { unit } \\
\text { code }\end{array}$} & \multirow[t]{2}{*}{$\begin{array}{l}\sum_{2} \\
\stackrel{0}{0} \\
\text { के }\end{array}$} & \multirow[t]{2}{*}{ Period of record } & \multicolumn{2}{|c|}{$\begin{array}{l}\text { Number of } \\
\text { measure- } \\
\text { ments for } \\
\text { partial-record } \\
\text { sites }\end{array}$} \\
\hline & & & & & & & & & & & & Flow & $\begin{array}{l}\text { Zero } \\
\text { flow }\end{array}$ \\
\hline 59 & 02085306 & South Flat River at Hurdle Mills & $36^{\circ} 16^{\prime} 39^{\prime \prime}$ & $79^{\circ} 02^{\prime} 42^{\prime \prime}$ & Person & Hurdle Mills & 17.3 & Flat River & 03020201 & 2 & $1958,1964,1966$ & 3 & 0 \\
\hline 60 & 02085320 & $\begin{array}{l}\text { South Flat River at SR } 1120 \text { near Hurdle } \\
\text { Mills }\end{array}$ & $36^{\circ} 15^{\prime} 43^{\prime \prime}$ & $79^{\circ} 00^{\prime} 45^{\prime \prime}$ & Person & Hurdle Mills & 10 & Flat River & 03020201 & 2 & $1974-75,1979$ & 4 & 0 \\
\hline 61 & 02085327 & Aldridge Creek near Hurdle Mills & $36^{\circ} 16^{\prime} 39^{\prime \prime}$ & $79^{\circ} 00^{\prime} 05^{\prime \prime}$ & Person & Hurdle Mills & 9.07 & $\begin{array}{l}\text { South Flat } \\
\text { River }\end{array}$ & 03020201 & 2 & $1958,1964,1966,1968$ & 4 & 0 \\
\hline 62 & 02085348 & South Flat River near Timberlake & $36^{\circ} 15^{\prime} 25^{\prime \prime}$ & $78^{\circ} 57^{\prime} 48^{\prime \prime}$ & Person & Roxboro & 51.1 & Flat River & 03020201 & 2 & $1958,1964,1966,1968$ & 4 & 0 \\
\hline 63 & 0208535580 & $\begin{array}{l}\text { North Flat River at SR } 1142 \text { near } \\
\text { Roseville }\end{array}$ & $36^{\circ} 20^{\prime} 30^{\prime \prime}$ & $79^{\circ} 01^{\prime} 29^{\prime \prime}$ & Person & Hurdle Mills & 5.27 & Flat River & 03020201 & 2 & $1974,1976,1980$ & 7 & 0 \\
\hline 64 & 02085356 & North Flat River near Paynes Tavern & $36^{\circ} 20^{\prime} 06^{\prime \prime}$ & $79^{\circ} 00^{\prime} 49^{\prime \prime}$ & Person & Hurdle Mills & 6.54 & Flat River & 03020201 & 2 & 1964, 1966, 1968 & 3 & 1 \\
\hline 65 & 02085357 & $\begin{array}{l}\text { North Flat River tributary } 2 \text { at Allens } \\
\text { Level }\end{array}$ & $36^{\circ} 20^{\prime} 00^{\prime \prime}$ & $79^{\circ} 01^{\prime} 00^{\prime \prime}$ & Person & Hurdle Mills & 0.47 & $\begin{array}{l}\text { North Flat } \\
\text { River }\end{array}$ & 03020201 & 2 & 1968 & 1 & 1 \\
\hline 66 & 0208535888 & $\begin{array}{l}\text { North Flat River tributary at SR } 1195 \text { at } \\
\text { Roxboro }\end{array}$ & $36^{\circ} 21^{\prime} 50^{\prime \prime}$ & $78^{\circ} 59^{\prime} 23^{\prime \prime}$ & Person & Roxboro & 0.2 & Flat River & 03020201 & 2 & 1974-75 & 6 & 0 \\
\hline 67 & 0208535895 & $\begin{array}{l}\text { Unnamed tributary to North Flat River } \\
\text { near Roxboro }\end{array}$ & $36^{\circ} 22^{\prime} 30^{\prime \prime}$ & $78^{\circ} 59^{\prime} 40^{\prime \prime}$ & Person & Roxboro & $1^{\mathrm{a}}$ & $\begin{array}{l}\text { North Flat } \\
\text { River }\end{array}$ & 03020201 & 2 & 1974-75 & 3 & 0 \\
\hline 68 & 02085369 & North Flat River near Allens Level & $36^{\circ} 19^{\prime} 20^{\prime \prime}$ & $78^{\circ} 59^{\prime} 30^{\prime \prime}$ & Person & Roxboro & 14.2 & Flat River & 03020201 & 2 & 1958,1966 & 2 & 0 \\
\hline 69 & 02085390 & North Flat River at Timberlake & $36^{\circ} 17 ' 24^{\prime \prime}$ & $78^{\circ} 56^{\prime} 43^{\prime \prime}$ & Person & Timberlake & 33.0 & Flat River & 03020201 & 2 & $1958,1964-68,1970$ & 15 & 0 \\
\hline 70 & 02085413 & Deep Creek near Surl & $36^{\circ} 19^{\prime} 52^{\prime \prime}$ & $78^{\circ} 53^{\prime} 24^{\prime \prime}$ & Person & Roxboro & 11.6 & Flat River & 03020201 & 2 & $1958,1964,1966,1968$ & 4 & 3 \\
\hline 71 & 02085422 & Deep Creek near Timberlake & $36^{\circ} 16^{\prime} 15^{\prime \prime}$ & $78^{\circ} 52^{\prime} 57^{\prime \prime}$ & Person & Roxboro & 27.9 & Flat River & 03020201 & 2 & $1974-75$ & 3 & 0 \\
\hline 72 & 02085430 & Deep Creek near Moriah & $36^{\circ} 14^{\prime} 24^{\prime \prime}$ & $78^{\circ} 53^{\prime} 20^{\prime \prime}$ & Person & Rougemont & 32.5 & Flat River & 03020201 & 2 & $1958,1963-68,1970$ & 17 & 4 \\
\hline 73 & 02085477 & Flat River near Quail Roost & $36^{\circ} 12^{\prime} 00^{\prime \prime}$ & $78^{\circ} 53^{\prime} 12^{\prime \prime}$ & Durham & Rougemont & 146 & Neuse River & 03020201 & 2 & 1997 & 1 & 0 \\
\hline 74 & 02085500 & Flat River at Bahama & $36^{\circ} 10^{\prime} 57^{\prime \prime}$ & $78^{\circ} 52^{\prime} 44^{\prime \prime}$ & Durham & Rougemont & 149 & Neuse River & 03020201 & 1 & July 1925 - Sept. 1996 & N/A & N/A \\
\hline 75 & 02085810 & Muddy Branch at Bahama & $36^{\circ} 10^{\prime} 16^{\prime \prime}$ & $78^{\circ} 52^{\prime} 47^{\prime \prime}$ & Durham & Durham North & 0.64 & Flat River & 03020201 & 2 & $1961-66,1968,1970$ & 23 & 5 \\
\hline 76 & 02086000 & Dial Creek near Bahama & $36^{\circ} 10^{\prime} 36^{\prime \prime}$ & $78^{\circ} 51^{\prime} 24^{\prime \prime}$ & Durham & Lake Michie & 4.76 & Flat River & 03020201 & 1 & $\begin{array}{l}\text { Oct. } 1925 \text { - Sept. } 1971 \text {, } \\
\text { Aug. } 1989 \text { - Sept. } 1991\end{array}$ & N/A & N/A \\
\hline
\end{tabular}


Table 5. Summary of continuous-record gaging stations and partial-record measuring sites in the Neuse River Basin in North Carolina where records of gage height and streamflow were collected-Continued

$\left[\mathrm{mi}^{2}\right.$, square mile; SR, secondary road; N/A, not applicable; SEO, sewage effluent outfall. Sites shaded in gray indicate those sites for which low-flow characteristics have been developed. Period of record for continuous-record sites (site type 1) is shown in months and years; period of record for partial-record sites (site type 2) is shown in water years in which discharge measurements were made]

\begin{tabular}{|c|c|c|c|c|c|c|c|c|c|c|c|c|c|}
\hline \multirow{2}{*}{ 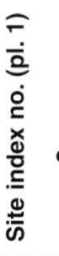 } & \multirow[t]{2}{*}{$\begin{array}{c}\text { USGS } \\
\text { downstream } \\
\text { order number }\end{array}$} & \multirow[t]{2}{*}{ Station name } & \multirow[t]{2}{*}{ Latitude } & \multirow[t]{2}{*}{ Longitude } & \multirow[t]{2}{*}{ County } & \multirow[t]{2}{*}{$\begin{array}{l}\text { USGS } \\
\text { topographic } \\
\text { quadrangle }\end{array}$} & \multirow[t]{2}{*}{$\begin{array}{l}\text { Drainage } \\
\text { area } \\
\left(\mathrm{mi}^{2}\right)\end{array}$} & \multirow[t]{2}{*}{$\begin{array}{l}\text { Tributary } \\
\text { to }\end{array}$} & \multirow[t]{2}{*}{$\begin{array}{l}\text { Hydrologic } \\
\text { unit } \\
\text { code }\end{array}$} & \multirow[t]{2}{*}{ 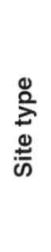 } & \multirow[t]{2}{*}{ Period of record } & \multicolumn{2}{|c|}{$\begin{array}{l}\text { Number of } \\
\text { measure- } \\
\text { ments for } \\
\text { partial-record } \\
\text { sites }\end{array}$} \\
\hline & & & & & & & & & & & & Flow & $\begin{array}{l}\text { Zero } \\
\text { flow }\end{array}$ \\
\hline 77 & 02086101 & Horner Ford Creek at Bahama & $36^{\circ} 09^{\prime} 36^{\prime \prime}$ & $78^{\circ} 52^{\prime} 27^{\prime \prime}$ & Durham & Durham North & 0.28 & $\begin{array}{l}\text { Lake } \\
\quad \text { Michie }\end{array}$ & 03020201 & 2 & $1961-64,1968,1970$ & 9 & 2 \\
\hline 78 & 02086121 & Horner Ford Creek tributary near Bahama & $36^{\circ} 09^{\prime} 29^{\prime \prime}$ & $78^{\circ} 51^{\prime} 42^{\prime \prime}$ & Durham & Durham North & 0.28 & $\begin{array}{l}\text { Horner Ford } \\
\text { Creek }\end{array}$ & 03020201 & 2 & $1961-64,1970$ & 8 & 3 \\
\hline 79 & 02086275 & Dry Creek near Bahama & $36^{\circ} 10^{\prime} 44^{\prime \prime}$ & $78^{\circ} 49^{\prime} 50^{\prime \prime}$ & Durham & Lake Michie & 1.24 & $\begin{array}{l}\text { Lake } \\
\text { Michie }\end{array}$ & 03020201 & 2 & $\begin{array}{l}1961-64,1966,1968 \\
1970\end{array}$ & 10 & 5 \\
\hline 80 & 02086287 & Dry Creek tributary near Bahama & $36^{\circ} 10^{\prime} 36^{\prime \prime}$ & $78^{\circ} 50^{\prime} 13^{\prime \prime}$ & Durham & Durham North & 0.24 & Dry Creek & 03020201 & 2 & $\begin{array}{l}1961-64,1966,1968 \\
1970\end{array}$ & 10 & 3 \\
\hline 81 & 02086291 & Dry Creek tributary no. 2 near Bahama & $36^{\circ} 10^{\prime} 28^{\prime \prime}$ & $78^{\circ} 50^{\prime} 41^{\prime \prime}$ & Durham & Durham North & 2.08 & Dry Creek & 03020201 & 2 & $\begin{array}{l}1961-64,1966,1968 \\
1970\end{array}$ & 10 & 6 \\
\hline 82 & 02086300 & Rocky Creek near Bahama & $36^{\circ} 10^{\prime} 30^{\prime \prime}$ & $78^{\circ} 49^{\prime} 20^{\prime \prime}$ & Durham & Lake Michie & 2.30 & $\begin{array}{l}\text { Lake } \\
\quad \text { Michie }\end{array}$ & 03020201 & 2 & $\begin{array}{l}1958,1961-64,1966 \\
1968,1970\end{array}$ & 11 & 1 \\
\hline 83 & 02086351 & Rocky Creek tributary near Bahama & $36^{\circ} 10^{\prime} 04^{\prime \prime}$ & $78^{\circ} 48^{\prime} 46^{\prime \prime}$ & Durham & Durham North & 0.50 & $\begin{array}{l}\text { Rocky } \\
\text { Creek }\end{array}$ & 03020201 & 2 & $1961-64,1968,1970$ & 9 & 7 \\
\hline 84 & 02086500 & Flat River at dam near Bahama & $36^{\circ} 08^{\prime} 55^{\prime \prime}$ & $78^{\circ} 49^{\prime} 43^{\prime \prime}$ & Durham & Lake Michie & 168 & Neuse River & 03020201 & 1 & $\begin{array}{l}\text { Aug. } 1925 \text { - Oct. } 1959 \text {, } \\
\text { Aug. } 1961 \text { - Sept. } 1966 \text {, } \\
\text { Oct. } 1982 \text { - Sept. } 1990 \text {, } \\
\text { Oct. } 1992 \text { - Sept. } 1993 .\end{array}$ & N/A & N/A \\
\hline & & & & & & & & & & 2 & $1991-92,1994-97$ & 7 & 0 \\
\hline 85 & 0208650112 & Flat River tributary near Willardville & $36^{\circ} 07^{\prime} 54^{\prime \prime}$ & $78^{\circ} 50^{\prime} 00^{\prime \prime}$ & Durham & Lake Michie & 1.14 & Flat River & 03020201 & 1 & $\begin{array}{l}\text { Mar. } 1988 \text { - Mar. } 1990 \text {, } \\
\text { Oct. } 1994 \text { - Sept. } 1996\end{array}$ & N/A & N/A \\
\hline 86 & 02086570 & Knap of Reeds Creek near Butner & $36^{\circ} 09^{\prime} 27^{\prime \prime}$ & $78^{\circ} 4627^{\prime \prime}$ & Granville & Lake Michie & 29.9 & Neuse River & 03020201 & 2 & $\begin{array}{l}1954-55,1958,1961-66 \\
1968-69\end{array}$ & 34 & 1 \\
\hline 87 & 02086597 & $\begin{array}{l}\text { Knap of Reeds Creek at SR } 1120 \text { near } \\
\text { Butner }\end{array}$ & $36^{\circ} 08^{\prime} 34^{\prime \prime}$ & $78^{\circ} 47^{\prime} 19^{\prime \prime}$ & Granville & Durham North & $3.8^{\mathrm{a}}$ & Neuse River & 03020201 & 2 & $1972-73$ & 7 & 0 \\
\hline 88 & 02086599 & Knap of Reeds Creek at Butner & $36^{\circ} 08^{\prime} 27^{\prime \prime}$ & $78^{\circ} 47^{\prime} 43^{\prime \prime}$ & Granville & Lake Michie & 39.8 & Neuse River & 03020201 & 2 & $1954-55$ & 4 & 0 \\
\hline
\end{tabular}




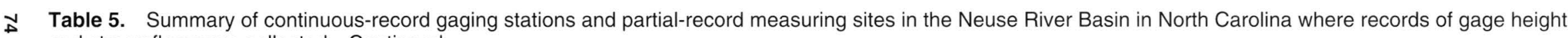
and streamflow were collected-Continued

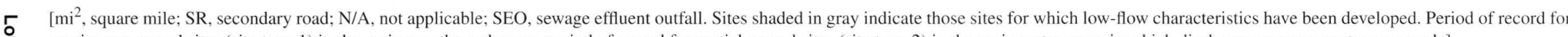
continuous-record sites (site type 1) is shown in months and years; period of record for partial-record sites (site type 2) is shown in water years in which discharge measurements were made]

Latitude Longitude

County

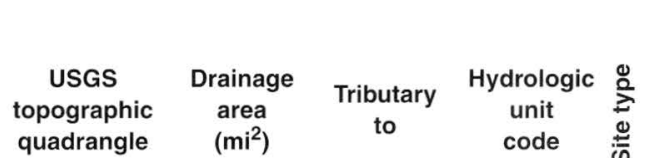

Number of

measure-

downstrea

$\stackrel{=}{ \pm}$

$89 \quad 02086624 \quad$ Knap of Reeds Creek near Butner

$36^{\circ} 07^{\prime} 40^{\prime \prime}$

$78^{\circ} 475^{\prime \prime}$

Granville

Lake Michie

Neuse River 03020201 1 Oct. $1982-$ Sept. 1995

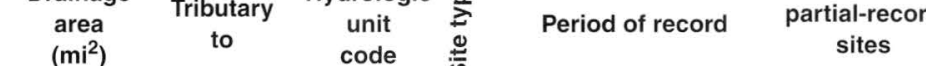

ments for

Reeds Creek tributary near

36 $07^{\prime} 13^{\prime \prime} \quad 78^{\circ} 47^{\prime} 27^{\prime \prime} \quad$ Granville Northeast

Durham

2 1980-82, 1996

sites

02086699 Ellerbe Creek near Huckleberry Springs

3601'23" $78^{\circ} 56^{\prime} 33^{\prime \prime} \quad$ Durham

Northwest

Durham

9202086720 Ellerbe Creek at Hillandale Road at Durham

9302086760 Dye Creek at Guess Road at Durham

3601'19" 78 $56^{\circ} 11^{\prime \prime} \quad$ Durham

Durham North

(1)

$36^{\circ} 01^{\prime} 09^{\prime \prime} \quad 78^{\circ} 54^{\prime} 50^{\prime \prime} \quad$ Durham

Durham North

$94 \quad 02086774$ Ellerbe Creek above Goose Creek near

36 $01^{\prime} 41^{\prime \prime} \quad 78^{\circ} 51^{\prime} 57^{\prime \prime} \quad$ Durham Durham

$9502086790 \quad$ Goose Creek at East Geer Street at Durham

9602086799 Goose Creek at Durham

970208679920 Ellerbe Creek at SR 1669 near Weaver

$98 \quad 02086824$ Ellerbe Creek below Goose Creek near Durham

9902086849 Ellerbe Creek near Gorman

360'13" 78 $52^{\prime} 50^{\prime \prime} \quad$ Durham

$36^{\circ} 01^{\prime 2} 28^{\prime \prime} \quad 78^{\circ} 51^{\prime} 39^{\prime \prime} \quad$ Durham

$36^{\circ} 01^{\prime} 41^{\prime \prime} \quad 78^{\circ} 51^{\prime} 55^{\prime \prime} \quad$ Durham

$36^{\circ} 01^{\prime} 42^{\prime \prime} \quad 78^{\circ} 51^{\prime} 54^{\prime \prime} \quad$ Durham

3603'33" 7849'58" Durham

Durham North $\quad 10.4 \quad$ Neuse River 0302020122 1951, 1964

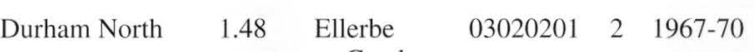

Durham North $\quad 6.55 \quad$ Ellerbe $\quad 03020201 \quad 2 \quad 1954,1964$

Northeast Durham

$17.4 \quad$ Neuse River $03020201 \quad 2 \quad 1991$

Durham North

17.1

Neuse River $03020201 \quad 2 \quad$ 1972-73 Flow $\begin{aligned} & \text { Zero } \\ & \text { flow }\end{aligned}$

(1)

$100 \quad 02086935$ Neuse River tributary at I-85 near Butner

$36^{\circ} 05^{\prime} 00^{\prime \prime} \quad 78^{\circ} 46^{\prime} 00^{\prime \prime} \quad$ Granville

Northeast

Durham

$\begin{array}{llll}5.05 & \text { Neuse River } 03020201 \quad 2 \quad 1974-75\end{array}$

Oct. 1982 - Apr. 1989 , Oct. 1991 - Sept. 1995

ortheast

2 1972-73, 1976, 1978, 1980-82, 1996

10102086949 Panther Creek at Redwood

36 $03^{\prime} 04^{\prime \prime} \quad 78^{\circ} 46^{\prime} 32^{\prime \prime} \quad$ Durham

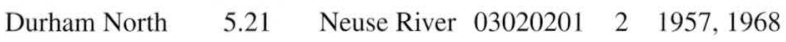
(1) 
Table 5. Summary of continuous-record gaging stations and partial-record measuring sites in the Neuse River Basin in North Carolina where records of gage height and streamflow were collected-Continued

$\left[\mathrm{mi}^{2}\right.$, square mile; SR, secondary road; N/A, not applicable; SEO, sewage effluent outfall. Sites shaded in gray indicate those sites for which low-flow characteristics have been developed. Period of record for continuous-record sites (site type 1) is shown in months and years; period of record for partial-record sites (site type 2) is shown in water years in which discharge measurements were made]

\begin{tabular}{|c|c|c|c|c|c|c|c|c|c|c|c|c|c|}
\hline \multirow{2}{*}{ 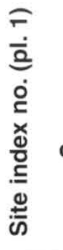 } & \multirow[t]{2}{*}{$\begin{array}{c}\text { USGS } \\
\text { downstream } \\
\text { order number }\end{array}$} & \multirow[t]{2}{*}{ Station name } & \multirow[t]{2}{*}{ Latitude } & \multirow[t]{2}{*}{ Longitude } & \multirow[t]{2}{*}{ County } & \multirow[t]{2}{*}{$\begin{array}{c}\text { USGS } \\
\text { topographic } \\
\text { quadrangle }\end{array}$} & \multirow[t]{2}{*}{$\begin{array}{c}\text { Drainage } \\
\text { area } \\
\left(\mathrm{mi}^{2}\right)\end{array}$} & \multirow[t]{2}{*}{$\begin{array}{l}\text { Tributary } \\
\text { to }\end{array}$} & \multirow[t]{2}{*}{$\begin{array}{c}\text { Hydrologic } \\
\text { unit } \\
\text { code }\end{array}$} & \multirow[t]{2}{*}{ 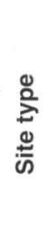 } & \multirow[t]{2}{*}{ Period of record } & \multicolumn{2}{|c|}{$\begin{array}{l}\text { Number of } \\
\text { measure- } \\
\text { ments for } \\
\text { partial-record } \\
\text { sites }\end{array}$} \\
\hline & & & & & & & & & & & & Flow & $\begin{array}{l}\text { Zero } \\
\text { flow }\end{array}$ \\
\hline 102 & 02086974 & Neuse River tributary no. 2 at Redwood & $36^{\circ} 02^{\prime} 42^{\prime \prime}$ & $78^{\circ} 46^{\prime} 05^{\prime \prime}$ & Durham & Durham North & 1.81 & Neuse River & 03020201 & 2 & 1957,1968 & 2 & 2 \\
\hline 103 & 02087000 & Neuse River near Northside & $36^{\circ} 02^{\prime} 54^{\prime \prime}$ & $78^{\circ} 44^{\prime} 59^{\prime \prime}$ & Wake & Creedmoor & 535 & Neuse River & 03020201 & 1 & July 1927 - Sept. 1980 & N/A & N/A \\
\hline 104 & 0208700550 & Little Lick Creek near Oak Grove & $35^{\circ} 58^{\prime} 56^{\prime \prime}$ & $78^{\circ} 49^{\prime} 29^{\prime \prime}$ & Durham & Durham South & $4.9^{\mathrm{a}}$ & Neuse River & 03020201 & 2 & $1972-73$ & 8 & 0 \\
\hline 105 & 0208700780 & $\begin{array}{l}\text { Little Lick Creek above SR } 1814 \text { near Oak } \\
\text { Grove }\end{array}$ & $35^{\circ} 59^{\prime} 11^{\prime \prime}$ & $78^{\circ} 47^{\prime} 58^{\prime \prime}$ & Durham & $\begin{array}{l}\text { Southeast } \\
\text { Durham }\end{array}$ & 10.1 & Neuse River & 03020201 & 1 & Oct. 1982 - Sept. 1995 & N/A & N/A \\
\hline & & & & & & & & & & 2 & 1996 & 3 & 0 \\
\hline 106 & 02087008 & $\begin{array}{l}\text { Little Lick Creek at SR } 1814 \text { near Oak } \\
\text { Grove }\end{array}$ & $35^{\circ} 59^{\prime} 11^{\prime \prime}$ & $78^{\circ} 47^{\prime} 57^{\prime \prime}$ & Durham & $\begin{array}{l}\text { Southeast } \\
\text { Durham }\end{array}$ & 10.1 & Neuse River & 03020201 & 2 & $1972-73$ & 7 & 0 \\
\hline 107 & 02087010 & Little Lick Creek near Redwood & $36^{\circ} 00^{\prime} 57^{\prime \prime}$ & $78^{\circ} 45^{\prime} 38^{\prime \prime}$ & Durham & $\begin{array}{l}\text { Northeast } \\
\text { Durham }\end{array}$ & 19.4 & Neuse River & 03020201 & 2 & $\begin{array}{l}1954,1958,1964-68 \\
1970,1972-73\end{array}$ & 23 & 9 \\
\hline 108 & 02087016 & Ledge Creek above Lake near Creedmoor & $36^{\circ} 08^{\prime} 34^{\prime \prime}$ & $78^{\circ} 42^{\prime} 19^{\prime \prime}$ & Granville & Creedmoor & 6.99 & Neuse River & 03020201 & 2 & 1958 & 1 & 1 \\
\hline 109 & 02087018 & Holman Creek near Creedmoor & $36^{\circ} 08^{\prime} 11^{\prime \prime}$ & $78^{\circ} 41^{\prime} 50^{\prime \prime}$ & Granville & Creedmoor & 7.11 & $\begin{array}{l}\text { Ledge } \\
\quad \text { Creek }\end{array}$ & 03020201 & 2 & 1958,1964 & 2 & 2 \\
\hline 110 & 02087021 & Ledge Creek at Creedmoor & $36^{\circ} 07^{\prime} 45^{\prime \prime}$ & $78^{\circ} 42^{\prime} 20^{\prime \prime}$ & Granville & Creedmoor & 17.5 & Neuse River & 03020201 & 2 & $1974-75$ & 5 & 0 \\
\hline 111 & 0208702110 & Ledge Creek at SR 1110 near Creedmoor & $36^{\circ} 07^{\prime} 00^{\prime \prime}$ & $78^{\circ} 42^{\prime} 30^{\prime \prime}$ & Granville & Creedmoor & $20^{\mathrm{a}}$ & Neuse River & 03020201 & 2 & $1972-73$ & 5 & 0 \\
\hline 112 & 02087024 & $\begin{array}{l}\text { Ledge Creek tributary no. } 2 \text { near } \\
\text { Northside }\end{array}$ & $36^{\circ} 04^{\prime} 32^{\prime \prime}$ & $78^{\circ} 43^{\prime} 17^{\prime \prime}$ & Granville & Creedmoor & 3.86 & $\begin{array}{l}\text { Ledge } \\
\text { Creek }\end{array}$ & 03020201 & 2 & $\begin{array}{l}1958,1961,1964,1968 \\
1970\end{array}$ & 6 & 6 \\
\hline 113 & 02087029 & Lick Creek near Oak Grove & $35^{\circ} 58^{\prime} 06^{\prime \prime}$ & $78^{\circ} 46^{\prime} 10^{\prime \prime}$ & Durham & $\begin{array}{l}\text { Southeast } \\
\text { Durham }\end{array}$ & 8.75 & Neuse River & 03020201 & 2 & 1968 & 1 & 1 \\
\hline 114 & 02087030 & Lick Creek near Durham & $35^{\circ} 58^{\prime} 50^{\prime \prime}$ & $78^{\circ} 44^{\prime} 19^{\prime \prime}$ & Durham & Bayleaf & 13.8 & Neuse River & 03020201 & 2 & $1958,1961-71$ & 14 & 2 \\
\hline 115 & 02087033 & Lick Creek near Rogers Store & $35^{\circ} 59^{\prime} 45^{\prime \prime}$ & $78^{\circ} 43^{\prime} 27^{\prime \prime}$ & Durham & Bayleaf & 16.4 & Neuse River & 03020201 & 2 & $1954,1964,1968$ & 3 & 3 \\
\hline 116 & 02087036 & Laurel Creek near Rogers Store & $35^{\circ} 59^{\prime} 00^{\prime \prime}$ & $78^{\circ} 43^{\prime} 08^{\prime \prime}$ & Durham & Bayleaf & 2.77 & Lick Creek & 03020201 & 2 & $1954,1964,1966,1968$ & 4 & 1 \\
\hline 117 & 02087041 & Beaverdam Creek near Mount Energy & $36^{\circ} 05^{\prime} 26^{\prime \prime}$ & $78^{\circ} 38^{\prime} 23^{\prime \prime}$ & Granville & Creedmoor & 12.7 & Neuse River & 03020201 & 2 & $1958,1964,1968$ & 3 & 3 \\
\hline 118 & 02087046 & $\begin{array}{l}\text { Robertson Creek at NC } 56 \text { near } \\
\text { Creedmoor }\end{array}$ & $36^{\circ} 07^{\prime} 18^{\prime \prime}$ & $78^{\circ} 39^{\prime} 43^{\prime \prime}$ & Granville & Creedmoor & 9.28 & $\begin{array}{l}\text { Beaverdam } \\
\text { Creek }\end{array}$ & 03020201 & 2 & $1954,1958,1968,1970$ & 6 & 5 \\
\hline
\end{tabular}




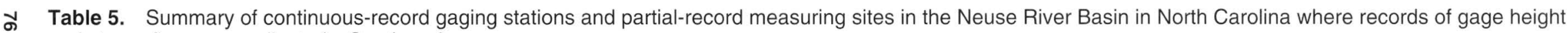
and streamflow were collected-Continued

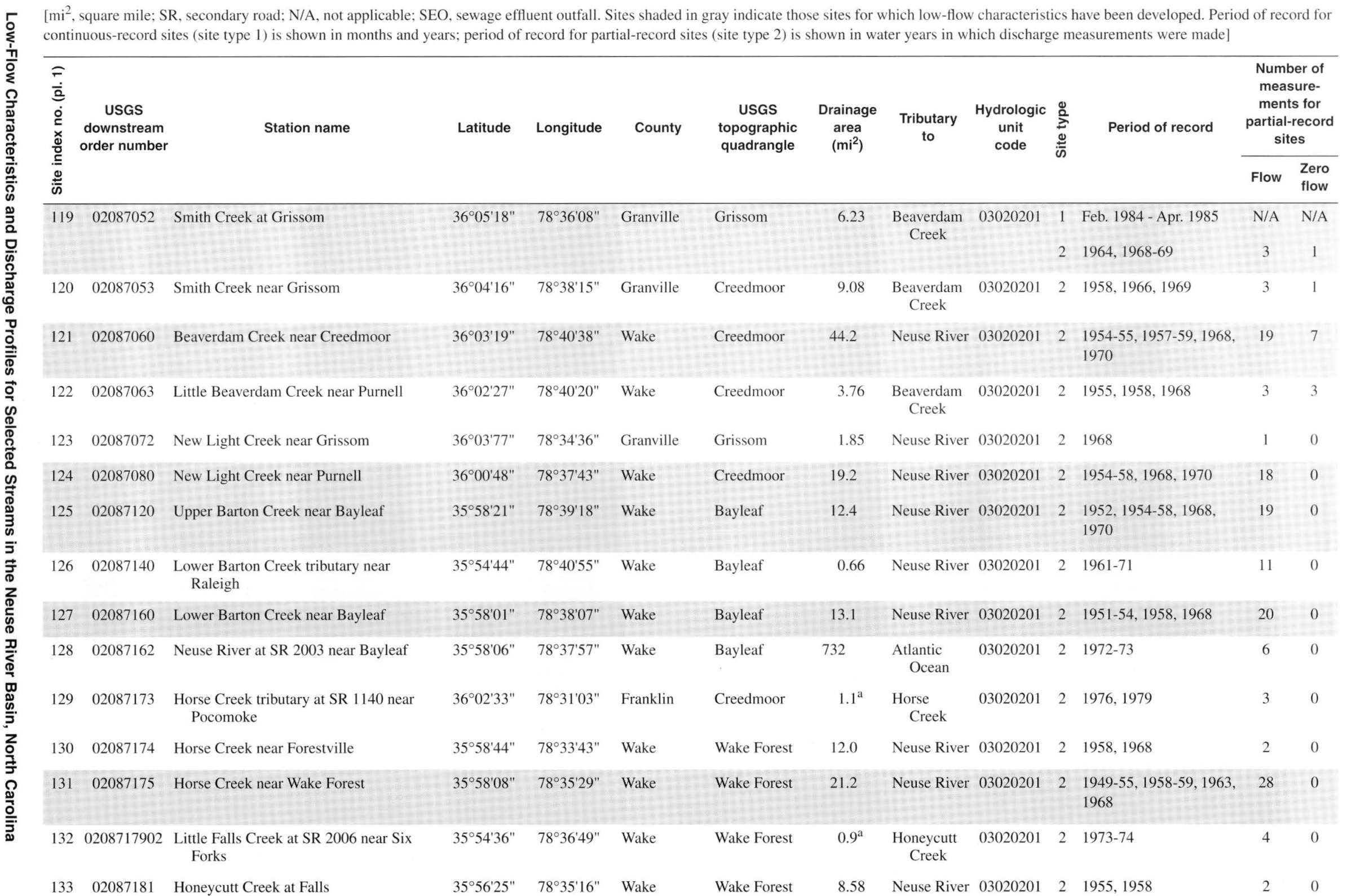


Table 5. Summary of continuous-record gaging stations and partial-record measuring sites in the Neuse River Basin in North Carolina where records of gage height and streamflow were collected-Continued

$\left[\mathrm{mi}^{2}\right.$, square mile; SR, secondary road; N/A, not applicable; SEO, sewage effluent outfall. Sites shaded in gray indicate those sites for which low-flow characteristics have been developed. Period of record for continuous-record sites (site type 1) is shown in months and years; period of record for partial-record sites (site type 2) is shown in water years in which discharge measurements were made]

\begin{tabular}{|c|c|c|c|c|c|c|c|c|c|c|c|c|c|}
\hline \multirow{2}{*}{ 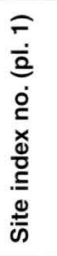 } & \multirow[t]{2}{*}{$\begin{array}{c}\text { USGS } \\
\text { downstream } \\
\text { order number }\end{array}$} & \multirow[t]{2}{*}{ Station name } & \multirow[t]{2}{*}{ Latitude } & \multirow[t]{2}{*}{ Longitude } & \multirow[t]{2}{*}{ County } & \multirow[t]{2}{*}{$\begin{array}{c}\text { USGS } \\
\text { topographic } \\
\text { quadrangle }\end{array}$} & \multirow[t]{2}{*}{$\begin{array}{c}\text { Drainage } \\
\text { area } \\
\left(\mathrm{mi}^{2}\right)\end{array}$} & \multirow[t]{2}{*}{$\begin{array}{l}\text { Tributary } \\
\text { to }\end{array}$} & \multirow[t]{2}{*}{$\begin{array}{c}\text { Hydrologic } \\
\text { unit } \\
\text { code }\end{array}$} & \multirow[t]{2}{*}{$\begin{array}{l}\sum_{0}^{0} \\
\stackrel{0}{0}\end{array}$} & \multirow[t]{2}{*}{ Period of record } & \multicolumn{2}{|c|}{$\begin{array}{l}\text { Number of } \\
\text { measure- } \\
\text { ments for } \\
\text { partial-record } \\
\text { sites }\end{array}$} \\
\hline & & & & & & & & & & & & Flow & $\begin{array}{l}\text { Zero } \\
\text { flow }\end{array}$ \\
\hline 134 & 02087182 & Neuse River at Falls & $35^{\circ} 5627^{\prime \prime}$ & $78^{\circ} 34^{\prime} 57^{\prime \prime}$ & Wake & Wake Forest & 771 & $\begin{array}{l}\text { Atlantic } \\
\text { Ocean }\end{array}$ & 03020201 & 2 & $1968-70$ & 20 & 0 \\
\hline 135 & 02087183 & Neuse River near Falls & $35^{\circ} 56^{\prime} 25^{\prime \prime}$ & $78^{\circ} 34^{\prime} 56^{\prime \prime}$ & Wake & Wake Forest & 771 & $\begin{array}{l}\text { Atlantic } \\
\text { Ocean }\end{array}$ & 03020201 & 1 & July 1970 - Sept. 1996 & N/A & N/A \\
\hline 136 & 0208718385 & Hattels Branch at NC 96 at Youngsville & $36^{\circ} 01^{\prime} 15^{\prime \prime}$ & $78^{\circ} 28^{\prime} 26^{\prime \prime}$ & Franklin & Franklinton & $0.1^{\mathrm{a}}$ & $\begin{array}{c}\text { Richland } \\
\text { Creek }\end{array}$ & 03020201 & 2 & $1972-75$ & 9 & 1 \\
\hline 137 & 0208718440 & $\begin{array}{l}\text { Hattels Branch at U.S. 1A near Youngs- } \\
\text { ville }\end{array}$ & $36^{\circ} 00^{\prime} 55^{\prime \prime}$ & $78^{\circ} 29^{\prime} 29^{\prime \prime}$ & Franklin & Franklinton & 1.35 & $\begin{array}{c}\text { Richland } \\
\text { Creek }\end{array}$ & 03020201 & 2 & $1972-74$ & 8 & 0 \\
\hline 138 & 02087185 & Richland Creek tributary at Wake Forest & $36^{\circ} 00^{\prime} 00^{\prime \prime}$ & $78^{\circ} 30^{\prime} 00^{\prime \prime}$ & Wake & Wake Forest & 0.23 & $\begin{array}{l}\text { Richland } \\
\text { Creek }\end{array}$ & 03020201 & 2 & $1954-55,1968$ & 4 & 0 \\
\hline 139 & 02087186 & Richland Creek at Wake Forest & $35^{\circ} 59^{\prime} 44^{\prime \prime}$ & $78^{\circ} 30^{\prime} 40^{\prime \prime}$ & Wake & Wake Forest & 6.15 & Neuse River & 03020201 & 2 & $1954-55,1968,1970$ & 8 & 0 \\
\hline 140 & 02087187 & Richland Creek at NC 98 at Wake Forest & $35^{\circ} 58^{\prime} 41^{\prime \prime}$ & $78^{\circ} 31^{\prime 2} 28^{\prime \prime}$ & Wake & Wake Forest & 7.66 & Neuse River & 03020201 & 2 & $1972-74$ & 6 & 0 \\
\hline 141 & 02087188 & Richland Creek near Forestville & $35^{\circ} 57^{\prime} 42^{\prime \prime}$ & $78^{\circ} 32^{\prime} 33^{\prime \prime}$ & Wake & Wake Forest & 10.5 & Neuse River & 03020201 & 2 & $1954-55,1968,1972-74$ & 11 & 0 \\
\hline 142 & 02087189 & Richland Creek near Wyatt & $35^{\circ} 560^{\prime \prime}$ & $78^{\circ} 33^{\prime} 10^{\prime \prime}$ & Wake & Wake Forest & 12.6 & Neuse River & 03020201 & 2 & 1955 & 2 & 0 \\
\hline 143 & 0208718995 & $\begin{array}{l}\text { Neuse River above U.S. Hwy } 1 \text { near } \\
\text { Neuse }\end{array}$ & $35^{\circ} 54^{\prime} 36^{\prime \prime}$ & $78^{\circ} 33^{\prime} 27^{\prime \prime}$ & Wake & Wake Forest & $790^{\mathrm{a}}$ & $\begin{array}{l}\text { Atlantic } \\
\text { Ocean }\end{array}$ & 03020201 & 2 & $1972-73,1975$ & 3 & 0 \\
\hline 144 & 02087190 & Neuse River at U.S. Hwy 1 near Neuse & $35^{\circ} 54^{\prime} 32^{\prime \prime}$ & $78^{\circ} 33^{\prime} 18^{\prime \prime}$ & Wake & Wake Forest & 792 & $\begin{array}{l}\text { Atlantic } \\
\text { Ocean }\end{array}$ & 03020201 & 1 & $\begin{array}{l}\text { Oct. } 1959 \text { - Sept. } 1971 \\
\text { (medium/high flows } \\
\text { only prior to Oct. 1969) }\end{array}$ & N/A & N/A \\
\hline & & & & & & & & & & 2 & $1954-55,1968$ & 5 & 0 \\
\hline 145 & 02087193 & Smith Creek at Wake Forest & $35^{\circ} 58^{\prime} 09^{\prime \prime}$ & $78^{\circ} 29^{\prime} 20^{\prime \prime}$ & Wake & Rolesville & 3.38 & Neuse River & 03020201 & 2 & $1959,1968,1974-75$ & 7 & 0 \\
\hline 146 & 02087194 & Austin Creek at Wake Forest & $35^{\circ} 57^{\prime} 41^{\prime \prime}$ & $78^{\circ} 29^{\prime} 12^{\prime \prime}$ & Wake & Rolesville & 3.98 & $\begin{array}{l}\text { Smith } \\
\text { Creek }\end{array}$ & 03020201 & 2 & $1958-59,1968$ & 3 & 0 \\
\hline 147 & 02087196 & Hatters Branch at Wake Forest & $35^{\circ} 58^{\prime} 21^{\prime \prime}$ & $78^{\circ} 29^{\prime} 44^{\prime \prime}$ & Wake & Rolesville & 1.82 & $\begin{array}{l}\text { Smith } \\
\text { Creek }\end{array}$ & 03020201 & 2 & 1959,1968 & 2 & 0 \\
\hline 148 & 02087203 & Smith Creek at Forestville & $35^{\circ} 56^{\prime} 55^{\prime \prime}$ & $78^{\circ} 30^{\prime} 32^{\prime \prime}$ & Wake & Wake Forest & 12.8 & Neuse River & 03020201 & 2 & $1972-74$ & 6 & 0 \\
\hline
\end{tabular}




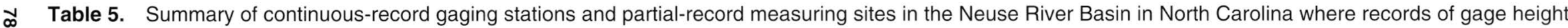
and streamflow were collected-Continued

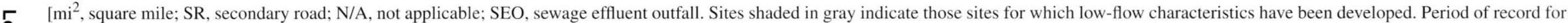
continuous-record sites (site type 1) is shown in months and years; period of record for partial-record sites (site type 2) is shown in water years in which discharge measurements were made]

\begin{tabular}{|c|c|c|c|c|c|c|c|c|c|c|c|c|c|}
\hline \multirow{2}{*}{ 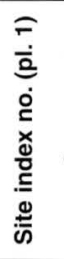 } & \multirow[t]{2}{*}{$\begin{array}{c}\text { USGS } \\
\text { downstream } \\
\text { order number }\end{array}$} & \multirow[t]{2}{*}{ Station name } & \multirow[t]{2}{*}{ Latitude } & \multirow[t]{2}{*}{ Longitude } & \multirow[t]{2}{*}{ County } & \multirow[t]{2}{*}{$\begin{array}{c}\text { USGS } \\
\text { topographic } \\
\text { quadrangle }\end{array}$} & \multirow[t]{2}{*}{$\begin{array}{c}\text { Drainage } \\
\text { area } \\
\left(\mathrm{mi}^{2}\right)\end{array}$} & \multirow[t]{2}{*}{$\begin{array}{l}\text { Tributary } \\
\text { to }\end{array}$} & \multirow[t]{2}{*}{$\begin{array}{l}\text { Hydrologic } \\
\text { unit } \\
\text { code }\end{array}$} & \multirow[t]{2}{*}{$\frac{\sum_{0}^{\circ}}{\stackrel{\vdots}{\vdots}}$} & \multirow[t]{2}{*}{ Period of record } & \multicolumn{2}{|c|}{$\begin{array}{c}\text { Number of } \\
\text { measure- } \\
\text { ments for } \\
\text { partial-record } \\
\text { sites }\end{array}$} \\
\hline & & & & & & & & & & & & Flow & $\begin{array}{l}\text { Zero } \\
\text { flow }\end{array}$ \\
\hline 149 & 0208720330 & Smith Creek at SR 2044 near Forestville & $35^{\circ} 55^{\prime} 44^{\prime \prime}$ & $78^{\circ} 31^{\prime} 40^{\prime \prime}$ & Wake & Wake Forest & $21^{\mathrm{a}}$ & Neuse River & 03020201 & 2 & $1972-74$ & 5 & 0 \\
\hline 150 & 02087204 & Smith Creek near Rolesville & $35^{\circ} 55^{\prime} 10^{\prime \prime}$ & $78^{\circ} 32^{\prime} 04^{\prime \prime}$ & Wake & Wake Forest & 22.6 & Neuse River & 03020201 & 2 & $1954-55,1968,1970$ & 6 & 0 \\
\hline 151 & 02087206 & Mill Creek near Wake Crossroads & $35^{\circ} 54^{\prime} 22^{\prime \prime}$ & $78^{\circ} 31^{\prime} 36^{\prime \prime}$ & Wake & Wake Forest & 1.12 & Neuse River & 03020201 & 2 & 1955,1968 & 2 & 0 \\
\hline 152 & 02087208 & Toms Creek near Wake Crossroads & $35^{\circ} 54^{\prime} 21^{\prime \prime}$ & $78^{\circ} 32^{\prime} 39^{\prime \prime}$ & Wake & Wake Forest & 3.39 & Mill Creek & 03020201 & 2 & 1955,1968 & 2 & 0 \\
\hline 153 & 0208721055 & Perry Creek at SR 2012 near Millbrook & $35^{\circ} 52^{\prime} 30^{\prime \prime}$ & $78^{\circ} 35^{\prime} 48^{\prime \prime}$ & Wake & Raleigh East & 2.43 & Neuse River & 03020201 & 1 & Mar. 1986 - Sept. 1989 & N/A & N/A \\
\hline 154 & 0208721290 & Perry Creek tributary at Neuse & $35^{\circ} 53^{\prime} 47^{\prime \prime}$ & $78^{\circ} 34^{\prime} 46^{\prime \prime}$ & Wake & Raleigh East & 1.07 & Perry Creek & 03020201 & 1 & Oct. 1985 - Sept. 1988 & N/A & N/A \\
\hline 155 & 02087216 & Neuse River at Wake Crossroads & $35^{\circ} 53^{\prime} 02^{\prime \prime}$ & $78^{\circ} 31^{\prime} 43^{\prime \prime}$ & Wake & Wake Forest & 835 & $\begin{array}{l}\text { Atlantic } \\
\text { Ocean }\end{array}$ & 03020201 & 2 & 1972 & 1 & 0 \\
\hline 156 & 02087217 & Hodges Mill Creek near Rolesville & $35^{\circ} 51^{\prime} 06^{\prime \prime}$ & $78^{\circ} 29^{\prime} 17^{\prime \prime}$ & Wake & Knightdale & 5.33 & Neuse River & 03020201 & 2 & 1955 & 1 & 0 \\
\hline 157 & 02087218 & Hodges Mill Creek near Knightdale & $35^{\circ} 51^{\prime} 16^{\prime \prime}$ & $78^{\circ} 29^{\prime} 54^{\prime \prime}$ & Wake & Knightdale & 6.17 & Neuse River & 03020201 & 2 & 1967 & 1 & 0 \\
\hline 158 & 02087219 & Hodges Mill Creek near Milburnie & $35^{\circ} 51^{\prime} 22^{\prime \prime}$ & $78^{\circ} 30^{\prime} 46^{\prime \prime}$ & Wake & Raleigh East & 7.92 & Neuse River & 03020201 & 2 & 1955 & 1 & 0 \\
\hline 159 & 02087220 & Harris Creek near Wake Crossroads & $35^{\circ} 51^{\prime} 53^{\prime \prime}$ & $78^{\circ} 30^{\prime} 53^{\prime \prime}$ & Wake & Raleigh East & 9.85 & $\begin{array}{l}\text { Hodges } \\
\text { Mill } \\
\text { Creek }\end{array}$ & 03020201 & 2 & $1954-59,1961-64$ & 22 & 0 \\
\hline 160 & 02087224 & Neuse River at Buffalo Road near Raleigh & $35^{\circ} 50^{\prime} 53^{\prime \prime}$ & $78^{\circ} 31^{\prime} 49^{\prime \prime}$ & Wake & Raleigh East & 859 & $\begin{array}{l}\text { Atlantic } \\
\text { Ocean }\end{array}$ & 03020201 & 2 & $1972-73$ & 5 & 0 \\
\hline 161 & 02087226 & Beaverdam Creek near Knightdale & $35^{\circ} 49^{\prime} 03^{\prime \prime}$ & $78^{\circ} 30^{\prime} 11^{\prime \prime}$ & Wake & Raleigh East & 3.43 & Neuse River & 03020201 & 2 & 1955 & 1 & 0 \\
\hline 162 & 02087229 & Neuse River near Raleigh & $35^{\circ} 47^{\prime} 35^{\prime \prime}$ & $78^{\circ} 32^{\prime} 21^{\prime \prime}$ & Wake & Raleigh East & 877 & $\begin{array}{l}\text { Atlantic } \\
\text { Ocean }\end{array}$ & 03020201 & 2 & $\begin{array}{l}\text { 1927, 1954-55, 1974, } \\
1997\end{array}$ & 10 & 0 \\
\hline 163 & 0208723010 & Mango Creek at SR 2516 near Knightdale & $35^{\circ} 46^{\prime} 37^{\prime \prime}$ & $78^{\circ} 31^{\prime} 32^{\prime \prime}$ & Wake & Raleigh East & $3.6^{\mathrm{a}}$ & Neuse River & 03020201 & 2 & $1973-75$ & 7 & 1 \\
\hline 164 & 0208723280 & Crabtree Creek at SR 1615 near Cary & $35^{\circ} 47^{\prime} 26^{\prime \prime}$ & $78^{\circ} 49^{\prime} 56^{\prime \prime}$ & Wake & Cary & 3.83 & Neuse River & 03020201 & 2 & 1973-74 & 6 & 2 \\
\hline 165 & 0208723397 & $\begin{array}{l}\text { Coles Branch } 2.4 \text { miles from mouth at } \\
\text { Cary }\end{array}$ & $35^{\circ} 47^{\prime} 30^{\prime \prime}$ & $78^{\circ} 47^{\prime} 37^{\prime \prime}$ & Wake & Cary & $0.1^{\mathrm{a}}$ & $\begin{array}{r}\text { Crabtree } \\
\text { Creek }\end{array}$ & 03020201 & 2 & 1973-75 & 8 & 2 \\
\hline
\end{tabular}


Table 5. Summary of continuous-record gaging stations and partial-record measuring sites in the Neuse River Basin in North Carolina where records of gage height and streamflow were collected-Continued

$\left[\mathrm{mi}^{2}\right.$, square mile; SR, secondary road; N/A, not applicable; SEO, sewage effluent outfall. Sites shaded in gray indicate those sites for which low-flow characteristics have been developed. Period of record for continuous-record sites (site type 1) is shown in months and years; period of record for partial-record sites (site type 2) is shown in water years in which discharge measurements were made]

\begin{tabular}{|c|c|c|c|c|c|c|c|c|c|c|c|c|c|}
\hline \multirow{2}{*}{ 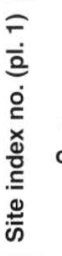 } & \multirow{2}{*}{$\begin{array}{c}\text { USGS } \\
\text { downstream } \\
\text { order number }\end{array}$} & \multirow[t]{2}{*}{ Station name } & \multirow[t]{2}{*}{ Latitude } & \multirow[t]{2}{*}{ Longitude } & \multirow[t]{2}{*}{ County } & \multirow[t]{2}{*}{$\begin{array}{c}\text { USGS } \\
\text { topographic } \\
\text { quadrangle }\end{array}$} & \multirow[t]{2}{*}{$\begin{array}{l}\text { Drainage } \\
\text { area } \\
\left(\mathrm{mi}^{2}\right)\end{array}$} & \multirow[t]{2}{*}{$\begin{array}{l}\text { Tributary } \\
\text { to }\end{array}$} & \multirow[t]{2}{*}{$\begin{array}{l}\text { Hydrologic } \\
\text { unit } \\
\text { code }\end{array}$} & \multirow[t]{2}{*}{ 竞 } & \multirow[t]{2}{*}{ Period of record } & \multicolumn{2}{|c|}{$\begin{array}{c}\text { Number of } \\
\text { measure- } \\
\text { ments for } \\
\text { partial-record } \\
\text { sites }\end{array}$} \\
\hline & & & & & & & & & & & & Flow & $\begin{array}{l}\text { Zero } \\
\text { flow }\end{array}$ \\
\hline 166 & 0208723425 & Coles Branch near Cary & $35^{\circ} 47^{\prime} 29^{\prime \prime}$ & $78^{\circ} 48^{\prime} 23^{\prime \prime}$ & Wake & Cary & $1.2^{\mathrm{a}}$ & $\begin{array}{r}\text { Crabtree } \\
\text { Creek }\end{array}$ & 03020201 & 2 & $1974-75$ & 6 & 0 \\
\hline 167 & 0208723560 & Crabtree Creek tributary at Morrisville & $35^{\circ} 49^{\prime} 30^{\prime \prime}$ & $78^{\circ} 48^{\prime} 46^{\prime \prime}$ & Wake & Cary & $0.9^{\mathrm{a}}$ & $\begin{array}{r}\text { Crabtree } \\
\text { Creek }\end{array}$ & 03020201 & 2 & 1972 & 1 & 0 \\
\hline 168 & 02087236 & Crabtree Creek at Morrisville & $35^{\circ} 49^{\prime} 15^{\prime \prime}$ & $78^{\circ} 49^{\prime} 27^{\prime \prime}$ & Wake & Cary & 14.7 & Neuse River & 03020201 & 2 & $\begin{array}{l}1932,1961-62,1968 \\
1972-74\end{array}$ & 10 & 4 \\
\hline 169 & 0208723750 & Licks Creek near Morrisville & $35^{\circ} 50^{\prime} 45^{\prime \prime}$ & $78^{\circ} 49^{\prime} 49^{\prime \prime}$ & Wake & Cary & $0.3^{\mathrm{a}}$ & $\begin{array}{r}\text { Crabtree } \\
\text { Creek }\end{array}$ & 03020201 & 2 & $1972-75$ & 8 & 4 \\
\hline 170 & 0208723757 & Licks Creek at Morrisville & $35^{\circ} 49^{\prime} 55^{\prime \prime}$ & $78^{\circ} 48^{\prime} 57^{\prime \prime}$ & Wake & Cary & $0.9^{\mathrm{a}}$ & $\begin{array}{r}\text { Crabtree } \\
\text { Creek }\end{array}$ & 03020201 & 2 & $1973-75$ & 7 & 3 \\
\hline 171 & 02087238 & Stirrup Iron Creek at Nelson & $35^{\circ} 52^{\prime} 57^{\prime \prime}$ & $78^{\circ} 50^{\prime} 10^{\prime \prime}$ & Durham & $\begin{array}{l}\text { Southeast } \\
\text { Durham }\end{array}$ & 7.09 & $\begin{array}{r}\text { Crabtree } \\
\text { Creek }\end{array}$ & 03020201 & 2 & $1958,1962,1966,1968$ & 4 & 4 \\
\hline 172 & 02087240 & Stirrup Iron Creek tributary near Nelson & $35^{\circ} 53^{\prime} 06^{\prime \prime}$ & $78^{\circ} 49^{\prime} 37^{\prime \prime}$ & Durham & Durham South & 0.25 & $\begin{array}{l}\text { Stirrup Iron } \\
\text { Creek }\end{array}$ & 03020201 & 2 & $1961-73$ & 20 & 0 \\
\hline 173 & 02087241 & Stirrup Iron Creek near Nelson & $35^{\circ} 51^{\prime} 35^{\prime \prime}$ & $78^{\circ} 49^{\prime} 05^{\prime \prime}$ & Wake & Cary & 9.22 & $\begin{array}{r}\text { Crabtree } \\
\text { Creek }\end{array}$ & 03020201 & 2 & 1962,1968 & 2 & 1 \\
\hline 174 & 0208724350 & $\begin{array}{l}\text { Little Brier Creek tributary at U.S. } 70 \text { near } \\
\text { Leesville }\end{array}$ & $35^{\circ} 54^{\prime} 36^{\prime \prime}$ & $78^{\circ} 46^{\prime} 45^{\prime \prime}$ & Wake & $\begin{array}{l}\text { Southeast } \\
\text { Durham }\end{array}$ & 1.15 & $\begin{array}{l}\text { Little Brier } \\
\text { Creek }\end{array}$ & 03020201 & 2 & $1974-75$ & 6 & 1 \\
\hline 175 & 0208724375 & $\begin{array}{l}\text { Little Brier tributary at SR } 1645 \text { near } \\
\text { Leesville }\end{array}$ & $35^{\circ} 54^{\prime} 00^{\prime \prime}$ & $78^{\circ} 47^{\prime} 15^{\prime \prime}$ & Wake & Durham South & $2.2^{\mathrm{a}}$ & $\begin{array}{l}\text { Little Brier } \\
\text { Creek }\end{array}$ & 03020201 & 2 & $1974-75$ & 7 & 2 \\
\hline 176 & 02087246 & Little Brier Creek near Nelson & $35^{\circ} 52^{\prime} 55^{\prime \prime}$ & $78^{\circ} 48^{\prime} 07^{\prime \prime}$ & Wake & $\begin{array}{l}\text { Southeast } \\
\text { Durham }\end{array}$ & 8.58 & Brier Creek & 03020201 & 2 & $1955,1962,1968,1970$ & 6 & 4 \\
\hline 177 & 02087249 & Stirrup Iron Creek near Morrisville & $35^{\circ} 50^{\prime} 34^{\prime \prime}$ & $78^{\circ} 48^{\prime} 15^{\prime \prime}$ & Wake & Cary & 25.4 & $\begin{array}{r}\text { Crabtree } \\
\text { Creek }\end{array}$ & 03020201 & 2 & $1961-62,1968,1972-74$ & 10 & 3 \\
\hline 178 & 02087251 & Crabtree Creek near Cary & $35^{\circ} 50^{\prime} 15^{\prime \prime}$ & $78^{\circ} 462^{\prime \prime}$ & Wake & Cary & 52.2 & Neuse River & 03020201 & 2 & $\begin{array}{l}1961-62,1968,1982-92 \\
1995-96\end{array}$ & 50 & 0 \\
\hline 179 & 0208725110 & Crabtree Creek at I-40 near Cary & $35^{\circ} 50^{\prime} 19^{\prime \prime}$ & $78^{\circ} 46^{\prime} 49^{\prime \prime}$ & Wake & Cary & $52^{\mathrm{a}}$ & Neuse River & 03020201 & 2 & 1973 & 4 & 0 \\
\hline 180 & 0208725115 & Crabtree Creek near Tysonville & $35^{\circ} 50^{\prime} 29^{\prime \prime}$ & $78^{\circ} 44^{\prime} 40^{\prime \prime}$ & Wake & Raleigh West & 54.8 & Neuse River & 03020201 & 2 & 1984 & 1 & 0 \\
\hline
\end{tabular}




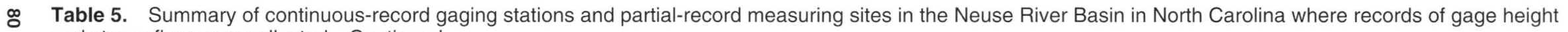
and streamflow were collected-Continued

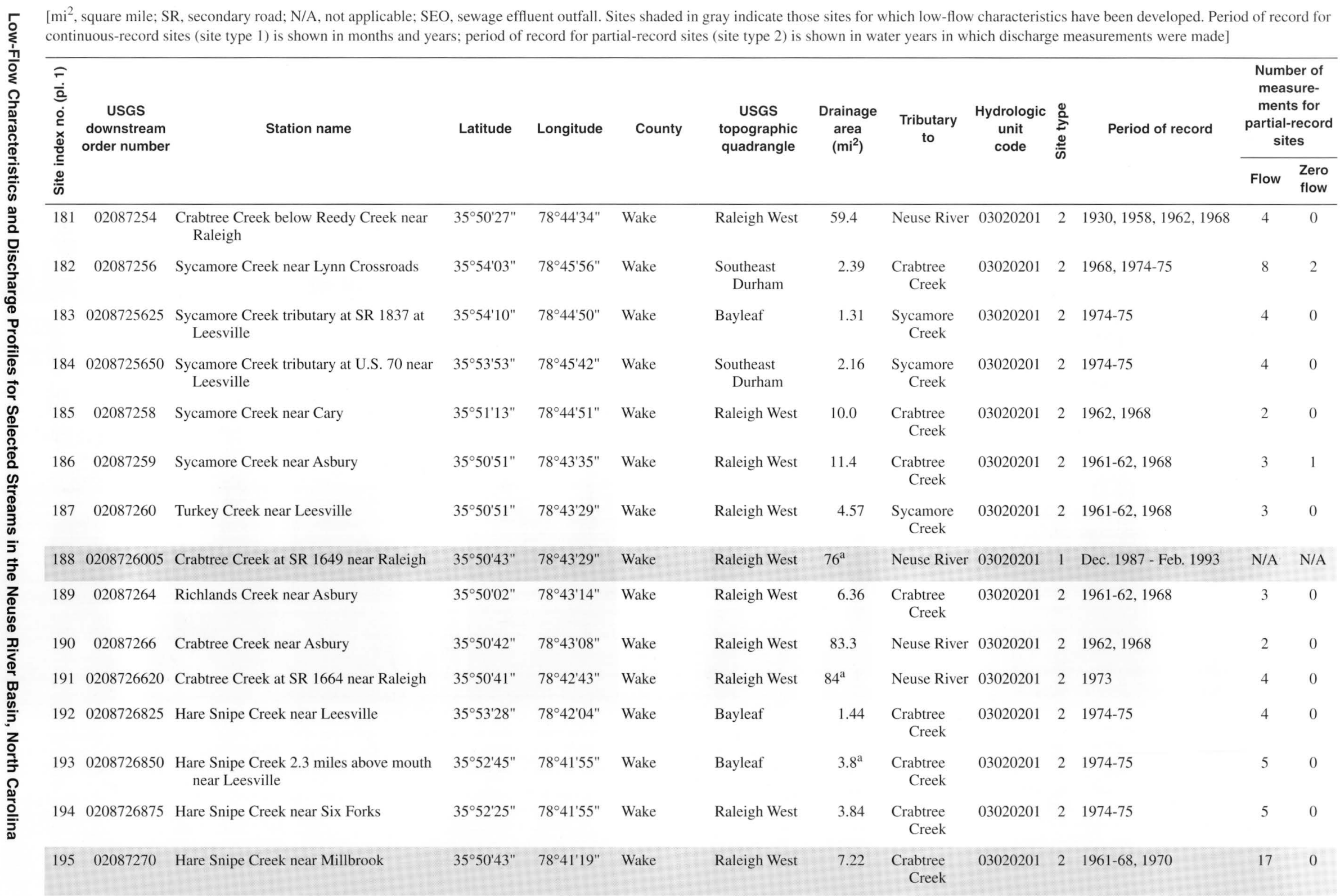


Table 5. Summary of continuous-record gaging stations and partial-record measuring sites in the Neuse River Basin in North Carolina where records of gage height and streamflow were collected-Continued

$\left[\mathrm{mi}^{2}\right.$, square mile; SR, secondary road; N/A, not applicable; SEO, sewage effluent outfall. Sites shaded in gray indicate those sites for which low-flow characteristics have been developed. Period of record for continuous-record sites (site type 1) is shown in months and years; period of record for partial-record sites (site type 2) is shown in water years in which discharge measurements were made]

\begin{tabular}{|c|c|c|c|c|c|c|c|c|c|c|c|c|c|}
\hline \multirow{2}{*}{ 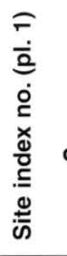 } & \multirow[t]{2}{*}{$\begin{array}{c}\text { USGS } \\
\text { downstream } \\
\text { order number }\end{array}$} & \multirow[t]{2}{*}{ Station name } & \multirow[t]{2}{*}{ Latitude } & \multirow[t]{2}{*}{ Longitude } & \multirow[t]{2}{*}{ County } & \multirow[t]{2}{*}{$\begin{array}{c}\text { USGS } \\
\text { topographic } \\
\text { quadrangle }\end{array}$} & \multirow[t]{2}{*}{$\begin{array}{l}\text { Drainage } \\
\text { area } \\
\left(\mathrm{mi}^{2}\right)\end{array}$} & \multirow[t]{2}{*}{$\begin{array}{l}\text { Tributary } \\
\text { to }\end{array}$} & \multirow[t]{2}{*}{$\begin{array}{l}\text { Hydrologic } \\
\text { unit } \\
\text { code }\end{array}$} & \multirow[t]{2}{*}{ 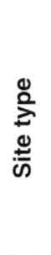 } & \multirow[t]{2}{*}{ Period of record } & \multicolumn{2}{|c|}{$\begin{array}{c}\text { Number of } \\
\text { measure- } \\
\text { ments for } \\
\text { partial-record } \\
\text { sites }\end{array}$} \\
\hline & & & & & & & & & & & & Flow & $\begin{array}{l}\text { Zero } \\
\text { flow }\end{array}$ \\
\hline 196 & 02087273 & House Creek near Raleigh & $35^{\circ} 49^{\prime} 23^{\prime \prime}$ & $78^{\circ} 41^{\prime} 06^{\prime \prime}$ & Wake & Raleigh West & 2.20 & $\begin{array}{r}\text { Crabtree } \\
\text { Creek }\end{array}$ & 03020201 & 2 & 1963 & 1 & 0 \\
\hline 197 & 02087274 & House Creek near Method & $35^{\circ} 50^{\prime} 06^{\prime \prime}$ & $78^{\circ} 40^{\prime} 30^{\prime \prime}$ & Wake & Raleigh West & 2.89 & $\begin{array}{r}\text { Crabtree } \\
\text { Creek }\end{array}$ & 03020201 & 2 & $1961-62,1968$ & 3 & 0 \\
\hline 198 & 0208727450 & Crabtree Creek at SR 1670 near Raleigh & $35^{\circ} 50^{\prime} 11^{\prime \prime}$ & $78^{\circ} 40^{\prime} 31^{\prime \prime}$ & Wake & Raleigh West & $97^{\mathrm{a}}$ & Neuse River & 03020201 & 2 & 1973 & 1 & 0 \\
\hline 199 & 02087275 & Crabtree Creek at U.S. Hwy 70 at Raleigh & $35^{\circ} 50^{\prime} 15^{\prime \prime}$ & $78^{\circ} 40^{\prime} 26^{\prime \prime}$ & Wake & Raleigh West & 97.6 & Neuse River & 03020201 & 2 & $\begin{array}{l}1932,1942,1947,1949- \\
50,1952-56,1958 \\
1960-63,1968,1973 \\
1978,1997\end{array}$ & 44 & 0 \\
\hline 200 & 02087290 & Mine Creek near Millbrook & $35^{\circ} 51^{\prime} 19^{\prime \prime}$ & $78^{\circ} 39^{\prime} 43^{\prime \prime}$ & Wake & Raleigh West & 8.87 & $\begin{array}{r}\text { Crabtree } \\
\text { Creek }\end{array}$ & 03020201 & 2 & $\begin{array}{l}1951-55,1958,1961-62, \\
1968\end{array}$ & 17 & 0 \\
\hline 201 & 02087296 & Crabtree Creek at Lassiters Mill at Raleigh & $35^{\circ} 49^{\prime} 41^{\prime \prime}$ & $78^{\circ} 39^{\prime} 03^{\prime \prime}$ & Wake & Raleigh West & 110 & Neuse River & 03020201 & 2 & $1961-62$ & 2 & 0 \\
\hline 202 & 0208729610 & $\begin{array}{l}\text { Crabtree Creek at Lassiter Mill Road near } \\
\text { Raleigh }\end{array}$ & $35^{\circ} 49^{\prime} 41^{\prime \prime}$ & $78^{\circ} 39^{\prime} 03^{\prime \prime}$ & Wake & Raleigh West & $110^{\mathrm{a}}$ & Neuse River & 03020201 & 2 & 1973,1997 & 6 & 0 \\
\hline 203 & 02087304 & $\begin{array}{l}\text { Southwest Prong Beaverdam Creek at } \\
\text { Raleigh }\end{array}$ & $35^{\circ} 48^{\prime} 56^{\prime \prime}$ & $78^{\circ} 39^{\prime} 41^{\prime \prime}$ & Wake & Raleigh West & 1.86 & $\begin{array}{l}\text { Beaverdam } \\
\text { Creek }\end{array}$ & 03020201 & 2 & 1963 & 1 & 0 \\
\hline 204 & 02087307 & $\begin{array}{l}\text { Southeast Prong Beaverdam Creek at } \\
\text { Raleigh }\end{array}$ & $35^{\circ} 48^{\prime} 56^{\prime \prime}$ & $78^{\circ} 39^{\prime} 41^{\prime \prime}$ & Wake & Raleigh West & 1.18 & $\begin{array}{l}\text { Beaverdam } \\
\text { Creek }\end{array}$ & 03020201 & 2 & 1963 & 1 & 0 \\
\hline 205 & 02087308 & Beaverdam Creek at Raleigh & $35^{\circ} 49^{\prime} 28^{\prime \prime}$ & $78^{\circ} 39^{\prime} 00^{\prime \prime}$ & Wake & Raleigh West & 3.63 & $\begin{array}{r}\text { Crabtree } \\
\text { Creek }\end{array}$ & 03020201 & 2 & $1961-62$ & 2 & 0 \\
\hline 206 & 0208731190 & $\begin{array}{l}\text { Crabtree Creek at Anderson Drive at } \\
\text { Raleigh }\end{array}$ & $35^{\circ} 49^{\prime} 16^{\prime \prime}$ & $78^{\circ} 37^{\prime} 34^{\prime \prime}$ & Wake & Raleigh West & 111 & Neuse River & 03020201 & 2 & 1997 & 1 & 0 \\
\hline 207 & 02087318 & Big Branch at Millbrook & $35^{\circ} 51^{\prime} 04^{\prime \prime}$ & $78^{\circ} 37^{\prime} 22^{\prime \prime}$ & Wake & Raleigh East & 1.13 & $\begin{array}{r}\text { Crabtree } \\
\text { Creek }\end{array}$ & 03020201 & 2 & 1951,1968 & 2 & 0 \\
\hline 208 & 02087319 & Big Branch near Raleigh & $35^{\circ} 49^{\prime} 59^{\prime \prime}$ & $78^{\circ} 37^{\prime} 36^{\prime \prime}$ & Wake & Raleigh West & 2.19 & $\begin{array}{r}\text { Crabtree } \\
\text { Creek }\end{array}$ & 03020201 & 2 & 1967 & 1 & 0 \\
\hline 209 & 02087320 & Big Branch near Millbrook & $35^{\circ} 49^{\prime} 17^{\prime \prime}$ & $78^{\circ} 37^{\prime} 46^{\prime \prime}$ & Wake & Raleigh West & 3.78 & $\begin{array}{r}\text { Crabtree } \\
\text { Creek }\end{array}$ & 03020201 & 2 & $\begin{array}{l}1951-55,1958,1961-62, \\
1968\end{array}$ & 17 & 0 \\
\hline
\end{tabular}




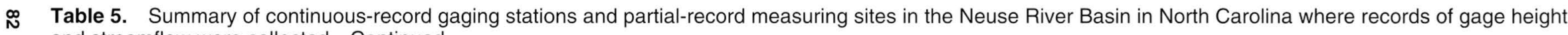
and streamflow were collected-Continued

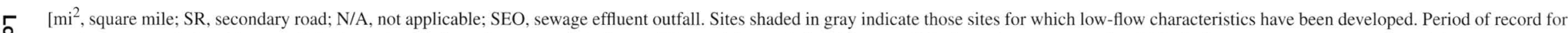
continuous-record sites (site type 1) is shown in months and years; period of record for partial-record sites (site type 2) is shown in water years in which discharge measurements were made]

\begin{tabular}{|c|c|c|c|c|c|c|c|c|c|c|c|c|c|}
\hline \multirow{2}{*}{ 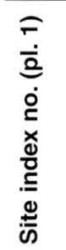 } & \multirow[t]{2}{*}{$\begin{array}{c}\text { USGS } \\
\text { downstream } \\
\text { order number }\end{array}$} & \multirow[t]{2}{*}{ Station name } & \multirow[t]{2}{*}{ Latitude } & \multirow[t]{2}{*}{ Longitude } & \multirow[t]{2}{*}{ County } & \multirow[t]{2}{*}{$\begin{array}{c}\text { USGS } \\
\text { topographic } \\
\text { quadrangle }\end{array}$} & \multirow[t]{2}{*}{$\begin{array}{c}\text { Drainage } \\
\text { area } \\
\left(\mathrm{mi}^{2}\right)\end{array}$} & \multirow[t]{2}{*}{$\begin{array}{l}\text { Tributary } \\
\text { to }\end{array}$} & \multirow[t]{2}{*}{$\begin{array}{l}\text { Hydrologic } \\
\text { unit } \\
\text { code }\end{array}$} & \multirow[t]{2}{*}{$\begin{array}{l}\stackrel{ \pm}{2} \\
\stackrel{ \pm}{\infty}\end{array}$} & \multirow[t]{2}{*}{ Period of record } & \multicolumn{2}{|c|}{$\begin{array}{l}\text { Number of } \\
\text { measure- } \\
\text { ments for } \\
\text { partial-record } \\
\text { sites }\end{array}$} \\
\hline & & & & & & & & & & & & Flow & $\begin{array}{l}\text { Zero } \\
\text { flow }\end{array}$ \\
\hline \multirow[t]{2}{*}{210} & 02087322 & Crabtree Creek at SR 2030 near Raleigh & $35^{\circ} 48^{\prime} 57^{\prime \prime}$ & $78^{\circ} 37^{\prime} 33^{\prime \prime}$ & Wake & Raleigh West & 119 & Neuse River & 03020201 & 1 & Feb. 1988 - Sept. 1989 & N/A & N/A \\
\hline & & & & & & & & & & 2 & $1961-62,1973,1997$ & 7 & 0 \\
\hline 211 & 02087323 & $\begin{array}{l}\text { Crabtree Creek at Old Farmers Market at } \\
\text { Raleigh }\end{array}$ & $35^{\circ} 48^{\prime} 47^{\prime \prime}$ & $78^{\circ} 37^{\prime} 05^{\prime \prime}$ & Wake & Raleigh East & 120 & Neuse River & 03020201 & 2 & $1984-89$ & 30 & 0 \\
\hline \multirow[t]{2}{*}{212} & 02087324 & Crabtree Creek at U.S. 1 at Raleigh & $35^{\circ} 48^{\prime} 40^{\prime \prime}$ & $78^{\circ} 36^{\prime} 43^{\prime \prime}$ & Wake & Raleigh East & 121 & Neuse River & 03020201 & 1 & July 1990 - Sept. 1996 & N/A & N/A \\
\hline & & & & & & & & & & 2 & 1973-75 & 7 & 0 \\
\hline 213 & 0208732544 & Pigeon House Branch at Raleigh & $35^{\circ} 47^{\prime} 37^{\prime \prime}$ & $78^{\circ} 38^{\prime} 35^{\prime \prime}$ & Wake & Raleigh West & 0.59 & $\begin{array}{r}\text { Crabtree } \\
\text { Creek }\end{array}$ & 03020201 & 2 & 1984-92, 1994-96 & 48 & 0 \\
\hline 214 & 02087326 & $\begin{array}{l}\text { Pigeon House Branch at U.S. Hwy } 1 \text { at } \\
\text { Raleigh }\end{array}$ & $35^{\circ} 48^{\prime} 17^{\prime \prime}$ & $78^{\circ} 37^{\prime} 03^{\prime \prime}$ & Wake & Raleigh East & 4.25 & $\begin{array}{r}\text { Crabtree } \\
\text { Creek }\end{array}$ & 03020201 & 2 & $1961-62$ & 2 & 0 \\
\hline 215 & 02087327 & Marsh Creek tributary No. 1 near Raleigh & $35^{\circ} 49^{\prime} 36^{\prime \prime}$ & $78^{\circ} 34^{\prime} 48^{\prime \prime}$ & Wake & Raleigh East & 0.39 & $\begin{array}{l}\text { Marsh } \\
\text { Creek }\end{array}$ & 03020201 & 2 & 1967 & 1 & 0 \\
\hline 216 & 0208732810 & Marsh Creek at SR 2030 at Millbrook & $35^{\circ} 51^{\prime} 13^{\prime \prime}$ & $78^{\circ} 36^{\prime} 12^{\prime \prime}$ & Wake & Raleigh East & 1.44 & $\begin{array}{r}\text { Crabtree } \\
\text { Creek }\end{array}$ & 03020201 & 1 & Mar. 1986 - Sept. 1989 & N/A & N/A \\
\hline 217 & 0208732850 & Marsh Creek tributary at New Hope & $35^{\circ} 50^{\prime} 42^{\prime \prime}$ & $78^{\circ} 35^{\prime} 05^{\prime \prime}$ & Wake & Raleigh East & $0.2^{\mathrm{a}}$ & $\begin{array}{l}\text { Marsh } \\
\text { Creek }\end{array}$ & 03020201 & 2 & 1972 & 1 & 1 \\
\hline 218 & 0208732855 & Marsh Creek tributary near Millbrook & $35^{\circ} 50^{\prime} 10^{\prime \prime}$ & $78^{\circ} 35^{\prime} 20^{\prime \prime}$ & Wake & Raleigh East & $0.5^{\mathrm{a}}$ & $\begin{array}{l}\text { Marsh } \\
\text { Creek }\end{array}$ & 03020201 & 2 & $1972-73$ & 2 & 0 \\
\hline 219 & 0208732880 & $\begin{array}{l}\text { Marsh Creek tributary no. } 2 \text { near Wilders } \\
\text { Grove }\end{array}$ & $35^{\circ} 49^{\prime} 23^{\prime \prime}$ & $78^{\circ} 35^{\prime} 09^{\prime \prime}$ & Wake & Raleigh East & $0.6^{\mathrm{a}}$ & $\begin{array}{l}\text { Marsh } \\
\text { Creek }\end{array}$ & 03020201 & 2 & 1972,1975 & 6 & 0 \\
\hline 220 & 0208732885 & Marsh Creek near New Hope & $35^{\circ} 48^{\prime} 59^{\prime \prime}$ & $78^{\circ} 35^{\prime} 37^{\prime \prime}$ & Wake & Raleigh East & 6.84 & $\begin{array}{r}\text { Crabtree } \\
\text { Creek }\end{array}$ & 03020201 & 1 & Jan. 1984 - Sept. 1996 & N/A & N/A \\
\hline 221 & 02087329 & Marsh Creek near Raleigh & $35^{\circ} 48^{\prime} 17^{\prime \prime}$ & $78^{\circ} 35^{\prime} 29^{\prime \prime}$ & Wake & Raleigh East & 8.41 & $\begin{array}{r}\text { Crabtree } \\
\text { Creek }\end{array}$ & 03020201 & 2 & $1961-62$ & 2 & 0 \\
\hline 222 & 02087331 & Crabtree Creek at U.S. 64 near Raleigh & $35^{\circ} 47^{\prime} 28^{\prime \prime}$ & $78^{\circ} 35^{\prime} 12^{\prime \prime}$ & Wake & Raleigh East & 138 & Neuse River & 03020201 & 2 & $1961-62,1973,1997$ & 7 & 0 \\
\hline 223 & 02087334 & Crabtree Creek at mouth near Knightdale & $35^{\circ} 45^{\prime} 56^{\prime \prime}$ & $78^{\circ} 32^{\prime} 24^{\prime \prime}$ & Wake & Raleigh East & 146 & Neuse River & 03020201 & 2 & $1961-62,1997$ & 4 & 0 \\
\hline
\end{tabular}


Table 5. Summary of continuous-record gaging stations and partial-record measuring sites in the Neuse River Basin in North Carolina where records of gage height and streamflow were collected-Continued

$\left[\mathrm{mi}^{2}\right.$, square mile; SR, secondary road; N/A, not applicable; SEO, sewage effluent outfall. Sites shaded in gray indicate those sites for which low-flow characteristics have been developed. Period of record for continuous-record sites (site type 1) is shown in months and years; period of record for partial-record sites (site type 2) is shown in water years in which discharge measurements were made

\begin{tabular}{|c|c|c|c|c|c|c|c|c|c|c|c|c|c|}
\hline \multirow{2}{*}{ 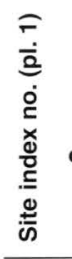 } & \multirow[t]{2}{*}{$\begin{array}{c}\text { USGS } \\
\text { downstream } \\
\text { order number }\end{array}$} & \multirow[t]{2}{*}{ Station name } & \multirow[t]{2}{*}{ Latitude } & \multirow[t]{2}{*}{ Longitude } & \multirow[t]{2}{*}{ County } & \multirow[t]{2}{*}{$\begin{array}{c}\text { USGS } \\
\text { topographic } \\
\text { quadrangle }\end{array}$} & \multirow[t]{2}{*}{$\begin{array}{l}\text { Drainage } \\
\text { area } \\
\left(\mathrm{mi}^{2}\right)\end{array}$} & \multirow[t]{2}{*}{$\begin{array}{l}\text { Tributary } \\
\text { to }\end{array}$} & \multirow[t]{2}{*}{$\begin{array}{l}\text { Hydrologic } \\
\text { unit } \\
\text { code }\end{array}$} & \multirow[t]{2}{*}{$\begin{array}{l}\sum_{2}^{\infty} \\
\stackrel{ \pm}{\infty}\end{array}$} & \multirow[t]{2}{*}{ Period of record } & \multicolumn{2}{|c|}{$\begin{array}{l}\text { Number of } \\
\text { measure- } \\
\text { ments for } \\
\text { partial-record } \\
\text { sites }\end{array}$} \\
\hline & & & & & & & & & & & & Flow & $\begin{array}{l}\text { Zero } \\
\text { flow }\end{array}$ \\
\hline 224 & 02087337 & $\begin{array}{l}\text { Walnut Creek at Buck Jones Road near } \\
\text { Raleigh }\end{array}$ & $35^{\circ} 46^{\prime} 22^{\prime \prime}$ & $78^{\circ} 44^{\prime} 15^{\prime \prime}$ & Wake & Raleigh West & 3.36 & Neuse River & 03020201 & 2 & 1963,1973 & 7 & 0 \\
\hline 225 & 02087338 & $\begin{array}{l}\text { Walnut Creek above Lake Johnson near } \\
\text { Raleigh }\end{array}$ & $35^{\circ} 466^{\prime \prime}$ & $78^{\circ} 43^{\prime} 25^{\prime \prime}$ & Wake & Raleigh West & 5.25 & Neuse River & 03020201 & 2 & $1930,1932,1952$ & 3 & 0 \\
\hline 226 & 02087341 & Simmons Branch near Raleigh & $35^{\circ} 46^{\prime} 00^{\prime \prime}$ & $78^{\circ} 42^{\prime} 02^{\prime \prime}$ & Wake & Raleigh West & 1.16 & $\begin{array}{l}\text { Walnut } \\
\text { Creek }\end{array}$ & 03020201 & 2 & 1953 & 1 & 0 \\
\hline 227 & 02087343 & Bushy Branch near Raleigh & $35^{\circ} 46^{\prime} 10^{\prime \prime}$ & $78^{\circ} 41^{\prime} 23^{\prime \prime}$ & Wake & Raleigh West & 1.89 & $\begin{array}{l}\text { Walnut } \\
\text { Creek }\end{array}$ & 03020201 & 2 & 1953 & 1 & 0 \\
\hline 228 & 0208734550 & Walnut Creek at SR 1009 near Raleigh & $35^{\circ} 45^{\prime} 30^{\prime \prime}$ & $78^{\circ} 39^{\prime} 51^{\prime \prime}$ & Wake & Raleigh West & 14.4 & Neuse River & 03020201 & 2 & $1972-73$ & 6 & 0 \\
\hline 229 & 02087349 & $\begin{array}{l}\text { Rocky Branch at Dan Allen Drive at } \\
\text { Raleigh }\end{array}$ & $35^{\circ} 46^{\prime} 55^{\prime \prime}$ & $78^{\circ} 40^{\prime} 20^{\prime \prime}$ & Wake & Raleigh West & 0.56 & $\begin{array}{l}\text { Walnut } \\
\text { Creek }\end{array}$ & 03020201 & 2 & $1966-67$ & 2 & 0 \\
\hline 230 & 02087350 & $\begin{array}{l}\text { Rocky Branch at Carmichael Gymnasium } \\
\text { at Raleigh }\end{array}$ & $35^{\circ} 46^{\prime} 50^{\prime \prime}$ & $78^{\circ} 40^{\prime} 09^{\prime \prime}$ & Wake & Raleigh West & 0.78 & $\begin{array}{l}\text { Walnut } \\
\text { Creek }\end{array}$ & 03020201 & 2 & $1966-67$ & 2 & 0 \\
\hline 231 & 02087351 & Rocky Branch at Raleigh & $35^{\circ} 45^{\prime} 30^{\prime \prime}$ & $78^{\circ} 38^{\prime} 25^{\prime \prime}$ & Wake & Raleigh West & 2.97 & $\begin{array}{l}\text { Walnut } \\
\text { Creek }\end{array}$ & 03020201 & 2 & 1953 & 1 & 0 \\
\hline 232 & 02087354 & Wildcat Branch at Raleigh & $35^{\circ} 45^{\prime} 20^{\prime \prime}$ & $78^{\circ} 38^{\prime} 10^{\prime \prime}$ & Wake & Raleigh West & 1.94 & $\begin{array}{l}\text { Walnut } \\
\text { Creek }\end{array}$ & 03020201 & 2 & 1953 & 2 & 0 \\
\hline 233 & 02087355 & $\begin{array}{l}\text { Walnut Creek at Rock Quarry Road at } \\
\text { Raleigh }\end{array}$ & $35^{\circ} 45^{\prime} 44^{\prime \prime}$ & $78^{\circ} 362^{\prime \prime}$ & Wake & Raleigh East & 24.7 & Neuse River & 03020201 & 2 & $1963,1973-74$ & 7 & 0 \\
\hline 234 & 02087356 & Walnut Creek tributary near Raleigh & $35^{\circ} 46^{\prime} 05^{\prime \prime}$ & $78^{\circ} 36^{\prime} 10^{\prime \prime}$ & Wake & Raleigh East & 0.26 & $\begin{array}{l}\text { Walnut } \\
\text { Creek }\end{array}$ & 03020201 & 2 & 1967 & 1 & 0 \\
\hline 235 & 02087357 & Walnut Creek tributary 2 near Raleigh & $35^{\circ} 44^{\prime} 57^{\prime \prime}$ & $78^{\circ} 36^{\prime} 46^{\prime \prime}$ & Wake & Garner & 0.76 & $\begin{array}{l}\text { Walnut } \\
\text { Creek }\end{array}$ & 03020201 & 2 & 1967 & 1 & 0 \\
\hline \multirow[t]{2}{*}{236} & 02087359 & $\begin{array}{l}\text { Walnut Creek at Sunnybrook Road at } \\
\text { Raleigh }\end{array}$ & $35^{\circ} 45^{\prime} 30^{\prime \prime}$ & $78^{\circ} 35^{\prime} 00^{\prime \prime}$ & Wake & Raleigh East & 29.4 & Neuse River & 03020201 & 1 & May 1996 - Sept. 1996 & N/A & N/A \\
\hline & & & & & & & & & & 2 & $1973-75$ & 6 & 0 \\
\hline 237 & 02087367 & Big Branch near Auburn & $35^{\circ} 42^{\prime} 38^{\prime \prime}$ & $78^{\circ} 33^{\prime} 53^{\prime \prime}$ & Wake & Garner & 2.20 & $\begin{array}{l}\text { Walnut } \\
\text { Creek }\end{array}$ & 03020201 & 2 & $1967,1974-75$ & 5 & 0 \\
\hline 238 & 02087368 & Big Branch tributary near Garner & $35^{\circ} 43^{\prime} 28^{\prime \prime}$ & $78^{\circ} 34^{\prime} 24^{\prime \prime}$ & Wake & Garner & 1.08 & Big Branch & 03020201 & 2 & $1945,1955,1974-75$ & 7 & 0 \\
\hline
\end{tabular}




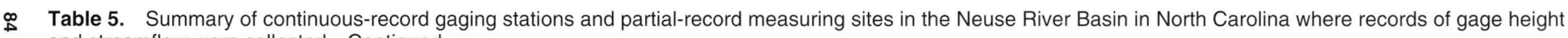
and streamflow were collected-Continued

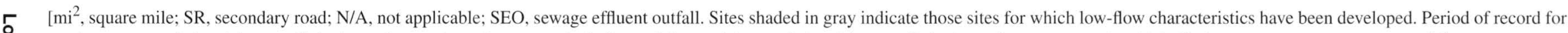
continuous-record sites (site type 1) is shown in months and years; period of record for partial-record sites (site type 2) is shown in water years in which discharge measurements were made]

\begin{tabular}{|c|c|c|c|c|c|c|c|c|c|c|c|c|c|}
\hline 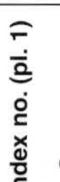 & $\begin{array}{c}\text { USGS } \\
\text { downstream } \\
\text { order number }\end{array}$ & Station name & Latitude & Longitude & County & $\begin{array}{c}\text { USGS } \\
\text { topographic } \\
\text { quadrangle }\end{array}$ & $\begin{array}{c}\text { Drainage } \\
\text { area } \\
\left(\mathrm{mi}^{2}\right)\end{array}$ & $\begin{array}{l}\text { Tributary } \\
\text { to }\end{array}$ & $\begin{array}{l}\text { Hydrologic } \\
\text { unit } \\
\text { code }\end{array}$ & 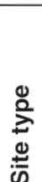 & Period of record & $\begin{array}{r}\text { Num } \\
\text { mea } \\
\text { men } \\
\text { partial } \\
\text { si }\end{array}$ & $\begin{array}{l}\text { er of } \\
\text { ure- } \\
\text { for } \\
\text { ecord } \\
\text { s }\end{array}$ \\
\hline 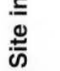 & & & & & & & & & & & & Flow & $\begin{array}{l}\text { Zero } \\
\text { flow }\end{array}$ \\
\hline 239 & 02087369 & Little Arm Branch near Garner & $35^{\circ} 43^{\prime} 40^{\prime \prime}$ & $78^{\circ} 36^{\prime} 02^{\prime \prime}$ & Wake & Garner & 2.26 & Big Branch & 03020201 & 2 & 1967 & 1 & 0 \\
\hline 240 & 02087370 & Big Branch near Garner & $35^{\circ} 44^{\prime} 28^{\prime \prime}$ & $78^{\circ} 34^{\prime} 06^{\prime \prime}$ & Wake & Garner & 11.8 & $\begin{array}{l}\text { Walnut } \\
\text { Creek }\end{array}$ & 03020201 & 2 & $\begin{array}{l}\text { 1953-58, 1960, 1970, } \\
1972-73,1976,1979-80\end{array}$ & 30 & 0 \\
\hline 241 & 02087376 & Walnut Creek above mouth near Raleigh & $35^{\circ} 45^{\prime} 00^{\prime \prime}$ & $78^{\circ} 32^{\prime} 05^{\prime \prime}$ & Wake & Garner & 46.0 & Neuse River & 03020201 & 2 & 1973, 1997 & 6 & 0 \\
\hline 242 & 02087386 & $\begin{array}{l}\text { Neuse River tributary No. } 5 \text { near } \\
\text { Knightdale }\end{array}$ & $35^{\circ} 45^{\prime} 15^{\prime \prime}$ & $78^{\circ} 30^{\prime} 31^{\prime \prime}$ & Wake & Raleigh East & 2.29 & Neuse River & 03020201 & 2 & $1954,1972-74$ & 6 & 0 \\
\hline 243 & 02087396 & Neuse River near Knightdale & $35^{\circ} 43^{\prime} 36^{\prime \prime}$ & $78^{\circ} 30^{\prime} 51^{\prime \prime}$ & Wake & Garner & 1,081 & $\begin{array}{l}\text { Atlantic } \\
\text { Ocean }\end{array}$ & 03020201 & 2 & $1955,1968,1972-74$ & 6 & 0 \\
\hline 244 & 02087408 & Poplar Creek near Wendell & $35^{\circ} 44^{\prime} 55^{\prime \prime}$ & $78^{\circ} 27^{\prime} 58^{\prime \prime}$ & Wake & Clayton & 5.40 & Neuse River & 03020201 & 2 & 1967 & 1 & 0 \\
\hline 245 & 02087410 & Poplar Creek near Knightdale & $35^{\circ} 43^{\prime} 51^{\prime \prime}$ & $78^{\circ} 28^{\prime} 40^{\prime \prime}$ & Wake & Clayton & 8.83 & Neuse River & 03020201 & 2 & $\begin{array}{l}\text { 1954-58, 1960, 1963, } \\
1970\end{array}$ & 14 & 0 \\
\hline 246 & 02087416 & $\begin{array}{l}\text { Neuse River at County Line near } \\
\text { Knightdale }\end{array}$ & $35^{\circ} 42^{\prime} 08^{\prime \prime}$ & $78^{\circ} 28^{\prime} 43^{\prime \prime}$ & Wake & Clayton & 1,097 & Neuse River & 03020201 & 2 & 1973 & 1 & 0 \\
\hline 247 & 02087499 & $\begin{array}{l}\text { Neuse River tributary above SR } 1705 \text { near } \\
\quad \text { Clayton }\end{array}$ & $35^{\circ} 39^{\prime} 05^{\prime \prime}$ & $78^{\circ} 24^{\prime} 11^{\prime \prime}$ & Johnston & Clayton & $1.3^{\mathrm{a}}$ & Neuse River & 03020201 & 2 & 1979 & 1 & 0 \\
\hline 248 & 02087500 & Neuse River near Clayton & $35^{\circ} 38^{\prime} 50^{\prime \prime}$ & $78^{\circ} 24^{\prime} 21^{\prime \prime}$ & Johnston & Clayton & 1,150 & $\begin{array}{l}\text { Atlantic } \\
\text { Ocean }\end{array}$ & 03020201 & 1 & July 1927 - Sept. 1996 & N/A & N/A \\
\hline 249 & 0208753180 & Mill Creek at SR 1929 at Selma & $35^{\circ} 32^{\prime} 41^{\prime \prime}$ & $78^{\circ} 17^{\prime} 45^{\prime \prime}$ & Johnston & Selma & $3.6^{\mathrm{a}}$ & Neuse River & 03020201 & 2 & $1973-74$ & 5 & 1 \\
\hline 250 & 02087532 & Mill Creek at Selma & $35^{\circ} 32^{\prime} 35^{\prime \prime}$ & $78^{\circ} 18^{\prime} 02^{\prime \prime}$ & Johnston & Selma & 4.05 & Neuse River & 03020201 & 2 & $1955,1972-74$ & 7 & 3 \\
\hline 251 & 02087533 & Mill Creek near Selma & $35^{\circ} 32^{\prime} 41^{\prime \prime}$ & $78^{\circ} 18^{\prime} 38^{\prime \prime}$ & Johnston & Selma & 4.36 & Neuse River & 03020201 & 2 & $1972-73$ & 3 & 0 \\
\hline 252 & 0208754505 & $\begin{array}{l}\text { Little Poplar Creek at SR } 1900 \text { near } \\
\text { Powhatan }\end{array}$ & $35^{\circ} 35^{\prime} 27^{\prime \prime}$ & $78^{\circ} 23^{\prime} 45^{\prime \prime}$ & Johnston & Powhatan & 1.76 & $\begin{array}{l}\text { Poplar } \\
\text { Branch }\end{array}$ & 03020201 & 2 & 1986 & 1 & 1 \\
\hline 253 & 02087552 & Poplar Branch near Smithfield & $35^{\circ} 32^{\prime} 18^{\prime \prime}$ & $78^{\circ} 21^{\prime} 02^{\prime \prime}$ & Johnston & Selma & 11.1 & Neuse River & 03020201 & 2 & 1954 & 1 & 0 \\
\hline
\end{tabular}


Table 5. Summary of continuous-record gaging stations and partial-record measuring sites in the Neuse River Basin in North Carolina where records of gage height and streamflow were collected-Continued

$\left[\mathrm{mi}^{2}\right.$, square mile; SR, secondary road; N/A, not applicable; SEO, sewage effluent outfall. Sites shaded in gray indicate those sites for which low-flow characteristics have been developed. Period of record for continuous-record sites (site type 1) is shown in months and years; period of record for partial-record sites (site type 2) is shown in water years in which discharge measurements were made]

\begin{tabular}{|c|c|c|c|c|c|c|c|c|c|c|c|c|c|}
\hline \multirow{2}{*}{ 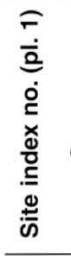 } & \multirow[t]{2}{*}{$\begin{array}{l}\text { USGS } \\
\text { downstream } \\
\text { order number }\end{array}$} & \multirow[t]{2}{*}{ Station name } & \multirow[t]{2}{*}{ Latitude } & \multirow[t]{2}{*}{ Longitude } & \multirow[t]{2}{*}{ County } & \multirow[t]{2}{*}{$\begin{array}{l}\text { USGS } \\
\text { topographic } \\
\text { quadrangle }\end{array}$} & \multirow[t]{2}{*}{$\begin{array}{l}\text { Drainage } \\
\text { area } \\
\left(\mathrm{mi}^{2}\right)\end{array}$} & \multirow[t]{2}{*}{$\begin{array}{l}\text { Tributary } \\
\text { to }\end{array}$} & \multirow[t]{2}{*}{$\begin{array}{l}\text { Hydrologic } \\
\text { unit } \\
\text { code }\end{array}$} & \multirow[t]{2}{*}{ 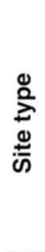 } & \multirow[t]{2}{*}{ Period of record } & \multicolumn{2}{|c|}{$\begin{array}{l}\text { Number of } \\
\text { measure- } \\
\text { ments for } \\
\text { partial-record } \\
\text { sites }\end{array}$} \\
\hline & & & & & & & & & & & & Flow & $\begin{array}{l}\text { Zero } \\
\text { flow }\end{array}$ \\
\hline 254 & 02087570 & Neuse River at Smithfield & $35^{\circ} 30^{\prime} 46^{\prime \prime}$ & $78^{\circ} 21^{\prime} 00^{\prime \prime}$ & Johnston & Selma & 1,206 & $\begin{array}{l}\text { Atlantic } \\
\text { Ocean }\end{array}$ & 03020201 & 1 & $\begin{array}{l}\text { Oct. } 1959 \text { - Sept. } 1991 \\
\text { (medium/high flows } \\
\text { only prior to Oct. 1970) }\end{array}$ & N/A & N/A \\
\hline & & & & & & & & & & 2 & $1925,1955,1968$ & 3 & 0 \\
\hline 255 & 02087578 & Williams Creek at dam near Apex & $35^{\circ} 44^{\prime} 48^{\prime \prime}$ & $78^{\circ} 49^{\prime} 04^{\prime \prime}$ & Wake & Apex & 2.22 & Swift Creek & 03020201 & 2 & 1963 & 1 & 0 \\
\hline 256 & 02087580 & Swift Creek near Apex & $35^{\circ} 43^{\prime} 07^{\prime \prime}$ & $78^{\circ} 45^{\prime} 09^{\prime \prime}$ & Wake & Apex & 21.0 & Neuse River & 03020201 & 2 & $\begin{array}{l}1958,1961-71^{b}, 1992- \\
95,1997\end{array}$ & 58 & 0 \\
\hline 257 & 02087584 & Swift Creek near Macedonia & $35^{\circ} 42^{\prime} 00^{\prime \prime}$ & $78^{\circ} 43^{\prime} 00^{\prime \prime}$ & Wake & Lake Wheeler & 26.9 & Neuse River & 03020201 & 2 & 1954 & 1 & 0 \\
\hline 258 & 0208758450 & $\begin{array}{l}\text { Dutchmans Branch near McCullers Cross- } \\
\text { roads }\end{array}$ & $35^{\circ} 41^{\prime} 28^{\prime \prime}$ & $78^{\circ} 43^{\prime} 30^{\prime \prime}$ & Wake & Lake Wheeler & 5.23 & Swift Creek & 03020201 & 2 & $1987-92$ & 16 & 0 \\
\hline 259 & 02087588 & $\begin{array}{l}\text { Swift Creek at Lake Wheeler Dam near } \\
\text { Raleigh }\end{array}$ & $35^{\circ} 41^{\prime} 39^{\prime \prime}$ & $78^{\circ} 41^{\prime} 39^{\prime \prime}$ & Wake & Lake Wheeler & 35.8 & Neuse River & 03020201 & 2 & 1973-74 & 3 & 0 \\
\hline 260 & 0208758850 & Swift Creek near McCullers Crossroads & $35^{\circ} 41^{\prime} 33^{\prime \prime}$ & $78^{\circ} 41^{\prime} 34^{\prime \prime}$ & Wake & Lake Wheeler & 35.8 & Neuse River & 03020201 & 1 & Dec. 1987 - Sept. 1996 & N/A & N/A \\
\hline 261 & 02087590 & Swift Creek above McCullers & $35^{\circ} 41^{\prime} 15^{\prime \prime}$ & $78^{\circ} 40^{\prime} 52^{\prime \prime}$ & Wake & Lake Wheeler & 38.0 & Neuse River & 03020201 & 2 & $1930,1949-50,1954-55$ & 8 & 0 \\
\hline 262 & 02087610 & Swift Creek near McCullers & $35^{\circ} 40^{\prime} 55^{\prime \prime}$ & $78^{\circ} 39^{\prime} 12^{\prime \prime}$ & Wake & Lake Wheeler & $41.8^{\mathrm{d}}$ & Neuse River & 03020201 & 2 & $1932,1949-53$ & 16 & 0 \\
\hline 263 & 02087641 & Reedy Branch near Raleigh & $35^{\circ} 40^{\prime} 04^{\prime \prime}$ & $78^{\circ} 36^{\prime} 44^{\prime \prime}$ & Wake & Lake Wheeler & 5.21 & Swift Creek & 03020201 & 2 & 1953 & 1 & 0 \\
\hline 264 & 02087671 & Swift Creek tributary near Raleigh & $35^{\circ} 40^{\prime} 04^{\prime \prime}$ & $78^{\circ} 36^{\prime} 44^{\prime \prime}$ & Wake & Garner & 2.04 & Swift Creek & 03020201 & 2 & 1932,1953 & 2 & 0 \\
\hline 265 & 0208770150 & Swift Creek at NC 50 near Garner & $35^{\circ} 39^{\prime} 39^{\prime \prime}$ & $78^{\circ} 36^{\prime} 37^{\prime \prime}$ & Wake & Garner & 66.3 & Neuse River & 03020201 & 2 & 1997 & 2 & 0 \\
\hline 266 & 0208772185 & Swift Creek near Drug Store & $35^{\circ} 3647^{\prime \prime}$ & $78^{\circ} 32^{\prime} 57^{\prime \prime}$ & Johnston & Edmondson & 86.6 & Neuse River & 03020201 & 2 & 1984-97 & 40 & 1 \\
\hline 267 & 02087731 & White Oak Creek near Clayton & $35^{\circ} 37^{\prime} 04^{\prime \prime}$ & $78^{\circ} 31^{\prime} 42^{\prime \prime}$ & Johnston & Edmondson & 13.5 & Swift Creek & 03020201 & 2 & 1958,1986 & 2 & 1 \\
\hline 268 & 02087761 & Little Creek above Clayton & $35^{\circ} 39^{\prime} 18^{\prime \prime}$ & $78^{\circ} 28^{\prime} 52^{\prime \prime}$ & Johnston & Clayton & 3.84 & Swift Creek & 03020201 & 2 & $\begin{array}{l}1954-55,1958,1971, \\
1986\end{array}$ & 9 & 1 \\
\hline 269 & 02087771 & Little Creek at Clayton & $35^{\circ} 38^{\prime} 39^{\prime \prime}$ & $78^{\circ} 27^{\prime} 55^{\prime \prime}$ & Johnston & Clayton & 5.52 & Swift Creek & 03020201 & 2 & $1972-74$ & 5 & 0 \\
\hline
\end{tabular}




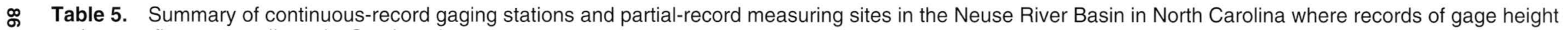
and streamflow were collected-Continued

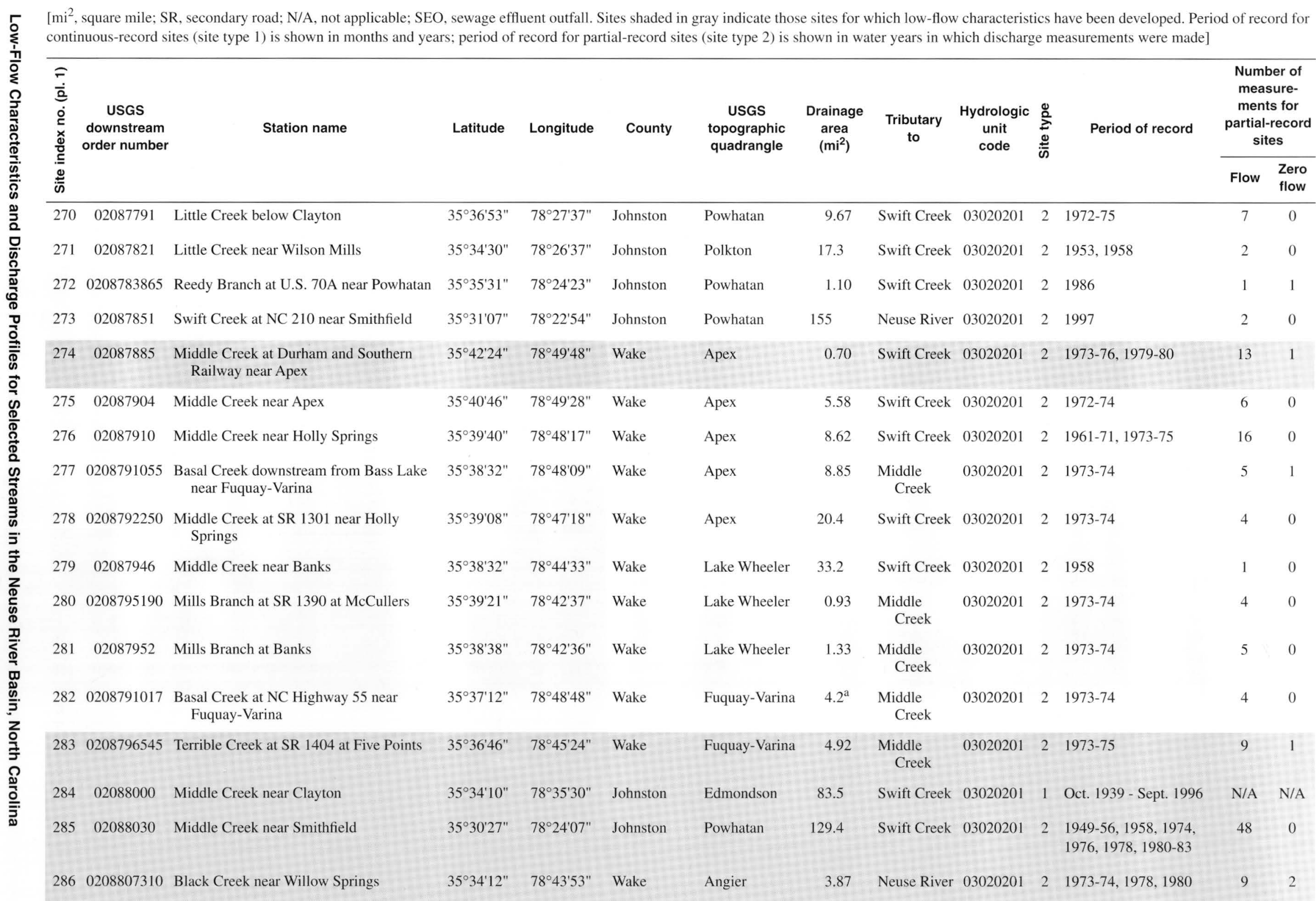


Table 5. Summary of continuous-record gaging stations and partial-record measuring sites in the Neuse River Basin in North Carolina where records of gage height and streamflow were collected-Continued

$\left[\mathrm{mi}^{2}\right.$, square mile; SR, secondary road; N/A, not applicable; SEO, sewage effluent outfall. Sites shaded in gray indicate those sites for which low-flow characteristics have been developed. Period of record for continuous-record sites (site type 1) is shown in months and years; period of record for partial-record sites (site type 2) is shown in water years in which discharge measurements were made]

\begin{tabular}{|c|c|c|c|c|c|c|c|c|c|c|c|c|c|}
\hline \multirow{2}{*}{ 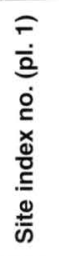 } & \multirow[t]{2}{*}{$\begin{array}{c}\text { USGS } \\
\text { downstream } \\
\text { order number }\end{array}$} & \multirow[t]{2}{*}{ Station name } & \multirow[t]{2}{*}{ Latitude } & \multirow[t]{2}{*}{ Longitude } & \multirow[t]{2}{*}{ County } & \multirow[t]{2}{*}{$\begin{array}{c}\text { USGS } \\
\text { topographic } \\
\text { quadrangle }\end{array}$} & \multirow[t]{2}{*}{$\begin{array}{c}\text { Drainage } \\
\text { area } \\
\left(\mathrm{mi}^{2}\right)\end{array}$} & \multirow[t]{2}{*}{$\begin{array}{l}\text { Tributary } \\
\text { to }\end{array}$} & \multirow[t]{2}{*}{$\begin{array}{l}\text { Hydrologic } \\
\text { unit } \\
\text { code }\end{array}$} & \multirow[t]{2}{*}{$\begin{array}{l}\sum_{2}^{0} \\
\text { के } \\
\text { के }\end{array}$} & \multirow[t]{2}{*}{ Period of record } & \multicolumn{2}{|c|}{$\begin{array}{l}\text { Number of } \\
\text { measure- } \\
\text { ments for } \\
\text { partial-record } \\
\text { sites }\end{array}$} \\
\hline & & & & & & & & & & & & Flow & $\begin{array}{l}\text { Zero } \\
\text { flow }\end{array}$ \\
\hline 287 & 02088076 & Black Creek near Macks & $35^{\circ} 28^{\prime} 00^{\prime \prime}$ & $78^{\circ} 33^{\prime} 00^{\prime \prime}$ & Johnston & Benson & 64.1 & Neuse River & 03020201 & 2 & 1958 & 1 & 0 \\
\hline 288 & 02088090 & Black Creek near Four Oaks & $35^{\circ} 28^{\prime} 09^{\prime \prime}$ & $78^{\circ} 27^{\prime} 26^{\prime \prime}$ & Johnston & Four Oaks & 81.9 & Neuse River & 03020201 & 2 & $\begin{array}{l}1949-55,1958-59,1974- \\
75\end{array}$ & 19 & 1 \\
\hline 289 & 0208810395 & $\begin{array}{l}\text { Black Creek at U.S. Highway } 301 \text { near } \\
\text { Four Oaks }\end{array}$ & $35^{\circ} 28^{\prime} 02^{\prime \prime}$ & $78^{\circ} 23^{\prime} 27^{\prime \prime}$ & Johnston & Four Oaks & 99.0 & Neuse River & 03020201 & 2 & 1974 & 1 & 0 \\
\hline 290 & 02088116 & Bawdy Creek near Princeton & $35^{\circ} 24 ' 21 "$ & $78^{\circ} 12^{\prime} 59^{\prime \prime}$ & Johnston & Princeton & 22.3 & Neuse River & 03020201 & 2 & 1954 & 1 & 1 \\
\hline 291 & 02088119 & Neuse River near Cox Mill & $35^{\circ} 22^{\prime} 27^{\prime \prime}$ & $78^{\circ} 11^{\prime} 47^{\prime \prime}$ & Johnston & Grantham & 1677 & $\begin{array}{l}\text { Atlantic } \\
\text { Ocean }\end{array}$ & 03020201 & 2 & $\begin{array}{l}1956,1968,1976,1978 \\
1980\end{array}$ & 7 & 0 \\
\hline 292 & 02088131 & Raccoon Swamp near Princeton & $35^{\circ} 22^{\prime} 00^{\prime \prime}$ & $78^{\circ} 10^{\prime} 00^{\prime \prime}$ & Johnston & Grantham & 2.46 & Neuse River & 03020201 & 2 & 1954,1958 & 2 & 2 \\
\hline 293 & 0208813560 & Mill Creek at SR 1124 near Parkers Mill & $35^{\circ} 17^{\prime} 14^{\prime \prime}$ & $78^{\circ} 25^{\prime} 52^{\prime \prime}$ & Johnston & Four Oaks & 20.1 & Neuse River & 03020201 & 2 & $1974-75$ & 7 & 0 \\
\hline 294 & 02088136 & Mill Creek at Overshot & $35^{\circ} 18^{\prime} 51^{\prime \prime}$ & $78^{\circ} 21^{\prime} 10^{\prime \prime}$ & Johnston & Four Oaks & 46.7 & Neuse River & 03020201 & 2 & 1958 & 1 & 0 \\
\hline 295 & 02088140 & Stone Creek near Newton Grove & $35^{\circ} 20^{\prime} 25^{\prime \prime}$ & $78^{\circ} 21^{\prime} 54^{\prime \prime}$ & Johnston & Four Oaks & 27.8 & Mill Creek & 03020201 & 2 & $1955,1961-71$ & 14 & 0 \\
\hline 296 & 02088210 & Hannah Creek near Benson & $35^{\circ} 24^{\prime} 13^{\prime \prime}$ & $78^{\circ} 31^{\prime} 02^{\prime \prime}$ & Johnston & Benson & 2.68 & Mill Creek & 03020201 & 2 & $1954,1961-71$ & 13 & 1 \\
\hline 297 & 02088216 & Driving Branch near Benson & $35^{\circ} 23^{\prime} 12^{\prime \prime}$ & $78^{\circ} 30^{\prime} 55^{\prime \prime}$ & Johnston & Benson & 1.73 & $\begin{array}{l}\text { Hannah } \\
\text { Creek }\end{array}$ & 03020201 & 2 & $1972-74$ & 6 & 2 \\
\hline 298 & 02088217 & Hannah Creek near Alaska & $35^{\circ} 23^{\prime} 50^{\prime \prime}$ & $78^{\circ} 30^{\prime} 00^{\prime \prime}$ & Johnston & Benson & 12.2 & Mill Creek & 03020201 & 2 & 1973-75 & 7 & 2 \\
\hline 299 & 02088218 & Hannah Creek below Benson & $35^{\circ} 24^{\prime} 00^{\prime \prime}$ & $78^{\circ} 30^{\prime} 00^{\prime \prime}$ & Johnston & Four Oaks & 12.7 & Mill Creek & 03020201 & 2 & 1955 & 4 & 2 \\
\hline 300 & 02088221 & Stony Fork near Four Oaks & $35^{\circ} 25^{\prime} 08^{\prime \prime}$ & $78^{\circ} 29^{\prime} 20^{\prime \prime}$ & Johnston & Four Oaks & 7.98 & $\begin{array}{l}\text { Hannah } \\
\text { Creek }\end{array}$ & 03020201 & 2 & 1958 & 1 & 0 \\
\hline 301 & 02088240 & Hannah Creek near Blackman & $35^{\circ} 23^{\prime} 50^{\prime \prime}$ & $78^{\circ} 26^{\prime} 00^{\prime \prime}$ & Johnston & Four Oaks & 34.7 & Mill Creek & 03020201 & 2 & $1957-65$ & 14 & 3 \\
\hline 302 & 02088248 & Juniper Swamp near Four Oaks & $35^{\circ} 25^{\prime} 12^{\prime \prime}$ & $78^{\circ} 24^{\prime} 40^{\prime \prime}$ & Johnston & Four Oaks & 4.17 & $\begin{array}{l}\text { Hannah } \\
\text { Creek }\end{array}$ & 03020201 & 2 & 1958 & 1 & 1 \\
\hline 303 & 02088251 & Juniper Swamp tributary near Four Oaks & $35^{\circ} 25^{\prime} 35^{\prime \prime}$ & $78^{\circ} 24^{\prime} 20^{\prime \prime}$ & Johnston & Four Oaks & 1.40 & $\begin{array}{l}\text { Juniper } \\
\text { Swamp }\end{array}$ & 03020201 & 2 & 1958 & 1 & 1 \\
\hline
\end{tabular}




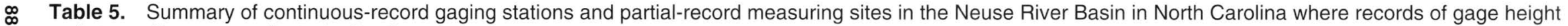
and streamflow were collected-Continued

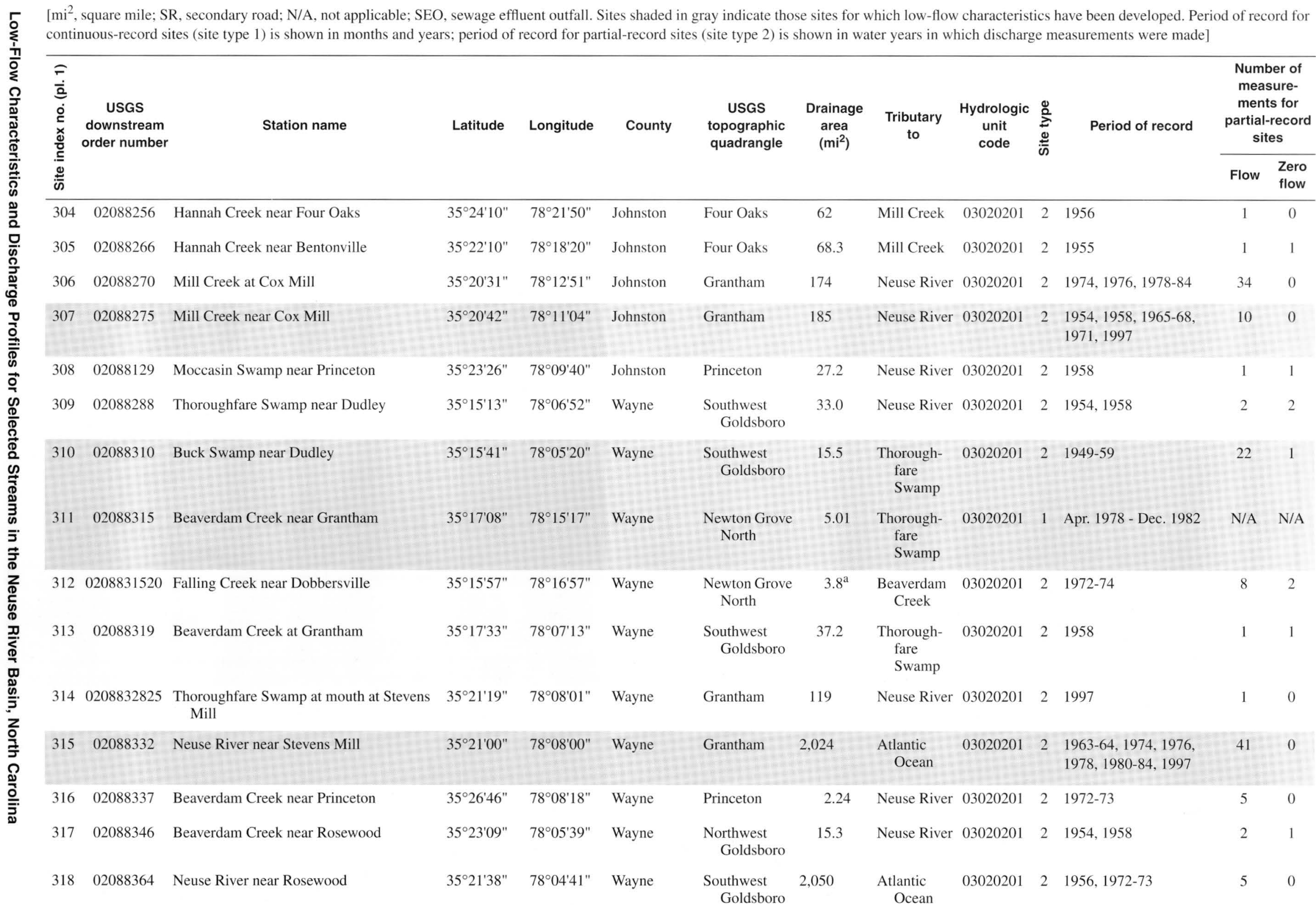


Table 5. Summary of continuous-record gaging stations and partial-record measuring sites in the Neuse River Basin in North Carolina where records of gage height and streamflow were collected-Continued

$\left[\mathrm{mi}^{2}\right.$, square mile; SR, secondary road; N/A, not applicable; SEO, sewage effluent outfall. Sites shaded in gray indicate those sites for which low-flow characteristics have been developed. Period of record for continuous-record sites (site type 1) is shown in months and years; period of record for partial-record sites (site type 2) is shown in water years in which discharge measurements were made]

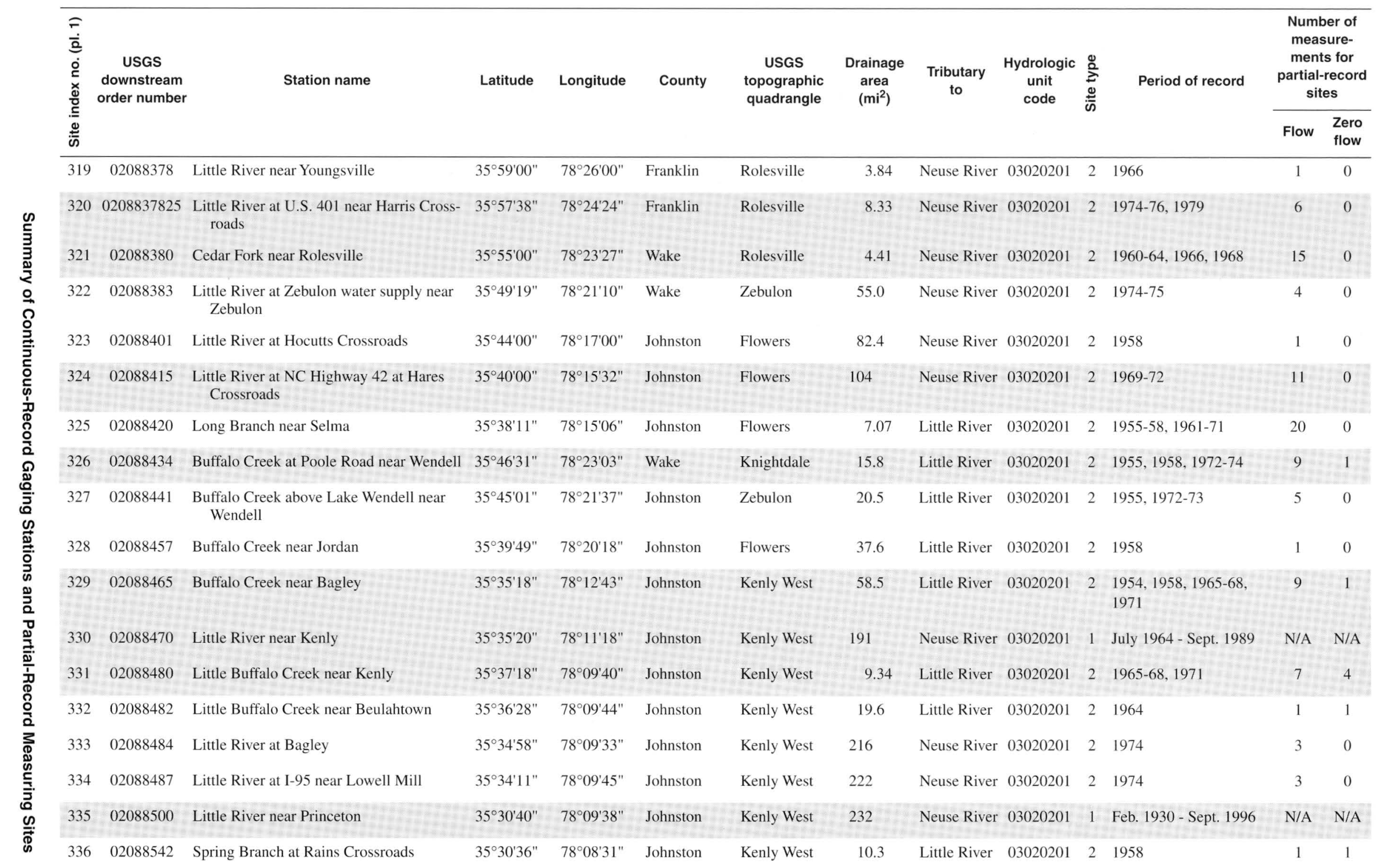




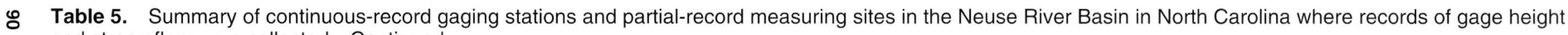
and streamflow were collected-Continued

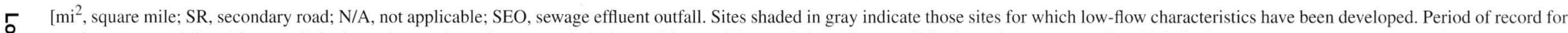
continuous-record sites (site type 1) is shown in months and years; period of record for partial-record sites (site type 2) is shown in water years in which discharge measurements were made]

\begin{tabular}{|c|c|c|c|c|c|c|c|c|c|c|c|c|c|}
\hline \multirow{2}{*}{ 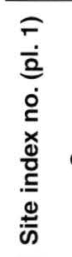 } & \multirow[t]{2}{*}{$\begin{array}{c}\text { USGS } \\
\text { downstream } \\
\text { order number }\end{array}$} & \multirow[t]{2}{*}{ Station name } & \multirow[t]{2}{*}{ Latitude } & \multirow[t]{2}{*}{ Longitude } & \multirow[t]{2}{*}{ County } & \multirow[t]{2}{*}{$\begin{array}{c}\text { USGS } \\
\text { topographic } \\
\text { quadrangle }\end{array}$} & \multirow[t]{2}{*}{$\begin{array}{c}\text { Drainage } \\
\text { area } \\
\left(\mathrm{mi}^{2}\right)\end{array}$} & \multirow[t]{2}{*}{$\begin{array}{l}\text { Tributary } \\
\text { to }\end{array}$} & \multirow[t]{2}{*}{$\begin{array}{l}\text { Hydrologic } \\
\text { unit } \\
\text { code }\end{array}$} & \multirow[t]{2}{*}{$\begin{array}{l}\sum_{2}^{0} \\
0 \\
\vdots \\
\vdots\end{array}$} & \multirow[t]{2}{*}{ Period of record } & \multicolumn{2}{|c|}{$\begin{array}{c}\text { Number of } \\
\text { measure- } \\
\text { ments for } \\
\text { partial-record } \\
\text { sites }\end{array}$} \\
\hline & & & & & & & & & & & & Flow & $\begin{array}{l}\text { Zero } \\
\text { flow }\end{array}$ \\
\hline 337 & 0208854250 & Little River at SR 1002 near Princeton & $35^{\circ} 28^{\prime} 56^{\prime \prime}$ & $78^{\circ} 08^{\prime} 37^{\prime \prime}$ & Johnston & Princeton & $260^{\mathrm{a}}$ & Neuse River & 03020201 & 2 & 1973-74 & 3 & 0 \\
\hline 338 & 0208858110 & Little River at NC 581 near Asylum & $35^{\circ} 26^{\prime} 46^{\prime \prime}$ & $78^{\circ} 02^{\prime} 36^{\prime \prime}$ & Wayne & $\begin{array}{l}\text { Northwest } \\
\text { Goldsboro }\end{array}$ & 284 & Neuse River & 03020201 & 2 & $1974,1976,1978$ & 6 & 0 \\
\hline 339 & 02088584 & Little River tributary near Pikeville & $35^{\circ} 27^{\prime} 06^{\prime \prime}$ & $78^{\circ} 01^{\prime} 39^{\prime \prime}$ & Wayne & $\begin{array}{l}\text { Northwest } \\
\text { Goldsboro }\end{array}$ & 8.99 & Neuse River & 03020201 & 2 & 1958 & 1 & 0 \\
\hline 340 & 02088632 & Little River at NC 581 at Asylum & $35^{\circ} 23^{\prime} 55^{\prime \prime}$ & $78^{\circ} 01^{\prime} 35^{\prime \prime}$ & Wayne & $\begin{array}{l}\text { Northwest } \\
\text { Goldsboro }\end{array}$ & 314 & Neuse River & 03020201 & 2 & 1980-81, 1997 & 3 & 0 \\
\hline 341 & 02088682 & Big Ditch at Retha Street at Goldsboro & $35^{\circ} 22^{\prime} 16^{\prime \prime}$ & $78^{\circ} 00^{\prime} 15^{\prime \prime}$ & Wayne & $\begin{array}{l}\text { Southwest } \\
\text { Goldsboro }\end{array}$ & 2.17 & $\begin{array}{l}\text { Howell } \\
\text { Branch }\end{array}$ & 03020202 & 1 & Feb. 1980 - Sept. 1984 & N/A & N/A \\
\hline 342 & 02088949 & Neuse River tributary No. 3 at Genoa & $35^{\circ} 20^{\prime} 00^{\prime \prime}$ & $78^{\circ} 01^{\prime} 00^{\prime \prime}$ & Wayne & $\begin{array}{l}\text { Southwest } \\
\text { Goldsboro }\end{array}$ & 4.67 & Neuse River & 03020202 & 2 & $1954-55,1957$ & 3 & 0 \\
\hline 343 & 02088969 & Carroway Creek at SR 1918 near Genoa & $35^{\circ} 19^{\prime} 14^{\prime \prime}$ & $78^{\circ} 00^{\prime} 24^{\prime \prime}$ & Wayne & $\begin{array}{l}\text { Southwest } \\
\text { Goldsboro }\end{array}$ & 4.98 & Neuse River & 03020202 & 2 & 1955 & 1 & 0 \\
\hline 344 & 02089000 & Neuse River near Goldsboro & $35^{\circ} 20^{\prime} 14^{\prime \prime}$ & $77^{\circ} 59^{\prime} 51^{\prime \prime}$ & Wayne & Goldsboro & 2,399 & $\begin{array}{l}\text { Atlantic } \\
\text { Ocean }\end{array}$ & 03020202 & 1 & Feb. 1930 - Sept. 1996 & N/A & $\mathrm{N} / \mathrm{A}$ \\
\hline 345 & 02089020 & Stoney Creek at Goldsboro & $35^{\circ} 22^{\prime} 32^{\prime \prime}$ & $77^{\circ} 57^{\prime} 01 "$ & Wayne & Goldsboro & 21.6 & Neuse River & 03020202 & 2 & $1949-55,1957-58$ & 21 & 0 \\
\hline 346 & 02089034 & Stoney Creek near Goldsboro & $35^{\circ} 20^{\prime} 54^{\prime \prime}$ & $77^{\circ} 58^{\prime} 57^{\prime \prime}$ & Wayne & Goldsboro & 25.4 & Neuse River & 03020202 & 2 & 1955 & 1 & 0 \\
\hline 347 & 02089091 & Sleepy Creek near Dudley & $35^{\circ} 15^{\prime} 06^{\prime \prime}$ & $77^{\circ} 57^{\prime} 13^{\prime \prime}$ & Wayne & Goldsboro & 9.66 & Neuse River & 03020202 & 2 & 1954,1957 & 3 & 0 \\
\hline 348 & 02089116 & Neuse River near Whitehall & $35^{\circ} 15^{\prime} 40^{\prime \prime}$ & $77^{\circ} 54^{\prime} 40^{\prime \prime}$ & Wayne & Goldsboro & 2,471 & $\begin{array}{l}\text { Atlantic } \\
\text { Ocean }\end{array}$ & 03020202 & 2 & $1972-73,1997$ & 10 & 0 \\
\hline 349 & 02089120 & Walnut Creek near Best & $35^{\circ} 18^{\prime} 57^{\prime \prime}$ & $77^{\circ} 53^{\prime} 01^{\prime \prime}$ & Wayne & Goldsboro & 9.71 & Neuse River & 03020202 & 2 & $1955-63$ & 16 & 0 \\
\hline 350 & 02089144 & Walnut Creek near Seven Springs & $35^{\circ} 1654^{\prime \prime}$ & $77^{\circ} 52^{\prime} 08^{\prime \prime}$ & Wayne & La Grange & 18.9 & Neuse River & 03020202 & 2 & $1954-55$ & 2 & 0 \\
\hline 351 & 02089216 & Daileys Creek near Liddell & $35^{\circ} 12^{\prime} 30^{\prime \prime}$ & $77^{\circ} 48 ' 32^{\prime \prime}$ & Lenoir & Seven Springs & 3.80 & $\begin{array}{l}\text { Hardy Mill } \\
\text { Run }\end{array}$ & 03020202 & 1 & Apr. 1978 - Sept. 1981 & N/A & N/A \\
\hline 352 & 02089222 & Bear Creek near Parkstown & $35^{\circ} 22^{\prime} 22^{\prime \prime}$ & $77^{\circ} 48^{\prime} 10^{\prime \prime}$ & Greene & Goldsboro & 4.27 & Neuse River & 03020202 & 1 & Mar. 1978 - Dec. 1982 & N/A & $\mathrm{N} / \mathrm{A}$ \\
\hline 353 & 02089228 & West Bear Creek at New Hope & $35^{\circ} 22^{\prime} 48^{\prime \prime}$ & $77^{\circ} 52^{\prime} 13^{\prime \prime}$ & Wayne & Goldsboro & 13.2 & Bear Creek & 03020202 & 2 & 1957 & 1 & 0 \\
\hline
\end{tabular}


Table 5. Summary of continuous-record gaging stations and partial-record measuring sites in the Neuse River Basin in North Carolina where records of gage height and streamflow were collected-Continued

$\left[\mathrm{mi}^{2}\right.$, square mile; SR, secondary road; N/A, not applicable; SEO, sewage effluent outfall. Sites shaded in gray indicate those sites for which low-flow characteristics have been developed. Period of record for continuous-record sites (site type 1) is shown in months and years; period of record for partial-record sites (site type 2) is shown in water years in which discharge measurements were made]

\begin{tabular}{|c|c|c|c|c|c|c|c|c|c|c|c|c|c|}
\hline \multirow{2}{*}{ 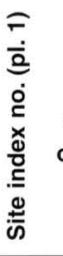 } & \multirow[t]{2}{*}{$\begin{array}{c}\text { USGS } \\
\text { downstream } \\
\text { order number }\end{array}$} & \multirow[t]{2}{*}{ Station name } & \multirow[t]{2}{*}{ Latitude } & \multirow[t]{2}{*}{ Longitude } & \multirow[t]{2}{*}{ County } & \multirow[t]{2}{*}{$\begin{array}{c}\text { USGS } \\
\text { topographic } \\
\text { quadrangle }\end{array}$} & \multirow[t]{2}{*}{$\begin{array}{l}\text { Drainage } \\
\text { area } \\
\left(\mathrm{mi}^{2}\right)\end{array}$} & \multirow[t]{2}{*}{$\begin{array}{l}\text { Tributary } \\
\text { to }\end{array}$} & \multirow[t]{2}{*}{$\begin{array}{l}\text { Hydrologic } \\
\text { unit } \\
\text { code }\end{array}$} & \multirow[t]{2}{*}{$\begin{array}{l}\sum_{2}^{0} \\
\text { के }\end{array}$} & \multirow[t]{2}{*}{ Period of record } & \multicolumn{2}{|c|}{$\begin{array}{c}\text { Number of } \\
\text { measure- } \\
\text { ments for } \\
\text { partial-record } \\
\text { sites }\end{array}$} \\
\hline & & & & & & & & & & & & Flow & $\begin{array}{l}\text { Zero } \\
\text { flow }\end{array}$ \\
\hline 354 & 02089240 & Bear Creek near La Grange & $35^{\circ} 18^{\prime} 51^{\prime \prime}$ & $77^{\circ} 48^{\prime} 56^{\prime \prime}$ & Lenoir & Goldsboro & 49.2 & Neuse River & 03020202 & 2 & $1954-66,1968,1970$ & 23 & 0 \\
\hline 355 & 02089252 & Bear Creek at Mays Store & $35^{\circ} 16^{\prime} 28^{\prime \prime}$ & $77^{\circ} 47^{\prime} 40^{\prime \prime}$ & Lenoir & La Grange & 57.7 & Neuse River & 03020202 & 1 & Oct. 1987 - Sept. 1996 & N/A & N/A \\
\hline 356 & 02089263 & Bear Creek near Mays Store & $35^{\circ} 14^{\prime} 56^{\prime \prime}$ & $77^{\circ} 47^{\prime} 05^{\prime \prime}$ & Lenoir & Seven Springs & 60.0 & Neuse River & 03020201 & 2 & 1954,1957 & 2 & 0 \\
\hline 357 & 02089287 & $\begin{array}{l}\text { Moseley Creek above SEO near La } \\
\text { Grange }\end{array}$ & $35^{\circ} 19^{\prime} 04^{\prime \prime}$ & $77^{\circ} 46^{\prime} 35^{\prime \prime}$ & Lenoir & La Grange & 1.90 & $\begin{array}{l}\text { Falling } \\
\text { Creek }\end{array}$ & 03020202 & 2 & 1973-74 & 5 & 1 \\
\hline 358 & 0208931510 & $\begin{array}{l}\text { Moseley Creek at SR } 1518 \text { near La } \\
\text { Grange }\end{array}$ & $35^{\circ} 18^{\prime} 33^{\prime \prime}$ & $77^{\circ} 45^{\prime} 15^{\prime \prime}$ & Lenoir & Goldsboro & 9.13 & $\begin{array}{l}\text { Falling } \\
\text { Creek }\end{array}$ & 03020202 & 2 & $1973-74$ & 4 & 0 \\
\hline 359 & 02089356 & Gum Swamp near Falling Creek & $35^{\circ} 18^{\prime} 00^{\prime \prime}$ & $77^{\circ} 41^{\prime} 50^{\prime \prime}$ & Lenoir & Kinston & $6.1^{\mathrm{a}}$ & $\begin{array}{l}\text { Falling } \\
\text { Creek }\end{array}$ & 03020201 & 2 & 1957 & 1 & 0 \\
\hline 360 & 02089380 & Falling Creek at Falling Creek & $35^{\circ} 15^{\prime} 40^{\prime \prime}$ & $77^{\circ} 41^{\prime} 30^{\prime \prime}$ & Lenoir & Kinston & 45.4 & Neuse River & 03020201 & 2 & $1949-55,1957,1997$ & 20 & 0 \\
\hline 361 & 02089500 & Neuse River at Kinston & $35^{\circ} 15^{\prime} 29^{\prime \prime}$ & $77^{\circ} 35^{\prime} 09^{\prime \prime}$ & Lenoir & Kinston & 2,692 & $\begin{array}{l}\text { Atlantic } \\
\text { Ocean }\end{array}$ & 03020202 & 1 & Feb. 1930 - Sept. 1996 & N/A & N/A \\
\hline 362 & 02089580 & Deep Run at Deep Run & $35^{\circ} 08^{\prime} 27^{\prime \prime}$ & $77^{\circ} 41^{\prime} 35^{\prime \prime}$ & Lenoir & Deep Run & 6.1 & $\begin{array}{l}\text { Southwest } \\
\text { Creek }\end{array}$ & 03020202 & 2 & $1949-54,1956-57,1966$ & 18 & 0 \\
\hline 363 & 02089620 & Southwest Creek near Woodington & $35^{\circ} 11^{\prime} 25^{\prime \prime}$ & $77^{\circ} 37^{\prime 2} 20^{\prime \prime}$ & Lenoir & Rivermont & 37.7 & Neuse River & 03020202 & 2 & $1956-57,1959-66$ & 16 & 1 \\
\hline 364 & 02089628 & Southwest Creek near Kinston & $35^{\circ} 13^{\prime} 16^{\prime \prime}$ & $77^{\circ} 34^{\prime} 30^{\prime \prime}$ & Lenoir & Deep Run & 49.5 & Neuse River & 03020201 & 2 & $1954-55,1957,1997$ & 4 & 2 \\
\hline 365 & 02089683 & Briery Run near Kinston & $35^{\circ} 18^{\prime} 20^{\prime \prime}$ & $77^{\circ} 36^{\prime} 50^{\prime \prime}$ & Lenoir & Kinston & $4.0^{\mathrm{a}}$ & $\begin{array}{c}\text { Stonyton } \\
\text { Creek }\end{array}$ & 03020201 & 2 & 1955,1957 & 2 & 2 \\
\hline 366 & 02089688 & Stonyton Creek near Harveytown & $35^{\circ} 18^{\prime} 30^{\prime \prime}$ & $77^{\circ} 31^{\prime} 30^{\prime \prime}$ & Lenoir & Kinston & $30^{\mathrm{a}}$ & Neuse River & 03020202 & 2 & $1972-74$ & 5 & 1 \\
\hline 367 & 0208968950 & Jericho Run tributary at Harveytown & $35^{\circ} 17^{\prime} 02^{\prime \prime}$ & $77^{\circ} 33^{\prime} 20^{\prime \prime}$ & Lenoir & Kinston & $0.4^{\mathrm{a}}$ & Jericho Run & 03020202 & 2 & $1972-74$ & 5 & 0 \\
\hline 368 & 02089690 & Stonyton Creek near Graingers & $35^{\circ} 19^{\prime} 05^{\prime \prime}$ & $77^{\circ} 29^{\prime} 44^{\prime \prime}$ & Lenoir & Kinston & $36^{\mathrm{a}}$ & Neuse River & 03020202 & 2 & $\begin{array}{l}\text { 1954, 1956-57, 1965-68, } \\
1970-71\end{array}$ & 14 & 1 \\
\hline 369 & 02089730 & Mosley Creek near Grifton & $35^{\circ} 19^{\prime} 51^{\prime \prime}$ & $77^{\circ} 25^{\prime} 39^{\prime \prime}$ & Lenoir & Grifton & 45.7 & Neuse River & 03020202 & 2 & $\begin{array}{l}\text { 1954-55, 1957, 1964-68, } \\
1971\end{array}$ & 10 & 1 \\
\hline 370 & 02089944 & Moccasin Creek near Pearce Crossroads & $35^{\circ} 53^{\prime} 47^{\prime \prime}$ & $78^{\circ} 18^{\prime} 39^{\prime \prime}$ & Franklin & Bunn West & 8.03 & $\begin{array}{l}\text { Contentnea } \\
\text { Creek }\end{array}$ & 03020203 & 2 & 1969 & 1 & 0 \\
\hline
\end{tabular}




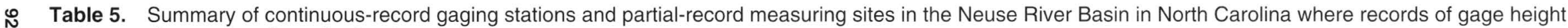
and streamflow were collected-Continued

\begin{tabular}{|c|c|c|c|c|c|c|c|c|c|c|c|c|c|}
\hline \multirow{2}{*}{ 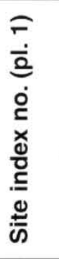 } & \multirow[t]{2}{*}{$\begin{array}{l}\text { USGS } \\
\text { downstream } \\
\text { order number }\end{array}$} & \multirow[t]{2}{*}{ Station name } & \multirow[t]{2}{*}{ Latitude } & \multirow[t]{2}{*}{ Longitude } & \multirow[t]{2}{*}{ County } & \multirow[t]{2}{*}{$\begin{array}{c}\text { USGS } \\
\text { topographic } \\
\text { quadrangle }\end{array}$} & \multirow[t]{2}{*}{$\begin{array}{c}\text { Drainage } \\
\text { area } \\
\left(\mathrm{mi}^{2}\right)\end{array}$} & \multirow[t]{2}{*}{$\begin{array}{l}\text { Tributary } \\
\text { to }\end{array}$} & \multirow[t]{2}{*}{$\begin{array}{l}\text { Hydrologic } \\
\text { unit } \\
\text { code }\end{array}$} & \multirow[t]{2}{*}{$\begin{array}{l}0 \\
\sum_{2}^{0} \\
\vdots \\
\vdots \\
\text { के }\end{array}$} & \multirow[t]{2}{*}{ Period of record } & \multicolumn{2}{|c|}{$\begin{array}{c}\text { Number of } \\
\text { measure- } \\
\text { ments for } \\
\text { partial-record } \\
\text { sites }\end{array}$} \\
\hline & & & & & & & & & & & & Flow & $\begin{array}{l}\text { Zero } \\
\text { flow }\end{array}$ \\
\hline 371 & 02089945 & Moccasin Creek near Pilot & $35^{\circ} 52^{\prime} 16^{\prime \prime}$ & $78^{\circ} 16^{\prime} 56^{\prime \prime}$ & Franklin & Zebulon & $14^{\mathrm{a}}$ & $\begin{array}{l}\text { Contentnea } \\
\text { Creek }\end{array}$ & 03020203 & 2 & 1958,1966 & 2 & 0 \\
\hline 372 & 02089946 & Moccasin Creek near Zebulon & $35^{\circ} 48^{\prime} 48^{\prime \prime}$ & $78^{\circ} 15^{\prime} 27^{\prime \prime}$ & Nash & Zebulon & 29.8 & $\begin{array}{l}\text { Contentnea } \\
\text { Creek }\end{array}$ & 03020203 & 2 & $\begin{array}{l}1950-54,1957-58,1963, \\
1966\end{array}$ & 20 & 1 \\
\hline 373 & 0208995250 & Little Creek at Zebulon & $35^{\circ} 49^{\prime} 00^{\prime \prime}$ & $78^{\circ} 18^{\prime} 07^{\prime \prime}$ & Wake & Zebulon & $1^{\mathrm{a}}$ & $\begin{array}{l}\text { Moccasin } \\
\text { Creek }\end{array}$ & 03020203 & 2 & $1972,1974-75$ & 6 & 1 \\
\hline 374 & 02090000 & Little Creek near Zebulon & $35^{\circ} 48^{\prime} 45^{\prime \prime}$ & $78^{\circ} 16^{\prime} 07^{\prime \prime}$ & Wake & Zebulon & 5.00 & $\begin{array}{l}\text { Moccasin } \\
\text { Creek }\end{array}$ & 03020203 & 2 & $1958,1972,1974-75$ & 8 & 0 \\
\hline 375 & 0209009050 & Moccasin Creek near Middlesex & $35^{\circ} 45^{\prime} 16^{\prime \prime}$ & $78^{\circ} 13^{\prime} 16^{\prime \prime}$ & Nash & Middlesex & 48.7 & $\begin{array}{l}\text { Contentnea } \\
\text { Creek }\end{array}$ & 03020203 & 2 & $1972-74$ & 4 & 0 \\
\hline 376 & 02090144 & Moccasin Creek near Connor & $35^{\circ} 43^{\prime} 48^{\prime \prime}$ & $78^{\circ} 11^{\prime} 23^{\prime \prime}$ & Wilson & $\begin{array}{l}\text { Stancils } \\
\text { Chapel }\end{array}$ & 60.6 & $\begin{array}{l}\text { Contentnea } \\
\text { Creek }\end{array}$ & 03020203 & 2 & 1958 & 1 & 0 \\
\hline 377 & 02090214 & Turkey Creek near Bailey & $35^{\circ} 46^{\prime} 26^{\prime \prime}$ & $78^{\circ} 09^{\prime} 46^{\prime \prime}$ & Nash & Middlesex & 50.9 & $\begin{array}{l}\text { Moccasin } \\
\text { Creek }\end{array}$ & 03020203 & 2 & 1958 & 1 & 0 \\
\hline 378 & 0209024850 & Bailey Branch at Bailey & $35^{\circ} 47^{\prime} 15^{\prime \prime}$ & $78^{\circ} 07^{\prime} 11^{\prime \prime}$ & Nash & Bailey & $1.6^{\mathrm{a}}$ & $\begin{array}{l}\text { Camp } \\
\text { Branch }\end{array}$ & 03020203 & 2 & $1972-74$ & 5 & 1 \\
\hline 379 & 02090249 & Camp Branch near Bailey & $35^{\circ} 46^{\prime} 52^{\prime \prime}$ & $78^{\circ} 07^{\prime} 48^{\prime \prime}$ & Nash & Middlesex & 4.29 & Haw Branch & 03020203 & 2 & 1955 & 1 & 0 \\
\hline 380 & 02090284 & Haw Branch near Bailey & $35^{\circ} 46^{\prime} 30^{\prime \prime}$ & $78^{\circ} 08^{\prime} 41^{\prime \prime}$ & Nash & Middlesex & 7.84 & $\begin{array}{l}\text { Turkey } \\
\text { Creek }\end{array}$ & 03020203 & 2 & $1955,1972-73$ & 5 & 0 \\
\hline 381 & 0209032250 & Cattail Branch at Middlesex & $35^{\circ} 47^{\prime} 07^{\prime \prime}$ & $78^{\circ} 12^{\prime} 28^{\prime \prime}$ & Nash & Middlesex & $0.3^{\mathrm{a}}$ & $\begin{array}{l}\text { Beaverdam } \\
\text { Creek }\end{array}$ & 03020203 & 2 & $1972-75$ & 6 & 3 \\
\hline 382 & 02090323 & Cattail Branch at Middlesex & $35^{\circ} 46^{\prime} 50^{\prime \prime}$ & $78^{\circ} 12^{\prime} 20^{\prime \prime}$ & Nash & Middlesex & 0.61 & $\begin{array}{l}\text { Beaverdam } \\
\text { Creek }\end{array}$ & 03020203 & 2 & $1972-74$ & 4 & 0 \\
\hline 383 & 0209035950 & Turkey Creek near Connor & $35^{\circ} 44^{\prime} 22^{\prime \prime}$ & $78^{\circ} 09^{\prime} 43^{\prime \prime}$ & Wilson & $\begin{array}{l}\text { Stancils } \\
\text { Chapel }\end{array}$ & $73^{\mathrm{a}}$ & $\begin{array}{l}\text { Contentnea } \\
\text { Creek }\end{array}$ & 03020203 & 2 & $1972-73$ & 5 & 1 \\
\hline 384 & 02090360 & Turkey Creek near Connor & $35^{\circ} 43^{\prime} 41^{\prime \prime}$ & $78^{\circ} 10^{\prime} 22^{\prime \prime}$ & Wilson & $\begin{array}{l}\text { Stancils } \\
\text { Chapel }\end{array}$ & 74.2 & $\begin{array}{l}\text { Contentnea } \\
\text { Creek }\end{array}$ & 03020203 & 2 & $1958,1965-68,1971$ & 8 & 0 \\
\hline 385 & 0209036050 & $\begin{array}{l}\text { Contentnea Creek at SR } 1126 \text { near Wilk- } \\
\text { erson Crossroads }\end{array}$ & $35^{\circ} 41^{\prime} 55^{\prime \prime}$ & $78^{\circ} 08^{\prime} 08^{\prime \prime}$ & Wilson & $\begin{array}{l}\text { Stancils } \\
\text { Chapel }\end{array}$ & $140^{\mathrm{a}}$ & Neuse River & 03020203 & 2 & $1974-76$ & 5 & 0 \\
\hline
\end{tabular}


Table 5. Summary of continuous-record gaging stations and partial-record measuring sites in the Neuse River Basin in North Carolina where records of gage height and streamflow were collected-Continued

$\left[\mathrm{mi}^{2}\right.$, square mile; SR, secondary road; N/A, not applicable; SEO, sewage effluent outfall. Sites shaded in gray indicate those sites for which low-flow characteristics have been developed. Period of record for continuous-record sites (site type 1) is shown in months and years; period of record for partial-record sites (site type 2) is shown in water years in which discharge measurements were made]

\begin{tabular}{|c|c|c|c|c|c|c|c|c|c|c|c|c|c|}
\hline \multirow{2}{*}{ 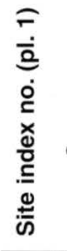 } & \multirow[t]{2}{*}{$\begin{array}{c}\text { USGS } \\
\text { downstream } \\
\text { order number }\end{array}$} & \multirow[t]{2}{*}{ Station name } & \multirow[t]{2}{*}{ Latitude } & \multirow[t]{2}{*}{ Longitude } & \multirow[t]{2}{*}{ County } & \multirow[t]{2}{*}{$\begin{array}{c}\text { USGS } \\
\text { topographic } \\
\text { quadrangle }\end{array}$} & \multirow[t]{2}{*}{$\begin{array}{c}\text { Drainage } \\
\text { area } \\
\left(\mathrm{mi}^{2}\right)\end{array}$} & \multirow[t]{2}{*}{$\begin{array}{l}\text { Tributary } \\
\text { to }\end{array}$} & \multirow[t]{2}{*}{$\begin{array}{c}\text { Hydrologic } \\
\text { unit } \\
\text { code }\end{array}$} & \multirow[t]{2}{*}{$\begin{array}{l}\sum_{2}^{0} \\
\text { के } \\
\text { ì }\end{array}$} & \multirow[t]{2}{*}{ Period of record } & \multicolumn{2}{|c|}{$\begin{array}{l}\text { Number of } \\
\text { measure- } \\
\text { ments for } \\
\text { partial-record } \\
\text { sites }\end{array}$} \\
\hline & & & & & & & & & & & & Flow & $\begin{array}{l}\text { Zero } \\
\text { flow }\end{array}$ \\
\hline 386 & 02090380 & Contentnea Creek near Lucama & $35^{\circ} 41^{\prime} 29^{\prime \prime}$ & $78^{\circ} 06^{\prime} 38^{\prime \prime}$ & Wilson & Lucama & 161 & Neuse River & 03020203 & 1 & Sept. 1964 - Sept. 1996 & N/A & N/A \\
\hline 387 & 02090390 & Contentnea Creek near Kenly & $35^{\circ} 41^{\prime} 10^{\prime \prime}$ & $78^{\circ} 05^{\prime} 45^{\prime \prime}$ & Wilson & Lucama & 169 & Neuse River & 03020203 & 2 & $1957-59,1961-64$ & 13 & 0 \\
\hline 388 & 02090412 & Marsh Swamp at Rock Ridge & $35^{\circ} 42^{\prime} 10^{\prime \prime}$ & $78^{\circ} 03^{\prime} 50^{\prime \prime}$ & Wilson & Lucama & $9.6^{\mathrm{a}}$ & $\begin{array}{l}\text { Contentnea } \\
\text { Creek }\end{array}$ & 03020203 & 2 & 1954,1958 & 2 & 1 \\
\hline 389 & 02090422 & Little Swamp at Rock Ridge & $35^{\circ} 42^{\prime} 07^{\prime \prime}$ & $78^{\circ} 02^{\prime} 57^{\prime \prime}$ & Wilson & Lucama & 3.05 & $\begin{array}{l}\text { Contentnea } \\
\text { Creek }\end{array}$ & 03020203 & 2 & 1954 & 1 & 1 \\
\hline 390 & 02090447 & Mill Branch near Scotts & $35^{\circ} 42^{\prime} 37^{\prime \prime}$ & $78^{\circ} 00^{\prime} 06^{\prime \prime}$ & Wilson & Lucama & 3.66 & $\begin{array}{l}\text { Contentnea } \\
\text { Creek }\end{array}$ & 03020203 & 2 & 1954 & 1 & 1 \\
\hline 391 & 02090452 & Shepard Branch near Scotts & $35^{\circ} 42^{\prime} 42^{\prime \prime}$ & $77^{\circ} 59^{\prime} 46^{\prime \prime}$ & Wilson & Wilson & 4.40 & $\begin{array}{l}\text { Contentnea } \\
\text { Creek }\end{array}$ & 03020203 & 2 & 1954 & 1 & 1 \\
\hline 392 & 02090472 & Bloomery Swamp near Wilson & $35^{\circ} 43^{\prime} 15^{\prime \prime}$ & $77^{\circ} 58^{\prime} 23^{\prime \prime}$ & Wilson & Wilson & 23.2 & $\begin{array}{l}\text { Contentnea } \\
\text { Creek }\end{array}$ & 03020203 & 2 & 1954,1958 & 2 & 1 \\
\hline 393 & 02090500 & Contentnea Creek near Wilson & $35^{\circ} 41^{\prime} 15^{\prime \prime}$ & $77^{\circ} 562^{\prime \prime}$ & Wilson & Wilson & 237 & Neuse River & 03020203 & 1 & Feb. 1930 - Dec. 1954 & N/A & N/A \\
\hline & & & & & & & & & & 2 & 1997 & 1 & 0 \\
\hline 394 & 02090504 & Contentnea Creek near Black Creek & $35^{\circ} 40^{\prime} 08^{\prime \prime}$ & $77^{\circ} 54^{\prime} 38^{\prime \prime}$ & Wilson & Wilson & 243 & Neuse River & 03020203 & 2 & $1969-70$ & 3 & 0 \\
\hline 395 & 02090507 & Hominy Swamp at SR 1321 at Wilson & $35^{\circ} 45^{\prime} 02^{\prime \prime}$ & $77^{\circ} 57^{\prime} 35^{\prime \prime}$ & Wilson & $\begin{array}{l}\text { Winstead } \\
\text { Crossroads }\end{array}$ & $1.5^{\mathrm{a}}$ & $\begin{array}{l}\text { Contentnea } \\
\text { Creek }\end{array}$ & 03020203 & 2 & $1969-70,1972-73$ & 7 & 1 \\
\hline 396 & 02090509 & Hominy Swamp at U.S. 264A at Wilson & $35^{\circ} 44^{\prime} 00^{\prime \prime}$ & $77^{\circ} 55^{\prime} 36^{\prime \prime}$ & Wilson & Wilson & 5.35 & $\begin{array}{l}\text { Contentnea } \\
\text { Creek }\end{array}$ & 03020203 & 2 & $1969-70,1972-73$ & 9 & 2 \\
\hline 397 & 02090512 & $\begin{array}{l}\text { Hominy Swamp at Phillips Street at Wil- } \\
\text { son }\end{array}$ & $35^{\circ} 42^{\prime} 39^{\prime \prime}$ & $77^{\circ} 55^{\prime} 00^{\prime \prime}$ & Wilson & Wilson & 7.92 & $\begin{array}{l}\text { Contentnea } \\
\text { Creek }\end{array}$ & 03020203 & 1 & Aug. 1978 - Sept. 1985 & N/A & N/A \\
\hline 398 & 02090516 & Hominy Swamp near Evansdale & $35^{\circ} 41^{\prime} 32^{\prime \prime}$ & $77^{\circ} 54^{\prime} 22^{\prime \prime}$ & Wilson & Wilson & 9.75 & $\begin{array}{l}\text { Contentnea } \\
\text { Creek }\end{array}$ & 03020203 & 2 & $1969-70,1972-74,1976$ & 10 & 0 \\
\hline 399 & 02090519 & Contentnea Creek near Evansdale & $35^{\circ} 38^{\prime} 34^{\prime \prime}$ & $77^{\circ} 53 \prime 25^{\prime \prime}$ & Wilson & Wilson & 265 & Neuse River & 03020203 & 2 & $1969-70,1972-73$ & 5 & 0 \\
\hline 400 & 0209055995 & Black Creek tributary at Lucama & $35^{\circ} 38^{\prime} 37^{\prime \prime}$ & $78^{\circ} 01^{\prime} 20^{\prime \prime}$ & Wilson & Lucama & 2.5 & Black Creek & 03020203 & 2 & $1972-74,1976,1978$ & 7 & 1 \\
\hline
\end{tabular}




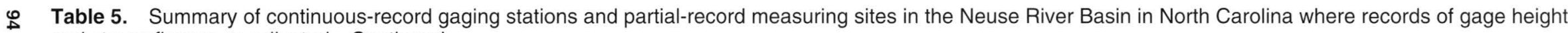
and streamflow were collected-Continued

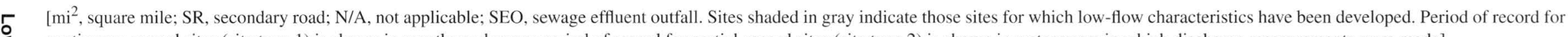
continuous-record sites (site type 1) is shown in months and years; period of record for partial-record sites (site type 2) is shown in water years in which discharge measurements were made]

\begin{tabular}{|c|c|c|c|c|c|c|c|c|c|c|c|c|c|}
\hline 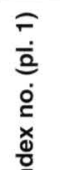 & $\begin{array}{c}\text { USGS } \\
\text { downstream } \\
\text { order number }\end{array}$ & Station name & Latitude & Longitude & County & $\begin{array}{c}\text { USGS } \\
\text { topographic } \\
\text { quadrangle }\end{array}$ & $\begin{array}{c}\text { Drainage } \\
\text { area } \\
\left(\mathrm{mi}^{2}\right)\end{array}$ & $\begin{array}{l}\text { Tributary } \\
\text { to }\end{array}$ & $\begin{array}{l}\text { Hydrologic } \\
\text { unit } \\
\text { code }\end{array}$ & $\sum_{0}^{ \pm}$ & Period of record & $\begin{array}{r}\text { Numb } \\
\text { mea } \\
\text { men } \\
\text { partial- } \\
\text { sit }\end{array}$ & $\begin{array}{l}\text { er of } \\
\text { sure- } \\
\text { s for } \\
\text { record } \\
\text { es }\end{array}$ \\
\hline $\begin{array}{l}= \\
\stackrel{ \pm}{*}\end{array}$ & & & & & & & & & & & & Flow & $\begin{array}{l}\text { Zero } \\
\text { flow }\end{array}$ \\
\hline 401 & 02090560 & Lee Swamp tributary at Lucama & $35^{\circ} 38^{\prime} 22^{\prime \prime}$ & $78^{\circ} 01^{\prime} 39^{\prime \prime}$ & Wilson & Lucama & 2.8 & Lee Swamp & 03020203 & 2 & $\begin{array}{l}\text { 1954, 1958-59, 1961-71, } \\
1993-95\end{array}$ & 17 & 1 \\
\hline 402 & 0209056250 & Lee Swamp near Lucama & $35^{\circ} 38^{\prime} 03^{\prime \prime}$ & $78^{\circ} 01^{\prime} 20^{\prime \prime}$ & Wilson & Lucama & $10^{\mathrm{a}}$ & Black Creek & 03020203 & 2 & $1972-74$ & 5 & 2 \\
\hline 403 & 02090566 & Black Creek near Lucama & $35^{\circ} 37^{\prime} 40^{\prime \prime}$ & $78^{\circ} 00^{\prime} 20^{\prime \prime}$ & Wilson & Lucama & $20^{\mathrm{a}}$ & $\begin{array}{l}\text { Contentnea } \\
\text { Creek }\end{array}$ & 03020203 & 2 & $1956,1972-74$ & 7 & 2 \\
\hline 404 & 0209057190 & Black Creek tributary at Lucama & $35^{\circ} 39^{\prime} 04^{\prime \prime}$ & $77^{\circ} 59^{\prime} 55^{\prime \prime}$ & Wilson & Wilson & $2.9^{\mathrm{a}}$ & Black Creek & 03020203 & 2 & $1972-74$ & 5 & 2 \\
\hline 405 & 02090572 & Black Creek tributary near Lucama & $35^{\circ} 38^{\prime} 36^{\prime \prime}$ & $77^{\circ} 59^{\prime} 15^{\prime \prime}$ & Wilson & Wilson & 5.41 & Black Creek & 03020203 & 2 & 1954,1980 & 2 & 0 \\
\hline 406 & 02090580 & Black Creek near Black Creek & $35^{\circ} 38^{\prime} 16^{\prime \prime}$ & $77^{\circ} 58^{\prime} 19^{\prime \prime}$ & Wilson & Wilson & 32.1 & $\begin{array}{l}\text { Contentnea } \\
\text { Creek }\end{array}$ & 03020203 & 2 & $1955-59,1961-64$ & 17 & 6 \\
\hline 407 & 0209058180 & Black Creek at Black Creek & $35^{\circ} 38^{\prime} 07^{\prime \prime}$ & $77^{\circ} 560^{\prime \prime}$ & Wilson & Wilson & 38.9 & $\begin{array}{l}\text { Contentnea } \\
\text { Creek }\end{array}$ & 03020203 & 2 & $1972-74$ & 5 & 2 \\
\hline 408 & 02090590 & Great Swamp near Black Creek & $35^{\circ} 36^{\prime} 32^{\prime \prime}$ & $77^{\circ} 57^{\prime} 09^{\prime \prime}$ & Wilson & Fremont & 38.8 & Black Creek & 03020203 & 2 & $1958,1965-68,1971$ & 9 & 0 \\
\hline 409 & 02090609 & Aycock Swamp near Fremont & $35^{\circ} 32^{\prime} 19^{\prime \prime}$ & $77^{\circ} 56^{\prime} 03^{\prime \prime}$ & Wayne & Fremont & 3.53 & Black Creek & 03020203 & 2 & $1972-73$ & 4 & 0 \\
\hline 410 & 02090620 & Aycock Swamp near Stantonsburg & $35^{\circ} 35^{\prime} 39^{\prime \prime}$ & $77^{\circ} 53^{\prime} 18^{\prime \prime}$ & Wilson & Fremont & 11.5 & Black Creek & 03020203 & 2 & $1958,1965-68,1971$ & 9 & 0 \\
\hline 411 & 02090625 & Turner Swamp near Eureka & $35^{\circ} 34^{\prime} 14^{\prime \prime}$ & $77^{\circ} 52^{\prime} 47^{\prime \prime}$ & Wayne & Fremont & 2.10 & Black Creek & k 03020203 & 1 & June 1968 - Sept. 1987 & N/A & N/A \\
\hline 412 & 02090629 & $\begin{array}{l}\text { Contentnea Creek at NC } 222 \text { at Stantons- } \\
\text { burg }\end{array}$ & $35^{\circ} 36^{\prime} 08^{\prime \prime}$ & $77^{\circ} 49^{\prime} 53^{\prime \prime}$ & Wilson & Stantonsburg & 386 & Neuse River & 03020203 & 2 & $1969-70,1972-73$ & 7 & 0 \\
\hline 413 & 02090634 & Contentnea Creek near Stantonsburg & $35^{\circ} 35^{\prime} 10^{\prime \prime}$ & $77^{\circ} 48^{\prime} 43^{\prime \prime}$ & Wilson & Stantonsburg & 389 & Neuse River & 03020203 & 2 & $\begin{array}{l}1969-70,1972-74,1978, \\
1980-85,1997\end{array}$ & 33 & 0 \\
\hline 414 & 02090662 & Toisnot Swamp at Stanhope & $35^{\circ} 51^{\prime} 27^{\prime \prime}$ & $78^{\circ} 05^{\prime} 18^{\prime \prime}$ & Nash & Bailey & 6.84 & $\begin{array}{l}\text { Contentnea } \\
\text { Creek }\end{array}$ & 03020203 & 2 & 1958 & 1 & 0 \\
\hline 415 & 02090664 & Toisnot Swamp near Stanhope & $35^{\circ} 50^{\prime} 54^{\prime \prime}$ & $78^{\circ} 03^{\prime} 34^{\prime \prime}$ & Nash & Bailey & 9.97 & $\begin{array}{l}\text { Contentnea } \\
\text { Creek }\end{array}$ & 03020203 & 2 & 1949 & 1 & 0 \\
\hline 416 & 02090674 & Beaverdam Creek near Bailey & $35^{\circ} 47^{\prime} 40^{\prime \prime}$ & $78^{\circ} 04^{\prime} 06^{\prime \prime}$ & Nash & Bailey & 1.50 & $\begin{array}{l}\text { Toisnot } \\
\text { Swamp }\end{array}$ & 03020203 & 2 & 1958 & 1 & 0 \\
\hline
\end{tabular}


Table 5. Summary of continuous-record gaging stations and partial-record measuring sites in the Neuse River Basin in North Carolina where records of gage height and streamflow were collected-Continued

$\left[\mathrm{mi}^{2}\right.$, square mile; SR, secondary road; N/A, not applicable; SEO, sewage effluent outfall. Sites shaded in gray indicate those sites for which low-flow characteristics have been developed. Period of record for continuous-record sites (site type 1) is shown in months and years; period of record for partial-record sites (site type 2) is shown in water years in which discharge measurements were made]

\begin{tabular}{|c|c|c|c|c|c|c|c|c|c|c|c|c|c|}
\hline \multirow{2}{*}{ 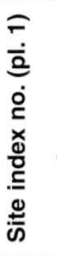 } & \multirow[t]{2}{*}{$\begin{array}{c}\text { USGS } \\
\text { downstream } \\
\text { order number }\end{array}$} & \multirow[t]{2}{*}{ Station name } & \multirow[t]{2}{*}{ Latitude } & \multirow[t]{2}{*}{ Longitude } & \multirow[t]{2}{*}{ County } & \multirow[t]{2}{*}{$\begin{array}{c}\text { USGS } \\
\text { topographic } \\
\text { quadrangle }\end{array}$} & \multirow[t]{2}{*}{$\begin{array}{c}\text { Drainage } \\
\text { area } \\
\left(\mathrm{mi}^{2}\right)\end{array}$} & \multirow[t]{2}{*}{$\begin{array}{l}\text { Tributary } \\
\text { to }\end{array}$} & \multirow[t]{2}{*}{$\begin{array}{c}\text { Hydrologic } \\
\text { unit } \\
\text { code }\end{array}$} & \multirow[t]{2}{*}{ 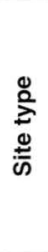 } & \multirow[t]{2}{*}{ Period of record } & \multicolumn{2}{|c|}{$\begin{array}{l}\text { Number of } \\
\text { measure- } \\
\text { ments for } \\
\text { partial-record } \\
\text { sites }\end{array}$} \\
\hline & & & & & & & & & & & & Flow & $\begin{array}{l}\text { Zero } \\
\text { flow }\end{array}$ \\
\hline 417 & 02090720 & Toisnot Swamp near New Hope & $35^{\circ} 49^{\prime} 20^{\prime \prime}$ & $77^{\circ} 59^{\prime} 50^{\prime \prime}$ & Nash & $\begin{array}{l}\text { Winstead } \\
\text { Crossroads }\end{array}$ & $30^{\mathrm{a}}$ & $\begin{array}{l}\text { Contentnea } \\
\text { Creek }\end{array}$ & 03020203 & 2 & $\begin{array}{l}1932,1954,1957-59 \\
1961-64,1969\end{array}$ & 19 & 0 \\
\hline 418 & 02090741 & Toisnot Swamp near Wilson & $35^{\circ} 44^{\prime} 50^{\prime \prime}$ & $77^{\circ} 54^{\prime} 20^{\prime \prime}$ & Wilson & Wilson & $49^{\mathrm{a}}$ & $\begin{array}{l}\text { Contentnea } \\
\text { Creek }\end{array}$ & 03020203 & 2 & 1956 & 3 & 0 \\
\hline 419 & 02090748 & Toisnot Swamp at Wilson & $35^{\circ} 44^{\prime} 02^{\prime \prime}$ & $77^{\circ} 53^{\prime} 24^{\prime \prime}$ & Wilson & Wilson & 56.4 & $\begin{array}{c}\text { Contentnea } \\
\text { Creek }\end{array}$ & 03020203 & 2 & 1933 & 1 & 0 \\
\hline 420 & 02090758 & Toisnot Swamp at U.S. 264 near Wilson & $35^{\circ} 41^{\prime} 50^{\prime \prime}$ & $77^{\circ} 51^{\prime} 18^{\prime \prime}$ & Wilson & Saratoga & 65.2 & $\begin{array}{l}\text { Contentnea } \\
\text { Creek }\end{array}$ & 03020203 & 2 & $1933,1958,1969-70$ & 5 & 0 \\
\hline 421 & 02090780 & Mill Branch near Wilson & $35^{\circ} 42^{\prime} 24^{\prime \prime}$ & $77^{\circ} 47^{\prime} 11^{\prime \prime}$ & Wilson & Saratoga & $2.6^{\mathrm{a}}$ & $\begin{array}{l}\text { Whiteoak } \\
\text { Swamp }\end{array}$ & 03020203 & 2 & $1954-56,1960-71$ & 16 & 1 \\
\hline 422 & 02090796 & Whiteoak Swamp near Drivers Store & $35^{\circ} 41^{\prime} 04^{\prime \prime}$ & $77^{\circ} 48^{\prime} 31^{\prime \prime}$ & Wilson & Saratoga & 25.2 & $\begin{array}{l}\text { Toisnot } \\
\text { Swamp }\end{array}$ & 03020203 & 2 & $1969-70$ & 3 & 0 \\
\hline 423 & 02090805 & Toisnot Swamp near Drivers Store & $35^{\circ} 39^{\prime} 22^{\prime \prime}$ & $77^{\circ} 49^{\prime} 36^{\prime \prime}$ & Wilson & Saratoga & 99.9 & $\begin{array}{l}\text { Contentnea } \\
\text { Creek }\end{array}$ & 03020203 & 2 & $1969-70$ & 4 & 0 \\
\hline 424 & 02090816 & Toisnot Swamp near Saratoga & $35^{\circ} 36^{\prime} 43^{\prime \prime}$ & $77^{\circ} 48^{\prime} 19^{\prime \prime}$ & Wilson & Stantonsburg & 114.7 & $\begin{array}{l}\text { Contentnea } \\
\text { Creek }\end{array}$ & 03020203 & 2 & $1969-70$ & 3 & 0 \\
\hline 425 & 02090820 & Toisnot Swamp near Stantonsburg & $35^{\circ} 35^{\prime} 52^{\prime \prime}$ & $77^{\circ} 47^{\prime} 46^{\prime \prime}$ & Wilson & Stantonsburg & 121.9 & $\begin{array}{l}\text { Contentnea } \\
\text { Creek }\end{array}$ & 03020203 & 2 & $1933,1956-59,1961$ & 10 & 0 \\
\hline 426 & 02090891 & Beamans Run near Walstonburg & $35^{\circ} 32^{\prime} 50^{\prime \prime}$ & $77^{\circ} 44^{\prime} 30^{\prime \prime}$ & Greene & Walstonburg & $7.9^{\mathrm{a}}$ & $\begin{array}{c}\text { Contentnea } \\
\text { Creek }\end{array}$ & 03020203 & 2 & 1957 & 1 & 0 \\
\hline 427 & 02090960 & Nahunta Swamp near Pikeville & $35^{\circ} 30^{\prime} 49^{\prime \prime}$ & $77^{\circ} 58^{\prime} 56^{\prime \prime}$ & Wayne & Fremont & $19^{\mathrm{a}}$ & $\begin{array}{l}\text { Contentnea } \\
\text { Creek }\end{array}$ & 03020203 & 2 & $1957,1961-73$ & 22 & 0 \\
\hline 428 & 0209096845 & The Slough at Pikeville & $35^{\circ} 29^{\prime} 56^{\prime \prime}$ & $77^{\circ} 59^{\prime} 27^{\prime \prime}$ & Wayne & Goldsboro & $0.5^{\mathrm{a}}$ & $\begin{array}{l}\text { Nahunta } \\
\text { Swamp }\end{array}$ & 03020203 & 2 & $1972-75$ & 7 & 3 \\
\hline 429 & 0209096855 & The Slough near Pikeville & $35^{\circ} 28^{\prime} 47^{\prime \prime}$ & $77^{\circ} 57^{\prime} 35^{\prime \prime}$ & Wayne & Goldsboro & 1.84 & $\begin{array}{l}\text { Nahunta } \\
\text { Swamp }\end{array}$ & 03020203 & 2 & 1973-74 & 5 & 2 \\
\hline 430 & 0209096970 & Moccasin Run near Patetown & $35^{\circ} 28^{\prime} 46^{\prime \prime}$ & $77^{\circ} 54^{\prime} 37^{\prime \prime}$ & Wayne & Goldsboro & 1.89 & The Slough & 03020203 & 1 & Apr. 1988 - Sept. 1996 & N/A & N/A \\
\hline 431 & 02090980 & The Slough near Saulston & $35^{\circ} 28^{\prime} 15^{\prime \prime}$ & $77^{\circ} 51^{\prime} 40^{\prime \prime}$ & Wayne & Goldsboro & 21.3 & $\begin{array}{l}\text { Nahunta } \\
\text { Swamp }\end{array}$ & 03020203 & 2 & $1957,1960-66$ & 12 & 0 \\
\hline
\end{tabular}




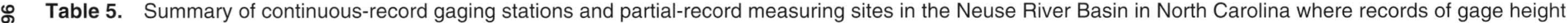
and streamflow were collected-Continued

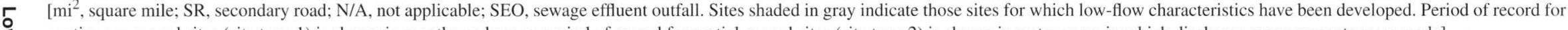
continuous-record sites (site type 1) is shown in months and years; period of record for partial-record sites (site type 2) is shown in water years in which discharge measurements were made]

\begin{tabular}{|c|c|c|c|c|c|c|c|c|c|c|c|c|c|}
\hline \multirow{2}{*}{ 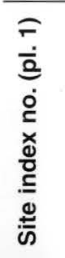 } & \multirow[t]{2}{*}{$\begin{array}{l}\text { USGS } \\
\text { downstream } \\
\text { order number }\end{array}$} & \multirow[t]{2}{*}{ Station name } & \multirow[t]{2}{*}{ Latitude } & \multirow[t]{2}{*}{ Longitude } & \multirow[t]{2}{*}{ County } & \multirow[t]{2}{*}{$\begin{array}{c}\text { USGS } \\
\text { topographic } \\
\text { quadrangle }\end{array}$} & \multirow[t]{2}{*}{$\begin{array}{l}\text { Drainage } \\
\text { area } \\
\left(\mathrm{mi}^{2}\right)\end{array}$} & \multirow[t]{2}{*}{$\begin{array}{l}\text { Tributary } \\
\text { to }\end{array}$} & \multirow[t]{2}{*}{$\begin{array}{l}\text { Hydrologic } \\
\text { unit } \\
\text { code }\end{array}$} & \multirow[t]{2}{*}{$\begin{array}{l}\sum_{2}^{0} \\
\text { i⿱ } \\
\text { is }\end{array}$} & \multirow[t]{2}{*}{ Period of record } & \multicolumn{2}{|c|}{$\begin{array}{l}\text { Number of } \\
\text { measure- } \\
\text { ments for } \\
\text { partial-record } \\
\text { sites }\end{array}$} \\
\hline & & & & & & & & & & & & Flow & $\begin{array}{l}\text { Zero } \\
\text { flow }\end{array}$ \\
\hline 432 & 02091000 & Nahunta Swamp near Shine & $35^{\circ} 29^{\prime} 20^{\prime \prime}$ & $77^{\circ} 48^{\prime} 22^{\prime \prime}$ & Greene & Jason & 80.4 & $\begin{array}{l}\text { Contentnea } \\
\text { Creek }\end{array}$ & 03020203 & 1 & Apr. 1954 - Sept. 1996 & N/A & $\mathrm{N} / \mathrm{A}$ \\
\hline 433 & 02091040 & Nahunta Swamp near Snow Hill & $35^{\circ} 30^{\prime} 30^{\prime \prime}$ & $77^{\circ} 44^{\prime} 20^{\prime \prime}$ & Greene & Walstonburg & $90^{\mathrm{a}}$ & $\begin{array}{l}\text { Contentnea } \\
\text { Creek }\end{array}$ & 03020203 & 2 & $1949-54,1957,1967-68$ & 20 & 0 \\
\hline 434 & 02091141 & Fort Run near Contentnea & $35^{\circ} 29^{\prime} 50^{\prime \prime}$ & $77^{\circ} 43^{\prime} 30^{\prime \prime}$ & Greene & Snow Hill & $10^{\mathrm{a}}$ & $\begin{array}{l}\text { Contentnea } \\
\text { Creek }\end{array}$ & 03020203 & 2 & 1954,1957 & 2 & 0 \\
\hline 435 & 02091241 & $\begin{array}{l}\text { Contentnea Creek at U.S. } 258 \text { at Snow } \\
\text { Hill }\end{array}$ & $35^{\circ} 27^{\prime} 27^{\prime \prime}$ & $77^{\circ} 40^{\prime} 11^{\prime \prime}$ & Greene & Snow Hill & 694 & Neuse River & 03020203 & 2 & $\begin{array}{l}\text { 1969-70, 1972-74, 1978, } \\
\text { 1980, 1997 }\end{array}$ & 11 & 0 \\
\hline 436 & 02091430 & Shepherd Run near Snow Hill & $35^{\circ} 26^{\prime} 06^{\prime \prime}$ & $77^{\circ} 38^{\prime} 42^{\prime \prime}$ & Greene & Snow Hill & 1.47 & $\begin{array}{l}\text { Contentnea } \\
\text { Creek }\end{array}$ & 03020203 & 2 & $1953,1955,1957-73$ & 27 & 0 \\
\hline 437 & 02091480 & Rainbow Creek near Glenfield & $35^{\circ} 24^{\prime} 30^{\prime \prime}$ & $77^{\circ} 37^{\prime} 20^{\prime \prime}$ & Greene & Hookerton & $12^{\mathrm{a}}$ & $\begin{array}{l}\text { Contentnea } \\
\text { Creek }\end{array}$ & 03020203 & 2 & $1960-65$ & 8 & 0 \\
\hline 438 & 02091486 & Rainbow Creek at Hookerton & $35^{\circ} 25^{\prime} 30^{\prime \prime}$ & $77^{\circ} 35^{\prime} 40^{\prime \prime}$ & Greene & Hookerton & $15^{\mathrm{a}}$ & $\begin{array}{l}\text { Contentnea } \\
\text { Creek }\end{array}$ & 03020203 & 2 & $1954-57$ & 5 & 0 \\
\hline 439 & 02091500 & Contentnea Creek at Hookerton & $35^{\circ} 25^{\prime} 44^{\prime \prime}$ & $77^{\circ} 34^{\prime} 59^{\prime \prime}$ & Greene & Hookerton & 733 & Neuse River & 03020203 & 1 & Nov. 1928 - Sept. 1996 & N/A & N/A \\
\hline 440 & 02091529 & Mussel Run near Hookerton & $35^{\circ} 26^{\prime} 20^{\prime \prime}$ & $77^{\circ} 34^{\prime} 00^{\prime \prime}$ & Greene & Hookerton & $11^{\mathrm{a}}$ & $\begin{array}{l}\text { Contentnea } \\
\text { Creek }\end{array}$ & 03020203 & 2 & $1955-57$ & 3 & 0 \\
\hline 441 & 02091544 & Wheat Swamp near Hugo & $35^{\circ} 23^{\prime} 10^{\prime \prime}$ & $77^{\circ} 33^{\prime} 57^{\prime \prime}$ & Greene & Hookerton & 20.5 & $\begin{array}{l}\text { Contentnea } \\
\text { Creek }\end{array}$ & 03020203 & 2 & $1956-57$ & 4 & 1 \\
\hline 442 & 02091559 & Polecat Branch near Hookerton & $35^{\circ} 26^{\prime} 00^{\prime \prime}$ & $77^{\circ} 32^{\prime} 40^{\prime \prime}$ & Greene & Hookerton & $3.2^{\mathrm{a}}$ & $\begin{array}{l}\text { Contentnea } \\
\text { Creek }\end{array}$ & 03020203 & 2 & $1954-55,1957$ & 3 & 0 \\
\hline 443 & 02091574 & Contentnea Creek near Hugo & $35^{\circ} 24^{\prime} 46^{\prime \prime}$ & $77^{\circ} 29^{\prime} 51^{\prime \prime}$ & Lenoir & Ayden & 789 & Neuse River & 03020203 & 2 & $\begin{array}{l}1956-57,1969-70,1973- \\
74,1997\end{array}$ & 11 & 0 \\
\hline 444 & 02091589 & $\begin{array}{l}\text { Little Contentnea Creek tributary near } \\
\text { Walstonburg }\end{array}$ & $35^{\circ} 36^{\prime} 20^{\prime \prime}$ & $77^{\circ} 40^{\prime} 40^{\prime \prime}$ & Greene & Walstonburg & $3.0^{\mathrm{a}}$ & $\begin{array}{l}\text { Little Con- } \\
\text { tentnea } \\
\text { Creek }\end{array}$ & 03020203 & 2 & $1972-74$ & 4 & 1 \\
\hline 445 & 02091604 & Little Contentnea Creek near Fountain & $35^{\circ} 36^{\prime} 42^{\prime \prime}$ & $77^{\circ} 37^{\prime} 00^{\prime \prime}$ & Pitt & Farmville & $36^{\mathrm{a}}$ & $\begin{array}{l}\text { Contentnea } \\
\text { Creek }\end{array}$ & 03020203 & 2 & $1956-57$ & 4 & 0 \\
\hline
\end{tabular}


Table 5. Summary of continuous-record gaging stations and partial-record measuring sites in the Neuse River Basin in North Carolina where records of gage height and streamflow were collected-Continued

$\left[\mathrm{mi}^{2}\right.$, square mile; SR, secondary road; N/A, not applicable; SEO, sewage effluent outfall. Sites shaded in gray indicate those sites for which low-flow characteristics have been developed. Period of record for continuous-record sites (site type 1) is shown in months and years; period of record for partial-record sites (site type 2) is shown in water years in which discharge measurements were made]

\begin{tabular}{|c|c|c|c|c|c|c|c|c|c|c|c|c|c|}
\hline \multirow{2}{*}{ 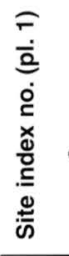 } & \multirow[t]{2}{*}{$\begin{array}{l}\text { USGS } \\
\text { downstream } \\
\text { order number }\end{array}$} & \multirow[t]{2}{*}{ Station name } & \multirow[t]{2}{*}{ Latitude } & \multirow[t]{2}{*}{ Longitude } & \multirow[t]{2}{*}{ County } & \multirow[t]{2}{*}{$\begin{array}{l}\text { USGS } \\
\text { topographic } \\
\text { quadrangle }\end{array}$} & \multirow[t]{2}{*}{$\begin{array}{l}\text { Drainage } \\
\text { area } \\
\left(\mathrm{mi}^{2}\right)\end{array}$} & \multirow[t]{2}{*}{$\begin{array}{l}\text { Tributary } \\
\text { to }\end{array}$} & \multirow[t]{2}{*}{$\begin{array}{l}\text { Hydrologic } \\
\text { unit } \\
\text { code }\end{array}$} & \multirow[t]{2}{*}{ 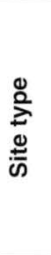 } & \multirow[t]{2}{*}{ Period of record } & \multicolumn{2}{|c|}{$\begin{array}{l}\text { Number of } \\
\text { measure- } \\
\text { ments for } \\
\text { partial-record } \\
\text { sites }\end{array}$} \\
\hline & & & & & & & & & & & & Flow & $\begin{array}{l}\text { Zero } \\
\text { flow }\end{array}$ \\
\hline 446 & 02091618 & Langs Mill Run at NC 222 at Fountain & $35^{\circ} 40^{\prime} 18^{\prime \prime}$ & $77^{\circ} 38^{\prime} 50^{\prime \prime}$ & Pitt & Fountain & $3.1^{\mathrm{a}}$ & $\begin{array}{l}\text { Black } \\
\text { Swamp }\end{array}$ & 03020203 & 2 & $1974-75$ & 3 & 0 \\
\hline 447 & 02091619 & Langs Mill Run at Fountain & $35^{\circ} 39^{\prime} 50^{\prime \prime}$ & $77^{\circ} 38^{\prime} 00^{\prime \prime}$ & Pitt & Fountain & $4.6^{\mathrm{a}}$ & $\begin{array}{l}\text { Black } \\
\text { Swamp }\end{array}$ & 03020203 & 2 & 1973-75 & 4 & 1 \\
\hline 448 & 02091634 & Black Swamp near Farmville & $35^{\circ} 37^{\prime} 30^{\prime \prime}$ & $77^{\circ} 35^{\prime} 30^{\prime \prime}$ & Pitt & Farmville & $12^{\mathrm{a}}$ & $\begin{array}{l}\text { Little Con- } \\
\text { tentnea } \\
\text { Creek }\end{array}$ & 03020203 & 2 & 1957 & 1 & 1 \\
\hline 449 & 02091664 & $\begin{array}{l}\text { Little Contentnea Creek at NC } 121 \text { near } \\
\text { Farmville }\end{array}$ & $35^{\circ} 36^{\prime} 19^{\prime \prime}$ & $77^{\circ} 34^{\prime} 27^{\prime \prime}$ & Pitt & Farmville & 55.1 & $\begin{array}{l}\text { Contentnea } \\
\text { Creek }\end{array}$ & 03020203 & 2 & $\begin{array}{l}1956,1969-70,1972, \\
1974\end{array}$ & 10 & 0 \\
\hline 450 & 02091679 & Little Contentnea Creek near Bell Arthur & $35^{\circ} 35^{\prime} 08^{\prime \prime}$ & $77^{\circ} 32^{\prime} 28^{\prime \prime}$ & Pitt & Farmville & 64.3 & $\begin{array}{l}\text { Contentnea } \\
\text { Creek }\end{array}$ & 03020203 & 2 & 1969-70, 1972, 1974 & 5 & 0 \\
\hline 451 & 02091700 & Little Contentnea Creek near Farmville & $35^{\circ} 32^{\prime} 40^{\prime \prime}$ & $77^{\circ} 30^{\prime} 41^{\prime \prime}$ & Pitt & Farmville & 93.3 & $\begin{array}{l}\text { Contentnea } \\
\text { Creek }\end{array}$ & 03020203 & 1 & Oct. 1956 - Sept. 1987 & N/A & N/A \\
\hline & & & & & & & & & & 2 & $1952-54,1956$ & 8 & 0 \\
\hline 452 & 02091712 & Middle Swamp near Marlboro & $35^{\circ} 33^{\prime} 54^{\prime \prime}$ & $77^{\circ} 35^{\prime} 45^{\prime \prime}$ & Pitt & Farmville & $14^{\mathrm{a}}$ & $\begin{array}{c}\text { Little Con- } \\
\text { tentnea } \\
\text { Creek }\end{array}$ & 03020203 & 2 & $1972-74$ & 3 & 0 \\
\hline 453 & 02091716 & Middle Swamp near Lizzie & $35^{\circ} 32^{\prime} 36^{\prime \prime}$ & $77^{\circ} 34^{\prime} 01^{\prime \prime}$ & Greene & Farmville & $20^{\mathrm{a}}$ & $\begin{array}{l}\text { Little Con- } \\
\text { tentnea } \\
\text { Creek }\end{array}$ & 03020203 & 2 & 1954,1957 & 2 & 2 \\
\hline 454 & 02091732 & Sandy Run near Lizzie & $35^{\circ} 31^{\prime} 53^{\prime \prime}$ & $77^{\circ} 33^{\prime} 32^{\prime \prime}$ & Greene & Farmville & $29^{\mathrm{a}}$ & $\begin{array}{l}\text { Middle } \\
\quad \text { Swamp }\end{array}$ & 03020203 & 2 & 1954,1957 & 2 & 2 \\
\hline 455 & 02091737 & $\begin{array}{l}\text { Little Contentnea Creek near Willow } \\
\text { Green }\end{array}$ & $35^{\circ} 31^{\prime} 30^{\prime \prime}$ & $77^{\circ} 31^{\prime} 15^{\prime \prime}$ & Greene & Farmville & $145^{\mathrm{a}}$ & $\begin{array}{l}\text { Contentnea } \\
\text { Creek }\end{array}$ & 03020203 & 2 & $1969-70$ & 3 & 0 \\
\hline 456 & 02091740 & Little Contentnea Creek at Scuffleton & $35^{\circ} 27^{\prime} 24^{\prime \prime}$ & $77^{\circ} 29^{\prime} 09^{\prime \prime}$ & Pitt & Ayden & 172 & $\begin{array}{l}\text { Contentnea } \\
\text { Creek }\end{array}$ & 03020203 & 2 & $\begin{array}{l}1956-57,1965-66,1969 \\
70,1980,1997\end{array}$ & 15 & 0 \\
\hline 457 & 02091764 & Contentnea Creek at Grifton & $35^{\circ} 22^{\prime} 12^{\prime \prime}$ & $77^{\circ} 26^{\prime} 47^{\prime \prime}$ & Pitt & Grifton & $980^{\mathrm{a}}$ & Neuse River & 03020203 & 2 & 1969-70, 1972 & 6 & 0 \\
\hline 458 & 02091786 & Eagle Swamp near Grifton & $35^{\circ} 21^{\prime} 40^{\prime \prime}$ & $77^{\circ} 26^{\prime} 30^{\prime \prime}$ & Lenoir & Grifton & $9.7^{\mathrm{a}}$ & $\begin{array}{l}\text { Contentnea } \\
\text { Creek }\end{array}$ & 03020203 & 2 & $1954-55,1957$ & 3 & 0 \\
\hline
\end{tabular}




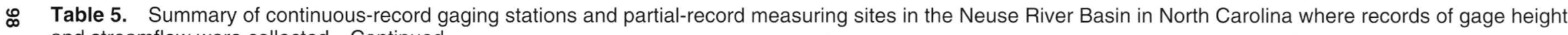
and streamflow were collected-Continued

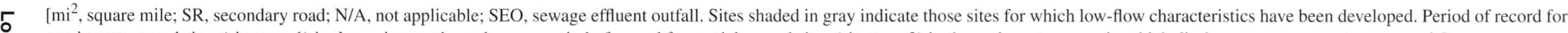
continuous-record sites (site type 1) is shown in months and years; period of record for partial-record sites (site type 2) is shown in water years in which discharge measurements were made]

\begin{tabular}{|c|c|c|c|c|c|c|c|c|c|c|c|c|c|}
\hline 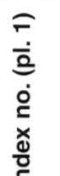 & $\begin{array}{c}\text { USGS } \\
\text { downstream } \\
\text { order number }\end{array}$ & Station name & Latitude & Longitude & County & $\begin{array}{c}\text { USGS } \\
\text { topographic } \\
\text { quadrangle }\end{array}$ & $\begin{array}{l}\text { Drainage } \\
\text { area } \\
\left(\mathrm{mi}^{2}\right)\end{array}$ & $\begin{array}{l}\text { Tributary } \\
\text { to }\end{array}$ & $\begin{array}{c}\text { Hydrologic } \\
\text { unit } \\
\text { code }\end{array}$ & 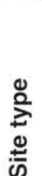 & Period of record & $\begin{array}{r}\text { Num } \\
\text { mea } \\
\text { men } \\
\text { partial } \\
\text { si }\end{array}$ & $\begin{array}{l}\text { ur of } \\
\text { ure- } \\
\text { s for } \\
\text { record } \\
\text { es }\end{array}$ \\
\hline 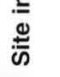 & & & & & & & & & & & & Flow & $\begin{array}{l}\text { Zero } \\
\text { flow }\end{array}$ \\
\hline 459 & 02091810 & Halfmoon Creek near Fort Barnwell & $35^{\circ} 17^{\prime} 58^{\prime \prime}$ & $77^{\circ} 21^{\prime} 14^{\prime \prime}$ & Craven & Fort Barnwell & $4.9^{\mathrm{a}}$ & Neuse River & 03020202 & 2 & $1961-76$ & 16 & 0 \\
\hline 460 & 02091814 & Neuse River near Fort Barnwell & $35^{\circ} 18^{\prime} 40^{\prime \prime}$ & $77^{\circ} 18^{\prime} 20^{\prime \prime}$ & Craven & Fort Barnwell & $3,900^{\mathrm{a}}$ & $\begin{array}{l}\text { Atlantic } \\
\text { Ocean }\end{array}$ & 03020202 & 2 & $\begin{array}{l}1970,1972-73,1976, \\
1978,1980-82,1985-91 \\
1995-96,1997\end{array}$ & 31 & 0 \\
\hline 461 & 02091820 & Core Creek near Fort Barnwell & $35^{\circ} 15^{\prime} 10^{\prime \prime}$ & $77^{\circ} 17^{\prime} 10^{\prime \prime}$ & Craven & Fort Barnwell & $59^{\mathrm{a}}$ & Neuse River & 03020201 & 2 & $1949-58$ & 22 & 0 \\
\hline 462 & 02091824 & Core Creek tributary near Fort Barnwell & $35^{\circ} 16^{\prime} 40^{\prime \prime}$ & $77^{\circ} 18^{\prime} 10^{\prime \prime}$ & Craven & Fort Barnwell & $8.1^{\mathrm{a}}$ & Neuse River & 03020201 & 2 & 1954,1957 & 2 & 1 \\
\hline 463 & 0209184590 & Swift Creek at SR 1126 at Winterville & $35^{\circ} 32^{\prime} 16^{\prime \prime}$ & $77^{\circ} 25^{\prime} 07^{\prime \prime}$ & Pitt & Greenville SW & $7.6^{\mathrm{a}}$ & Neuse River & 03020202 & 2 & $\begin{array}{l}1974-76,1978,1980, \\
1997\end{array}$ & 8 & 0 \\
\hline 464 & 02091849 & Swift Creek near Winterville & $35^{\circ} 31^{\prime} 40^{\prime \prime}$ & $77^{\circ} 25^{\prime} 30^{\prime \prime}$ & Pitt & Greenville SW & $9.5^{\mathrm{a}}$ & Neuse River & 03020202 & 2 & $1956,1973-75$ & 6 & 0 \\
\hline 465 & 02091859 & Swift Creek at NC 102 near Ayden & $35^{\circ} 28^{\prime} 10^{\prime \prime}$ & $77^{\circ} 24^{\prime} 00^{\prime \prime}$ & Pitt & Ayden & $25^{\mathrm{a}}$ & Neuse River & 03020202 & 2 & $1956-57,1974-75,1997$ & 9 & 1 \\
\hline 466 & 02091874 & Fork Swamp near Ayden & $35^{\circ} 29^{\prime} 20^{\prime \prime}$ & $77^{\circ} 22^{\prime} 00^{\prime \prime}$ & Pitt & Gardnerville & $17^{\mathrm{a}}$ & Swift Creek & 03020202 & 2 & 1957 & 1 & 1 \\
\hline 467 & 0209187450 & Fork Swamp at NC Hwy 102 near Ayden & $35^{\circ} 28^{\prime} 11^{\prime \prime}$ & $77^{\circ} 21^{\prime} 23^{\prime \prime}$ & Pitt & Gardnerville & $21^{\mathrm{a}}$ & Swift Creek & 03020202 & 2 & $1973-75$ & 4 & 1 \\
\hline 468 & 02091910 & Swift Creek near Coxville & $35^{\circ} 24^{\prime} 07^{\prime \prime}$ & $77^{\circ} 19^{\prime} 54^{\prime \prime}$ & Pitt & Gardnerville & 78.2 & Neuse River & 03020202 & 2 & $\begin{array}{l}1956-57,1960-70,1974- \\
75,1997\end{array}$ & 28 & 0 \\
\hline 469 & 02091954 & Clayroot Swamp near Gardnerville & $35^{\circ} 23^{\prime} 32^{\prime \prime}$ & $77^{\circ} 15^{\prime} 49^{\prime \prime}$ & Pitt & Gardnerville & $46^{\mathrm{a}}$ & Swift Creek & 03020202 & 2 & 1957 & 1 & 1 \\
\hline 470 & 02091960 & Creeping Swamp near Calico & $35^{\circ} 25^{\prime} 46^{\prime \prime}$ & $77^{\circ} 11^{\prime} 12^{\prime \prime}$ & Beaufort & Wilmar & 9.8 & $\begin{array}{l}\text { Clayroot } \\
\text { Swamp }\end{array}$ & 03020202 & 1 & Mar. 1971 - Mar. 1977 & N/A & N/A \\
\hline & & & & & & & & & & 2 & 1971 & 1 & 0 \\
\hline 471 & 02091970 & Creeping Swamp near Vanceboro & $35^{\circ} 23^{\prime} 30^{\prime \prime}$ & $77^{\circ} 13^{\prime} 46^{\prime \prime}$ & Craven & Wilmar & $27^{\mathrm{a}}$ & $\begin{array}{l}\text { Clayroot } \\
\text { Swamp }\end{array}$ & 03020202 & 1 & Mar. 1971 - Sept. 1985 & N/A & N/A \\
\hline & & & & & & & & & & 2 & 1971 & 1 & 1 \\
\hline 472 & 02092000 & Swift Creek near Vanceboro & $35^{\circ} 20^{\prime} 42^{\prime \prime}$ & $77^{\circ} 11^{\prime} 45^{\prime \prime}$ & Craven & Vanceboro & 182 & Neuse River & 03020202 & 1 & Jan. 1950 - Sept. 1989 & N/A & N/A \\
\hline 473 & 02092015 & Fork Swamp at Wilmar & $35^{\circ} 22^{\prime} 59^{\prime \prime}$ & $77^{\circ} 07^{\prime} 08^{\prime \prime}$ & Beaufort & Hackney & $4.5^{\mathrm{a}}$ & $\begin{array}{l}\text { Palmetto } \\
\text { Swamp }\end{array}$ & 03020202 & 2 & 1970 & 1 & 1 \\
\hline
\end{tabular}


Table 5. Summary of continuous-record gaging stations and partial-record measuring sites in the Neuse River Basin in North Carolina where records of gage height and streamflow were collected-Continued

$\left[\mathrm{mi}^{2}\right.$, square mile; SR, secondary road; N/A, not applicable; SEO, sewage effluent outfall. Sites shaded in gray indicate those sites for which low-flow characteristics have been developed. Period of record for continuous-record sites (site type 1) is shown in months and years; period of record for partial-record sites (site type 2) is shown in water years in which discharge measurements were made]

\begin{tabular}{|c|c|c|c|c|c|c|c|c|c|c|c|c|c|}
\hline \multirow{2}{*}{ 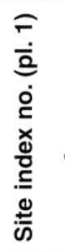 } & \multirow[t]{2}{*}{$\begin{array}{c}\text { USGS } \\
\text { downstream } \\
\text { order number }\end{array}$} & \multirow[t]{2}{*}{ Station name } & \multirow[t]{2}{*}{ Latitude } & \multirow[t]{2}{*}{ Longitude } & \multirow[t]{2}{*}{ County } & \multirow[t]{2}{*}{$\begin{array}{c}\text { USGS } \\
\text { topographic } \\
\text { quadrangle }\end{array}$} & \multirow[t]{2}{*}{$\begin{array}{c}\text { Drainage } \\
\text { area } \\
\left(\mathrm{mi}^{2}\right)\end{array}$} & \multirow[t]{2}{*}{$\begin{array}{l}\text { Tributary } \\
\text { to }\end{array}$} & \multirow[t]{2}{*}{$\begin{array}{l}\text { Hydrologic } \\
\text { unit } \\
\text { code }\end{array}$} & \multirow[t]{2}{*}{$\begin{array}{l}\stackrel{ \pm}{2} \\
\stackrel{ \pm}{\infty}\end{array}$} & \multirow[t]{2}{*}{ Period of record } & \multicolumn{2}{|c|}{$\begin{array}{l}\text { Number of } \\
\text { measure- } \\
\text { ments for } \\
\text { partial-record } \\
\text { sites }\end{array}$} \\
\hline & & & & & & & & & & & & Flow & $\begin{array}{l}\text { Zero } \\
\text { flow }\end{array}$ \\
\hline 474 & 02092018 & $\begin{array}{l}\text { Palmetto Swamp at U.S. } 17 \text { near Vance- } \\
\text { boro }\end{array}$ & $35^{\circ} 21^{\prime} 40^{\prime \prime}$ & $77^{\circ} 08^{\prime} 50^{\prime \prime}$ & Craven & Vanceboro & $16^{\mathrm{a}}$ & Swift Creek & 03020202 & 2 & $1970-71$ & 2 & 2 \\
\hline 475 & 02092020 & Palmetto Swamp near Vanceboro & $35^{\circ} 20^{\prime} 18^{\prime \prime}$ & $77^{\circ} 10^{\prime} 16^{\prime \prime}$ & Craven & Vanceboro & 24.2 & Swift Creek & 03020202 & 1 & Mar. 1971 - Sept. 1976 & N/A & N/A \\
\hline & & & & & & & & & & 2 & 1956-71 & 34 & 4 \\
\hline 476 & 02092040 & Poplar Branch near Vanceboro & $35^{\circ} 16^{\prime} 13^{\prime \prime}$ & $77^{\circ} 08^{\prime} 55^{\prime \prime}$ & Craven & Vanceboro & $3.6^{\mathrm{a}}$ & Swift Creek & 03020202 & 2 & $1957,1964-68,1970-71$ & 9 & 1 \\
\hline 477 & 0209205053 & Swift Creek at NC 43 near Streets Ferry & $35^{\circ} 13^{\prime} 56^{\prime \prime}$ & $77^{\circ} 06^{\prime} 52^{\prime \prime}$ & Craven & Askin & 269 & Neuse River & 03020202 & 1 & July 1996 - Sept. 1996 & N/A & N/A \\
\hline 478 & 02092052 & Little Swift Creek near Cayton & $35^{\circ} 15^{\prime} 10^{\prime \prime}$ & $77^{\circ} 00^{\prime} 10^{\prime \prime}$ & Craven & Ernul & $26^{\mathrm{a}}$ & Swift Creek & 03020202 & 2 & 1957 & 1 & 0 \\
\hline 479 & 02092061 & Pine Tree Swamp near Cayton & $35^{\circ} 15^{\prime} 00^{\prime \prime}$ & $77^{\circ} 00^{\prime} 00^{\prime \prime}$ & Craven & Askin & $1.8^{\mathrm{a}}$ & $\begin{array}{l}\text { Little Swift } \\
\text { Creek }\end{array}$ & 03020202 & 2 & 1957 & 1 & 1 \\
\hline 480 & 02092069 & Little Swift Creek tributary near Askin & $35^{\circ} 14^{\prime} 00^{\prime \prime}$ & $77^{\circ} 02^{\prime} 20^{\prime \prime}$ & Craven & Askin & 1.23 & $\begin{array}{l}\text { Little Swift } \\
\text { Creek }\end{array}$ & 03020202 & 2 & 1957 & 1 & 1 \\
\hline 481 & 02092120 & Bachelor Creek near New Bern & $35^{\circ} 09^{\prime} 00^{\prime \prime}$ & $77^{\circ} 10^{\prime} 20^{\prime \prime}$ & Craven & Jasper & 32.4 & Neuse River & 03020202 & 2 & $1942,1956-57,1960-71$ & 18 & 0 \\
\hline 482 & 0209213705 & Mills Branch at SR 1431 near Bridgeton & $35^{\circ} 09^{\prime} 04^{\prime \prime}$ & $77^{\circ} 02^{\prime} 09^{\prime \prime}$ & Craven & Askin & $0.8^{\mathrm{a}}$ & Neuse River & 03020204 & 2 & 1973 & 1 & 1 \\
\hline 483 & 0209213765 & $\begin{array}{l}\text { Mills Branch tributary No.1 at U.S. High- } \\
\text { way } 17 \text { near Bridgeton }\end{array}$ & $35^{\circ} 08^{\prime} 59^{\prime \prime}$ & $77^{\circ} 01^{\prime} 38^{\prime \prime}$ & Craven & Askin & $1.6^{\mathrm{a}}$ & $\begin{array}{l}\text { Mills } \\
\text { Branch }\end{array}$ & 03020204 & 2 & 1973 & 1 & 0 \\
\hline 484 & 02092141 & $\begin{array}{l}\text { Jack Smith Creek tributary at Tryon Street } \\
\text { at New Bern }\end{array}$ & $35^{\circ} 06^{\prime} 31^{\prime \prime}$ & $77^{\circ} 04^{\prime} 04^{\prime \prime}$ & Craven & New Bern & $1^{\mathrm{a}}$ & $\begin{array}{l}\text { Jack Smith } \\
\text { Creek }\end{array}$ & 03020204 & 2 & 1956 & 2 & 2 \\
\hline 485 & 02092162 & Neuse River at New Bern & $35^{\circ} 06^{\prime} 33^{\prime \prime}$ & $77^{\circ} 01^{\prime} 59^{\prime \prime}$ & Craven & New Bern & 4,467 & $\begin{array}{l}\text { Atlantic } \\
\text { Ocean }\end{array}$ & 03020204 & 1 & $\begin{array}{l}\text { (gage height only) } \\
\text { Mar. } 1988 \text { - Sept. } 1996\end{array}$ & N/A & N/A \\
\hline 486 & 0209218190 & Trent River at NC 11 near Deep Run & $35^{\circ} 06^{\prime} 23^{\prime \prime}$ & $77^{\circ} 43^{\prime} 15^{\prime \prime}$ & Lenoir & Deep Run & $3.2^{\mathrm{a}}$ & Neuse River & 03020204 & 2 & $1974-76,1980-84$ & 34 & 1 \\
\hline 487 & 02092186 & Trent River near Woodington & $35^{\circ} 05^{\prime} 47^{\prime \prime}$ & $77^{\circ} 38^{\prime} 21^{\prime \prime}$ & Lenoir & Deep Run & 12.6 & Neuse River & 03020204 & 2 & 1964 & 1 & 1 \\
\hline 488 & 02092202 & Beaverdam Swamp near Pleasant Hill & $35^{\circ} 04^{\prime} 49^{\prime \prime}$ & $77^{\circ} 38^{\prime} 30^{\prime \prime}$ & Lenoir & Deep Run & 6.02 & Trent River & 03020204 & 2 & 1957 & 1 & 1 \\
\hline 489 & 02092210 & Trent River at Pleasant Hill & $35^{\circ} 04^{\prime} 03^{\prime \prime}$ & $77^{\circ} 35^{\prime} 25^{\prime \prime}$ & Jones & Deep Run & 27.5 & Neuse River & 03020204 & 2 & $1965-68,1970-71$ & 8 & 0 \\
\hline 490 & 02092230 & Joshua Creek near Combs Fork & $35^{\circ} 05^{\prime} 36^{\prime \prime}$ & $77^{\circ} 34^{\prime} 25^{\prime \prime}$ & Jones & Deep Run & 12.1 & Trent River & 03020204 & 2 & $1965-68,1970-71$ & 9 & 1 \\
\hline
\end{tabular}




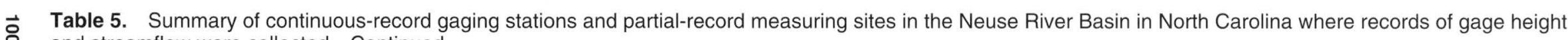
and streamflow were collected-Continued

$\left[\mathrm{mi}^{2}\right.$, square mile; SR, secondary road; N/A, not applicable; SEO, sewage effluent outfall. Sites shaded in gray indicate those sites for which low-flow characteristics have been developed. Period of record for continuous-record sites (site type 1) is shown in months and years; period of record for partial-record sites (site type 2) is shown in water years in which discharge measurements were made]

\begin{tabular}{|c|c|c|c|c|c|c|c|c|c|c|c|c|c|}
\hline \multirow{2}{*}{ 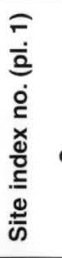 } & \multirow[t]{2}{*}{$\begin{array}{c}\text { USGS } \\
\text { downstream } \\
\text { order number }\end{array}$} & \multirow[t]{2}{*}{ Station name } & \multirow[t]{2}{*}{ Latitude } & \multirow[t]{2}{*}{ Longitude } & \multirow[t]{2}{*}{ County } & \multirow[t]{2}{*}{$\begin{array}{c}\text { USGS } \\
\text { topographic } \\
\text { quadrangle }\end{array}$} & \multirow[t]{2}{*}{$\begin{array}{c}\text { Drainage } \\
\text { area } \\
\left(\mathrm{mi}^{2}\right)\end{array}$} & \multirow[t]{2}{*}{$\begin{array}{c}\text { Tributary } \\
\text { to }\end{array}$} & \multirow[t]{2}{*}{$\begin{array}{l}\text { Hydrologic } \\
\text { unit } \\
\text { code }\end{array}$} & \multirow[t]{2}{*}{$\begin{array}{l} \pm \\
\sum \\
\stackrel{0}{2} \\
\text { के }\end{array}$} & \multirow[t]{2}{*}{ Period of record } & \multicolumn{2}{|c|}{$\begin{array}{l}\text { Number of } \\
\text { measure- } \\
\text { ments for } \\
\text { partial-record } \\
\text { sites }\end{array}$} \\
\hline & & & & & & & & & & & & Flow & $\begin{array}{l}\text { Zero } \\
\text { flow }\end{array}$ \\
\hline 491 & 02092262 & $\begin{array}{l}\text { Tuckahoe Swamp near Hargetts Cross- } \\
\text { roads }\end{array}$ & $34^{\circ} 59^{\prime} 40^{\prime \prime}$ & $77^{\circ} 40^{\prime} 00^{\prime \prime}$ & Jones & Potters Hill & 23.1 & Trent River & 03020204 & 2 & 1954,1957 & 2 & 2 \\
\hline 492 & 02092290 & Rattlesnake Branch near Comfort & $35^{\circ} 00^{\prime} 31^{\prime \prime}$ & $77^{\circ} 35^{\prime} 50^{\prime \prime}$ & Jones & Deep Run & $2.5^{\mathrm{a}}$ & $\begin{array}{l}\text { Tackahoe } \\
\text { Swamp }\end{array}$ & 03020204 & 2 & $1954,1957,1961-71$ & 14 & 2 \\
\hline 493 & 02092390 & Tuckahoe Creek near Pleasant Hill & $35^{\circ} 01^{\prime} 55^{\prime \prime}$ & $77^{\circ} 34^{\prime} 47^{\prime \prime}$ & Jones & Deep Run & 49.7 & Trent River & 03020204 & 2 & $1957,1966-68,1970-71$ & 6 & 0 \\
\hline 494 & 02092500 & Trent River near Trenton & $35^{\circ} 03^{\prime} 54^{\prime \prime}$ & $77^{\circ} 27^{\prime} 24^{\prime \prime}$ & Jones & $\begin{array}{l}\text { Phillips Cross- } \\
\text { roads }\end{array}$ & 168 & Neuse River & 03020204 & 1 & Jan. 1951 - Sept. 1996 & N/A & N/A \\
\hline 495 & 02092514 & $\begin{array}{l}\text { Big Chinquapin Branch near Phillips } \\
\text { Crossroads }\end{array}$ & $35^{\circ} 04^{\prime} 50^{\prime \prime}$ & $77^{\circ} 25^{\prime} 10^{\prime \prime}$ & Jones & $\begin{array}{l}\text { Phillips Cross- } \\
\quad \text { roads }\end{array}$ & $16^{\mathrm{a}}$ & Trent River & 03020204 & 2 & $1956-57$ & 2 & 0 \\
\hline 496 & 02092520 & Vine Swamp near Kinston & $35^{\circ} 09^{\prime} 29^{\prime \prime}$ & $77^{\circ} 33^{\prime} 16^{\prime \prime}$ & Lenoir & Rivermont & 6.30 & $\begin{array}{l}\text { Beaver } \\
\text { Creek }\end{array}$ & 03020204 & 2 & $1954,1957,1961-71$ & 13 & 2 \\
\hline 497 & 02092540 & Beaver Creek near Phillips Crossroads & $35^{\circ} 08^{\prime} 00^{\prime \prime}$ & $77^{\circ} 268^{\prime \prime}$ & Jones & Dover & $33^{\mathrm{a}}$ & Trent River & 03020204 & 2 & $1956-57,1960-68,1970$ & 20 & 0 \\
\hline 498 & 02092549 & Musselshell Creek near Trenton & $35^{\circ} 04^{\prime} 58^{\prime \prime}$ & $77^{\circ} 21^{\prime} 11^{\prime \prime}$ & Jones & Trenton & $9.7^{\mathrm{a}}$ & Trent River & 03020204 & 2 & $\begin{array}{l}1954,1957,1965-68 \\
1970-71\end{array}$ & 10 & 1 \\
\hline 499 & 0209254950 & Trent River at SR 1001 at Trenton & $35^{\circ} 04^{\prime} 05^{\prime \prime}$ & $77^{\circ} 20^{\prime} 55^{\prime \prime}$ & Jones & Trenton & $276^{\mathrm{a}}$ & Neuse River & 03020204 & 2 & 1974 & 1 & 0 \\
\hline 500 & 02092554 & Trent River at Pollocksville & $35^{\circ} 00^{\prime} 38^{\prime \prime}$ & $77^{\circ} 13^{\prime} 10^{\prime \prime}$ & Jones & Pollocksville & $370^{\mathrm{a}}$ & Neuse River & 03020204 & 1 & July 1996 - Sept. 1996 & N/A & N/A \\
\hline & & & & & & & & & & 2 & 1974 & 1 & 0 \\
\hline 501 & 0209256110 & $\begin{array}{l}\text { Wilson Creek at SR } 1278 \text { near Trent } \\
\text { Woods }\end{array}$ & $35^{\circ} 05^{\prime} 41^{\prime \prime}$ & $77^{\circ} 06^{\prime 22}$ & Craven & New Bern & 3.66 & Trent River & 03020204 & 2 & 1973-75 & 4 & 0 \\
\hline 502 & 02092569 & Brice Creek at SR 1100 at Croatan & $34^{\circ} 57^{\prime} 56^{\prime \prime}$ & $76^{\circ} 58^{\prime} 26^{\prime \prime}$ & Craven & Catfish Lake & $12^{\mathrm{a}}$ & Trent River & 03020204 & 2 & 1976 & 1 & 0 \\
\hline 503 & 02092571 & Brice Creek at Riverdale & $34^{\circ} 59^{\prime} 40^{\prime \prime}$ & $77^{\circ} 00^{\prime} 20^{\prime \prime}$ & Craven & Catfish Lake & $20^{\mathrm{a}}$ & Trent River & 03020204 & 2 & 1942,1957 & 2 & 2 \\
\hline 504 & 0209257120 & $\begin{array}{l}\text { W.P. Brice Creek below SR } 1101 \text { near } \\
\text { Riverdale }\end{array}$ & $34^{\circ} 58^{\prime} 09^{\prime \prime}$ & $77^{\circ} 02^{\prime} 55^{\prime \prime}$ & Craven & Catfish Lake & 11.2 & Brice Creek & 03020204 & 1 & Apr. 1986 - Sept. 1991 & N/A & N/A \\
\hline 505 & 02092590 & Upper Broad Creek near Olympia & $35^{\circ} 11^{\prime} 00^{\prime \prime}$ & $76^{\circ} 58^{\prime} 00^{\prime \prime}$ & Pamlico & Reelsboro & $21^{\mathrm{a}}$ & Neuse River & 03020204 & 2 & $1950-54,1956-59$ & 14 & 6 \\
\hline
\end{tabular}


Table 5. Summary of continuous-record gaging stations and partial-record measuring sites in the Neuse River Basin in North Carolina where records of gage height and streamflow were collected-Continued

$\left[\mathrm{mi}^{2}\right.$, square mile; SR, secondary road; N/A, not applicable; SEO, sewage effluent outfall. Sites shaded in gray indicate those sites for which low-flow characteristics have been developed. Period of record for continuous-record sites (site type 1) is shown in months and years; period of record for partial-record sites (site type 2) is shown in water years in which discharge measurements were made]

\begin{tabular}{|c|c|c|c|c|c|c|c|c|c|c|c|c|c|}
\hline 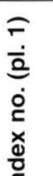 & $\begin{array}{c}\text { USGS } \\
\text { downstream } \\
\text { order number }\end{array}$ & Station name & Latitude & Longitude & County & $\begin{array}{c}\text { USGS } \\
\text { topographic } \\
\text { quadrangle }\end{array}$ & $\begin{array}{c}\text { Drainage } \\
\text { area } \\
\left(\mathrm{mi}^{2}\right)\end{array}$ & $\begin{array}{l}\text { Tributary } \\
\text { to }\end{array}$ & $\begin{array}{c}\text { Hydrologic } \\
\text { unit } \\
\text { code }\end{array}$ & 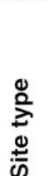 & Period of record & $\begin{array}{r}\text { Numb } \\
\text { mea } \\
\text { men } \\
\text { partial } \\
\text { sit }\end{array}$ & $\begin{array}{l}\text { er of } \\
\text { ure- } \\
\text { s for } \\
\text { record } \\
\text { es }\end{array}$ \\
\hline 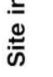 & & & & & & & & & & & & Flow & $\begin{array}{l}\text { Zero } \\
\text { flow }\end{array}$ \\
\hline 506 & 02092620 & $\begin{array}{l}\text { Upper Broad Creek tributary near Grants- } \\
\text { boro }\end{array}$ & $35^{\circ} 08^{\prime} 06^{\prime \prime}$ & $76^{\circ} 56^{\prime} 31^{\prime \prime}$ & Pamlico & Reelsboro & 3.0 & $\begin{array}{l}\text { Upper } \\
\text { Broad } \\
\text { Creek }\end{array}$ & 03020204 & 2 & $1957-58,1961-73$ & 15 & 1 \\
\hline 507 & 02092626 & Goose Creek near Scotts Store & $35^{\circ} 06^{\prime} 12^{\prime \prime}$ & $76^{\circ} 53^{\prime} 33^{\prime \prime}$ & Pamlico & $\begin{array}{l}\text { Upper Broad } \\
\text { Creek }\end{array}$ & $25^{\mathrm{a}}$ & Neuse River & 03020204 & 2 & 1957 & 1 & 1 \\
\hline 508 & 02092636 & $\begin{array}{l}\text { East Prong Slocum Creek near Cherry } \\
\text { Point }\end{array}$ & $34^{\circ} 52^{\prime} 57^{\prime \prime}$ & $76^{\circ} 54^{\prime} 32^{\prime \prime}$ & Craven & Havelock & 8.31 & $\begin{array}{l}\text { Slocum } \\
\text { Creek }\end{array}$ & 03020204 & 2 & 1973 & 1 & 0 \\
\hline
\end{tabular}

${ }^{a}$ Approximate drainage area.

${ }^{\mathrm{b}}$ Discharge measurements obtained after this water year made in conjunction with water-quality sampling at site.

${ }^{\mathrm{c}}$ Discharge measurements made in conjunction with water-quality sampling at site.

${ }^{\mathrm{d}}$ Drainage area revised from $55.2 \mathrm{mi}^{2}$ when site and road were relocated upstream from a tributary draining to original location. Previous drainage area used in low-flow analyses and is thus shown for this site in tables 7 and 8 . 


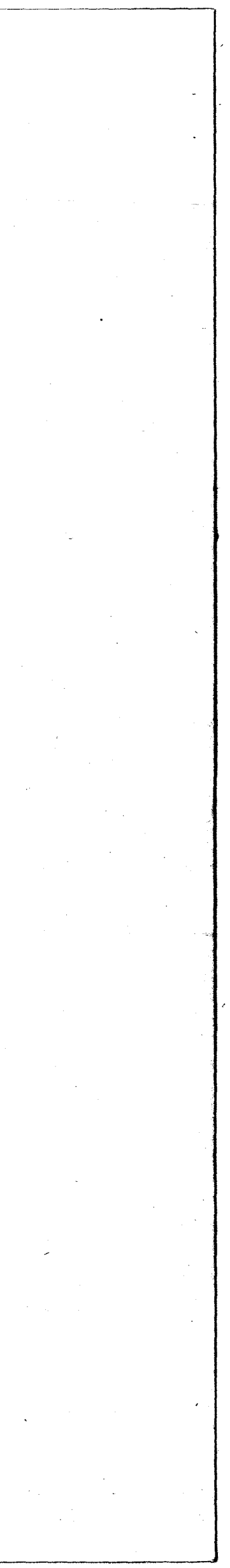




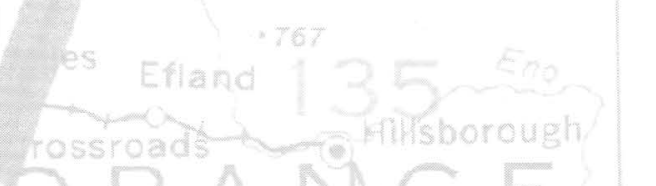

SRA $A N G E$ Ene

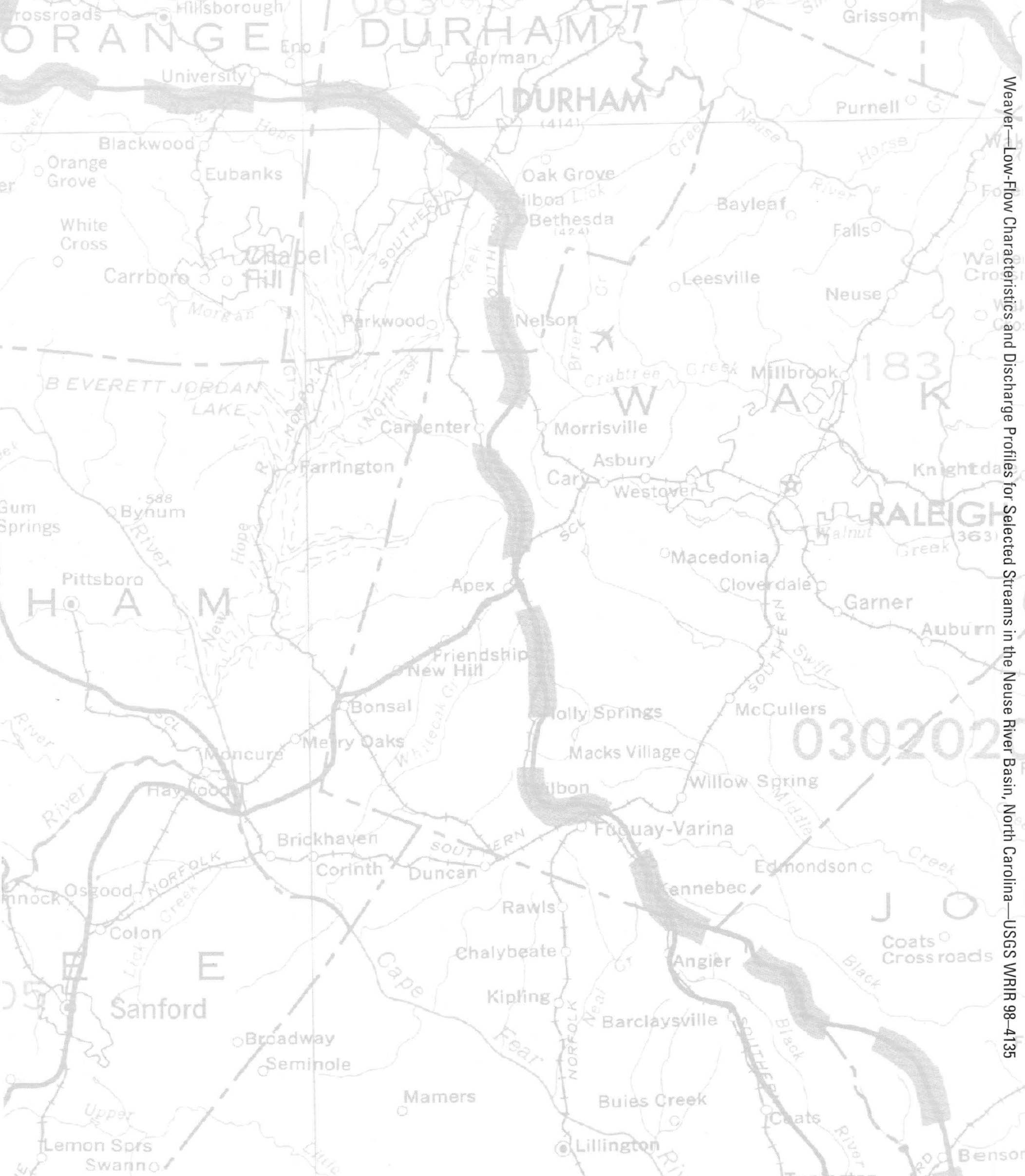

